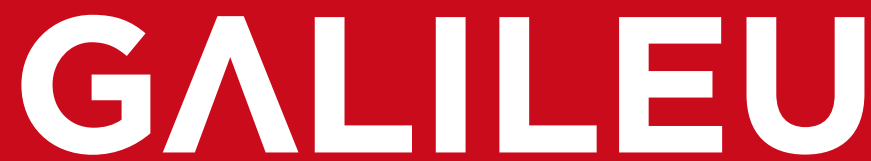

REVISTA

DE DIREITO

E ECONOMIA 


\section{GALILEU - REVISTA DE DIREITO E ECONOMIA}

VOLUME XIX · Issue $2 \cdot 1^{\text {st }}$ July $-31^{\text {st }}$ December 2018

Semiannual Publication. Scientific Journal of the Ratio Legis - Centro de Investigação e Desenvolvimento em Ciências Jurídicas from the Universidade Autónoma de Lisboa - Luís de Camões.

\section{DIRECTORY}

Repositório Científico de Acesso Aberto de Portugal (RCAAP).

\section{DATABASES}

Repositório Institucional da Universidade Autónoma de Lisboa (Camões).

\section{GALILEU - REVISTA DE DIREITO E ECONOMIA}

VOLUME XIX · Fascículo 2 - 1 de julho-31 de dezembro 2018

Publicação semestral. Revista Científica do Ratio Legis - Centro de Investigação e Desenvolvimento em Ciências Jurídicas da Universidade Autónoma de Lisboa - Luís de Camões.

DIRETÓRIOS

Repositório Científico de Acesso Aberto de Portugal (RCAAP).

BASE DE DADOS

Repositório Institucional da Universidade Autónoma de Lisboa (Camões). 
PUBLISHING INSTITUTION INSTITUIÇÃO EDITORA

CEU - Cooperativa de Ensino Universitário, C.R.L.

EDIUAL - Universidade Autónoma Editora

Rua de Santa Marta, 47 - 1150-293 Lisboa

PHONE TELEFONE +351 $213177667 \cdot$ e-mail: galileu@autonoma.pt

Este trabalho é financiado por Fundos Nacionais através da FCT - Fundação para a Ciência e a Tecnologia no âmbito do projecto Ref.a: UID/DIR/04441/2016.

This work was funded by national funds through FCT - Fundação para a Ciência e a Tecnologia - as part the project Ratio Legis - Ref..: UID/DIR/04441/2016.

\section{E-ISSN 2184-1845}

DOI https://doi.org/10.26619/2184-1845.XIX.2

TITLE TÍTULO Galileu - Revista de Direito e Economia

SITE http://journals.ual.pt/galileu/

REgISTRATION Status Under Publishing SITUAÇÃo de REgISTO Em Publicação

FORMAT SUPORTE Online

REGISTRATION ERC Notation INSCRIÇÃo Anotada na ERC

PERIODICITY Semiannual PERIODICIDADE Semestral

EDITOR IN CHIEF DIRETOR EDITOR Paulo Costa

ASSISTANT DIRECTORS DIRETORES ADJUNTOS Ruben Bahamonde, Davide Argiolas

SCIENTIFIC EDITOR EDITOR CIENTÍFICO RATIO LEGIS 
EDITOR IN CHIEF DIRETOR EDITOR

Paulo Nogueira da Costa Universidade Autónoma de Lisboa, Portugal pcosta@ual.pt

\section{ASSISTANT DIRECTORS DIRETORES ADJUNTOS}

\begin{tabular}{lll}
\hline Davide Argiolas & Universidade Autónoma de Lisboa, Portugal & argiolasdavide@gmail.com \\
\hline Ruben Bahamonde Delgado & Universidade Autónoma de Lisboa, Portugal & rbahamonde@ual.pt \\
\hline
\end{tabular}

\section{EDITORIAL BOARD CONSELHO EDITORIAL}

\begin{tabular}{lll}
\hline Aloísio Cristóvão dos Santos Júnior & Centro Universitário Estácio da Bahia, Brasil & acristovamjr@gmail.com \\
\hline António Carlos dos Santos & Universidade Europeia, Portugal & acsantos@iseg.utl.pt \\
\hline Constança Urbano de Sousa & Universidade Autónoma de Lisboa, Portugal & mconstanca@autonoma.pt \\
\hline Fernando Cachafeiro Garcia & Universidade da Corunha, Espanha & fernando.cachafeiro@ude.es \\
\hline Francisco Hernández & $\begin{array}{l}\text { Universidade de Santiago de Compostela, } \\
\text { Espanha }\end{array}$ & $\begin{array}{l}\text { francisco.hernandez.rodriguez@ } \\
\text { consellogalegodacompetencia.es }\end{array}$ \\
\hline João Nogueira de Almeida & Universidade de Coimbra, Portugal & jjna@fd.uc.pt \\
\hline Julio Garcia Camiñas & Universidade da Corunha, Espanha & jgc@udc.es \\
\hline Manuel António Pita & $\begin{array}{l}\text { Instituto Superior das Ciências do Trabalho e } \\
\text { do Emprego, Instituto Universitário, Portugal }\end{array}$ & manuel.pita@iscte-iul.pt \\
\hline Paulo Nogueira da Costa & Universidade Autónoma de Lisboa, Portugal & pcosta@ual.pt \\
\hline Pedro Trovão do Rosário & Universidade Autónoma de Lisboa, Portugal & prosario@autonoma.pt \\
\hline Roberto Mazzola & $\begin{array}{l}\text { Università degli Studi del Piemonte } \\
\text { Orientale - Amedeo Avogadro, Itália; }\end{array}$ & rmazzola961@gmail.com \\
\hline Teófilo Ârea Leão Júnior & $\begin{array}{l}\text { Università di Torino, Itália } \\
\text { Marilia, Brasil }\end{array}$ & $\begin{array}{l}\text { Universidade Estadual do Norte do Paraná, } \\
\text { Brasil }\end{array}$ \\
\hline Valter Santin & $\begin{array}{l}\text { Instituto Superior das Ciências do Trabalho e } \\
\text { do Emprego, Instituto Universitário, Portugal }\end{array}$ & vbrguimaraes@net.sapo.pt \\
\hline Vasco Branco Guimarães & teofiloleaojr@gmail.com \\
\hline
\end{tabular}




\section{Índice Index}

6 Editorial

PAULO NOGUEIRA DA COSTA

7 A colocação em rede electrónica digital ( $W w w)$ de obras intelectuais e de outros conteúdos protegidos alheios Putting intellectual property and other people's protected contents in the digital network (WWw)

ALBERTO DE SÁ E MELLO

28 Justiça \& Cidadania: Aportações de Direito \& Arte Justice \& Citizenship: Contributions from Law \& the Arts

PAULO FERREIRA DA CUNHA

49 A utilização de novas tecnologias no âmbito da investigação criminal e as suas limitações legais: a interceptação de comunicações em massa e os softwares de espionagem The use of new technologies in criminal investigations and their legal limitations: interception of mass communications and espionage software EDUARDO BOLSONI RIBOLI

78 O Princípio da Lealdade - Provas Obtidas por Meios Proibidos nos Tribunais Internacionais The Principle of Loyalty - Evidence Obtained in the International Courts Using Prohibited Methods MARIA JOÃO SIMÕES ESCUDEIRO

100 Desafiar Mamon: O Estado das Contas Públicas Challenging Mammon: The State of Public Accounts JOSÉ EMANUEL MATOS TORRES

131 The structuring principles of Mediation in Portugal RUBEN BAHAMONDE

\section{COMENTÁRIOS DE LEGISLAÇÃO E JURISPRUDÊNCIA COMMENTS ON LEGISLATION AND JURISPRUDENCE}

155 Comentário à jurisprudência do Superior Tribunal Federal brasileiro sobre início de cumprimento da pena após acórdão condenatório em 2.. instância (Habeas Corpus n.ำ 126.292/SP) Comment on the jurisprudence of the Brazilian Supreme Federal Court on the start of the sentence following conviction in the 2 nd instance (Habeas Corpus No. 126.292/SP)

MAXWELL SILVA LAPA

160 Comentário ao Acórdão do Supremo Tribunal de Justiça n.ำ 533/16.7PBSTR.E1.S1 de 19/04/2018 Comment on the Ruling of the Supreme Court of Justice No. 533/16.7PBSTR.E1.S1 of $19 / 04 / 2018$

VANESSA DE BRITO SEQUEIRA

ALFREDO ANDRADE SANTOS

\section{RECENSÕES}

REVIEWS

166 "Os desafios do direito do século XXI" "The challenges of law in the $21^{\text {st }}$ century"

168 "Novos estudos sobre liberdade religiosa, risco e segurança no século XXI" "New studies on religious freedom, risk and security in the $21^{\text {st }}$ century" 


\section{Editorial}

Continuamos a nossa missão com a publicação deste segundo número do Volume XIX da revista de Direito e Economia GALILEU, que resulta do compromisso e dedicação de toda a equipa que integra e/ou colabora com o Centro de Investigação Ratio Legis. A difusão para a nossa comunidade da produção científica de investigadores de referência nacional e internacional continua a ser o cunho desta publicação, não esquecendo, porém, aqueles que iniciam a sua caminhada no universo da investigação científica, produzindo textos de grande relevância, como os que integram o presente número.

A quantidade de contributos recebidos exigiu, como é hábito, uma necessária e criteriosa seleção para dotar a publicação do maior grau de pluralidade, atualidade e diversidade possivel, sem significar tal seleção um menosprezo por outros trabalhos que, preenchendo altos padrões de qualidade, não lograram ser publicados com o presente número.

O Diretor da Galileu Ruben Bahamonde Delgado 


\title{
A colocação em rede electrónica digital (www) de obras intelectuais e de outros conteúdos protegidos alheios ${ }^{1}$
}

\author{
Putting intellectual property and other people's protected \\ contents in the digital network (www)
}

\author{
ALBERTO DE SÁ E MELLO² \\ GALILEU - REVISTA DE DIREITO E ECONOMIA - e-ISSN 2184-1845 \\ Volume XIX $\cdot 1^{\text {st }}$ July Julho $-31^{\text {TH }}$ December Dezembro $2018 \cdot$ pp. 7-27 \\ DOI: https://doi.org/10.26619/2184-1845.XIX.2.2 \\ Submitted on October $28^{\text {th }}, 2018$. Accepted on November 11 $11^{\text {th }}, 2018$ \\ Submetido em 28 de Outubro, 2018 · Aceite a 11 de Novembro, 2018
}

ABSTRACT The intellectual, literary or artistic works and the performances of artists, as well as all types of texts and data, if in digital format, can be made available to the public on the Internet. This paper seeks to assess the extent to which access, including for private use, to such protected immaterial contents may harm the exclusive rights of copyright owners, related artists' rights and the sui generis rights of database producers over them.

KEYWORDS Internet. Intellectual works and other protected content. Links - the Svensson case. Napster and private use. Spotify. Netflix. Multi-territorial licenses of music works' rights for online use in the domestic market.

1 Escrito baseado em lição proferida pelo autor, em Julho de 2017, no Curso de Verão em Direito da Propriedade Intelectual: O Estado das questões em 2017, organizado pela Associação Portuguesa de Direito Intelectual, na Faculdade de Direito da Universidade de Lisboa. Este escrito é adaptação, com muitas actualizações, de outro, de direito comparado, publicado no Brasil, na Revista Fórum de Direito Civil, ano 7 - n. ${ }^{\circ}$ 17, Belo Horizonte, Brasil, 2018.

2 Doutor em Direito. Professor catedrático convidado na Faculdade de Direito da Universidade Lusófona de Humanidades e Tecnologias (ULHT - Lisboa). Advogado. albsamello@netcabo.pt. 


\section{A Internet como veículo de utilização de obras e outros conteúdos protegidos}

É sabido que a Internet permite, mediante prévia digitalização, a transmissão de todo o tipo de conteúdos imateriais, desde as obras intelectuais e prestações artísticas, às bases de dados informativas (nomeadamente as noticiosas).

Defrontaram-se - e defrontam-se ainda - duas correntes sobre o grau de juridificação desejável para a Internet: as que defendem a Internet como espaço de livre circulação de conteúdos, onde, supostamente em fidelidade à ideia inicial, transitam sem peia todas as ideias de todos os tipos, sem censura e gratuitamente; e as que sustentam a juridificação da net (www) pela aplicação das regras já existentes para a utilização off-line dos bens intelectuais e outros conteúdos imateriais protegidos, que foram instituídas já na previsão da superveniência de "novos meios de exploração" (cfr. art. 68.\%1 CDA3). A Directiva 2001/29/ $\mathrm{CE}$, que pretendeu regular os direitos de autor na sociedade da informação ${ }^{4}$, confirmou a opção, já antes desenhada, pela segunda corrente. Veremos em que termos.

\section{Os bens protegidos na Internet}

Vários bens juridicamente protegidos podem ser veiculados na Internet. Veremos que essa transmissão, dita on-line e que é verdadeiramente colocação à disposição do público em rede $^{5}$, mobiliza todas as faculdades de direito de autor e de direitos conexos, bem como o direito sui generis do fabricante das bases de dados.

\subsection{Obras literárias, artísticas e audiovisuais}

I - As obras literárias (escritos), artísticas (pinturas, gravuras, esculturas) ou audiovisuais (cinematográficas, videográficas) são passíveis de transmissão em rede digital global $(w w w)$.

3 CDA - Código do Direito de Autor e dos Direitos Conexos de Portugal, aprovado pelo Decreto-lei n. ${ }^{\circ}$ 63/85, de 14-3, sucessivamente alterado até à Lei n. ${ }^{0} 100 / 2017$, de 23-8.

4 Dir. Soc. Inf. - Directiva 2001/29/CE, de 22-5-2001, relativa à harmonização de certos aspectos do direito de autor e dos direitos conexos na sociedade da informação, na União Europeia (então CEE).

5 A telecomunicação (dita "transmissão on-line") na rede www não se faz "em linha", mas em rede, como é sabido. Em explicação e desenvolvimento desta ideia, pode cfr. o nosso A telecomunicação electrónica em rede de obras intelectuais na "sociedade da informação" - a Directriz 2001/29/CE e a sua transposição em Portugal pela Lei n. ${ }^{\circ}$ 50/2204, in "Direito da Sociedade da Informação" (coligação de obras coordenada pelo Professor Doutor José de Oliveira Ascensão) - Vol. VII, Coimbra, 2008. 
Na verdade, a divulgação de uma obra inédita na rede, sem autorização do seu criador, representa violação do direito pessoal de divulgação ${ }^{6}$. A colocação de uma obra já antes divulgada à disposição dos usuários da rede ${ }^{7}$, sem autorização do titular do direito de autor, é violação do exclusivo patrimonial do autor de comunicação pública das suas obras (cfr. art. 68. $\%$-j) CDA). O facto de a quebra do ineditismo (violação do direito pessoal) ou de a transmissão on-line se dar na net não prejudica menos os interesses do autor, que assim vê a sua criação desvendada sem (ou contra) a sua vontade, ou usurpado por terceiros (cfr. art. 195.\%1 CDA) o seu exclusivo de exploração económica, por qualquer meio, da sua obra.

II - Os multimédia - que uns designam meros produtos, mas que podem combinar criativamente também obras intelectuais (textos, imagens animadas ou não, gráficos, programas de computador, como nos videojogos) e assim qualificar-se como verdadeiras obras intelectuais ${ }^{8}$ - também são passíveis de utilização on-line.

Veremos que uma proposta de Directiva da União Europeia actualmente em discussão pública ${ }^{9}$ contém até disposição específica que prevê que a assistência nos contratos de licenciamento da exploração de obras audiovisuais em plataformas de vídeo a pedido seja entregue a um organismo independente.

\subsection{A utilização de marcas na Internet}

A Directiva 2004/48/CE, do Parlamento Europeu e do Conselho, de 29-4-2004, relativa ao respeito dos direitos de propriedade intelectual, estabelece, no seu art..$^{\circ}$, que "engloba os direitos de propriedade industrial". A Directiva 2000/31, do Parlamento Europeu e do Conselho, de 8-6-200o, relativa especialmente ao comércio electrónico, compreende expressamente, entre as "comunicações comerciais", as formas de comunicação que "promovam a imagem da sociedade", o que refere às marcas ou logótipos. A Directiva 2015/2436, de 16-122015, em matéria de marcas, reserva (art. 10. ${ }^{\circ}$ ) ao seu titular a "utilização da marca na vida

6 O direito de divulgação (ou ao inédito) de obra intelectual é um direito pessoal do autor, que reserva, como exclusiva deste, a faculdade de decidir se, quando e como divulga (ou não) a sua obra. Em desenvolvimento deste tema, pode cfr. os nossos $O$ direito pessoal de autor no ordenamento jurídico português, Lisboa, 1989 e O direito pessoal (dito «moral») de autor - nos ordenamentos jurídicos português e espanhol, in Revista de Direito Intelectual, Lisboa, n. ${ }^{\circ} 1-2017$.

7 Distinguimos o uso de uma obra intelectual ou de uma prestação artística, mediante o acesso a elas na net ou fora dela, da sua utilização. Ao utilizar uma obra ou uma prestação artística, aquele que o faz explora-as economicamente, utiliza-as patrimonialmente segundo uma das faculdades exclusivas previstas na lei (de reprodução, de transformação, de distribuição, de colocação em rede à disposição do público). Ao usá-las, o usuário limita-se a desfrutá-las intelectualmente (contemplando uma pintura, lendo um livro, consultando um sítio na net), sem que necessariamente as explore economicamente, utilizando-as patrimonialmente.

8 Sobre este tema, pode cfr. o nosso Os multimedia - regime jurídico", in "Direito da Sociedade da Informação" (coligação de obras coordenada pelo Professor Doutor José de Oliveira Ascensão) - Vol. II, Coimbra, 2001.

9 Proposta de Directiva $\operatorname{COM}(2016)$ 593, de 14-9-2016, segundo texto aprovado pelo Parlamento Europeu em 14-92018, a cuja análise dedicaremos o n. ${ }^{\circ} 4$ deste escrito. 
comercial" sem distinguir utilizações tradicionais da promoção ou divulgação on-line, na Internet, dos produtos ou serviços com marca registada.

É inquestionável que a utilização na net da marca como sinal distintivo de comércio, indústria ou serviço depende de autorização do seu titular.

\subsection{As bases de dados}

As bases de dados - colectâneas de obras ou outros elementos (informações, por exemplo) dispostos de modo metódico, individualmente acessiveis - são objecto de protecção por direito de autor, como obras-base de dados, desde que a organização ou escolha dos elementos seja criativa, e por direito sui generis do fabricante / produtor, desde que tenha havido investimento substancial na sua produção. ${ }^{10}$

As bases de dados electrónicas, acessíveis on-line, também reservam aos respectivos titulares a autorização para "acesso individual por meios electrónicos" (art. 1. \% $/ 2$ do Decreto-lei 122/2000), obviamente incluindo o acesso em rede pela Internet.

\subsection{As prestações artísticas}

Os artistas, intérpretes ou executantes (actores, cantores, músicos, bailarinos) têm o poder exclusivo de autorizar ou impedir a radiodifusão e comunicação ao público em geral, a fixação, a reprodução e, principalmente, a colocação à disposição do público (na rede) das suas prestações artísticas, por quaisquer meios (art. $178 .^{\circ} \mathrm{CDA}$ ), incluindo naturalmente pela Internet.

\subsection{Os fonogramas e os videogramas}

O produtor de fono/videogramas (registo que fixa em suporte material sons ou imagens, ainda que não protegidos) tem o direito (conexo ao direito de autor) exclusivo de autorizar a distribuição de cópias, a difusão (incluindo a radiodifusão), a execução pública ou a colocação à disposição do público (na www) destes objectos, por qualquer meio, incluindo pela Internet (art. $\left.184 .^{\circ} \mathrm{CDA}\right)$.

\subsection{Os programas televisivos e radiofónicos radiodifundidos}

Os titulares dos organismos de radiodifusão (televisões, rádios) gozam do direito (conexo ao direito de autor) de autorizar ou proibir a retransmissão ou colocação à disposição do

10 Em desenvolvimento deste tema, pode cfr. o nosso Tutela jurídica das bases de dados (a transposição da directriz 96/9/CE), in "Direito da Sociedade da Informação" (coligação de obras coordenada pelo Professor Doutor José de Oliveira Ascensão) - Vol. I, Coimbra, 1999. 
público em rede-www das suas emissões (art. 187. ${ }^{\circ} \mathrm{CDA}$ ). Está incluída neste exclusivo, evidentemente, a transmissão on-line dos programas televisivos ou radiofónicos (streaming ${ }^{11}$ ).

\subsection{Os espectáculos}

I - Advogamos ser reservado ao empresário o direito exclusivo de autorizar ou proibir a exploração económica, incluindo a transmissão on-line, dos espectáculos que organiza e promove empresarialmente. ${ }^{12}$

A transmissão on-line "ao vivo" ou o download desses espectáculos, quando sejam colocados em rede sons ou imagens dos mesmos, viola o direito daquele.

II - Muito recentemente, a Dir.Merc.Un.Dig.* prevê que os Estados-membros devem conceder aos organizadores de eventos desportivos os direitos exclusivos de reprodução e de colocação à disposição do público (na Internet), bem como de fixação de prestações artísticas. Não estão incluídas as outras modalidades de comunicação ao público, por fio ou sem fio, nomeadamente por radiodifusão, já que a Directiva é expressa na remissão apenas para o n. ${ }^{\circ} 2$ do art. $3 .{ }^{\circ}$ da Directiva 2001/29/CE (Dir.Soc.Inf. ${ }^{*}$ ), afastando a referência ao n. ${ }^{\circ}$ 1, onde esta está consagrada.

Esta inovadora previsão dá, finalmente, foro de cidadania aos organizadores de espectáculos desportivos, empresários a quem se reconhece um direito conexo.

Como não reconhecemos aos agentes que participam em eventos desportivos (atletas, treinadores, árbitros) qualquer direito conexo sobre as suas prestações, posto que não interpretam quaisquer obras intelectuais, temos de admitir que deparamos com um direito empresarial, conexo aos direitos de autor, não conexionado com qualquer outro direito intelectual (seja direito de autor ou direito conexo).

Isto significa que o direito do organizador do evento, um empresário, ainda que tenha natureza associativa ou pública, passa a beneficiar de um direito exclusivo de explorar economicamente um espectáculo de entretenimento e celebração desportiva não associado a

11 O streaming é uma forma de distribuição digital de conteúdos multimedia na Internet. Estes conteúdos não são, por este meio, armazenados pelo usuário no seu próprio computador. O live streaming permite o visionamento ao vivo, através da net, de programas que são transmitidos por radiodifusão, cabo ou satélite. Serviços como o Netflix e o Spotify, que não obrigam ao upload de dados, transmitem estes conteúdos.

Embora o streaming não implique o descarregamento e armazenamento dos conteúdos no computador dos usuários, considera-se maioritariamente que o streaming de obras ou de outros conteúdos protegidos requer autorização e justifica remuneração ao autor (por todos, cfr. aresto do Superior Tribunal de Justiça do Brasil - 2 . $^{\text {a }}$ Sec. REsp. 1559264/RJ, Relator Min. Ricardo Villas Bôas Cuevo, julgado em 8/2/2017).

12 Sobre a natureza e conteúdo deste direito ao espectáculo, cfr. o nosso Filmagem de espectáculos desportivos e «direito de arena», in "Creaciones Audiovisuales y Propiedad Intelectual" (coligação de obras coordenada pelo Professor Doutor Carlos Rogel Vide, Catedrático da Universidad Complutense de Madrid), Madrid, 2001. 
qualquer criação ou prestação literária ou artística (com o sentido que "artístico" tem em direito intelectual). ${ }^{13}$ Este aspecto tem tanto maior importância quanto é verificável que este direito tem conteúdo e denominação idênticos aos dos verdadeiros direitos de autor.

Temos, pois, mais um direito empresarial com o regime dos direitos intelectuais, cujo objecto é obviamente passível de colocação on-line.

\subsection{As "obras geradas por computador"}

A lei do Reino Unido, por exemplo, consagra o "copyright" relativamente às "obras geradas por computador sem intervenção humana" (art. 178(b) UKCDPA ${ }^{14}$ ). O titular do mesmo é a pessoa que faz os "arrangements" necessários à criação da obra em questão.

Defendemos que os computadores não são "autores" de quaisquer obras ${ }^{15}$, mas a subsistência deste "copyright" investe o seu titular no direito exclusivo também de colocação à disposição do público (em rede) destas "obras".

\subsection{Os bens informáticos}

Os próprios programas de computador (além das já assinaladas bases de dados electrónicas) são objecto de direito de autor, análogo ao das obras literárias (art. 3.²/2 do Decreto-lei n. $\left.{ }^{\circ} 252 / 94\right)$.

Como verdadeiras obras intelectuais, os programas de computador são objecto de exclusivo de exploração económica. A utilização on-line destes é também proibida sem autorização do titular do direito exclusivo, apesar de a mesma não obrigar a revelar o código-fonte do programa.

\section{As faculdades de direito de autor e direitos conexos mobilizadas}

A colocação à disposição do público em rede electrónica digital global (www) de obras intelectuais e de outros conteúdos protegidos alheios pode bulir com quase todas as faculdades jusautorais exclusivas. Vejamos em que termos.

13 Mesmo o direito sui generis do fabricante da base de dados tem associado, embora não necessariamente, algo que é classificado como obra intelectual, a obra-base de dados.

14 UKCDPA - lei de autor do Reino Unido da Grã-Bretanha e Irlanda do Norte ("UK Copyright, Designs and Patents Act”), de 15-11-1988, com última alteração pela S.I. 2006/1028).

15 Em desenvolvimento desta ideia, pode cfr. o nosso Manual de Direito de Autor e Direitos Conexos, 2..$^{\mathrm{a}}$ ed., 2016, n. $^{\circ} 10$. 


\subsection{Faculdade (ou direito) de reprodução}

A colocação de uma obra à disposição do público na net não implica, por si só, a sua reprodução, que é a multiplicação da obra em exemplares tangíveis, ainda que digitais. No entanto, aquela colocação à disposição do público é, muitas vezes, acto preparatório (ou, pelo menos, antecedente necessário) desta reprodução, visto que podem "descarregar-se" permanentemente os ficheiros transmitidos on-line, incluindo os que contenham obras ou outros conteúdos protegidos, e já que a reprodução "por qualquer meio" de obras (art. 68. ²-i) CDA) ou de prestações artísticas (art. 178. \%1-c) CDA) é reservada.

Também a digitalização de obra ou outro conteúdo protegido, passo prévio necessário à transmissão on-line, está reservada: o art. 68.\%/2-d) CDA atribui em exclusivo ao autor o direito de "fixação em qualquer aparelho destinado à transmissão" de obras na net, o que obviamente inclui o computador em cujo disco se gravem.

Mas não são só as obras e as prestações artísticas que não podem reproduzir-se. $\mathrm{O}$ direito sui generis do fabricante das bases de dados implica que a informação contida nessa base não possa ser "extraída" (o seu conteúdo transferido para outro suporte) sem o consentimento do titular (art. 12. $/ 2$-a) do Decreto-lei 122/2000, de Portugal). De igual modo, a obra-base de dados, que vimos ser objecto de direito de autor, só pode ser reproduzida com autorização do seu autor (art. 7.\%/1-a) do mesmo Decreto-lei).

\subsubsection{As reproduções meramente tecnológicas}

Durante algum tempo, pretendeu-se que a fixação temporária e transitória de obras e outros conteúdos protegidos na memória RAM dos computadores, passo necessário às transmissões on-line e à sua mera visualização em ecrã de computadores, constituiria reprodução reservada, obrigando a autorização e remuneração ao titular do direito. Não é assim. ${ }^{16}$

A Directiva 2001/29 (art. 5. ${ }^{\circ} / 1$ ) - transposta em Portugal pela Lei n. ${ }^{0}$ 50/2004 (art. 75. $\% 1$ CDA) - exceptua expressamente do exclusivo jusautoral as "reproduções temporárias que sejam transitórias, episódicas ou acessórias, que constituam parte de um processo tecnológico e cujo único objectivo seja permitir uma transmissão numa rede [...], incluindo os actos que permitam a navegação em rede e a armazenagem temporária".

16 Sobre este tema, cfr. o nosso A telecomunicação electrónica em rede de obras intelectuais na "sociedade da informação" - a Directriz 2001/29/CE e a sua transposição em Portugal pela lei n. ${ }^{\circ}$ 50/2204, cit.. 


\subsection{Faculdade (ou direito) de distribuição}

I - A lei (art. 68. \% /2-f) CDA) consagra o direito exclusivo de distribuição do original ou cópias de obras, nomeadamente pela venda, aluguer ou comodato. A lei refere-se ao original ou cópias em que a(s) obra(s) esteja(m) fixada(s).

Evidentemente que a venda, aluguer ou comodato da obra podem operar on-line ("por qualquer forma"), considerando-se que os "exemplares da obra" se podem fixar, após transmissão on-line, em suporte digital.

II - O direito de distribuição esgota-se com a primeira venda lícita de exemplar da obra (art. 68.\%/5 CDA). Naturalmente, deve considerar-se que este direito se esgota também com a primeira venda dos direitos de transmissão on-line.

\subsection{Faculdade (ou direito) de comunicação ao público, incluindo a colocação à disposição do público em rede de obra ou outro conteúdo protegido}

Esta faculdade, acrescentada expressamente ao elenco jusautoral pela Directiva 2001/29, é a própria essência da transmissão e acesso a conteúdos protegidos na Internet. Distingue-a da comunicação ao público em geral, o facto de, nesta, as obras serem feitas acessíveis ao público num momento só, escolhido pelo que as comunica, por exemplo pela radiodifusão; enquanto naquela (colocação à disposição do público), a obra ou prestação artística são tornadas acessíveis em rede no local e momento escolhidos pela pessoa que lhes acede (art. 68. $\%$ - $-\mathrm{j}$ ) e $178 .^{\circ} / 1-\mathrm{d}$ ) CDA).

\subsubsection{A visualização em ecrã de conteúdos colocados à disposição do público}

Pretender que a mera visualização em ecrã de obras ou outros conteúdos, licitamente transmitidos on-line e acessíveis em rede, constitui uma reprodução da obra e, como tal, um acto dependente de autorização do autor ou outro titular de direito autoral exclusivo é o mesmo que admitir que cada leitura/consulta de um livro licitamente adquirido justificaria o consentimento do autor. Trata-se de mera recepção de conteúdo transmitido que, desde que a colocação à disposição do público seja lícita, não justifica/requer uma autorização autónoma.

\subsection{Dos hipernexos (hiperligações)}

Os hipernexos (ou hiperligações) são "links" contidos numa determinada página/sítio da web, que pode conter ou não conteúdos protegidos, a outras páginas/sítios, que também podem conter conteúdos protegidos autónomos/diferentes. 
Coloca-se o problema de saber se este "transporte" de um sítio virtual para outro deve ser acto reservado, visto que permite o acesso a conteúdos cuja utilização não foi autorizada no âmbito do consentimento do acesso ao sítio primário e à utilização das obras nele contidas. Na verdade, pode perguntar-se se é ou não livre o acesso a páginas "secundárias", acessíveis ao usuário da net mediante hiperligações, quando estas contiverem conteúdos protegidos (mesmo que esses conteúdos sejam de utilização livre ou autorizada previamente).

\subsubsection{A situação após o caso Svensson}

I - A questão das hiperligações foi objecto de uma decisão do Tribunal de Justiça da União Europeia (TJUE) (Acórdão de 13-2-2014, caso Svensson et alia vs. Retriever Sverige AB - C-466/12).

Os Recorrentes (Svensson) demandaram a R. Sverige e alegaram que esta violou o direito exclusivo de colocação à disposição do público por fornecer listas de ligações Internet contendo obras protegidas; era consensual entre as Partes que essas obras - artigos de jornal - eram de livre acesso no sítio original, ou seja, se se acedesse às obras directamente no sítio onde estavam localizadas, e não via link, o acesso estava autorizado. A R. Sverige alegava que não transmitia obra protegida, apenas redireccionava clientes para outro sítio/página.

O TJUE considerou que o art. $3 . \%$ da Directiva 2001/29 inclui dois elementos no conceito de comunicação ao público: "acto de comunicação" e "público novo".

Sobre o primeiro, "acto de comunicação", considera o Tribunal que deve ser entendido de forma lata (ex Acórdão TJUE, de 4-10-2011, Football Association Premier League C- 403/08 e C-429/08), "de modo a garantir um nível elevado de protecção aos titulares dos direitos de autor". Considera-se que: a) "o facto de fornecer, num sítio da Internet, hiperligações para obras protegidas publicadas, sem qualquer restrição de acesso, noutro sítio da Internet oferece aos utilizadores do primeiro sítio um acesso directo às referidas obras"; e que b) "para que haja acto de comunicação, basta que seja posta à disposição do público obra a que as pessoas que compõem esse público possam ter acesso"; ora, "fornecer hiperligações é acto de comunicação (colocação à disposição do público) do administrador do sítio".

Em segundo lugar, é também necessário - determina o Tribunal - que tal comunicação de obra(s) seja dirigida a um "público novo", i.e., "um público que não tenha sido tomado em consideração pelos titulares do direito de autor, quando autorizaram a comunicação pública inicial (Acórdão SGAE C-136/09)". Ora, estabelece o Tribunal, "os utilizadores do sítio Internet gerido pelo titular do sítio a que se acede pelo link (hiperligação) são destinatários potenciais da comunicação inicial e, por isso, fazem parte do público tido em conta pelos 
titulares do direito de autor, quando autorizaram a comunicação inicial". No caso das hiperligações - estabelece o TJUE - há "comunicação ao público", mas não há "público novo". ${ }^{17}$

Deve, pois, concluir-se que, nos termos destes arestos, se os autores não impedem o acesso a obras disponíveis num sítio da Internet, perdem o direito de impedir outros de as comunicarem ao público via hiperligações que dirigem a essa obra livremente acessível no sítio originário. ${ }^{18} / 19$

Contra estes entendimentos, manifestou-se já, nomeadamente, o Tribunal Distrital de Amesterdão, a propósito da hiperconexão que permitia o acesso a fotografias disponíveis on-line: "A hiperligação não autorizada de fotografias disponíveis on-line sem autorização do titular é um acto ilícito de comunicação ao público". ${ }^{20}$ Também várias decisões de tribunais do Reino Unido sustentam a conclusão que o acesso a uma obra, que foi disponibilizada em certo sítio da web sem autorização do titular, constitui um acto ilícito de comunicação ao público e, assim, uma violação do copyright.

Já a ALAI (Association Littéraire et Artistique International) considera que o art. 8 do Tratado sobre Direito de Autor (WCT, da OMPI/WIPO) regula "qualquer comunicação ao público, sem distinguir transmissões primárias e secundárias, [...] o conceito de «novo público» do TJUE muda o conceito de público". ${ }^{21}$

II - Consideramos também relevante o caso TvCatchup, decidido pelo TJUE. Neste, a ITV reclama que a TvCatchup "infringiu o direito de autor, comunicando a obra a um público diferente através de um processo de transmissão electrónica" (a retransmissão electrónica/ streaming): o "novo público"/usuários (Netfix, Spotify) eram autorizados a visionar apenas as transmissões televisivas "streamed" com base numa licença válida apenas para um país (Reino Unido); as receitas da TvCatchup provinham de publicidade exibida antes de o usuá-

17 Assim, também, Ac. TJUE, de 21-10-2014, Best Water International GmbH vs. Michael Mebes et alia: "a(s) obra(s) está(ão) livremente disponível(is) para o conjunto dos internautas num outro sítio da Internet com autorização dos titulares do direito de autor".

18 Assim MELCHIOR WATHELET, Procurador-Geral do Reino Unido: “A colocação/disponibilização de links é necessária à arquitectura da Internet; as obras [assim disponibilizadas] estão acessíveis a todos os utilizadores da Internet".

19 A Dir.Merc.Un.Dig.", na versão proposta pela Comissão Europeia e depois alterada pelo Parlamento Europeu (PE), consagrava expressamente, no seu Considerando 33, que as "hiperligações não constituem acto de comunicação". Esta redacção foi alterada pelo $\mathrm{PE}$, mas o referido Considerando continua a consagrar que "a protecção concedida às publicações de imprensa [relativamente às quais fixa um exclusivo de colocação à disposição do público que atribui aos editores] não abrange as hiperligações".

20 Decisão de 2012 (Sanona Media Netherlands BV et alia us. GS Media BV, 507119 - HAZA 11-2896, NL:RBAMS:2002:BX7043).

21 ALAI - "Opinion proposed to the executive Committee and adopted at its meeting, 17-9-2014, on the criterion "New Public", developed by the Court of Justice of the European Union (CJUE), put in the context of making available and communication to the public", acedida em www.alai.org/.../170327-ALAI-Provisional-opinion_Filmspeler_... . 
rio poder ver os programas "streamed". O TJUE asseverou: "a disponibilização de obras, através da retransmissão de uma transmissão por uma televisão terrestre pela Internet, deve ser considerada uma «comunicação» (no sentido do art. 3/1 Directiva 2001/29), já que significa meios técnicos diferentes dos da comunicação inicial" (Acórdão de 7-3-2013, ITV Broadcasting Ltd, Channel 4 Television Corporation et alia vs. TVCatchup Ltd C-607/11).

III - É nossa opinião que a decisão, acima citada, no caso Svensson e a jurisprudência Comunitária subsequente no mesmo sentido têm um sentido essencialmente correcto. É decisivo qual o "público" potencial que o autor visa ao autorizar a disponibilização da obra em rede. E consideramos mais: a Internet é uma rede global única; a colocação à disposição do público de uma obra ou outro conteúdo protegido por direito autoral na net deve depender de uma autorização também única e deve merecer uma remuneração global por todas as potenciais utilizações que tal disponibilização comporta. Não faz sentido considerar que cada link a outro site é uma comunicação independente de tais conteúdos, visto que apenas liga sítios, abrindo-os a usuários que são os mesmos potencialmente visados pela autorização inicial.

IV - Pensamos até que este conceito ("público/novo público") deveria aplicar-se também à recepção em lugar público de programas radiodifundidos. Desta, que consideramos dever ser livre $^{22}$, se tem dito que o facto de se verificar em "lugar público" é decisivo para determinar o dever de uma remuneração autónoma ao autor: o autor, ao autorizar a radiodifusão, apenas visaria a recepção em privado das emissões radiodifundidas.

Ora, que diferença faz ao autor que a(s) sua(s) obra(s) seja(m) recebida(s) por 5000 pessoas, cada uma no seu lar ou pelas mesmas 5000 pessoas concentradas num estádio? Não é o público potencial da sua obra aquele que determina a autorização do autor e a sua remuneração? Nem se diga que a concentração do público, normalmente num recinto com entradas pagas, proporciona um mais do que provável benefício material ao titular desse recinto, não esperado pelo autor que autoriza e é remunerado pela radiodifusão: é que o facto de o acesso ao lugar público ser ou não remunerado é irrelevante para a nossa lei na definição de "lugar público" (cfr. art. 149. \%/3 CDA: "[lugar] a que seja oferecido o acesso [...] mediante remuneração ou sem ela").

\subsection{O caso Napster e o uso privado}

O programa de computador Napster permitia aos usuários trocar ficheiros de música $\mathrm{MP} 3$, através da Internet, de forma gratuita. Bastava descarregar o programa da Internet e, de 
forma automática, criava-se no disco rígido do computador uma pasta chamada "music"; quando o usuário ligava o computador e abria o programa, podia aceder à música que outros usuários igualmente conectados tinham nessa mesma pasta. Era - cremos que podemos assim chamá-lo - um programa de distribuição digital (partilha / sharing) de ficheiros de música e audiovisuais, em oposição o tradicional carregamento de dados (upload).

O chamado "caso Napster", que opôs a Napster, Inc. à A\&M, Records e outras empresas de música, todas filiadas na Recording Industry Association of America - RAA (No. C 99-5183 MHP No. C 00-0074 MHP), United States District Court for the Northern District of California ${ }^{23}$, concluiu com a decisão que o redireccionamento, operado por hiperligações / hiperconexões que dirigiam para ficheiros $\mathrm{MP} 3$ ilicitamente descarregados, constituía um acto de disponibilização ao público dos mesmos, logo dependente de autorização dos titulares dos direitos. Foi considerado "indisputado que proporcionava o uploading de ficheiros com cópias (ilícitas) e que tal tornava esses ficheiros acessíveis ao público". Mais foi considerado não controvertido que "não pode duvidar-se que a simples notícia da existência de um endereço electrónico acessível na net não constitui comunicação ao público da obra, independentemente de conter eventualmente material ilicitamente colocado em rede".

A decisão acabou por ser: "apesar de a Napster não beneficiar directamente financeiramente com os downloads pelos usuários dos ficheiros $\mathrm{MP}_{3}$, a reiterada cópia de obras protegidas, ainda que as cópias não sejam oferecidas para venda, pode ser considerada uso comercial"; "[...] a Napster tinha conhecimento do uso ilícito pelos usuários"; "[...] a Napster, com este conhecimento, deveria ter bloqueado o acesso aos ficheiros ilícitos e removido estes da sua oferta; a realização de «amostras» (sampling) das obras, que permite aceder-lhes antes da compra para exame/apreciação não constitui uso privado ("fair use"24), já que as «amostras» são, na verdade, cópias integrais e permanentes”; “[...] o facto de a Napster não beneficiar directamente com os downloads pelos usuários não é relevante, [...] a cópia reiterada de obras protegidas pode ser considerada um uso comercial, ainda que as cópias

23 Acedido em: http://bulk.resource.org/courts.gov/c/F3/239/239.F3d.1004.00-16403.00-16401.html.

24 A expressão fair use, a que recorrem os ordenamentos jurídicos anglo-saxónicos, tem significado não exactamente coincidente com o nosso uso privado.

O uso privado é uma utilização não-patrimonial que o usuário faz, em privado, da obra - o uso privado é livre (cfr. art. 81. ${ }^{\circ}$-b) CDA).

O fair use é uma "utilização razoável" de uma obra, incluindo a sua reprodução em cópias ou registos sonoros ou por qualquer outra forma, para fins de crítica, comentário, reportagem de notícias, ensino (incluindo múltiplas cópias para uso em sala de aula), ou investigação - não constitui uma infracção ao direito de autor. Para determinar se a utilização feita de um trabalho para um caso particular é "fair use" os factores a serem considerados são os seguintes: a) o propósito e tipo de utilização, incluindo se o mesmo é de natureza comercial ou educacional sem fins lucrativos; b) a natureza do trabalho copiado; c) a quantidade e proporcionalidade do copiado em relação ao todo; e d) o efeito do uso relativamente ao mercado potencial ou valor do trabalho sob direito de autor (cfr. § 107 USCopyright Law - lei de autor dos Estados Unidos da América ("United States Code, Title 17 - Copyrights", aprovado pelo Act 2010, Pub.L. N. ${ }^{\circ} 111-295,124$ Stat. 3180). 
não sejam oferecidas para venda"; "[...] a larga distribuição dos ficheiros afecta negativamente o mercado de $\mathrm{CD}$, prejudicando a indústria musical".

OLIVEIRA ASCENSÃO ${ }^{25}$ considera que esta decisão põe em causa a liberdade do uso privado, já que "a Napster não procedia ela própria à reprodução. Utilizava programas que lhe permitiam detectar onde se encontrava em rede, disponível para reprodução, a peça que se desejava. Tendo-a apontado ao interessado, era este quem realizava depois a descarga desse ficheiro". E depois, referindo-se à descarga de obras audiovisuais: "[...] Eram, pois, os utentes quem procedia, quer à localização, quer à descarga". Não pensamos assim.

O uso privado - livre -, para que seja lícito, pressupõe que a obra tenha sido licitamente trazida ao "uso" do usuário. Se o usuário não tiver título legítimo de acesso (por exemplo, a compra do livro que lê ou do bilhete de ingresso no concerto ou no cinema a que acede como espectador), o uso é ilícito. Se a obra tiver sido ilicitamente trazida ao seu acesso (cópia ilegal, comunicação pública não autorizada), o uso é ilícito. Ora, o que está em causa no caso da Napster é o uso, ainda que privado (embora multiplicado por milhões de usuários), de obras para as quais o usuário não tinha título legítimo de uso: o que furta um livro não tem direito a lê-lo, o que ingressa sem bilhete num concerto ou num cinema não tem direito a assistir ao espectáculo exibido, o que acede - ainda que a título privado - a uma obra ilicitamente disponibilizada na net viola o direito exclusivo do seu autor.

\subsection{As medidas tecnológicas de protecção}

I - O art. 6/3 da Directiva 2001/29 refere a sistemas técnicos de identificação e protecção de obras intelectuais - as chamadas medidas tecnológicas: "quaisquer tecnologias, dispositivos ou componentes que [...] se destinem a impedir ou restringir actos [...] que não sejam autorizados pelo titular do direito de autor ou direitos conexos ou do direito sui generis".

Estas designadas "medidas tecnológicas" compreendem ${ }^{26}$ :

a) medidas que controlam o acesso aos conteúdos designados protegidos;

b) medidas que controlam apenas algumas utilizações desses conteúdos (reprodução, distribuição, comunicação ao público, incluindo a colocação à disposição do público);

c) tecnologias que protegem a integridade das obras (por ex.: PDF);

d) medidas que possibilitam a eficaz gestão dos direitos na rede, através de mecanismos de medição do acesso ou da utilização das obras e prestações (por ex.: os Electronic Copyright Management Systems ou Digital Rights Management).

25 JOSÉ DE OLIVEIRA ASCENSÃO, Propriedade Intelectual e Internet, $n .^{\circ} 11$, acedido em www.fd.ulisboa.pt.

26 Segundo a classificação de KOELMAN, Kamiel e HELBERGER, Natali, apud CLÁUDIA TRABUCO, Direito de autor, intimidade privada e ambiente digital: reflexões sobre a cópia privada de obras intelectuais, in Revista Iberoamericana de Filosofia, Política y Humanidades, Año 9, n. ${ }^{\circ}$ 18, 2007, VI. 
A estas, devem juntar-se medidas tecnológicas de identificação e de seguimento do percurso das obras e prestações (art. 217.\%/2 CDA), que facilitam a exploração económica das obras, possibilitando ${ }^{27}$ :

a) a contratação em linha, facilitando a identificação das obras e sua autenticação, mediante sistemas de identificação de objectos digitais;

b) a garantia da integridade das obras e a sua autenticação, através de assinaturas digitais;

c) o controlo de acesso, mediante a utilização de palavras-chave;

d) o rastreio das utilizações das obras e prestações nas redes digitais;

e) o registo e cobrança de compensações pelas utilizações, através de sistemas de processamento de pagamentos electrónicos.

II - A aplicação destas medidas suscita, contudo, vários problemas, sobretudo ligados à relação entre a protecção conferida e o respeito pelos limites que a própria lei e Directivas impõem aos direitos exclusivos dos titulares pela consagração de utilizações livres das obras e outros conteúdos protegidos - o art. 6.\%/4 da Directiva 2001/29 e o art. 221.\%/1 CDA prevêem-no. Se a utilização de uma obra é livre, i.e., não depende de autorização do titular do direito de autor, não faz sentido restringir o acesso à mesma por via das ditas medidas tecnológicas.

O principal problema que a aplicação destas medidas tecnológicas suscita é que as mesmas são cegas: limitam tanto, legitimamente, o acesso a conteúdos protegidos como aos que o não são (como certos conteúdos meramente noticiosos), ou que, sendo protegidos, são livremente utilizáveis para certos fins e sob determinadas condições nos termos da lei ou de contrato.

Devem, assim, respeitar-se utilizações livres consentidas na lei de autor (consagradas principalmente no art. $75 .^{\circ} \mathrm{CDA}$ ) e o uso privado (art. 81..$^{\circ}$-b) CDA). Por outro lado, estas medidas não se aplicam a obras que tenham sido disponibilizadas em rede em cumprimento de acordos entre os titulares e os utilizadores (art. 222. ${ }^{\circ} \mathrm{CDA}$ ).

Em reacção a comportamentos que desvirtuem estas medidas tecnológicas, a lei assegura: a) tutela penal; b) a apreensão de equipamentos e dispositivos que anulem as medidas de protecção; c) a responsabilidade civil. 


\section{Perspectivas. A proposta de Directiva relativa aos direitos de autor no mercado único digital (a utilização digital de conteúdos protegidos)}

A Dir.Merc.Un.Dig.* não refere unicamente, como se depreende do seu título, tão-só à utilização e uso de conteúdos protegidos na net, mas também a diversos outros tipos de exploração económica e uso de obras digitalizadas. Salientemo-los.

\subsection{Excepções e limitações aos direitos exclusivos para efeitos de investigação científica}

A Directiva em questão (art. $2 .^{\circ} / 1$ ) define "organismo de investigação" como aquele cujo principal objectivo seja a realização de investigação sem fins lucrativos com missão de interesse público e cujos resultados não sejam apreciáveis por uma empresa. Trata depois de enunciar uma série de condições e requisitos cumulativos que delimitam o exclusivo, consagrando a liberdade de utilização das obras e outros conteúdos protegidos nos seus limites.

Em primeiro lugar (art. 3..$^{\circ}$ e Considerandos 10 a 13 da Dir.Merc.Un.Dig.*), especifica que apenas os direitos de reprodução de obras e de prestações e o direito de extracção do conteúdo de bases de dados sofrem limitação, acrescentando - o que é relevante quando pensamos na disponibilização em rede desses conteúdos - que não ficam prejudicadas as reproduções meramente técnicas transitórias.

Em segundo lugar, a Dir.Merc.Un.Dig.* estabelece que estas limitações não admitem convenção em contrário, o que sempre evidencia o suposto interesse público das mesmas.

Em terceiro lugar, especifica que estes limites são consagrados apenas para a realização de prospecção de textos e dados para fins de investigação científica. Em compensação, autoriza os titulares a aplicar medidas para garantir a segurança e a integridade das redes e bases de dados que acolherem as obras e outros conteúdos protegidos.

\subsection{Excepções e limitações aos direitos exclusivos para efeitos de ilustração didáctica}

Os direitos autorais que sofrem limite ou excepção de utilização livre neste âmbito (art. 4. ${ }^{\circ}$ e Considerandos 15 a 17 da Dir.Merc.Un.Dig. ${ }^{*}$ são já, além do direito de reprodução de obras e prestações e de extracção do conteúdo de bases de dados, o direito de comunicação ao público, incluindo o direito de colocação à disposição do público, bem como o direito de autor e o direito sui generis relativos às bases de dados e o direito de reprodução de programas de computador.

Estas excepções compreendem qualquer utilização digital de obras e outros conteúdos protegidos, logo não apenas a sua utilização em rede (www). Estas utilizações estão limita- 
das estritamente pelo seu fim, que deve circunscrever-se à ilustração didáctica (actividades pedagógicas e de aprendizagem) e na medida justificada por objectivos não comerciais.

As utilizações livres consentidas devem realizar-se em estabelecimentos de ensino primário, secundário, superior ou profissional, presencialmente ou através de rede electrónica apenas acessível a estudantes e pessoal docente, e ser acompanhadas de indicação da fonte e, se possível, do nome do autor. Deve contemplar-se as necessidades específicas dos deficientes, o que consta já, em parte, do art. $75{ }^{\circ} / 2-i$ ) CDA.

$\mathrm{O}$ acesso aos conteúdos pode ser protegido por mecanismos de autenticação.

A existência de "licenças adequadas" que autorizem já os actos descritos faz não aplicáveis estas excepções.

\subsection{Excepções e limites para efeitos de conservação de obras}

As excepções consagradas nesta sede (art. 5. ${ }^{\circ}$ e Considerandos 18 a 22 da Dir.Merc.Un.Dig.*) respeitam ao direito de reprodução, incluindo a reprodução digital, de obras, os direitos de reprodução e de extracção de bases de dados e o direito de reprodução de programas de computador. Não cabe, pois, aqui, a colocação à disposição do público na Internet destes conteúdos.

Estão abrangidas as obras e outros conteúdos protegidos que façam parte da colecção de bibliotecas ou museus acessíveis ao público, arquivos ou instituições responsáveis pelo património cinematográfico ou sonoro.

As excepções consagradas neste âmbito têm por objectivo exclusivo, que deve naturalmente limitar as utilizações consentidas, a conservação das obras em questão, na medida estritamente necessária a esta. Não estão, pois, autorizadas neste âmbito as utilizações que impliquem a reprodução por entidades estranhas aos estabelecimentos indicados, por exemplo a cópia digital para fins estranhos às instituições em causa.

Sobre este ponto, deve, contudo, ter-se presente o disposto no art. $75 . \% / 2$-e) CDA: «2 - São licitas, sem o consentimento do autor, as seguintes utilizações da obra: [...] e) A reprodução, no todo ou em parte, de uma obra que tenha sido previamente tornada acessivel ao público, desde que tal reprodução seja realizada por uma biblioteca pública, um arquivo público, um museu público, um centro de documentação não comercial ou uma instituição científica ou de ensino, e que essa reprodução e o respectivo número de exemplares se não destinem ao público, se limitem às necessidades das actividades próprias dessas instituições e não tenham por objectivo a obtenção de uma vantagem económica ou comercial, directa ou indirecta, incluindo os actos de reprodução necessários à preservação e arquivo de quaisquer obras». Verifica-se, pois, que, com excepção da previsão Comunitária que inclui entre as utilizações livres para estes fins as realizadas por "instituições responsáveis pelo 
património cinematográfico [como a Cinemateca Portuguesa] ou sonoro", tudo o mais que a Dir.Merc.Un.Dig. * consagra neste âmbito está já vertido na lei portuguesa.

\subsubsection{Licenças não exclusivas para fins não comerciais de obras e outros conteúdos que deixaram de ser comercializados}

I - A Dir.Merc.Un.Dig. * consagra (art. 7. $^{\circ}$ ) uma importante inovação no domínio das utilizações livres de obras: «Os Estados-Membros devem prever que, sempre que uma entidade de gestão coletiva [egc], em nome dos seus sócios, conceder uma licença não exclusiva para fins não comerciais a uma instituição responsável pelo património cultural para a digitalização, distribuição, comunicação ao público ou colocação à disposição do público de obras que deixaram de ser comercializadas ou outro material protegido que fazem permanentemente parte da coleção da instituição, essa licença não exclusiva pode ser alargada ou considerada aplicável aos titulares de direitos da mesma categoria dos que são abrangidos pela licença e não são representados pela entidade de gestão coletiva». Consideramos que as normas que resultem da transposição, sem mais, deste preceito serão muito limitadoras dos direitos dos autores e demais titulares de direitos autorais.

Na verdade, impor a extensão da aplicação de uma licença concreta, normalmente eficaz apenas inter partes e remunerada como tal, a não representados (e não remunerados) pela egc em causa ${ }^{28}$ é óbvia e injustificadamente lesivo da posição destes. Não vemos que a hipotética salvaguarda do que provavelmente se apelidará "interesse público" na conservação das obras justifique esta grave limitação aos direitos autorais. É certo que, por outro lado, "todos os titulares de direitos devem poder, em qualquer momento, opor-se a que as suas obras ou outro material protegido sejam considerados como tendo deixado de ser comercializados, bem como excluir a aplicação da licença às suas obras ou outro material protegido" (alínea c)). Todavia, não deveria exigir-se que a não aplicação de uma mera licença - que tem efeitos limitadores de direitos autorais (absolutos) de quem a não outorga - devesse depender de manifestação de vontade dos titulares desses direitos.

II - A aplicação deste preceito depende ainda da verificação de condições cumulativas.

Em primeiro lugar, é condição que "a entidade de gestão coletiva seja, com base em mandatos de titulares de direitos, amplamente representativa dos titulares de direitos na categoria de obras ou outro material protegido e dos direitos que são objeto da licença" (alínea a)). Significa isto que só entidades de gestão colectiva amplamente representativas

28 Nos termos da lei (art. 73. $\% 1 \mathrm{CDA}$ ), as egc representam os titulares dos direitos de autor e direitos conexos, resultando essa representação da simples qualidade de sócio ou aderente. 
poderão aspirar a celebrar licenças com a eficácia acima descrita, ou seja, licenças cujos efeitos atinjam igualmente titulares de direitos não representados.

É também condição de aplicação da regra acima enunciada que "seja garantida a igualdade de tratamento de todos os titulares de direitos em relação às condições da licença" (alínea b)), o que parece natural.

\subsection{Novos direitos dos editores de publicações de imprensa}

O art. $11 .^{\circ}$ e os Considerandos 31 a 36 da Dir.Merc.Un.Dig. . consagram um direito conexo dos editores de publicações de imprensa (jornais, revistas, sítios de notícias na web ${ }^{29}$ ).

Este direito conexo dos editores diz respeito às utilizações digitais das obras em questão e compreende as faculdades de reprodução e de colocação à disposição do público de obras na net. A sua consagração não prejudica, porém, a subsistência dos direitos de autor sobre os contributos criativos (artigos, imagens, objectos audiovisuais) integrados nas referidas publicações e sítios na net. Tal salvaguarda a celebração de acordos contratuais individuais para a exploração económica em separado desses contributos criativos pelos respectivos autores, nomeadamente com editores dessas peças criativas; isto, é bom de ver, sem prejuízo da exploração da obra colectiva (jornal, revista, etc.) no seu todo.

O direito conexo do editor, aqui, assim, previsto, caduca vinte anos após a publicação do jornal ou do sítio na web.

Em matéria contratual, assinala-se que a Dir.Merc.Un.Dig.* prevê que, caso o autor da obra colectiva ou dos contributos criativos individuais nesta integrados tenha concedido licença para exploração destes, tem o editor o direito de reclamar parte da compensação por aquele recebida pela utilização da obra. Consideramos, a este propósito, que a consagração deste direito conexo, que não é mais do que um direito empresarial que visa complementar o retorno do investimento na edição, coloca sérias dúvidas sobre a bondade de, a reboque dos direitos dos autores pelas obras que criam, se retirar mais uma fatia dos proventos que normalmente lhes caberiam e que assim passa a reverter para os editores.

Merece também realce a inovadora previsão Comunitária, nesta sede, da obrigatoriedade, imposta aos prestadores de serviços em linha / em rede, da celebração de acordos de licenciamento com os titulares dos direitos autorais. Tal significa que também aqueles se deverão submeter ao respeito e remuneração dos exclusivos jusautorais relativos às obras que disponibilizem em rede, devendo licenciar expressamente tal disponibilização junto dos titulares dos direitos.

29 Definidos no art. 2. $\% 4$ da Dir.Merc.Un.Dig.* 


\subsection{O uso de tecnologias de reconhecimento de conteúdos como instrumento da} efectivação de acordos entre prestadores de serviços em linha e titulares de direitos Conforme consagrado no art. $13 .^{\circ}$ e nos Considerandos 38 e 39 da Dir.Merc.Un.Dig., no pressuposto de que os prestadores de serviços da sociedade da informação armazenam e facultam o acesso público a grandes quantidades de obras e outros conteúdos protegidos carregados por clientes, fica prevista a adopção de medidas que assegurem o funcionamento de acordos com titulares de direitos relativos à utilização de obras ou que impeçam a colocação à disposição (ilícita), pelos seus serviços, de obras ou outro material protegido, que sejam identificados pelos titulares de direitos através da cooperação destes com os prestadores de serviços. Estas "medidas" podem consistir em tecnologias de reconhecimento de conteúdos.

Os prestadores de serviços devem facultar aos titulares de direitos informações adequadas sobre o funcionamento e a implantação das medidas, bem como sobre o reconhecimento e a utilização das obras.

\subsection{Obrigação de transparência para efectivação da remuneração aos titulares de direitos}

Uma das dificuldades mais sentidas pelos titulares de direitos autorais (autores, artistas, produtores de fono/videogramas, organismos de radiodifusão, empresários de espectáculos, produtores de bases de dados e editores) quanto à efectivação dos seus direitos perante a colocação das suas criações on-line é a de controlar a utilização e uso das mesmas e assegurar uma remuneração adequada por essas utilizações e usos.

A Dir.Merc.Un.Dig.* (art. 14. ${ }^{\circ}$ e Considerandos 40 a 43) estabelece a necessidade de se consagrar a obrigação daqueles a quem foram concedidas licenças de utilização ou transferidos direitos autorais de prestar informações sobre a exploração de obras e prestações artísticas verificada (on e off-line) que permita avaliar continuadamente o valor dos direitos concedidos.

Face à constante dificuldade de renegociação de montantes a pagar aos titulares de direitos, devido ao fraco poder negocial destes uma vez "lançadas" as suas criações em rede, a Dir.Merc.Un.Dig.* estabelece que, nos acordos que aqueles licenciados e titulares derivados de direitos negoceiem, devem ficar previstos mecanismos de ajustamento das remunerações aos titulares originários, bem com ser previstos mecanismos de resolução alternativa de litígios neste âmbito. 


\section{Licenças multiterritoriais de utilização em rede de obras musicais}

A Directiva 2014/26/UE ${ }^{* 30}$, respeita, entre outras matérias, às licenças multiterritoriais de exploração em linha/em rede de obras musicais. São "licenças multiterritoriais relativas a obras musicais" as que autorizam a utilização de obras e prestações artísticas musicais em rede e abrangem mais do que um Estado-membro da UE.

As entidades de gestão colectiva (egc) devem ter capacidade para tratar electronicamente, de modo eficiente e transparente, os dados necessários à administração das licenças multiterritoriais que concedem (art. 24. ${ }^{\circ}$ da Directiva 2014/26).

Este tratamento deve compreender: a) a identificação do repertório; b) o acompanhamento da utilização; c) a facturação aos utilizadores; d) a cobrança de receitas; e) a distribuição de receitas aos titulares.

As egc que concedam licenças por meios electrónicos devem comunicar aos prestadores dos serviços em linha, aos titulares de direitos representados e às demais egc informações actualizadas que permitam identificar o repertório de música representado, bem como acompanhar a utilização de direitos pelos prestadores de serviços em linha/em rede que sejam titulares de licenças multiterritoriais.

Nos termos desta Directiva, cabe também às egc distribuir os montantes cobrados devidos aos titulares de direitos.

\section{BIBLIOGRAFIA}

ALAI - "Opinion proposed to the executive Committee and adopted at its meeting, 17-9-2014, on the criterion "New Public", developed by the Court of Justice of the European Union (CJUE), put in the context of making available and communication to the public", acedida em www.alai.org/.../170327-ALAI-Provisional-opinion_Filmspeler_... ASCENSÃO, José de Oliveira

_ Propriedade Intelectual e Internet, acedido em www.fd.ulisboa.pt

MELLO, Alberto de Sá e

— O direito pessoal de autor no ordenamento jurídico português, Lisboa, 1989

— Tutela jurídica das bases de dados (a transposição da directriz 96/9/CE), in "Direito da Sociedade da Informação" (coligação de obras coordenada pelo Professor Doutor José de Oliveira Ascensão) - Vol. I, Coimbra, 1999

— Os multimedia - regime jurídico", in "Direito da Sociedade da Informação" (coligação de obras coordenada pelo Professor Doutor José de Oliveira Ascensão) - Vol. II, Coimbra, 2001

— Filmagem de espectáculos desportivos e «direito de arena», in "Creaciones Audiovisuales y Propiedad Intelectual" (coligação de obras coordenada pelo Professor Doutor Carlos Rogel Vide, Catedrático da Universidad Complutense de Madrid), Madrid, 2001

$30 \mathrm{Cfr}$. o nosso Principais aspectos e alguns problemas da gestão colectiva de direitos de autor e direitos conexos no ambiente digital - o regime em Portugal, em Espanha e no direito comunitário, in Revista da Ordem dos Advogados, Ano 76, Lisboa, Jan. / Dez. 2016. 
- A telecomunicação electrónica em rede de obras intelectuais na "sociedade da informação" - a Directriz 2001/29/CE e a sua transposição em Portugal pela Lei n..$^{\circ}$ 50/2204, in "Direito da Sociedade da Informação" (coligação de obras coordenada pelo Professor Doutor José de Oliveira Ascensão) - Vol. VII, Coimbra, 2008

- Manual de Direito de Autor e Direitos Conexos, 2. ${ }^{\text {a }}$ ed., Coimbra, 2016

- Principais aspectos e alguns problemas da gestão colectiva de direitos de autor e direitos conexos no ambiente digital - o regime em Portugal, em Espanha e no direito comunitário, in Revista da Ordem dos Advogados, Ano 76, Lisboa, Jan. / Dez. 2016

— Direito exclusivo do autor e excepções a favor de bibliotecas, museus e arquivos - nos direitos português, brasileiro e espanhol, in Revista Fórum de Direito Civil, ano 6 - n. ${ }^{0}$ 14, Belo Horizonte, Brasil, 2017

- O direito pessoal (dito «moral») de autor - nos ordenamentos jurídicos português eespanhol, in Revista de Direito Intelectual, Lisboa, n. ${ }^{\circ} 1-2017$

TRABUCO, Cláudia - Direito de autor, intimidade privada e ambiente digital: reflexões sobre a cópia privada de obras intelectuais, in Revista Iberoamericana de Filosofia, Política y Humanidades, Año 9, n. ${ }^{\circ}$ 18, 2007, VI

\section{Referências jurisprudenciais}

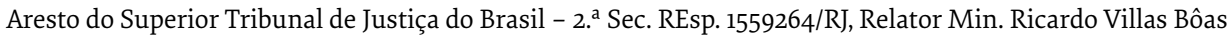
Cuevo, julgado em 8/2/2017

Ac. TJUE, de 21-10-2014, Best Water International GmbH vs. Michael Mebes et alia

Acórdão TJUE, de 4-10-2011, Football Association Premier League C-403/08 e C-429/08

Acórdão, de 2012, Sanona Media Netherlands BV et alia vs. GS Media BV, 507119 - HAZA 11-2896, NL:RBAMS:2002:BX7043

Acórdão Napster, Inc. à A\&M, et alia, No. C 99-5183 MHP No. C 00-0074 MHP, United States District Court for the Northern District of California, acedido em: http://bulk.resource.org/courts.gov/c/F3/239/239. F3d.1004.00-16403.00-16401.h 


\title{
Justiça \& Cidadania: Aportações de Direito \& Arte
}

\author{
Justice \& Citizenship: Contributions from Law \& the Arts
}

PAULO FERREIRA DA CUNHA ${ }^{1}$

GALILEU - REVISTA DE DIREITO E ECONOMIA - e-ISSN 2184-1845

Volume XIX - $1^{\text {st }}$ July Julho $-31^{\text {TH }}$ December Dezembro $2018 \cdot p p .28-48$

DOI: https://doi.org/10.26619/2184-1845.XIX.2.1

Submitted on October $25^{\text {th }}, 2018$. Accepted on November $11^{\text {th }}, 2018$

Submetido em 25 de Outubro, 2018 . Aceite a 11 de Novembro, 2018

RESUMO O presente artigo visa uma perspetiva epistemo-metodológica pós-disciplinar, na senda dos estudos da macrofilosofia de Gonçal Mayos, procurando colocar em diálogo Direito e Pintura.

O seu objeto é captar por diversos ângulos aspetos salientes do diálogo entre Justiça (e Direito) e cidadania, num tempo de crise para ambos. Recua às questões da ordem social natural ou construída para desaguar nas grandes interrogações políticas da contemporaneidade.

Palavras-chave Justiça, Cidadania, Arte e Direito, Arte.

ABSTRACT The present article aims at a post-disciplinary epistemological-methodological perspective, in the path of studies of the macrophilosophy of Gonçal Mayos, seeking to put into dialogue Law and painting.

Its purpose is to capture from various angles aspects of the dialogue between Justice (and Law) and citizenship, in a time of crisis for both. It goes back to the questions of the natural or constructed social order to pour into the great political questions of contemporary times. KEYworDs Justice, Citizenship, Art and Law, Art.

1 Catedrático e Diretor do Instituto Jurídico Interdisciplinar da Faculdade de Direito da Universidade do Porto. 


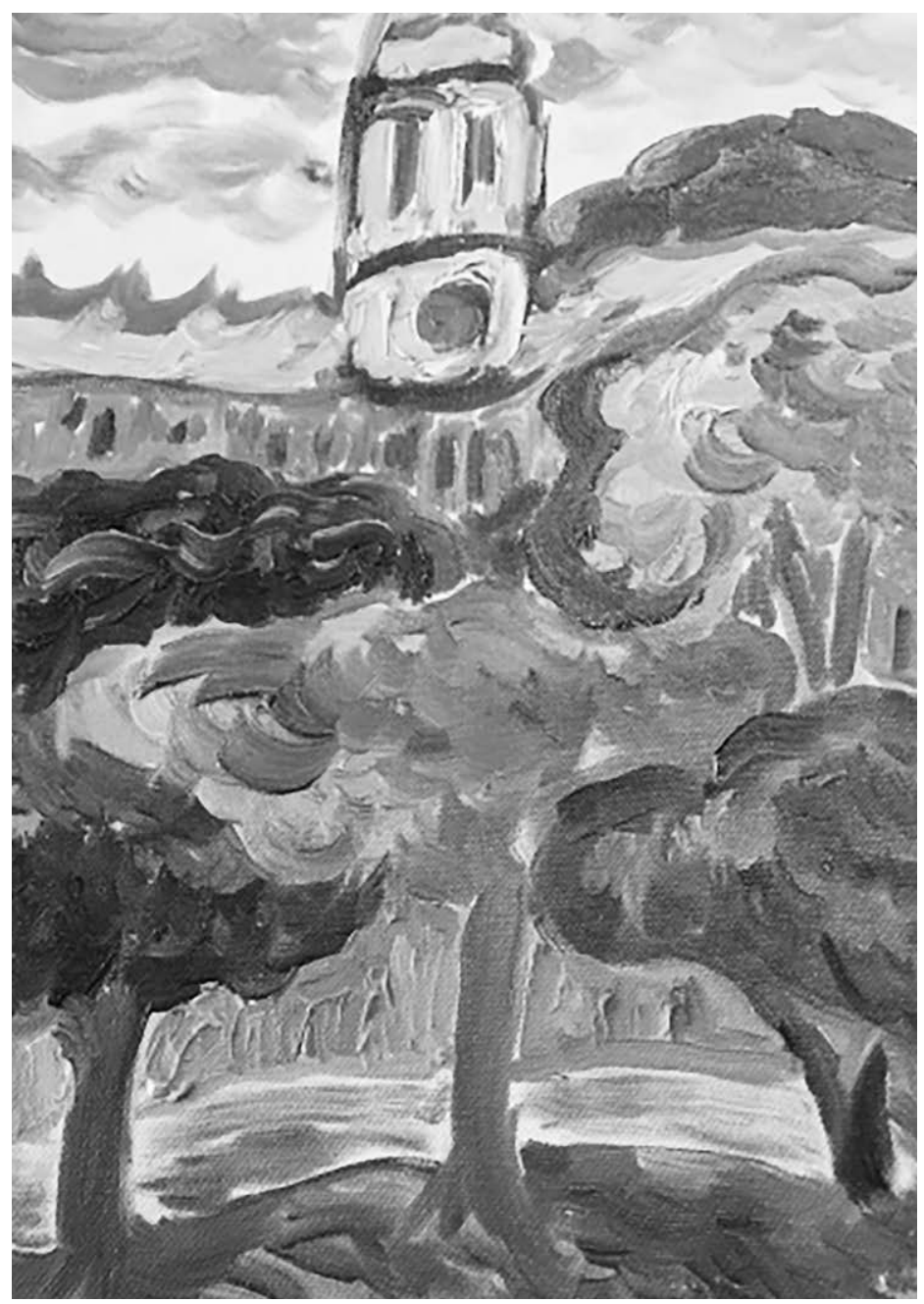

(“A Torre e o Rio" - óleo sobre tela, Porto, abril de 2018).

\section{Nomos / Taxis. Ordem Natural e Ordem Artificial}

Antes de se falar do Direito, e muito antes de se falar da Cidadania, tem de se procurar entender o que é (o que será ou possa ser: porque nestas matérias há muito de insondável) a (ou uma eventual) ordem das coisas, seja ela natural ou social. O Direito e a Cidadania desenham-se sobre uma tela de ordem, ou de desordem? Deveria ser sempre de ordem, evidentemente. E essa ordem implica ainda a dimensão humana da mesma: a questão da 
natureza ou condição humana ${ }^{2}$. Ordem de coisas, ordem de pessoas - natureza das coisas, natureza humana...

Os antigos burgos, medievais ou anteriores, como a cidade do Porto, em que nasci (e que a imagem vagamente lembra, em composição livre) eram entidades naturais, que cresciam como a vegetação, com uma dinâmica orgânica. E daí a tortuosidade das suas vias, ao contrário do traçado racional de cidades mais tardias, movidas pelo utopismo planificador: que também tem a sua sedução, mas é algo de bem diverso. Mas a Cidade (as cidades em geral) é hoje, com as organizações urbanísticas, um exemplo de táxis, não de nomos.

Esta dicotomia essencial e paradigmaticamente útil foi recordada nomeadamente em Direito, Legislação e Liberdade, por Hayek ${ }^{3}$. Mas não cremos que tenha um cunho ideológico muito significativo.

Cremos assim que a distinção nomos / táxis é perfeitamente assimilável por qualquer tipo de pensamento (nele integrável), pelo menos se não for excessivamente englobador, unicitário, totalitário. Não é que ela prove que o natural é o capitalismo anárquico e o artificial o que o não seja (mesmo um discreto e capitalismo regulado de economia social de mercado num Estado suavemente, timidamente, social). Uma coisa são normas naturais. No limite, as agraphoi nomoi ${ }^{4}$ invocadas por Antígona contra Creonte no conhecido mito de Édipo, admiravelmente posto em cena na peça Oidipus Tyranos, ou Oedipus rex, na sua versão latinizada, por Sófocles (que desenvolve o tema, nos seus vários aspetos, antecedentes e desenvolvimentos, nas diferentes peças do Ciclo Tebano5).

Trata-se nesse caso de leis não escritas, superiores às escritas, às postas voluntariamente pelas sociedades ou pelos seus governantes (como era o caso de um decreto de Creonte punindo um morto com o não sepultamento: embora a questão seja mais complicada, como explicou um Stamatios Tzitzis ${ }^{6}$ ). Pode remeter-se, assim, para o Direito Natural ou, pelo menos, para a lei natural. São Tomás de Aquino, numa dificilmente superável classificação da normatividade, na Suma Teológica7 , explica os vários tipos de leis e Direito. Assim, o Direito Natural é Direito, é juridicidade, mas a lei natural é aquela que está inscrita no

2 Cf. o nosso livro O Ponto de Arquimedes. Natureza Humana, Direito Natural, Direitos Humanos, Coimbra, Almedina, 2001.

3 HAYEK, F. A. - Droit, législation et liberté. I - Règles et ordre, trad. fr.. Paris : PUF, 1973.

4 BARROS, Gilda Naécia Maciel de - Agraphoi Nomoi. São Paulo: "Notandum”, vol. 3, ed. online: http://www.hottopos. com/notand3/agrafoi.htm. Ultimamente consultado em 29 de agosto de 2018.

5 Tragiques Grecs. Eschyle / Sophocle. Paris: Gallimard, 1967.

6 TZITZIS, Stamatios - Introduction à la philosophie du droit. Paris: Vuibert, 2011. Idem - La Formation du droit en Grèce, in Instituições de Direito, org. nossa, vol. I, Coimbra : Almedina, 1998, p. 191 ss..; Idem - La Philosophie Pénale. Paris: P.U.F., 1996, trad. port., notas e comentários de Mário Ferreira Monte. Filosofia Penal. Porto: Legis, 1999.

7 Uma edição que usamos normalmente é a Summa Theologiae, trad. fr., Somme Théologique. Paris: Cerf, 1984-86, 4 vols.. Mas há muitas mais... 
coração dos homens, ou seja, é afinal uma forma de consciência moral - isso já o tinha visto São Paulo, e mais tarde será glosado por outros, como o próprio Jean-Jacques Rousseau.

Assim, nomos pode ligar-se aos aspetos naturais da moralidade e da juridicidade (sabe-se que antes do corte epistémico romano, estavam ligadas, aliás, com a política, a religião, etc., no que se convencionou por chamar "primeira" função "política" dos indo-europeus). Nomos não é a cidade: é a vegetação e é o rio. A natureza neste estado é que corresponde à ordem natural. Claro que, como acabamos de ver, também há coisas humanas submetidas ao Nomos. Mas afora alegorias de Antígona e outros heróis da Justiça, são difíceis de representar.

A torre da cidade (e é uma torre civil, não um campanário) é que simboliza a táxis, ordem artificial, voluntária, querida. Não nascem torres nas planuras, não crescem palácios nas florestas. Têm de ser construídos. Assim como as leis humanas, leis positivas, necessitam de legisladores.

A integração harmónica entre natureza e cultura é sempre o grande segredo: da cidade de betão ou de pedra com o que nela há de verde e água e pedra não trabalhada, terra, etc. Assim, do que se trata em Direito é que o Direito da cidade, o correspondente aos palácios e às torres, esteja em harmonia com o Direito Natural. O qual não é direito ambiental ou da natureza física, mas da natureza moral, de que a física pode eventualmente ser uma metáfora. Por vezes, até, uma metáfora ao contrário: Porque o Direito Natural é o contrário de uma natureza desregrada e sem ordem, a chamada "lei da selva".

Mas insistamos na metáfora positiva: rio e vegetação, naturais, enquadram e na verdade até se sobrepõem à torre e ao esboço de palácio. É o natural que deve determinar o positivo. É o Nomos que tem de comandar a táxis. E que o capitalismo é táxis é curioso que foi tese do bom selvagem de Rousseau, e da Origem da Família, da Propriedade e do Estado, de Engels, baseado em Lewis H. Morgan e nas notas à margem que Marx escreveu no seu Ancient Society ${ }^{8}$. Hoje, como aflorámos já, há outros autores em cena, e a polémica continua. Porém note-se: táxis ou nomos, as coisas valem pelo que são. Em princípio, tem-se nomos por bom sistematicamente. Menos a dita "lei da selva". A é evidente que o Direito positivo é uma forma de táxis que deve basear-se no nomos.

8 ROUSSEAU, Jean-Jacques - Oeuvres Complètes. Paris: Seuil, 1971, 3 vols.. Muito especialmente o Contrato Social e o Discurso sobre a origem e os fundamentos da desigualdade entre os homens. trad. port., Porto: Athena, 1964. ENGELS, Friedrich - A Origem da Família, da Propriedade Privada e do Estado. n/ ed. trad. port. de H. Chaves. Lisboa: Presença, s.d.. MORGAN, Lewis H. - Ancient Society, or researches in the lines of Human Progress from Savagery through Barbarism to Civilization. Londres: Mac Millan, 1877. V. ainda, v.g., ALVES, João Lopes - Rousseau, Hegel e Marx. Percursos da Razão Política. Lisboa: Livros Horizonte, 1983. 
Por tudo, é melhor manter a questão do Direito Natural fora da physis física não culturalizada, e colocá-lo ao nível pelo menos de alguma Razão9. Foi o grande projeto iluminista do séc. XVIII, um Direito Natural racional. Mesmo analisando alguns passos de Tomás de Aquino não podemos deixar de entrever nele muito de Razão, de racionalidade...

Não olvidemos também que, acima da torre, estão nuvens. Digamos que, na perspetiva tomista, elas poderiam simbolizar a lei divina. Mas só olha para cima quem quer... Não é necessária essa dimensão para que possa haver ao menos alguma Justiça na terra, como sublinharia, talvez pela primeira vez, Hugo Grotius, um dos fundadores do Direito Internacional Público, como se sabe.

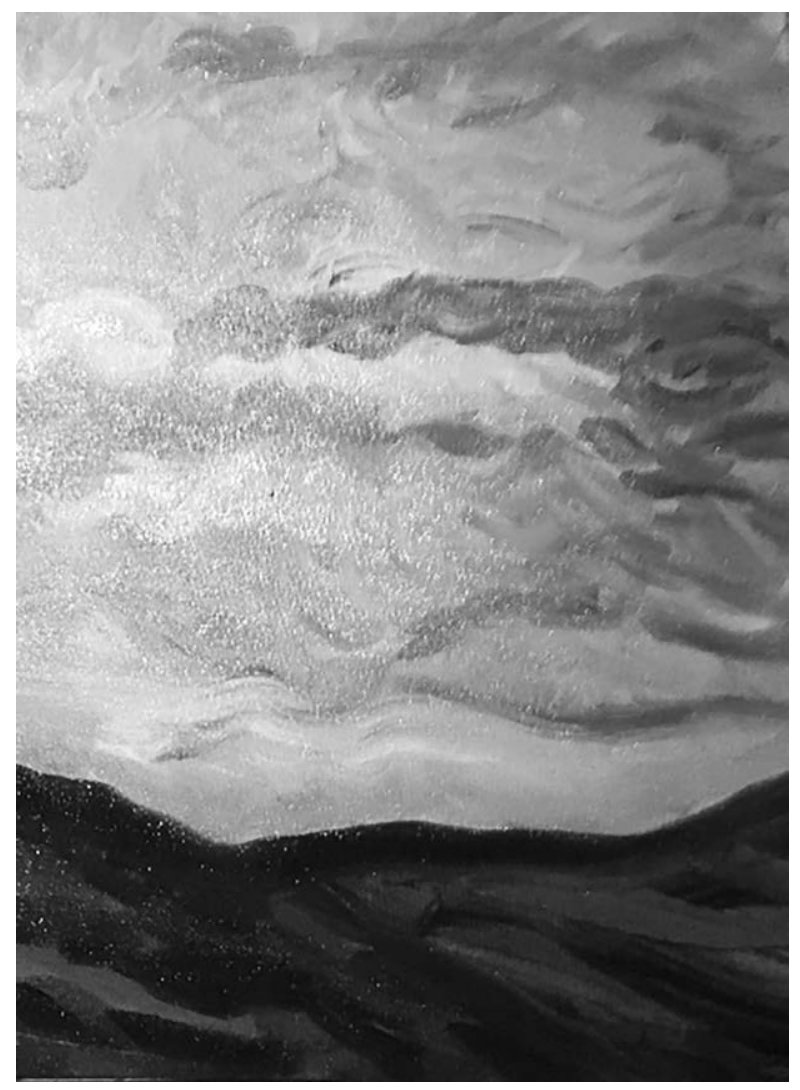

(“Anunciação" - óleo sobre tela, Porto, abril de 2018).

9 Cf. MALTEZ, José Adelino - Voegelin e a Procura do Direito Natural, Prefácio a A Natureza do Direito e outros textos jurídicos, de Eric Voegelin. Lisboa: Vega, 1998. 


\section{Direito, Sentidos, Mentalidades, Ética}

Janelas da Alma são os olhos. Na verdade, são-no todos os sentidos. O Direito tem uma ligação curiosa, interessante, significativa com os sentidos, como desenvolvemos no nosso livro Le Droit et les sens ${ }^{10}$.

Não parece que o Direito, que precisa de ser prudente (veja-se, desde logo, a expressão Juris-prudência, que tanto significa as decisões dos juízes como a totalidade da scientia iuridica), e portanto tem absoluta necessidade de conhecer todos os dados dos problemas que lhe é dado resolver, como "medicina da cultura", "tradutor universal", grande mediador, possa dar-se ao luxo de desprezar nenhuma fonte de conhecimento sensivel. Precisa, evidentemente, de utilizar todos os sentidos. Assim, mesmo o olhar, que já foi considerado fonte de possível queda de favoritismo, mesmo o olhar, insistimos, deve ser utilizado.

Não nos iludamos com o que nos tem sido dito, há uns tantos séculos: Uma Justiça cega não pode julgar bem. Não é eliminando a tentação ou os fatores de risco que se supera o problema. Pelo contrário: o Direito deve bem ver o rico e o pobre, o feio e o bonito, tudo o que seja fator de sedução ou de repulsa, e mesmo assim vendo deve ser imparcial. Porque o problema não está na janela, no olhar, mas na cabeça e no coração do julgador. E o julgador, como o Rei Salomão (que via bem os pleiteadores, e quase o vemos a tocar-lhes), deve ter, antes de mais, "um coração inteligente", que é também conceito retomado por Alain Finkielkraut, no seu livro homónimo"1.

Hoje em dia fala-se muito, como discurso legitimador (entre nós desde João Baptista Machado) ou psitacista, de "janelas de oportunidade" como sinónimo quase de "crise é oportunidade" e outras manifestações da síndrome do limão doce. Evidentemente, estes discursos legitimadores, embalos da consciência crítica, têm sempre algo de verdade - como bem observou o poeta popular António Aleixo: "p'ra mentira ser mentira / e atingir profundidade / tem de trazer à mistura / qualquer coisa de verdade". Mas é dessas janelas que curamos. Também houve janelas de que se lançaram idosos despejados de suas casas durante a crise em Espanha - segundo foi noticiado...

As janelas de que falamos aqui são outras ainda, embora deva ficar o registo de todas. As janelas são as janelas do próprio ser, da própria circunstância (no singular, como em Ortega y Gassett, claro: não com o plural do barbarismo superficial de quem não o leu), são o necessário alargar de horizontes.

E é esse o nosso desejo doutrinal, o de abrir janelas para que possa haver renovação de ar, e mudança de vistas. Janelas para outras paisagens, para outros mundos. 
Os anquilosados e os lunáticos vivem universos paralelos. Eles são por vezes confluentes ou involuntariamente cúmplices - como no rendimento universal garantido, que para os mais quiméricos bem intencionados seria uma cornucópia de abundância para todos (novo "país de cocanha"), talvez por uma suposta redistribuição do grande bolo da acumulação da riqueza, mas para outros, mais céticos, é apenas uma forma sinuosa de se acabar a prazo com a segurança social nas suas mais variadas formas: pois se toda a gente já tem esse rendimento, nada mais de facilidades advindas do Estado. E é óbvio que tal rendimento, em concreto, porque muito baixo (veja-se o salário mínimo português... e é remuneração de trabalho!) não chega. Bom negócio, pois, creem os segundos, para os que são jurados inimigos do Estado social. Para não falar já do desincentivo ao trabalho e na criação de uma mole de (semi)pobres subsidiodependentes, potencialmente uma bomba social como clientelas de demagogia de quem lhes prometa aumento de subsídio (ou, surpreendentemente, o contrário! A massa amorfa reage a tudo e ao seu contrário em situação de populismo narcotizante). E aponte estes ou aqueles bodes expiatórios como culpados pelos males de todos...

De qualquer maneira, aguardam-se mais argumentos de parte a parte... Seja como for, é um exemplo de confluência entre uma cultura anti-trabalho, certamente laxista, e uma cultura meramente economicista, que conta que sempre alguns trabalharão, sendo melhor esvaziar o Estado (ou colocá-lo restritamente ao serviço dos grandes) através de um pretenso igualitarismo muito por baixo... No meio de ambas as perspetivas, certamente há moderados com boas intenções... Nomeadamente se fizeram as contas e chegaram à conclusão de que se pode dar uma espécie de abono de família vitalício. Em que medida seria compatível com o Estado social e o incentivo ao trabalho? Teria o lado negativo da criação de ociosos? É um caso difícil para provar, mas certamente um desafio...

Enfim: uns vivem no passado, no porão, ou na masmorra do castelo interior (que não é obviamente em nada semelhante ao de Santa Teresa de Ávila ${ }^{12}$ ), outros num universo puramente mental, precisamente fechado à realidade. As pessoas meio sonâmbulas entreabrem de tempos a tempos as janelas da sua morada, mas timidamente, só para arejar, numas anuais limpezas na primavera...

Ora a ideia é deixar as janelas abertas. Dormir mesmo de janelas abertas sem medo dos ladrões de sonhos e de bens... Abrir as janelas para abrir as mentalidades.

O sociólogo Gaston Bouthoul estudou bem a categoria sócio-cultural "mentalidades", caracterizadora das sociedades, mas também dos estratos e grupos sociais mais particula-

12 TERESA DE ÁVILA, Santa - Moradas do Castelo Interior. trad., introd. e notas de Manuel de Lucena. Lisboa: Assírio \& Alvim, 1988. 
res, dentro de civilizações e culturas. E começa o seu livro já clássico Les mentalités ${ }^{13}$ precisamente sublinhando como as diferentes mentalidades, desde a Antiguidade, geram antagonismos de hostilidade profundíssimos entre tribos vizinhas que tudo teriam, além disso, para até nem sequer se singularizarem demasiado.

Também hoje as mentalidades e as cada vez maiores divisões de "tribos", mesmo tribos urbanas, enfunadas além do mais pela moda e o consumismo (de vários tipos) contribuem muito para desunir as pessoas, e para as individualizar... Ora sem prejuízo de não se desejar um mundo cosmopolita no mau sentido, sem desinências, sem especificidades, sem localismos, e desde logo sem Línguas específicas e costumes próprios (e Leis que espelhem essas diferenças), é preciso dialogar, é preciso entender os outros. O princípio republicano implica uma universalidade de soluções, e não a eterna desculpa, a eterna exceção, em que, por exemplo em nome de tradições locais ou de grupo, se contrariam leis gerais - atentando contra direitos de mulheres e menores, contra os deveres das pessoas para com os animais, contra interdições de consumo de certas substâncias (quando tal seja justificável), e muitos outros casos. Pascal é sempre citado quanto à diferença que faz, nos conceitos e preconceitos, nos costumes e mesmo nas leis uma mudança de latitude, ou o atravessar um riacho, ou, mais ainda decerto, os Pirenéus ${ }^{14}$. Mas isso implica mudanças de país para país, não dentro de uma mesma ordem jurídica.

A perspetiva de Pascal dá que pensar. Há coisas que tanto o são na Grécia como na Pérsia, como o fogo arder (lembremos agora Aristóteles). Mas há outras coisas que são diferentes na Grécia e noutros lugares. O mesmo Bouthol lembra, com acerto, que o Estagirita não recolheu (aparentemente) as Constituições de muitos países fora da Hélade. Fê-lo para Cartago, e pouco mais, se o fez (como se sabe, perderam-se muitas das Constituições que sociologicamente recolheu com os seus discípulos)... Porque certamente a forma constitucional no sentido mais elevado da Pólis grega era desconhecida daqueles a quem os gregos consideravam barbaroi.

Mas hoje o conceito de bárbaro tem toda uma outra dimensão. O bárbaro é o novo-rico ou o Lumpen no interior das nossas sociedades, não o refugiado, quantas vezes mais culto e letrado que os seus patrões novos-ricos, quando consegue arranjar emprego na Europa. $\mathrm{O}$ bárbaro é o estudante que ostenta essa qualidade (de estudante) só para ter descontos em maus espetáculos e coisas afins e não aproveita a enorme oportunidade que a sociedade e o Estado lhe dão. Que se crê intimamente (e por vezes até o exterioriza) com direito a diploma pela simples matrícula. O bárbaro é o possidente que se sente com direito a explorar sem

13 BOUTHOUL, Gaston - Les mentalités. Paris: P.U.F., 1952.

14 PASCAL, Blaise - Pensées, ed. Brunchvicq. Paris: Garnier, 1925, máx. af. 294. 
dó todos os que lhe venham a cair nas mãos (que acha que, no fundo, o bom seria ter escravos: e alguns quase já o admitem abertamente). O bárbaro é o que procura viver à custa de subsídios, mordomias, esquemas, que recebe roupa limpa de entidades caritativas e não se dá ao trabalho de a lavar: deita-a fora e vai buscar mais roupa, como mais comida, tudo... $\mathrm{E}$ muitos mais.

O problema é, assim, a abertura de mentalidades (a par do discernimento ético e da prática ética). O que tem que ser uma enorme revolução mais que cultural anímica, multidimensional. Enquanto o explorador viver subjugado pela sua ganância, o subsidiodependente e o cábula pela sua preguiça, o laxista pelo seu spleen e amorfismo moral, caminharemos apenas com as pernas e a cabeça de uns tantos, e transportaremos às costas o peso morto de muitos, por estas e aquelas razões. E seremos, continuaremos a ser, sociedades de infelicidade.

Enquanto isso, resistindo, há algumas tábuas de salvação: uma delas é a Ética Republicana, de que falamos bastante no nosso livro Para uma Ética Republicana ${ }^{15}$. A sensação de, contra ventos e marés, cumprir o seu dever, é um bálsamo contra o desconcerto do mundo. Por vezes não há mais nada a fazer do que ficar no único lugar em que não há cedência a terrível corrupção, em que se não violenta a consciência. Sempre vem à lembrança, nestes casos, a ideia de que por vezes nem sequer se trata de heroicidade dos que são inflexíveis numa posição de coerência: por vezes é apenas impossibilidade intrínseca, estrutural, incapacidade de agir de outra forma, por graves que sejam as consequências. Talvez fosse isso que Martinho Lutero queria dizer quando, na dieta de Worms, declarou: "Hier stehe ich. Ich kann nicht anders".

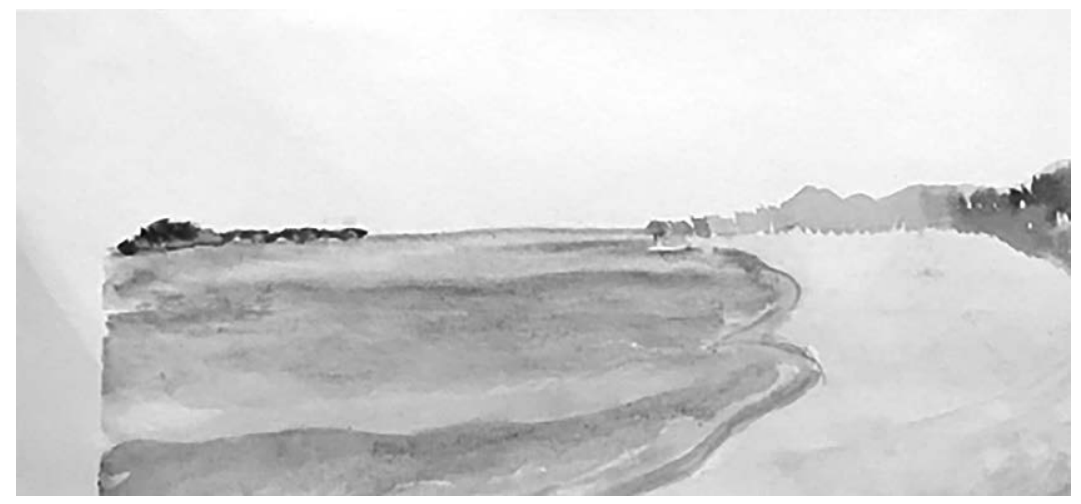

(“Oásis marítimo" - aguarela sobre papel, São Paulo, maio de 2018.)

15 V. o nosso livro Para uma Ética Republicana. Lisboa: Coisas de Ler, 2010. 


\section{Modalidades da Justiça}

Há uma estória popular de um "Frei João sem Cuidados" a quem um rei invejoso (porque cheio de canseiras e preocupações: governar em geral dá trabalho, seja o que for...) um dia tentou encostar à parede com três adivinhas capciosas, mas, graças ao auxílio de um homem livre, um moleiro (os moleiros eram pessoas livres - veja-se o livro de Carlo Ginzburg, O Queijo e os vermes), acabou por confundir o monarca e ver-se livre de apuros.

O cidadão sem cuidados talvez necessite, por vezes, da ajuda de um defensor, de um representante, no fundo, de um advogado, para conseguir livrar-se dos ataques dos poderosos, que não precisam de ser reis para colocarem um bom paisano (ou citadino...) em apuros. Podem ser até marginais com qualquer acesso aos mecanismos da justiça, que conseguem por vezes acionar contra cidadãos de bem - que perdem o seu descuido, de tão estupefactos e confusos que ficam, porque acreditavam que pessoas que cumprem o seu dever não seriam nunca incomodadas com suspeitas e mais ainda que isso... A situação de vulnerabilidade dos cidadãos sem cuidados é digna de especial proteção, porque eles, ao contrário dos infratores profissionais, dos manobristas, dos "videirinhos", e todo um sem-número de categorias de sabidos e desonestos, caem das nuvens da sua ingenuidade e não se sabem defender. $\mathrm{O}$ que pode ser dramático.

O cidadão sem cuidados, em situação normal, ao mesmo tempo dorme bem à noite porque tem a consciência tranquila (isso depende sobretudo de si mesmo), e ainda está em paz com o mundo, porque o mundo lhe não cobra demasiado.

A alma só pode ser recuperada sem o frenesim quotidiano, seja ele laboral(ista), espremendo a força de trabalho até ao tutano, seja o palácio da loucura das burocracias, que tornam a vida do cidadão um instrumental cirandar para nada... para apenas alimentar a máquina da burocracia. E assim fica a pessoa (o cidadão é antes de mais uma pessoa) esgotada, sem propósito, sem vida, sem alma.

As nossas sociedades não são muito propensas à existência de cidadãos sem cuidados. Pelo contrário. Parece que tudo, das complicações laborais às que vivemos por empatia através da comunicação social, passando pelas vidas pessoais cada vez mais vazias, solitárias e conflituosas, tudo contribui para o stress. A Doutrina do choque, de Naomi Klein, é muito eloquente ${ }^{16}$. Parece, na verdade, que vivemos um "capitalismo de desastre", e somos tratados como cobaias com choques elétricos. Somos ensinados a viver crises, cataclismos, débacles... Isso nos mantém docilizados...

16 KLEIN, Naomi - The Shock Doctrine: The Rise of Disaster Capitalism, 2007. trad. port. de Vania Cury. A Doutrina do Choque: A Ascensão do Capitalismo de Desastre. Rio de Janeiro: Nova Fronteira, 2008. 
Fala-se agora em vacina contra o stress, o que é um passo mais no caminho do Brave new world: passando os cidadãos ainda mais à condição de drogados, para poderem ir suportando os fardos.

No oásis marítimo aqui retratado o tempo é nosso. E temos todo o tempo que a vida nos permitir.

Pepe Mujica avisa que ao consumirmos coisas nesta nossa sociedade baseada nesse mesmo consumismo estamos a pagar com tempo de vida: e há um filme notável, O Preço do Amanhã, em que tal troca é desenvolvida e levada aos limites: tudo se paga em tempo de vida).

Evidentemente que a fruição pura à beira mar, olhando o céu e o mar em harmonia, não pode ser para todos, dado que Adão foi condenado ao trabalho. Mas pode haver trabalho compatível com fruição. O problema é o da Justiça na sociedade. Que já era o primeiro problema de Platão, e de onde brota a República, ou Politeia. Vários autores, depois dele, considerarão, com efeito, que a resposta à pergunta sobre a Justiça reside em encontrar o homem justo (será o caso de Santo Agostinho, por exemplo). Mas, sem prejuízo de ser uma verdade (a qual tem evidente atualidade) que não há cidade justa sem homens justos (e daí, num plano religioso - e metaforicamente, decerto, também num plano moral -, que Sodoma e Gomorra pudessem ter sido salvas se nelas houvesse apenas dez justos ${ }^{17}$ ), temos também que dar razão a Platão, ao pensar que o contexto social de Justiça é essencial para que haja pessoas justas. Donde a indagação sobre a Justiça, em Platão, passar a ser, na República, a demanda da sociedade justa. Sabe-se bem que, no confronto entre o ideal e o real, o filósofo da Academia foi descendo a fasquia em subsequentes obras e que a utopia (é, na verdade, uma verdadeira utopia) Politeia, como aliás ocorre mesmo com muitas eutopias (boas utopias, utopias pensadas para serem benéficas), pelo menos aos nossos olhos modernos e liberal-democráticos de hoje não seria uma sociedade tão excelente para se viver. O mesmo se diga, aliás, desde logo, da Utopia de Tomás Moro.

Nunca resolveremos as angústias existenciais profundas de alguns, nunca daremos tudo aos ávidos de universos, nunca estará contente o intrinsecamente mal disposto, é realmente insaciável a sede e fome de poder, de prazer, de riqueza de alguns. A esses uma sociedade justa, harmónica, bem organizada não convém de forma alguma. Mas à esmagadora maioria das pessoas, se bem educadas (não formatadas, não manipuladas, mas mostrando-se-lhes os seus interesses coletivos e individuais bem entendidos), pode satisfatoriamente dar-se cumprimento às suas necessidades fundamentais, estando obviamente nas mãos de cada um ir mais além e ir pelo seu próprio caminho. Mas é possível (e há casos pontuais

17 Gén. XVIII, 32. 
de planos bem sucedidos de justiça social - na saúde, por exemplo, Portugal até está bem cotado, apesar de todos os problemas que o Serviço Nacional de Saúde sofreu) a justiça social.

E num contexto de justiça social também é possivel um trabalho com rosto humano, em que o trabalhador seja protagonista, criador, e não escravo, quaisquer que sejam os eufemismos (ou não) com que pintem a sua nova condição. Aliás agravada pelos meios de permanente controlo e contacto por via das novas tecnologias.

Poder-se-á trabalhar e viver descansado, sem incompatibilidade. O oásis não é uma miragem. Parece, claro, quando há quem advogue que um trabalhador não precisa de mais de 15 minutos para almoçar, e que deve comer uma sandes com uma mão e trabalhar com a outra... Quando até uma horita de intervalo de almoço é regateada a quem trabalha compreende-se o clima de escravatura e de verdadeira exploração para que se caminha, e em que, em grande medida, já se está. Nunca pensamos que estas coisas fossem possíveis no século XX, que fará no XXI. Mas estão a ser. E enquanto isso militantes aguerridos não parecem muito comovidos com estas situações, lateralizando as reivindicações, apontando para o lado... Procurando, em vez de mais igualdade de todos, para todos, e mais fraternidade entre todos, e mais liberdade para todos, abrir feridas, criar novas, barricar grupos, incitar corporativismos, alimentar mal-entendidos e soprar no fole dos conflitos.

Só pode haver direito ao livre desenvolvimento da personalidade com um equilíbrio entre o ser social e o ser pessoal, individual, com uma harmonia entre trabalho e lazer. E as coisas belas, designadamente da natureza, são uma grande ajuda, em todo o caso. São, hoje, em boa medida, um refúgio para quem pode. Mas poderão ser amanhã um bem de fruição geral, livre, para todos... A natureza e a beleza podem ser quase inesgotáveis. Assim as saibamos preservar a uma e cultivar a outra.

Importará finalmente deixar esclarecido que há uma certa higiene mental positiva, salutar, em regressar a Aristóteles (e São Tomás de Aquino, que o retomou) e dividir a justiça em duas (nesta sede, porque há muitas divisões possíveis).

De um lado, está aquela a que chamaríamos "justiça particular, ou jurídica", e que tem como objeto o Direito, que para ela caminha (ou de quem ela é mãe, como diz uma glosa medieval). Essa é a "constante e perpétua vontade de atribuir a cada um o que é seu". O seu (suum) de cada um é que, nela, é o direito, o seu direito de cada qual (suum cuique). Mas evidentemente que os Romanos, que criaram esta descrição lapidar, sabiam bem que, embora tenha de ser uma procura e uma atribuição quotidiana, implica também constante e perpétua vontade: ou seja, nunca se consegue alcançar na plenitude. Tinham, pois, os práticos Romanos a noção da falibilidade e incompletude da Justiça em cada tempo e lugar. A busca do 
suum obriga a indagações técnicas complexas, por vezes, procurando-se o título jurídico que funda o direito (ou a pretensão).

Mas chega-se a breve trecho, se se tiver alguma consciência de Justiça, à conclusão que, se apenas se atribuir a cada um o que lhe venha por título jurídico simples, positivista, o pobre fica pobre e o rico fica rico, e por vezes o pobre cada vez mais pobre e o rico cada vez mais rico. Ou seja, como na sua reflexão sobre a Justiça, no Diário de Alcestes, referiu o filósofo luso-brasileiro Agostinho da Silva, o Direito acabará por ser uma sebe (ou um muro) que dividirá segura (e injustamente) os choros dos risos...

Esta secura positivista do titularismo (mesmo do jusnaturalista) levou a que se incluíssem nos títulos jurídicos a natureza ou condição humana. Evidentemente, é complicado afirmar a existência ontológica da primeira, hoje em dia, depois da antropologia e do existencialismo, segundo alguns, mas é fácil ver que existe uma segunda - veja-se o trabalho de fotografia de Sebastião Salgado. Fiquemos, então, com a simples condição humana, embora suspeitemos que não seja apenas "condição"... Mas não polemizemos agora.

Esta inclusão da condição humana entre os títulos que contribuem para dar alguma coisa a alguém obriga a considerar a dignidade da Pessoa em termos práticos, e e fundamenta rendimentos mínimos garantidos, rendimentos sociais de inserção, enfim, a prestação social pelo Estado de um mínimo de subsistência, assim como serviços públicos mínimos - desde logo de saúde e educação.

A partir desta inclusão (e já pelos exemplos dados de sua concretização, e muitos mais haveria, pelo mundo fora) fica muito fácil compreender que a Justiça Social, que para alguns, mais rigoristas e titularistas (ou simplesmente positivistas legalistas) era uma quimera mais ou menos revolucionária e subversiva, pelo contrário se integra nas dimensões normais da juridicidade. Não se trata de uma perversa ideologização de um Direito pretensamente puro. Trata-se de não tornar o Direito um simples jogo abstrato alheio à Justiça concreta, material, real.

É assim possível e necessário considerar, no Direito, um elemento de Justiça Social, sem prejuízo de ela dever ser também perseguida pelos que, na política, de formas muito diversificadas a procuram. Hoje em dia quase todos, de quase todos os quadrantes ideológicos (menos os fervorosos ditos neoliberais) são a favor de uma qualquer fórmula (há várias, e até politicamente adversas e contraditórias, como explicou na sua admirável tese, Do Estado Liberal ao Estado Social, Paulo Bonavides ${ }^{18}$ ) de Estado social que é a institucionalização de alguma versão de Justiça Social.

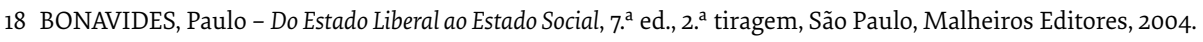


Não deixemos contudo de ver alguma distinção: uma coisa é a dimensão mínima de justiça social implícita na defesa da dignidade da Pessoa humana - e que remete para o título jurídico condição humana - e outra coisa é o anelo, ideologicamente tratável (e aqui ideológico nada tem de pejorativo), em várias perspetivas conforme os credos políticos, de implantação de uma sociedade justa, uma utopia (também no sentido rigoroso e não de quimera ou impossível), ou de aperfeiçoamento da sociedade existente (utopismo ou princípio esperança, de que falava Ernst Bloch, através de várias formas de "reformismo"). Vemos até, felizmente, precedente constitucional de consideração do mínimo de subsistência ou existencial (pouco importa o nome) não, como alguns esperariam, sequer como decorrente de direitos sociais, mas corolário da dignidade da pessoa humana. O que lhe dá, no contexto argumentativo atual, muito maior força.

Na Arte, o titularismo estrito corresponde ao academismo. E reivindicações utópicas desabridas podem ser, em Arte, vanguardismos sem substrato. Contudo, as consequências destes parecem ser mais inócuas que as dos seus homólogos políticos e jurídicos. E estamos em crer que até um excesso vanguardista em Direito poderá ser mais grave, porque primeiro se fazem as revoluções e depois se passam a limpo, juridicamente... Fazer o contrário é perigoso.

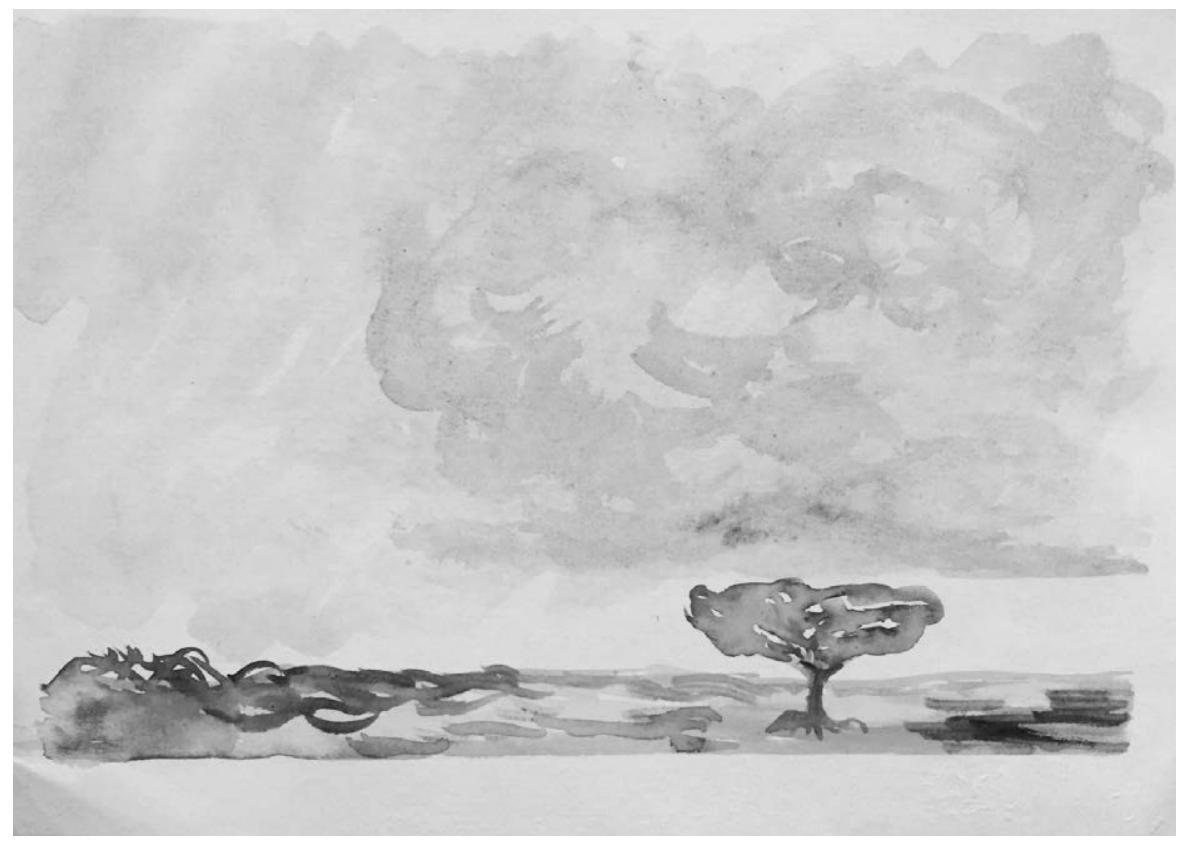

(“Planura" - aguarela sobre papel, São Paulo, maio de 2018). 


\section{Cidadanias}

É muito corrente hoje, em redes sociais, glosar-se Platão, com mais ou menos rigor, na República, para se dizer, afinal, que o preço de alguém se alhear da coisa pública, e especificamente da política, seria ser-se governado, e comandado mesmo, por pessoas de nível inferior.

Aristóteles, na sua Política, discute a questão sobre qual a opção que seria melhor: vida ativa ou vida contemplativa. E embora se veja, pelas suas palavras, que tem a tentação de se quedar pela calma da contemplativa, uma espécie de imperativo categórico lhe impõe a opção pela vida ativa.

Também é hoje corrente fazer alguma tábua rasa sobre o passado clássico e começar essa discussão por uma sem dúvida excelente e mesmo erudita autora, mas que não inventou o problema, naturalmente: Hannah Arendt ${ }^{19}$. Especialmente remetendo para o seu livro A Condição Humana, e o seu conceito de vita activa, que daria afinal título a um muito interessante filme sobre a autora ${ }^{20}$ :

Outras vozes se poderiam recordar, como é óbvio. O problema afigura-se-nos ter a ver com a fé na capacidade de intervenção no mundo. Não se trata, como para os desportistas ou os ginastas amadores, ou os que querem perder peso ou aumentar endorfinas, de correr por correr, de se agitar ou intervir por intervir - já que sabem que as consequências necessárias da atividade serão para si positivas. A ação, no campo social, político, jurídico, não tem um valor por si (nem de forma alguma garantido), a menos naqueles casos em que é preciso marcar ponto (ou "ditar para a ata") na História para "salvar a alma".

Vale mais uma vida em esfalfar-se permanente sem resultados, ou uma vida bem vivida, com afetos, com qualidade, com confortos, com diálogos, com fruição da natureza e da cultura, e mesmo, para alguns (e deve dizer-se que são hoje cada vez mais, certamente), de comparticipação, cada uma ao seu nível, na cultura e no cuidado com a natureza (que afinal representam uma outra forma de militância e de intervenção: mas mesmo que o sejam de forma leve, souple...)? Posta a questão assim, parece que a primeira se resume a um esgrimir com moinhos de vento, ou com máquinas de guerra tão possantes, ou fortalezas tão inexpugnáveis que a derrota é certa, e daí a imprestabilidade do esforço despendido.

Diríamos então que o grande problema é de vocação. Há um chamamento a ser-se atacante no jogo, ou a preservar-se a retaguarda. A ser-se audacioso como Tomás Moro ou Boécio (embora ambos de uma audácia sempre prudente) ou a ser-se preservador de legados, como Cassiodoro. Quem tem a vontade e a compulsividade da vida ativa, como poderá

19 Sobre a autora, desde logo, por todos, LAFER, Celso - Hannah Arendt. Pensamento, Persuasão e Poder, 2. ${ }^{a}$ ed., São Paulo, Paz e Terra, 2003.

20 Vida Ativa - O Espírito de Hannah Arendt, de Ada Ushpiz, 2015. 
recolher à poltrona e ao cachimbo, fumando congeminações? Quem, pelo contrário, se afoba com as ágoras, se aborrece de morte com as arengas sem propósito de tantos discursos demagógicos, se envenena com o acúmulo de intrigas que há que suportar, deslindar e contra-atacar na política, seja na global e macro-, seja na particular ou micro-, certamente apenas por um imperativo categórico muito categórico e muito imperativo se leva a entrar na atividade cívica mais empenhada.

Claro que a uma pessoa com um perfil mais contemplativo, calma, ponderada, moderada, não repugnará de todo dar o seu avalizado parecer num conselho civilizado, com pares educados, ou algo semelhante. Mas atirar-se para o campo aberto e desprotegido da batalha sem rede, sem garantias, sem escudo até, só no caso de ter tocado a rebate um carrilhão de liberdade ou afim, que obriguem a sua consciência. Mais lhe acaba por convir uma espécie de cidadania passiva, de votante, de (no máximo) subscritor de petições (hoje, aliás, banalizadíssimas), etc..

Acresce ainda que as instituições de uma democracia nem sempre são instituições democráticas. E mesmo, por exemplo, os partidos, os sindicatos, as associações políticas, etc., nem sempre nem em todos os países são modelos de democracia interna. Desde logo, poder-se-á invocar, a este propósito, a chamada lei de bronze das oligarquias, e muito especificamente das oligarquias partidárias, de que foi estudioso pioneiro Robert Michels, já no seu livro sobre os partidos, dos inícios do século $\mathrm{XX}^{21}$.

Isto significa que o bom cidadão entusiasta, que tenha pretensões a ser mais que um colador de cartazes numa instituição de luta pelo poder (e hoje essa tarefa já está terceirizada e sintetizada em apelativos outdoors profissionalmente concebidos e tratados), mesmo com muitos dotes técnicos, empenhamento de fé no credo ideológico respetivo (se o houver) ou fidelidade aos líderes (se existirem com suficiente carisma), com tempo (essencial para investir neste tipo de tarefas) não tem de modo algum garantido que a sua participação seja tida em conta, que o seu contributo seja considerado. Pode, se for simpático e se forem simpáticos consigo, receber sorrisos, palmadas nas costas e um ou outro elogio. Mas a possibilidade de passar a barreira da adesão para a possibilidade de ação e vero protagonismo, mais que explicável por insondáveis teorias da conspiração ou complexos algoritmos das novas ciências, parecem-nos apenas decifráveis pelo mistério profundo da Fortuna, a velha deusa da sorte. Há quem tenha sorte e quem não tenha sorte na política. Assim como no jogo ou nos amores... São sinas. Não depende muito do valor, da inteligência, nem sequer da militância. Esta é uma espécie de bilhete mínimo para a grande tômbola dos "chamados"

21 Entre nós publicado como: Para uma sociologia dos partidos políticos na democracia moderna: investigação sobre as tendências oligárquicas na vida dos agrupamentos políticos, Lisboa, Antígona, 2000. 
e dos "escolhidos", mas não garante mais que uma vaga possibilidade de participação. E mesmo quem não milite pode, sabe-se lá por que milagre, vir a ser chamado, e normalmente para alto cargo. Talvez nesses casos a visibilidade mediática ou em círculos de poder, fama, negócios, e afins rodas de elites supram, e supram muitas vezes com vantagem, o "dar o litro" dos velhos "coladores de cartazes".

A planura contemplativa da imagem que ilustra este texto remete para um outro mundo, o de uma vida privada, embora ao ar livre (não enclausurada nem ensimesmada). Contudo, ela não está isolada do mundo em geral. Por um lado, o solo em que a árvore se implanta tem seus laivos de revolta, não é total planura. Por outro, o céu apresenta uma certa ameaça de chuva, nos tons violáceos-cendrados que esboça. Entre um solo que pode não ser completamente plácido, e um céu que sugere ameaça, é essa, sempre, a sina da vida contemplativa da árvore altiva, com raízes fundas e copa orgulhosa. Há uma fragilidade na vida privada. Como há um risco na vida pública. Como pode haver frustração na tentativa de participação pública frustrada.

Não há perfeição no Mundo. Não há um caminho apenas, e muito menos uma senda segura.

Não nos esquecemos de não estigmatizar nem o militante puro nem o pacato votante, cidadão "passivo". Ambos podem exercer uma boa cidadania, cada um à sua maneira. E quanto ao dito "passivo", quão salutar e com que positivas influências não será o seu distante e sábio voto, quando vota em consciência e com consciência reta, pelo bem comum?

Entretanto, nos nossos dias há a assinalar também militâncias estranhas, que podem ser alheias às grandes causas sociais de sempre, mas que elegeram apenas nichos do mercado da contestação. Há casos e casos. Alguns de uma bizarria que para alguns será ridícula, outras com pertinência. Não se pode senão analisar caso a caso. Contudo, este tipo de movimentações perturbadoras dos cânones mais tradicionais já têm sido alvo de críticas (embora raramente, cremos que por pressão do politicamente correto, em que se enquadram). As mais interessantes serão aquelas que, como as de alguns comentadores políticos conhecidos, as causas contra corridas de touros ou tabagismo distraem de bandeiras mais urgentes e mais importantes socialmente.

Há ainda medidas claramente discriminatórias de certos grupos ou privilegiadoras de outros, que colocam o debate político e a decisão jurídica e administrativa, por vezes, entre paralelogramos de forças meramente corporativas. Sendo de ter o maior cuidado em discernir quais dessas causas têm relevância social geral, e quais são simplesmente jogos de interesses, camuflados por grandes parangonas e marketing para impressionar a opinião pública e os decisores. 
Não parece, contudo, que a cidadania, quer ativa, quer passiva, se encontrem em boas condições para fazerem hoje um juízo avisado e prudente destes vendavais de novidades reivindicativas (algumas comportando ou trazendo no ventre revoluções inimagináveis ainda), porquanto a formação do sentido crítico necessitaria de uma outra Escola, de uma outra Comunicação social e mesmo de uma Família mais consciente e ativa, todas mais empenhadas nesse fim. Sem tais vetores renovados somos, a maioria de nós, completamente reféns das modas, dos rumores, das manipulações mediáticas.

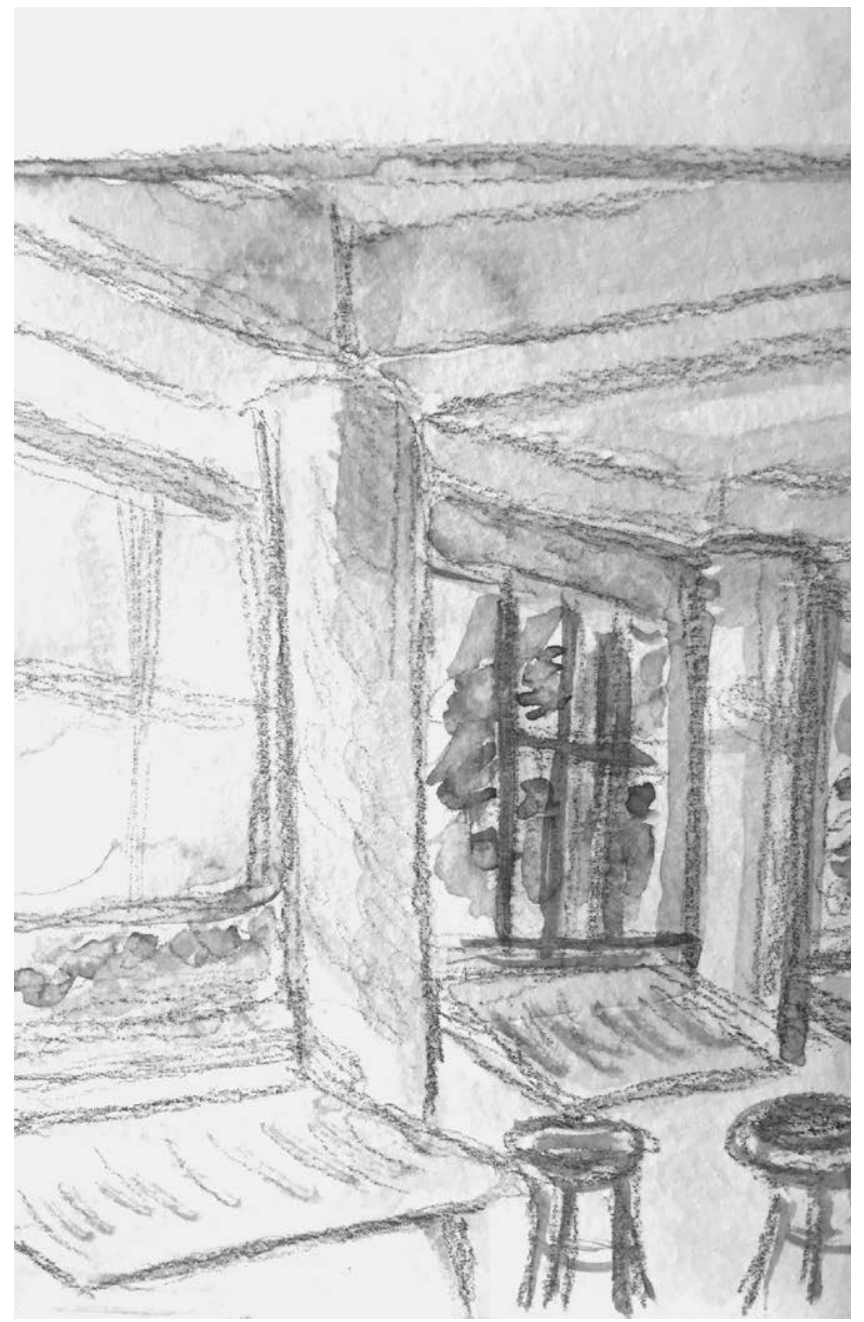

"Sala do Risco" - grafite e aguarela sobre papel - Porto, maio de 2018. 


\section{Riscos, Vitórias, Deontologias}

Casa dos contos, sala do risco, e tantos outros, são nomes mágicos que tinham instituições e lugares antigos, que não vamos aqui desvendar para os não privar do encanto e sabor. Hoje alguns deles foram adaptados a situações e empreendimentos modernos, naturalmente seduzidos pela graça e profundidade das suas metáforas.

O que queremos dizer com o título deste apontamento de uma sala das Belas Artes do Porto, visto à nossa maneira, é a função da sala apenas: riscar. Mas riscar assumindo riscos. Porque criar é isso, sempre. Riscar, pois, no risco. Fazer do risco um risco. Aposta, possibilidade, jogar a cabeça. E jogar a cabeça, arriscar tudo, já nos remete para etimologias gregas de palavras ligadas à governação, ao reinar. O que reina joga a cabeça, põe a cabeça no cepo.

A Arte também tem muitas decisões a tomar, e em cada uma a obra pode perigar. O risco é comum à política e à arte.

O Direito interiorizou muito a ideia de risco (que estava já esparsa em várias temáticas de responsabilidade, crime, etc.) ao ir beber nas perspetivas sociológicas de Ulrich Beck, que chegam a caracterizar a sociedade atual como "sociedade de risco" (Risikogesellschaft) ${ }^{22}$. Podemos dizer que espadas de Dâmocles várias impendem sobre as nossas cabeças, mas a eutopia, a utopia positiva, não deveria ser perdida de vista: uma sociedade não de plácida e aborrecida segurança sem aventura. Mas aventura com muita segurança, apesar de tudo.

O mundo moderno vende pacotes de aventuras, enaltecem-se desportos mais ou menos radicais. Há contudo, para além do lúdico, de perigos que se enfrentam pelo simples propósito de fazer subir a adrenalina ou de ganhar um qualquer fútil troféu, há contudo, realmente, muitas aventuras que valem a pena, que comportam risco, e que, no perigo, garantem a glória verdadeira aos que conseguem vencer (para glosar um dito de Corneille).

Portanto, e seguindo o autor do Cid, para haver glória é preciso que o triunfo tenha conseguido vencer o perigo (A vaincre sans péril on triomphe sans gloire). Mas decerto no tempo dele não seriam tão frequentes as gloríolas fátuas de coisas perigosas sem propósito... Que sabemos nós?

Um outro requisito haverá, assim, a acrescentar, seja como for: a glória só pode advir de um perigo corrido com interesse, com importância, por uma causa nobre, importante, e por um motivo virtuoso. Assim, está completamente certa a canção Victime de ma victoire: "A vaincre sans vertu on triomphe sans gloire"23.

Como essa questão se coloca no Direito! Ganhar uma causa por ínvias vias? Aceitar um caso duvidoso? Aceitar defender um facínora? - questões clássicas para aprendizes de juristas,

22 BECK, Ulrich - Risikogesellschaft, Francoforte-sobre-o-Meno, Suhrkamp,1986.

23 Da ópera rock Mozart (Dove Attia / Albert Cohen, 2009). 
que os grandes autores da deontologia, de Maurice Garçon a Rafael Gómez Perez e em Portugal António Arnaut, por exemplo, facilmente dilucidaram já24.

Há sempre, contudo, um pequeno aguilhão da consciência, em certos hard cases ${ }^{25}$. E qualquer causa pequena pode tornar-se deontologicamente num caso difícil. Pode haver grandes vitórias de causídicos ou do Ministério Público e outras magistraturas, nos países em que existem, sem perigo, sem dificuldade? Cremos ser difícil. E poderá havê-las com infração de regras deontológicas, com malas artes? Jamais poderá ocorrer.

Evidentemente que essas malas artes podem ser ocultas e de tal forma sinuosas e na sombra que ninguém se dê delas conta, e o(s) jurista(s) em causa (ou sua causa) possa(m) vir até a tornar-se celebradíssimo(s). Não deixa, porém, de ser um caso de consciência complexo o advogado de um inocente, por exemplo, ter de enfrentar o dilema de cometer alguma irregularidade salvando quem deve ser salvo ou não a cometer, condenando-o. Há casos limite em que talvez a honra e a alma do advogado sejam sacrificados para que a Justiça, uma Justiça aparentemente maior, possa triunfar. Mas são daquelas situações que nos deixam incomodados e com vontade de não ser jurista e ter esses problemas, mas por exemplo artista, cujos dilemas especificamente na sua arte (não na dimensão comercial e política da mesma, está claro) ocorrem de forma muito mais plácida. As angústias artísticas soem ser outras. Em luta com o material, com a expressão, com a ideia, com a forma, consigo mesmo...

E contudo, em tempos de subida de autoritarismos e candidatos a totalitarismos, como os nossos, já está claro que a Arte corre riscos. Primeiro de proibição e censura. Depois de sevícias sobre os artistas. E já, certamente, em muitos casos, dessa perversa autocensura daqueles que, para sobreviver ou triunfar, já só produzem o que creem agradar aos vários poderes que decidem, e distribuem os prémios (e as punições, em tempos mais negros). Porém, também é sabido que, como dizia Alain, "pensar é dizer não", e há sempre alguém que o diz, mesmo nos tempos mais tristes. como cantou Manuel Alegre. Ou seja, há sempre quem pense e quem tenha coragem. E isso redime a Arte e a própria natureza ou condição humanas.

24 GOMEZ PEREZ, Rafael - Deontología Juridica, Pamplona, EUNSA, 1982; ARNAUT, António -Iniciação à Advocacia, 8. ${ }^{\mathrm{a}}$ ed. refundida, Coimbra, Coimbra Editora, 2005.

25 A contrario, v.g., HOVEN, Paul Van Den - Clear Cases: Do they Exist?, in "Revue Internationale de Sémiotique Juridique / International Journal for the Semiotics of Law“, Vol. III, n. ${ }^{\circ}$ 7, 1990, pp. 55-63. 


\section{BIBLIOGRAFIA}

ALVES, João Lopes - Rousseau, Hegel e Marx. Percursos da Razão Política. Lisboa: Livros Horizonte, 1983.

ARNAUT, António -Iniciação à Advocacia, 8. a ed. refundida, Coimbra, Coimbra Editora, 2005.

BARROS, Gilda Naécia Maciel de - Agraphoi Nomoi. São Paulo: "Notandum", vol. 3, ed. online: http://www. hottopos.com/notand3/agrafoi.htm. Ultimamente consultado em 29 de agosto de 2018.

BECK, Ulrich - Risikogesellschaft, Francoforte-sobre-o-Meno, Suhrkamp,1986.

BONAVIDES, Paulo - Do Estado Liberal ao Estado Social, 7. ${ }^{\mathrm{a}}$ ed., 2. ${ }^{\mathrm{a}}$ tiragem, São Paulo, Malheiros Editores, 2004.

BOUTHOUL, Gaston - Les mentalités. Paris: P.U.F., 1952.

ENGELS, Friedrich - A Origem da Família, da Propriedade Privada e do Estado. n/ ed. trad. port. de H. Chaves. Lisboa: Presença, s.d..

ÉSQUILO / SÓFOCLES - Tragiques Grecs. Eschyle / Sophocle. Paris: Gallimard, 1967.

FERREIRA DA CUNHA, Paulo - Para uma Ética Republicana. Lisboa: Coisas de Ler, 2010.

—, Le Droit et les Sens. Paris: L'Archer, dif. P.U.F., 2000.

—, O Ponto de Arquimedes. Natureza Humana, Direito Natural, Direitos Humanos, Coimbra, Almedina, 2001.

FINKIELKRAUT, Alain - Un Coeur intelligent. Lectures. Paris: Stock/Flammarion, 2009.

GOMEZ PEREZ, Rafael - Deontología Juridica, Pamplona, EUNSA, 1982.

HAYEK, F. A. - Droit, législation et liberté. I - Règles et ordre, trad. fr.. Paris : PUF, 1973.

HOVEN, Paul Van Den - Clear Cases: Do they Exist?, in "Revue Internationale de Sémiotique Juridique I International Journal for the Semiotics of Law“, Vol. III, n. ${ }^{\circ}$ 7, 1990, pp. 55-63.

KLEIN, Naomi - The Shock Doctrine: The Rise of Disaster Capitalism, 2007. trad. port. de Vania Cury. A Doutrina do Choque: A Ascensão do Capitalismo de Desastre. Rio de Janeiro: Nova Fronteira, 2008.

LAFER, Celso - Hannah Arendt. Pensamento, Persuasão e Poder, 2. ${ }^{\text {a }}$ ed., São Paulo, Paz e Terra, 2003.

MALTEZ, José Adelino - Voegelin e a Procura do Direito Natural, Prefácio a A Natureza do Direito e outros textos jurídicos, de Eric Voegelin. Lisboa: Vega, 1998.

MICHELS, Robert - Para uma sociologia dos partidos políticos na democracia moderna: investigação sobre as tendências oligárquicas na vida dos agrupamentos políticos, Lisboa, Antígona, 2000.

MORGAN, Lewis H. - Ancient Society, or researches in the lines of Human Progress from Savagery through Barbarism to Civilization. Londres: Mac Millan, 1877.

PASCAL, Blaise - Pensées, ed. Brunchvicq. Paris: Garnier, 1925, máx. af. 294.

ROUSSEAU, Jean-Jacques - Oeuvres Complètes. Paris: Seuil, 1971, 3 vols.. Contrato Social e o Discurso sobre a origem e os fundamentos da desigualdade entre os homens. trad. port., Porto: Athena, 1964.

TERESA DE ÁVILA, Santa - Moradas do Castelo Interior. trad., introd. e notas de Manuel de Lucena. Lisboa: Assírio \& Alvim, 1988.

TOMÁS DE AQUINO - Summa Theologiae, trad. fr., Somme Théologique. Paris: Cerf, 1984-86, 4 vols..

TZITZIS, Stamatios - Introduction à la philosophie du droit. Paris: Vuibert, 2011.

—, La Formation du droit en Grèce, in Instituições de Direito, org. nossa, vol. I, Coimbra : Almedina, 1998, p. 191 ss...

— L L Pailosophie Pénale. Paris: P.U.F., 1996, trad. port., notas e comentários de Mário Ferreira Monte. Filosofia Penal. Porto: Legis, 1999. 


\title{
A utilização de novas tecnologias no âmbito da investigação criminal e as suas limitações legais: a interceptação de comunicações em massa e os softwares de espionagem
}

\author{
The use of new technologies in criminal investigations \\ and their legal limitations: interception of mass communications \\ and espionage software
}

\section{EDUARDO BOLSONI RIBOLI'}

GALILEU - REVISTA DE DIREITO E ECONOMIA · e-ISSN 2184-1845

Volume XIX $\cdot 1^{\text {st }}$ July Julho $-31^{\text {TH }}$ December Dezembro $2018 \cdot$ pp. 49-77

DOI: https://doi.org/10.26619/2184-1845.XIX.2.3

Submited on Submitted on October $04^{\text {th }}, 2018$. Accepted on November $11^{\text {th }}, 2018$

Submetido em 4 de Outubro, 2018 . Aceite a 11 de Novembro, 2018

RESUMO O presente estudo tem como finalidade analisar a problemática relacionada à utilização de novas tecnologias no âmbito da investigação criminal, em particular novos métodos ocultos de investigação como a interceptação de comunicações em massa e os softwares de espionagem, e os requisitos necessários para conferir legitimidade à aplicação destes novos recursos, de modo a impedir arbitrariedades das autoridades responsáveis pela investigação e garantir a proteção dos direitos fundamentais e das liberdades individuais do indivíduo investigado.

PALAVRAS-CHAVE interceptação de comunicações, método oculto de investigação, meio oculto de obtenção de prova, software de espionagem, malware.

ABSTRACT This paper aims to examine the problems related to the use of new technologies in criminal investigations, in particular new hidden investigation methods such as the interception of mass communications and spying software. It analyses the necessary requirements to confer legitimacy to the use of these new resources in order to prevent the arbitrariness of the investigating authorities and to ensure the protection of the fundamental rights and individual freedoms of the investigated individual.

1 Doutorando em Direito (Especialidade de Ciências Jurídico-Criminais) pela Universidade de Lisboa. Mestre em Ciências Jurídico-Criminais pela Universidade de Coimbra. Membro, bolseiro do FCT, do Ratio Legis - Centro de Investigação e Desenvolvimento em Ciências Jurídicas, da Universidade Autónoma de Lisboa. 
A utilização de novas tecnologias no âmbito da investigação criminal e as suas limitações legais...

EDUARDO BOLSONI RIBOLI

KEYWORDS communications interception, hidden method of investigation, hidden means of obtaining evidence, spying software, malware

\section{Introdução}

Detentores de um indiscutível valor social, os avanços tecnológicos ampliaram e agilizaram os canais de comunicação, revolucionando, assim, a circulação de pessoas, de bens e de informação. Vivemos hoje na designada "sociedade da informação"2, cujas características definidoras consistem no fluxo constante de informação e conhecimento como recursos fundamentais e que desempenham papéis centrais na orientação do comportamento social, em especial mediante o uso de sistemas informáticos e de ferramentas como a Internet, Facebook, Wikipedia, LinkedIn, Twitter etc.

A evolução e a proliferação dos canais de comunicação, dos sistemas informáticos e dos dispositivos eletrônicos, aliadas à rapidez e à facilitação do anonimato em ambiente digital, acabaram também por estimular o desenvolvimento de novas atividades criminais. Com efeito, não só a sociedade em geral foi paulatinamente se mundializando e moldando pela rápida troca de fluxos de informação, como também a criminalidade se adaptou às novas condições, adotando formas mais organizadas, internacionalizadas e informatizadas. Novas práticas delitivas foram originadas - especialmente aquelas ocorridas em ambiente digital, os chamados cibercrimes -, acompanhadas por novos meios para a consumação de ilícitos penais tradicionais, os quais, em muitos casos, tiveram sua prática facilitada (v.g. crimes de terrorismo, crime de pornografia de menores e delitos de tráfico de estupefacientes e de pessoas). Esta mencionada facilidade para a prática de ilícitos penais em ambiente digital contrasta com a dificuldade acrescida com que se deparam os órgãos de perseguição penal na identificação do fato criminoso e dos agentes envolvidos, na realização de investigações em escala global e no combate a estas práticas ilícitas. Neste cenário global digital, não restam dúvidas de que a ameaça do terrorismo e de crimes graves (mormente o tráfico de estupefacientes, o tráfico de seres humanos e a exploração e tráfico de menores) são perigos reais e imprevisíveis em qualquer Estado.

Tamanha (r)evolução apresenta incontáveis novos desafios para os órgãos policiais, para as autoridades judiciais e para o sistema jurídico de cada país, especialmente no

2 Cf. VERVAELE, J. A. E, - Surveillance and Criminal Investigation: Blurring of Thresholds and Boundaries in the Criminal Justice System?. In: Reloading Data Protection: Multidisciplinary Insights and Contemporary Challenges. Dordrecht, Heidelberg, London, New York: Springer, 2014, pp. 118-119. 
campo da recolha da prova penal. A ameaça do terrorismo, a proliferação de medidas antiforenses $^{3}$ (como a criptografia ${ }^{4}$ ) e a própria infraestrutura das (novas) tecnologias de comunicação ${ }^{5}$ desafiam o modo como as autoridades policiais e judiciais operam em matéria de investigação criminal. Na verdade, os novos obstáculos apresentados à investigação pela criminalidade tecnologicamente engajada decorrem mais das tecnologias utilizadas pelos criminosos do que das novas práticas ilícitas - exclusiva ou maioritariamente em ambiente digital - criadas. São os novos dispositivos eletrônicos e sistemas informáticos assimilados pela criminalidade que obstaculizam a persecução penal, mas que também podem a facilitar.

Os métodos tradicionais de obtenção de prova mostram-se cada vez mais inadequados ${ }^{6}$ para contornar os óbices decorrentes da evolução tecnológica. A criptografia, a ocultação de dados, a destruição de informações, as diferentes rotas de comunicação na Internet etc. atualmente demandam uma atuação muito mais incisiva dos órgãos responsáveis pela investigação criminal - guardada a gravidade do ilícito, evidentemente, em respeito aos princípios a serem observados em matéria de métodos ocultos de obtenção de $\operatorname{prova}^{7}-$, exigindo também a assimilação e aperfeiçoamento de tecnologias investigativas pelo Estado no exercício do seu poder punitivo. Já não basta unicamente interceptar uma comunicação, o seu conteúdo pode estar encriptado. Já não basta apreender um computador, o seu con-

3 Técnicas e/ou programas informáticos que ocultam a identidade de um indivíduo e a informação por ele transmitida ou a ele enviada via telecomunicação, bem como os dados armazenados em um sistema informático ou dispositivo eletrônico (CONLAN, Kevin; BAGGILI, Ibrahim; BREITINGER, Frank - Anti-forensics: Furthering digital forensic science through a new extended, granular taxonomy. In Digital Investigation. Amsterdam, New York. ISSN 1742-2876. v. 18 (Supplement), 2016, p. 566).

É importante destacar que a utilização de medidas antiforenses não implica necessariamente a predisposição à prática de crimes, elas podem ser empregadas simplesmente para assegurar a privacidade do indivíduo, e de terceiros, para fins lícitos. As medidas antiforenses servem, por vezes, até mesmo como uma ferramenta de segurança contra crimes que ocorrem por meio de sistemas informáticos, protegendo o usuário comum da criminalidade em ambiente digital.

4 Técnica que transforma um texto simples em um formato obscuro, codificado, através da utilização de um algoritmo matemático, tornando a informação ilegível a terceiros (esta somente pode ser acessada, tornando-se legivel, ou descriptografada, pelo destinatário da informação) (GERCKE, Marco - Understanding Cybercrime: A Guide for Developing Countries. Geneva: International Telecommunication Union, 2011, p. 146).

5 Uso de computação em nuvem, sistemas de comunicação via fibra óptica e a conexão à Internet através de uma rede sem fios são exemplos de tecnologias que impõem óbices à atividade investigativa (POOL, R. L. D.; CUSTERS, B. H. M - The Police Hack Back: Legitimacy, Necessity and Privacy Implications of The Next Step in Fighting Cybercrime. In European Journal of Crime, Criminal Law and Criminal Justice. Deventer. ISSN 0928-9569. V. 25, N. ${ }^{\circ}$ 2, 2017, p. 130).

6 Como a obtenção de informações em ambiente digital, um espaço que desafia métodos tradicionais de colheita de prova por não alcançarem os dados contidos em sistemas informáticos e aparelhos eletrônicos. Essa foi uma das razões que levaram o legislador português a editar a Lei n. ${ }^{\circ}$ 109/2009, de 15 de Setembro (autointitulada "Lei do Cibercrime"), a qual incluiu no ordenamento jurídico português novos meios de obtenção de prova na tentativa de superar os desafios impostos no ambiente digital.

7 Catálogo de crimes, indícios de suspeita, subsidiariedade, proporcionalidade, requerimento do órgão acusador e autorização judicial, posterior notificação ao investigado, por exemplo. 
teúdo pode ter sido encriptado ou eliminado automaticamente. Já não basta ativar o GPS de um smartphone para determinar a sua localização, as coordenadas podem ser fictícias.

Destarte, os Estados necessitam de ponderar sobre a eficácia dos meios de obtenção de prova à disposição em seu ordenamento jurídico e de idealizarem novas formas de obtenção de prova capazes de ultrapassar os desafios erigidos pelas evoluções decorrentes da sociedade mundializada da informação, de modo a cumprir o seu dever de zelo pela segurança dos seus cidadãos, e, ao mesmo tempo, o dever de zelo pelos direitos e garantias fundamentais dos indivíduos investigados.

A necessidade de superação das inadequações reveladas pelos métodos de obtenção de prova convencionais faz surgir novos instrumentos de investigação criminal, capazes de alcançar de modo rápido e eficaz informações em patamares - tanto em abrangência quanto em intromissão à direitos e garantias fundamentais - nunca antes vistos, porém a grandes custos, como ocorre nos casos que serão analisados no presente estudo.

\section{Dos métodos ocultos de investigação criminal}

É a partir deste cenário de evolução tecnológica, de assimilação de novas tecnologias por criminosos e de necessidade de criação de ferramentas eficazes para fins investigativos que ganham relevo os chamados métodos ocultos de investigação - métodos de obtenção de prova efetuados sem o conhecimento do indivíduo investigado ${ }^{8}$-, devido à sua capacidade de obtenção de informações dificilmente alcançáveis pelos métodos tradicionais e, dependendo da tecnologia empregada, de colheita de dados previamente a tentativas de sua ocultação ou destruição. Proliferam nesse contexto o uso de interceptações de comunicações (escutas telefônicas, intromissão no correio eletrônico, escutas online, por exemplo), recurso a agentes encobertos, videovigilância, gravações ambiente e localização por GPS.

Diante da evidente possibilidade de restrição de diferentes direitos fundamentais (intimidade da vida privada, inviolabilidade de domicílio, das telecomunicações ou da correspondência, entre outros), os métodos ocultos de investigação são reconhecidos por sua excepcionalidade. Com efeito, tratam-se de medidas que dependem de previsão legal;

8 "[O]s métodos ocultos de investigação representam uma intromissão nos processos de acção, interacção e comunicação das pessoas concretamente visadas, sem que estas tenham conhecimento do facto nem dele se apercebam. Que, por causa disso, continuam a agir, interagir, a expressar-se e a comunicar de forma 'inocente', fazendo ou dizendo coisas de sentido claramente auto-incriminatório ou incriminatório daqueles que com elas interagem ou comunicam. De forma simplificada e reducionista, os meios ocultos de investigação levam as pessoas atingidas - normalmente o suspeito - a 'ditar' inconscientemente para o processo 'confissões' não esclarecidas nem livres" (ANDRADE, Manuel da Costa - "Bruscamente no Verão passado", a reforma do código de processo penal: observações críticas sobre uma lei que podia e devia ter sido diferente. Coimbra: Coimbra Editora, 2009, pp. 105-106). 
da demonstração da necessidade de sua aplicação (dificuldade de obtenção da prova e/ou esgotamento de outras medidas); e de um juízo de proporcionalidade entre os interesses da Justiça e a restrição de direitos individuais ${ }^{9}$. Em Portugal - por força da interpretação conjunta dos artigos $18 .^{\circ}$, n..$^{\text {s }} 3$ e 2 , e $32 .^{\circ}$, n. $^{\circ} 8$, todos da Constituição da República Portuguesa, e dos artigos $125^{\circ}, 126 .^{\circ}$, n. ${ }^{\circ}$, ambos do Código de Processo Penal - os métodos ocultos de investigação são reconhecidos como "métodos relativamente proibidos" ${ }^{10}$ de prova, os quais reclamam uma robusta, clara e densa previsão legal. A sua regulamentação não deve se ater unicamente à observância aos princípios e às disposições da ordem jurídica nacional e supranacional, os métodos relativamente proibidos de prova requerem previsão legal densa suficiente para que haja a menor restrição possível a direitos fundamentais, tão mais densa quanto mais intrusiva a direitos individuais for a medida, principalmente quando se tratar de um método oculto de investigação.

Destarte, a assimilação de novas tecnologias para fins investigativos somente encontrará legitimidade mediante uma regulamentação dotada de qualidade. Essa é uma das problemáticas centrais em tema de métodos ocultos de investigação, questão que analisaremos a seguir ao estudarmos a interceptação de comunicações em massa, a partir do entendimento do Tribunal Europeu dos Direitos do Homem, e o uso de software de espionagem para fins investigativos.

\section{A interceptação de comunicações em massa e o caso BIG BRother WATCH AND OTHERS V. THE UNITED KINGDOM}

No dia 13 de setembro de 2018, o Tribunal Europeu dos Direitos do Homem julgou o caso Big BRother WATch AND Others V. THE UNited KingDom, no qual enfrentou o tema da conformidade do ordenamento jurídico do Reino Unido com a Convenção Europeia dos Direitos do Homem, em específico o programa de interceptação em massa do Reino Unido; a regulamentação sobre a partilha entre países e territórios estrangeiros de dados obtidos por agências de inteligência; e a regulamentação sobre a obtenção de dados de comunicações de provedores de serviços de comunicação.

9 MENDES, Paulo de Sousa - Lições de Direito Processual Penal. Coimbra: Almedina, 2015, p. 188 e ss.; ANDRADE, Manuel da Costa - "Bruscamente no... cit., p. 105 e ss; ANDRADE, Manuel da Costa - Sobre as proibições de prova em processo penal. 1. ${ }^{a}$ ed. (reimpr.). Coimbra: Coimbra Editora, 2013, pp. 117-132, 209 e ss.; RODRIGUES, Benjamim Silva - Da Prova Penal - Tomo II - Bruscamente... A(s) face(s) oculta(s) dos métodos ocultos de investigação criminal. Cascais: Rei dos Livros, 2010, passim; VALENTE, Manuel Monteiro Guedes - Processo penal - Tomo I. $3 .^{a}$ ed., ver., actual. e aument. Coimbra: Edições Almedina, 2010, p. 448 e ss.

10 MENDES, Paulo de Sousa - Lições de Direito... cit., p. 180. 
Trata-se de uma decisão paradigmática em matéria de investigação criminal, com o potencial de impactar de maneira significativa programas de vigilância de diferentes países, em especial Estados europeus, bem como os seus ordenamentos jurídicos no que diz respeito ao regime de interceptação de comunicações.

O caso Big BRother Watch AND Others V. The UNited KingDom diz respeito ao julgamento, em conjunto, de três queixas interpostas contra o REINo UNIDo pelos requerentes BIG BROTHER WATCH (organização britânica, apartidária e sem fins lucrativos, de proteção às liberdades civis e à privacidade), ENGLISH PEN (entidade filantrópica que promove a liberdade de expressão), OPEN Rights GROUP (organização britânica de proteção e preservação dos direitos e liberdades digitais) e CoNSTANZE KuRZ (especialista em vigilância digital e porta-voz do grupo alemão "Computer Chaos Club", o qual realiza campanhas para ressaltar fragilidades em redes e programas informáticos que coloquem em risco interesses públicos, como o direito à privacidade) (queixa n. ${ }^{\circ} 58170 / 13$ ); BUREAU OF INVESTIGATIVE JOURNALISM (organização sem fins lucrativos criada por jornalistas do Reino Unido) e Alice Ross (jornalista, integrante do Bureau of Investigative Journalism) (queixa n. ${ }^{\circ}$ 62322/14); AMNesty International Limited, Bytes for All, The NATIONAL CounCIL FOR CIVIL LIBERTIES, UMA ENTIDADE PRIVADA COM FOCO NO DIREITO À PRIVACIDADE A NÍVEL INTERNACIONAL COM SEDE EM LONDRES (NÃO NOMEADA), THE AMERICAN CIVIL Liberties Union, The Canadian Civil Liberties Association, The Egyptian Initiative for Personal Rights, Társaság a Szabadságjogokért, An Chomhairle um Chearta Daonna e The legal Resources Centre (todas entidades ou organizações de direitos humanos e/ou de direito(s) à privacidade) (queixa n. ${ }^{\circ}$ n. ${ }^{\circ}$ 24960/15).

As queixas foram propostas logo após as revelações efetuadas por Edward Snowden, que em 2013 e nos anos seguintes divulgou documentos e informações confidenciais sobre os programas de vigilância eletrônica globais operados pelos serviços de inteligência dos Estados Unidos da América e do Reino Unido. Os requerentes alegaram acreditar que, em razão da natureza das atividades por eles exercidas (relacionadas ao jornalismo, à defesa do direito de liberdade de expressão e à defesa dos direitos humanos), haviam sido alvo de interceptação de comunicações pelos serviços de inteligência governo do Reino Unido, através (1) da interceptação direta pelos programas e sistemas de vigilância eletrônica do governo; (2) da obtenção, pelo governo do Reino Unido, de dados angariados pelo serviço de inteligência de governos estrangeiros, como os Estados Unidos; e (3) da obtenção, pelas autoridades do Reino Unido, de dados concedidos por serviços de comunicação.

Os requerentes questionaram a legalidade das diferentes estratégias dos serviços de inteligência do Reino Unido para interceptar e obter informações em massa e de modo oculto sobre os seus cidadãos e sobre estrangeiros mediante diferentes canais de comuni- 
cação, principalmente através do monitoramento do tráfego da Internet. Uma das estratégias empregadas pelo Government Communications Headquarters (GCHQ) do Reino Unido é a utilização do programa informático TEMPORA, que, entre outras funções, permite a interceptação em massa e gravação tradicional de comunicações telefônicas e a interceptação, coleta e análise do imenso volume de tráfego de dados que circulam pelos conglomerados de cabos de fibra óptica transoceânicos e continentais que estruturam a Internet e a criação de um índice, ou banco de dados, das informações obtidas.

\section{A. Alegações das partes}

\section{a) Requerentes}

No que tange à discussão aqui proposta, os requerentes alegaram violação ao artigo $8 .^{\circ}$ da Convenção Europeia dos Direitos do Homem ${ }^{11}$ - o qual versa sobre o direito ao respeito pela vida privada e familiar - pela lei britânica que regulava os poderes e medidas de interceptação à época (Regulation of Investigatory Powers Act 2000 - RIPA, atualmente revogada pelo Investigatory Powers Act 2016). Foi questionada a compatibilidade entre a Convenção e o regime de interceptação em massa de comunicações, previsto na seção 8(4) da Regulation of Investigatory Powers ${ }^{12}$.

11 Artigo 8. - Direito ao respeito pela vida privada e familiar "1. Qualquer pessoa tem direito ao respeito da sua vida privada e familiar, do seu domicílio e da sua correspondência". "2. Não pode haver ingerência da autoridade pública no exercício deste direito senão quando esta ingerência estiver prevista na lei e constituir uma providência que, numa sociedade democrática, seja necessária para a segurança nacional, para a segurança pública, para o bem-estar económico do país, a defesa da ordem e a prevenção das infracções penais, a protecção da saúde ou da moral, ou a protecção dos direitos e das liberdades de terceiros".

12 Section 8: "Contents of warrants. (1) An interception warrant must name or describe either- (a) one person as the interception subject; or (b) a single set of premises as the premises in relation to which the interception to which the warrant relates is to take place. (2) The provisions of an interception warrant describing communications the interception of which is authorised or required by the warrant must comprise one or more schedules setting out the addresses, numbers, apparatus or other factors, or combination of factors, that are to be used for identifying the communications that may be or are to be intercepted. (3) Any factor or combination of factors set out in accordance with subsection (2) must be one that identifies communications which are likely to be or to include- (a) communications from, or intended for, the person named or described in the warrant in accordance with subsection (1); or (b) communications originating on, or intended for transmission to, the premises so named or described. (4) Subsections (1) and (2) shall not apply to an interception warrant if- (a) the description of communications to which the warrant relates confines the conduct authorised or required by the warrant to conduct falling within subsection (5); and (b) at the time of the issue of the warrant, a certificate applicable to the warrant has been issued by the Secretary of State certifying- (i) the descriptions of intercepted material the examination of which he considers necessary; and (ii) that he considers the examination of material of those descriptions necessary as mentioned in section 5(3)(a), (b) or (c). (5) Conduct falls within this subsection if it consists in- (a)the interception of external communications in the course of their transmission by means of a telecommunication system; and (b)any conduct authorised in relation to any such interception by section 5(6). (6) A certificate for the purposes of subsection (4) shall not be issued except under the hand of the Secretary of State". 
Os requerentes reconheceram que a interceptação em massa possui previsão legal no direito interno britânico, porém questionaram a qualidade da lei, defendendo que a sua complexidade a tornava inacessível ao público, com disposições "abaixo da linha d'água" (below the waterline) e carente de diretrizes legais claras e garantias suficientes contra abusos. Em específico, foi alegado que a seção 8(4) da Regulation of Investigatory Powers Act não observava os seis requisitos identificados pelo Tribunal Europeu dos Direitos do Homem no julgamento do caso WEBER AND SARAVIA V. GERMANY (n. ${ }^{\circ}$ 54934/oo) - no qual fora questionada a compatibilidade do sistema alemão de interceptação de comunicações telefônicas com a Convenção Europeia dos Direitos do Homem, em razão de uma alteração legislativa na Alemanha que ampliou os poderes de interceptação de comunicações do serviço de inteligência alemão $0^{13}$-, a saber: (1) os casos de admissibilidade da interceptação de comunicações, em especial a natureza dos crimes que admitem este método de investigação; (2) a definição da categoria de pessoas que podem ter suas comunicações interceptadas; (3) o limite de duração da medida; (4) os procedimentos a serem observados no momento da análise, uso e preservação dos dados obtidos; (5) as precauções a serem tomadas na partilha dos dados com outras partes; e (6) as circunstâncias em que pode ou deve ser realizada a eliminação das gravações e/ou a destruição dos suportes físicos em que os dados foram guardados.

Em suma, os requerentes alegaram que (1) os crimes que permitiam o recurso à interceptação de comunicações não estavam suficientemente delimitados na lei em razão da evasividade do texto legal, característica que poderia abrir margem a arbitrariedades; (2) qualquer pessoa estava potencialmente sujeita a ter suas comunicações interceptadas, diante da indefinição legal quanto à distinção entre comunicações internas e externas e o seu âmbito de aplicação; (3) havia indefinição dos limites temporais da vigilância, a qual poderia perdurar ad infinitum; (4) os procedimentos de análise, seleção e preservação do material interceptado eram carentes de garantias adequadas; (5) em relação à comunicação de material interceptado, a garantia de que a divulgação se limitasse ao "mínimo necessário

13 Em suma, no caso Weber and Saravia v. Germany os requerentes alegaram violação da lei alemã sobre a limitação da privacidade das comunicações postais e telecomunicações (Gesetz zur Beschränkung des Brief-, Post- und Fernmeldegeheimnisses) aos artigos $8 .^{\circ}, 10 .^{\circ}$ e $13 .^{\circ}$ da Convenção Europeia dos Direitos do Homem, em virtude de uma alteração na referida norma, ocorrida em 1994, que ampliou os poderes de interceptação de comunicações do sistema de inteligência alemão ao criar a possibilidade de "monitoramento estratégico de telecomunicações", o qual consiste na coleta de informação através da interceptação de comunicações a fim de identificar e evitar graves ameaças à República Federal da Alemanha (como um ataque armado em seu território ou prática de crimes graves como delitos relacionados ao terrorismo). Os requerentes, uma jornalista alemã (Weber) e um cidadão uruguaio (Saravia), alegaram que a legislação alemã e a técnica investigativa de monitoramento estratégico de telecomunicações violavam seus direitos ao respeito pela vida privada e correspondência. O Tribunal Europeu dos Direitos do Homem não reconheceu nenhuma das violações alegadas e considerou que a legislação alemã era devidamente densificada e continha salvaguardas suficientes para proteger os direitos fundamentais dos investigados, uma legislação dotada do que o Tribunal classifica como quality of law. 
para os fins autorizados"14 era ineficaz; (6) inexistiam salvaguardas eficazes ou vinculativas referentes à detenção desproporcionada dos dados interceptados.

Foi também alegado pelos requerentes que os requisitos identificados no caso WEBER já estavam defasados no contexto atual, em virtude de o referido caso ter sido julgado em 2006, sendo que o desenvolvimento tecnológico posterior poderia significar a possibilidade de o Governo criar perfis detalhados e intrusivos de aspectos íntimos de vidas privadas a partir da análise de padrões de comunicação em uma interceptação em massa. Por conseguinte, os requerentes identificaram três novos requisitos que consideraram necessários para garantir a conformidade do quadro jurídico de vigilância com a Convenção Europeia dos Direitos do Homem: (1) exigência de provas de uma suspeita razoável em relação às pessoas alvo da interceptação; (2) autorização judicial prévia; e a (3) subsequente notificação da vigilância. Estes requisitos não foram estabelecidos no caso WEBER em virtude de o ordenamento jurídico interno alemão à época já os exigir no momento da aplicação do método oculto de investigação (escutas telefônicas, naquele caso), ao contrário da legislação britânica.

Por fim, também foi alegada a desproporcionalidade da seção 8(4) da Regulation of Investigatory Powers Act, por entenderem que os serviços de inteligência estavam coletando sistematicamente, em grande escala, não somente o conteúdo das comunicações em si mas também dados secundários de questionável necessidade para fins investigativos - como o histórico de navegação na Internet do indivíduo e a localização física do sistema vigiado -, retendo-os para a criação de um índice a fim de viabilizar pesquisas e usos futuros.

\section{b) Governo do Reino Unido}

O Governo do Reino Unido, por sua vez, alegou que as informações e a intelligence obtidas sob o abrigo da seção 8(4) da Regulation of Investigatory Powers Act eram essenciais para a proteção do Reino Unido contra ameaças à segurança nacional, particularmente, porém não de modo exclusivo, a ameaça do terrorismo. Como argumento, apontou a sofisticação dos terroristas e criminosos e a assimilação das novidades tecnológicas às suas práticas criminosas, especialmente a utilização de medidas antiforenses como modo de impedir a detecção das suas atividades (através da criptografia ou então de programas e sistemas informáticos de comunicação personalizados). A imposição de novas garantias, reivindicadas pelos requerentes, prejudicaria a capacidade do Estado em garantir a segurança nacional e de combater crimes de especial gravidade, especialmente em uma era em que os avanços nas tecnologias de comunicação aumentaram a ameaça de terrorismo praticado através da

14 Seção 15, n. ${ }^{\circ}$, in fine, da Regulation of Investigatory Powers Act. 
Internet. O requerido defendeu que, em observância à Convenção Europeia dos Direitos do Homem, cabia aos Estados avaliar as medidas necessárias para proteger a sociedade de tais ameaças, salientando que as interceptações em massa (inclusive aquelas promovidas nos cabos de fibra óptica que estruturam a Internet) são fundamentais para a descoberta de ameaças e dos seus possíveis responsáveis.

Por fim, o Governo entendeu que as interceptações encontravam previsão legal na Regulation of Investigatory Powers Act e que atendiam os requisitos oriundos do caso WEBER, pois havia previsão dos casos que admitiam o recurso à interceptação, das pessoas que poderiam ser alvo da medida ${ }^{15}$; disposições sobre os limites da medida ${ }^{16}$; regulamentação sobre o acesso e análise das informações (nenhum dado poderia ser lido, visto ou escutado por uma pessoa sem a autorização prévia do Secretário de Estado para a análise); disposições sobre a eliminação dos dados e destruição dos suportes físicos em que as informações estivessem preservadas ${ }^{17}$; e regulamentação sobre a divulgação e comunicação dos dados obtidos a outros Estados e serviços de inteligência ${ }^{18}$.

\section{B. Ratio decidendi}

A Corte começou por ressaltar que qualquer interferência aos direitos contidos no artigo 8..$^{\circ}$ da Convenção Europeia dos Direitos do Homem somente pode ser justificada, ao abrigo do $\S 2 .^{\circ}$ do artigo $8 .^{\circ}$ da Convenção, caso haja previsão legal e constitua uma providência necessária, em uma sociedade democrática, para alcançar os fins legítimos contidos no $§ 2 .^{\circ}$ do referido artigo (a segurança nacional, a segurança pública, o bem-estar económico do país, a defesa da ordem e a prevenção das infrações penais, a proteção da saúde ou da moral ou a proteção dos direitos e das liberdades de terceiros). Por "previsão legal", o Tribunal tem

15 De acordo com o Governo, os mandados previstos na seção 8(4) da Regulation of Investigatory Powers Act eram voltados à interceptação de comunicações externas, embora em determinados casos, relacionados ao mandado e sempre que necessário para interceptar comunicações externas, a interceptação de comunicações internas também fosse permitida.

16 O Governo defendeu que os parágrafos 6.22 a 6.24 do Interception of Communications Code, conjugados com as seções 8 e 9 da Regulation of Investigatory Powers Act, eram suficientes para suprir as disposições sobre os limites temporais das interceptações.

17 Foi defendido que tanto a Regulation of Investigatory Powers Act quanto o Interception of Communications Code possuíam disposições sobre a matéria.

18 O requerido defendeu que a seção $15(2)$ da Regulation of Investigatory Powers Act previa as precauções a serem tomadas referente à comunicação dos dados a outras partes, salientando que somente o que era considerado "necessário" para a finalidade autorizada poderia ser divulgado. Os parágrafos 7.4 e 7.5 do Interception of Communications Code, no entendimento do Governo, eram suficientes na regulamentação da comunicação dos dados obtidos a outros Estados, os quais estabelecem a necessidade de adoção pelos serviços de inteligência de medidas razoáveis para garantir que as autoridades do Estado estrangeiro tenham ou mantenham os procedimentos necessários para preservar o material interceptado, bem como garantir a sua divulgação, cópia, distribuição e retenção apenas na extensão mínima necessária. 
entendido ${ }^{19}$ ser necessária não somente uma base legal específica que preveja a restrição de um direito, mas também a clareza da lei, devendo ser acessível a todos os cidadãos e previsível quanto aos seus efeitos.

Em linhas gerais, o Tribunal considera que a previsão legal, ou a previsibilidade da lei - especialmente em casos de vigilância secreta e meios ocultos de investigação -, não diz respeito à possibilidade de o indivíduo a ser vigiado poder antecipar a vigilância e adaptar a sua conduta da maneira que julgar mais adequada, mas sim à necessidade de minucioso e claro detalhamento das regras referentes à medida, de modo a proteger o indivíduo do exercício arbitrário de medidas restritivas de direitos pelas autoridades responsáveis pela investigação.

Os constantes desenvolvimentos tecnológicos - os quais permitem a criação de novas ferramentas e técnicas de investigação a todo o instante - dão uma nova importância à referida exigência no contexto atual social.

Nos casos que envolvem interceptação de comunicações em investigações criminais, o Tribunal vem efetuando a análise da conformidade da lei interna com a Convenção a partir dos seis requisitos mínimos ${ }^{20}$ estabelecidos no caso WEBER AND SARAVIA V. GERMANY, previamente mencionados. Estes requisitos devem também ser observados nos casos em que a interceptação tiver como uma das finalidades a segurança nacional.

No que concerne à característica de a restrição aos direitos fundamentais constituir "uma providência necessária, em uma sociedade democrática", atentou-se ao fato de os Estados possuírem uma margem de apreciação para definir os meios e ferramentas que julgam aptos para assegurar a proteção da segurança nacional, margem esta que deve ser mais estreita caso haja a preferência à adoção do recurso de interceptação de comunicações. Esta margem está sujeita à supervisão dos tribunais europeus, devendo as autoridades estatais, ao efetuarem juízo sobre os meios de investigação a serem adotados, utilizarem como critérios em sua ponderação os princípios, os seis requisitos mínimos e as garantias estabelecidos pelo Tribunal Europeu de Direitos do Homem, além das disposições da legislação interna, de modo a impedir o abuso de poder e atentados à democracia travestidos na justificativa de salvaguarda da segurança nacional. Destarte, devem os Estados optar por

19 Quanto ao assunto, ver, entre outros, Roman Zakharov v. Russia (n. ${ }^{\circ} 47143 / 06$, julgado em 01 de dezembro de 2015); Weber and Saravia v. Germany (n. ${ }^{\circ}$ 54934/oo, julgado em 29 de junho de 2006); Rotaru $v$. Romania (n. ${ }^{\circ} 28341 / 95$, julgado em 04 de maio de 200o), todos julgados pelo Tribunal Europeu dos Direitos do Homem.

20 Relembramos: (1) definição de um catálogo de crimes que admitem o recurso à interceptação; (2) definição das pessoas que podem ter suas comunicações interceptadas; (3) limites e duração da interceptação; (4) os procedimentos que devem ser observados no tratamento dos dados obtidos (análise, uso e preservação das informações); (5) precauções a serem tomadas na comunicação dos dados a outras partes; (6) circunstâncias em que o material interceptado pode ou deve ser apagado ou destruído. 
métodos investigativos menos gravosos e somente recorrer aos mais intrusivos e restritivos quando aqueles forem insuficientes e estes revelarem-se indispensáveis.

Somente nos casos em que a legislação segue essas diretrizes é que o Tribunal Europeu dos Direitos do Homem reconhece que há qualidade de lei (quality of law): uma lei acessível, clara, previsível e dotada de garantias que legitimam a restrição de direitos fundamentais. Foi exatamente esta qualidade que os requerentes questionaram, a quality of law da seção 8(4) da Regulation of Investigatory Powers Act, em particular a sua acessibilidade e previsibilidade. A Corte cingiu-se à análise - no que tange à discussão proposta neste estudo -, da qualidade da referida lei britânica; da sua acessibilidade; da sua previsibilidade e da sua necessidade, tendo como base os seis requisitos mínimos previamente mencionados.

\section{a) Análise da acessibilidade, previsibilidade e necessidade da Regulation}

\section{of Investigatory Powers Act}

Seguindo o seu entendimento originado e reafirmado em casos pretéritos ${ }^{21}$, a Corte observou que os Estados não precisam tornar público todos os detalhes de um regime de vigilância secreta - as particularidades "abaixo da linha d'água" (below the waterline) -, pois tratam-se de características inerentes à atividade secreta. Basta que tais informações estejam disponíveis de modo suficiente em domínio público. São as disposições "acima da linha d'água" (above the waterline) que devem ser dotadas de previsibilidade, tendo como referência os seis requisitos mínimos estabelecidos no caso WEBER e fatores adicionais relacionados às medidas de vigilância secreta identificados no caso ZAKHAROV V. RUSSIA (n. ${ }^{\circ} 47143 / 06$ ) - em que o requerente alegou que a legislação russa viabilizava a instalação de equipamentos que permitiam a interceptação de comunicações telefônicas pelo serviço de inteligência russo sem prévia autorização judicial, violando o direito à privacidade de suas comunicações telefônicas (artigo 8..$^{\circ}$ da Convenção Europeia dos Direitos do Homem) -, a saber: a supervisão da medida, os mecanismos de notificação da interceptação e os instrumentos legais internos que possibilitem o questionamento da legalidade da vigilância.

Quanto ao primeiro requisito mínimo, considerou-se que a condição de previsibilidade não obriga os Estados a nomearem de forma exaustiva os crimes específicos aos quais o recurso à interceptação de comunicações pode ser aplicado, desde que presentes informações suficientes sobre a natureza das infrações em questão. A Corte já se posicionou, inclusive, contra a excessiva rigidez na redação do catálogo de crimes que admitem o uso

21 Ver, em especial, Szabó and Vissy $v$. Hungary (n. ${ }^{0}$ 37138/14, julgado em 12 de janeiro de 2016); Roman Zakharov $v$. Russia (n. ${ }^{\circ}$ 47143/06, julgado em 01 de dezembro de 2015); e Kennedy $v$. The United Kingdom (n. ${ }^{\circ}$ 26839/05, julgado em 18 de maio de 2010), todos julgados pelo Tribunal Europeu dos Direitos do Homem. 
de determinadas medidas de investigação ${ }^{22}$, de modo a possibilitar que a legislação acompanhe as mudanças tecnológicas e sociais. No presente caso, restou assentado que as ameaças à segurança nacional são imprevisíveis e podem se apresentar de diferentes modos, o que dificulta a sua definição prévia.

Os termos "segurança nacional" (national security) e "crime grave" (serious crime) contidos na legislação britânica foram considerados suficientemente claros, garantindo aos cidadãos indicações adequadas das circunstâncias em que as interceptações podem ser efetuadas.

Quanto ao termo national security, o Tribunal recordou que no caso KENNEDY V. THE UNITED KINGDOM (n. ${ }^{\circ}$ 26839/05) - em que, em suma, foi alegada violação da lei britânica à Convenção Europeia dos Direitos do Homem em virtude de suspeita de que as comunicações telefônicas e eletrônicas (e-mail) do requerente estavam sendo interceptadas pelo serviço de inteligência britânico devido ao seu pretérito envolvimento político em campanhas contra erros e abusos do sistema de justiça do Reino Unido - o Comissário para a Interceptação de Comunicações (Interception of Communications Commissioner) adotou, à época, a seguinte definição para o termo: "[atividades] que ameacem a segurança ou bem-estar do Estado e que visem enfraquecer ou derrocar a democracia parlamentar por meios políticos, industriais ou violentos"23.

Já o termo serious crime estava previsto, de modo compreensível, na seção $81(2)$ (b) da Regulation of Investigatory Powers Act (a qual faz remissão aos n. ${ }^{\circ}$ (3)(a) e (b) da seção 81): crimes em que a pena máxima prevista seja de três ou mais anos; ou então crimes que envolvam o uso de violência, que possam resultar em ganhos financeiros substanciais ou que sejam cometidos por um elevado número de agentes em desígnio comum²4.

Quanto ao segundo requisito, relacionado às pessoas suscetíveis a terem as suas comunicações interceptadas, restou reconhecido que os cabos de fibra óptica interceptados não eram escolhidos de forma aleatória, dava-se preferência aos canais de comunicações externos que tinham mais probabilidade de conduzir informações de interesse dos serviços de

22 Sobre o assunto, recomendamos, entre outros, a consulta aos casos Szabó and Vissy $v$. Hungary (n. ${ }^{\circ}$ 37138/14, julgado em 12 de janeiro de 2016) e Kokkinakis $v$. Greece (n. ${ }^{\circ}$ 14307/88, julgado em 25 de maio de 1993), ambos julgados pelo Tribunal Europeu dos Direitos do Homem.

23 Tradução nossa. No original: "[activities] which threaten the safety or well-being of the State, and which are intended to undermine or overthrow Parliamentary democracy by political, industrial or violent means".

24 Section 81. General interpretation. “(...) (2)In this Act- (...) (b) references to serious crime are references to crime that satisfies the test in subsection (3)(a) or (b). (3)Those tests are- (a) that the offence or one of the offences that is or would be constituted by the conduct is an offence for which a person who has attained the age of twentyone and has no previous convictions could reasonably be expected to be sentenced to imprisonment for a term of three years or more; (b) that the conduct involves the use of violence, results in substantial financial gain or is conduct by a large number of persons in pursuit of a common purpose". 
inteligência. Característica que, na opinião dos julgadores, não significa que os serviços de inteligência interceptavam a comunicação de todas as pessoas.

Contudo, as salvaguardas que regem a eleição dos canais de comunicação a serem interceptados e a seleção do material obtido foram consideradas precárias, não sendo suficientemente robustas para fornecer garantias adequadas contra abusos. Demonstrou-se uma nítida preocupação quanto à ausência de supervisão independente dos identificadores e dos critérios de busca utilizados na filtragem das comunicações interceptadas. A possibilidade de irrestrita busca e exame de "dados de comunicação acessórios" 25 (informações como a localização virtual ou física do equipamento interceptado - através do IP do equipamento ou de informações obtidas pelo uso de GPS, por exemplo -, a identificação do remetente e do destinatário de mensagens e dados do usuário sobre navegação na Internet) foi criticada pela Corte, que não restou convencida de que a colheita de tais dados era menos intrusiva que a obtenção do efetivo conteúdo da comunicação interceptada. Isso porque o conteúdo de uma comunicação eletrônica pode ser criptografada e, caso seja desencriptada, pode não revelar dados de interesse aos serviços de inteligência. Já os dados de comunicação acessórios, por outro lado, têm o potencial de revelar dados sensíveis dos participantes da comunicação. Nestes termos, reconheceu-se que as autoridades britânicas não efetuaram um justo equilíbrio entre os interesses públicos e os direitos individuais em conflito.

Os limites temporais da interceptação foram considerados adequados, com destaque à seção 9 da Regulation of Investigatory Powers Act, a qual previa limitações bem definidas (seis meses para a investigação de crimes que atentem à segurança nacional ou econômica; e três meses para a prevenção de crimes graves), garantias suficientes para impedir o abuso da medida.

Foram também julgados adequados os procedimentos e precauções que deveriam ser observados no tratamento dos dados obtidos (análise, uso e preservação dos conteúdos angariados). Os profissionais responsáveis pela análise das informações - especificamente autorizados e devidamente treinados para esta finalidade, conforme o parágrafo 7.15 do Interception of Communications Code - somente procediam ao exame do conteúdo selecionado pelo índice automaticamente criado pelos indicadores. Restava ab initio, portanto, afastada a análise dos materiais fora do índice, ou banco de dados, até mesmo porque estes eram descartados automaticamente. Ainda, os analistas somente estavam autorizados a examinar o conteúdo mediante a elaboração de um relatório prévio que elencasse os motivos legitimadores para tal exame, devendo demonstrar se a informação poderia ser obtida por outros meios de prova menos intrusivos.

25 Tradução livre de "related communications data" (§ $355 .^{\circ}$ da decisão). 
As garantias quanto às precauções a serem tomadas na comunicação dos dados a outras partes também foram consideradas adequadas. As disposições contidas na seção 15 da Regulation of Investigatory Powers Act e no capítulo 7. ${ }^{\circ}$ do Interception of Communications Code foram consideradas suficientemente eficazes para impedir abusos. Os referidos diplomas legais estabeleciam, em suma, que enquanto preservados, o acesso aos materiais ou dados deve ser limitado ao mínimo necessário para os "fins autorizados" ${ }^{26}$, estando sujeito a determinadas regras: limitação da partilha às partes às quais as informações foram divulgadas ou disponibilizadas; limitação até à extensão em que os dados foram divulgados ou disponibilizados; limitação à extensão da cópia do material ou dado; limitação ao número de cópias efetuadas. Nos casos em que o material interceptado for compartilhado com países ou territórios fora do Reino Unido, os serviços de inteligência britânicos devem assegurar que as autoridades às quais o conteúdo foi partilhado possuam (e observem) procedimentos estabelecidos para salvaguardar o material interceptado, garantindo que seja feita cópia, distribuição e retenção apenas na extensão mínima necessária, não podendo o material ser divulgado novamente para terceiros sem a explícita autorização dos serviços de inteligência britânicos, sendo necessária a devida destruição das informações após o uso para o qual foram colhidas.

As disposições acerca da eliminação e da destruição dos dados contidas na Regulation of Investigatory Powers Act e complementadas pelo Interception of Communications Code também foram consideradas suficientemente claras. As cópias do material obtido deveriam ser destruídas assim que não fossem mais necessárias para os fins previstos na seção 5(3) da Regulation of Investigatory Powers Act ${ }^{27}$; o conteúdo deveria ser mantido por até dois anos (e apagado por um processo de eliminação automático após o término do segundo ano); e deveria ser realizada uma avaliação, em intervalos apropriados, para confirmar se a retenção do conteúdo mantinha-se justificada.

No que toca à proporcionalidade das interceptações em massa, embora este meio de investigação possa provocar graves restrições aos direitos individuais ele também pode ser

26 De acordo com a seção 15 da Regulation of Investigatory Powers Act e parágrafo 7.2 do Interception of Communications Code, informações ou dados são considerados necessários para "fins autorizados" se continuarem a ser, ou for provável que se tornem, necessários ("if it continues to be, or is likely to become") para os fins mencionados na seção 5 (3) da Regulation of Investigatory Powers Act (interesses de segurança nacional; prevenção ou detecção de crimes graves; salvaguarda do bem-estar econômico do Reino Unido; cooperação internacional em casos de criminalidade grave); facilitar a realização das funções de interceptação promovidas pelo Secretário de Estado; facilitar o desempenho das funções do Comissário para a Interceptação de Comunicações ou do Tribunal de Poderes Investigatórios (IPT); para garantir ao órgão acusador as informações necessárias para conduzir a ação penal em observância ao devido processo legal; ou para o desempenho de funções impostas a qualquer pessoa sob a legislação de registros públicos ( $3655^{\circ}$ da decisão).

27 Em suma, interesses de segurança nacional; prevenção ou detecção de crimes graves; salvaguarda do bem-estar econômico do Reino Unido; cooperação internacional em casos de criminalidade grave. 
considerado uma estratégia valiosa para atingir os objetivos legítimos perseguidos, particularmente em virtude do atual nível de ameaça do terrorismo global e da criminalidade grave. A Corte reconheceu que a medida é proporcional com base nos relatórios do Independent Reviewer of Terrorism Legislation - o qual apontou o perigo apresentado por ferramentas informáticas sofisticadas que impedem a detecção de atividades por meios tradicionais de investigação e alertou a imprevisibilidade da rota que uma comunicação utiliza devido à natureza global da Internet - e da Comissão de Veneza (de março de 2015) - que reconheceu o intrínseco valor da interceptação em massa para operações de segurança por permitirem que os serviços de inteligência e de segurança adotem uma abordagem proativa na investigação de ameaças até então desconhecidas. ${ }^{28}$

Em relação à revisão, supervisão e notificação da vigilância, considerou-se que estas podem ocorrer em três momentos distintos: na ocasião de sua requisição, durante a sua implementação e após o seu término. Afastou-se qualquer possibilidade de questionamento ou supervisão nos dois primeiros momentos, para salvaguardar o sigilo da investigação e assegurar sua eficácia. Assim, a interceptação somente poderia ser questionada após o seu término, preferencialmente perante uma autoridade judicial, nos moldes da lei interna (como ocorre no Reino Unido com o Investigatory Powers Tribunal).

Estas considerações levaram o Tribunal a concluir que no caso BIG BROTHER WATCH as interceptações em massa foram realizadas dentro da margem de apreciação conferida aos Estados. Embora tenha reconhecido haver regulamentação sólida para esta modalidade de interceptação, duas áreas principais causaram preocupação: (1) a ausência de supervisão de todo o processo de seleção, incluindo a escolha dos cabos ou canais de comunicação a serem interceptados, os indicadores e critérios de busca para a filtragem das comunicações interceptadas e a seleção de material para exame por um analista; e (2) a ausência de salvaguardas aplicáveis à seleção de dados de comunicações acessórios para análise.

Por todas estas razões, em especial às duas deficiências destacadas anteriormente, o Tribunal Europeu dos Direitos do Homem considerou que o regime da seção 8(4) da Regulation of Investigatory Powers Act não atendia ao requisito da quality of law, sendo incapaz de manter a sua interferência no que é "necessário, em uma sociedade democrática", confirmando violação do artigo $8 .^{\circ}$ da Convenção Europeia dos Direitos do Homem.

\section{b) Acréscimo de novos requisitos mínimos}

Embora não tenha negado o impacto das tecnologias modernas na intrusão das interceptações, a Corte Europeia dos Direitos do Homem não considerou serem as interceptações em 
massa mais intrusivas na vida privada de um indivíduo do que a interceptação tradicional (direcionada), por entender que desta última pode resultar mais material sobre a vida do indivíduo e suas comunicações.

O Tribunal reconheceu que os requisitos mínimos adicionais propostos pelos requerentes podem constituir garantias importantes em determinados casos, porém não considerou apropriado adicioná-los aos seis já existentes. No que tange à exigência de provas de uma suspeita razoável em relação às pessoas alvo da interceptação e a sua subsequente notificação, o acréscimo de tais requisitos seria inconsistente quanto ao respeito à margem de apreciação dos Estados em definir os meios e ferramentas que julgam aptos para assegurar a proteção da segurança nacional. A interceptação em massa, por definição, não possui alvos pré-definidos e dessa forma ambos requisitos tornar-se-iam obstáculos à aplicação da medida, já que pressupõem a existência de alvos de interceptação claramente definidos.

Quanto à exigência de autorização judicial prévia, o Tribunal não encontrou nenhuma incompatibilidade com a interceptação de comunicações - reconhecendo, inclusive, se tratar de uma "importante garantia contra arbitrariedades" 29 -, porém julgou ser um requisito desnecessário. Isso porque em diferentes países europeus, como no Reino Unido, há a possibilidade de questionar a legalidade da interceptação posteriormente pela via judicial. A possibilidade de supervisão independente - por agentes especializados não envolvidos com a investigação, por exemplo - supriria a autorização judicial prévia, o que, no entendimento do Tribunal, constitui uma garantia contra abusos. A autorização judicial prévia não necessariamente impediria a "possibilidade de ação imprópria por um agente desonesto, negligente ou excessivamente zeloso"30, como observado no caso RoMAN ZAKHAROV. São mais importantes, na verdade, a atenção ao real funcionamento do sistema de interceptação, a observância ao sistema de pesos e contrapesos sobre o exercício do poder e a existência ou ausência de qualquer evidência de verdadeiro abuso (como a autorização de interceptações a esmo, de forma irregular ou sem a devida e apropriada consideração dos interesses e direitos em conflito).

\section{Análise crítica}

Narrados os principais fundamentos do julgamento, é perceptível que se trata de um julgamento paradigmático, podendo ser considerado, até certo ponto, uma vitória do direito fundamental à privacidade sob meios ocultos de investigação. Demonstra-se louvável o reconhecimento por parte do Tribunal Europeu dos Direitos do Homem de que as intercep-

29 Tradução nossa. No original: "important safeguard against arbitrariness" (§ 318. ${ }^{\circ}$ da decisão).

30 Tradução nossa. No original: "the possibility of improper action by a dishonest, negligent or over-zealous official" (§ $319 .^{\circ}$ da decisão). 
tações possuem um elevado potencial intrusivo, seja na sua modalidade em massa, seja na direcionada, principalmente em razão da possibilidade de obtenção de dados de comunicação acessórios.

$\mathrm{Na}$ atual era da sociedade da informação (digital), a interceptação não se restringe mais à lógica da interceptação tradicional. Hoje a pluralidade de sistemas informáticos e dispositivos eletrônicos e a sua adoção por grande parte da sociedade permitem que o Estado obtenha muitos mais dados quando aplica medidas de vigilância. As informações que podem ser obtidas são quase infindáveis, além dos elementos clássicos como a palavra falada e a palavra escrita, atualmente é possível obter uma vasta gama de informações sobre o indivíduo, algumas mais sensíveis que outras, como: documentos eletrônicos, palavras-passe, localização, monitoramento em tempo real do indivíduo e do conteúdo inserido ou digitado no sistema ou dispositivo. As informações disponíveis dependem, primeiramente, do dispositivo eletrônico ou do sistema informático interceptado e, em segundo lugar, da técnica ou da ferramenta utilizada na investigação.

A estrutura dos canais de comunicações - pense-se aqui sobretudo ao vasto fluxo informacional que percorre os cabos de fibra óptica que estruturam a Internet -, o desenvolvimento de novas tecnologias e sistemas informáticos e a proliferação e adesão massiva de dispositivos eletrônicos - os quais se tornaram, em muitos casos, ferramentas essenciais, ou umbilicais, para o desenvolvimento de inúmeras tarefas, das mais banais ate as mais intricadas - são fatores que devem ser sopesados atualmente no contexto das interceptações de comunicações.

Todos estes motivos levam-nos a discordar do Tribunal quanto à dispensabilidade da atualização dos requisitos mínimos, originados no caso WEBER, a serem observados na aplicação de uma medida de interceptação, bem como da prescindibilidade da criação de novas exigências. A realidade tecnológica e social à época em que o caso foi julgado (29 de junho de 2006) não guarda mais relação com a atual, o salto tecnológico dado desde então foi significativo. O escopo das (ferramentas utilizadas nas) interceptações naquela ocasião era patentemente mais restrito que aquele viabilizado pelas ferramentas de investigação atuais.

Independentemente da modalidade e da finalidade, a interceptação de comunicações é uma medida dotada de um inerente potencial intrusivo nos direitos fundamentais também dos indivíduos não relacionados à investigação, especialmente quando se trata de interceptação em massa, em que há uma ampla recolha de informações sem qualquer diferenciação entre os alvos, com a colheita de informações sobre pessoas não relacionadas a crimes graves ou ao terrorismo (podendo inclusive adentrar em esferas protegidas por sigilo profissional). Evidentemente, o terrorismo e outras modalidades de crimes graves são uma 
ameaça real no mundo atual, perigos que não podem, contudo, ser invocados oportunisticamente como se fossem um estandarte para a adoção de medidas altamente restritivas a direitos fundamentais, em especial para a averiguação de ameaças amplas como a segurança nacional ou o bem-estar econômico do Estado, sem estarem tais medidas submetidas a verdadeiras garantias contra abusos, como ressaltado no voto dissidente do Juiz Koskelo no julgamento do caso BIG BROTHER WATCH ${ }^{31}$.

Não concordamos com o entendimento do Tribunal, em especial, quanto à desnecessidade de uma autorização judicial prévia e de elementos que confirmem a suspeita da ameaça como requisitos extras aos seis já existentes. Em função do potencial lesivo a direitos fundamentais inerente a uma interceptação de comunicações e a possibilidade de abusos da medida, julgamos indispensável a exposição dos motivos que fundamentam o recurso à interceptação. O controle posterior, como ocorre no Reino Unido, é, ao nosso ver, uma importante garantia, porém insuficiente, per se, para a proteção de abusos durante a aplicação da medida. A má aplicação do recurso à interceptação ab initio pode invalidar por completo todo o esforço investigativo, tornando nulas as provas obtidas em desconformidade com as orientações constitucionais, com possíveis efeitos-à-distância ${ }^{32}$. $\mathrm{O}$ argumento do Tribunal de que a autorização judicial prévia não seria uma garantia suficiente não procede, porém não deve invalidar o acréscimo deste requisito, porquanto tratar-se-ia de uma salvaguarda adicional a ser observada na implementação de um recurso excepcionalmente gravoso.

Embora os Estados devam dispor de uma margem de apreciação na escolha dos meios aptos a promover as suas atividades investigativas, principalmente nos casos que atentam à segurança nacional, a probabilidade de abusos e a gravosa restrição a direitos fundamentais decorrentes do recurso à interceptação de comunicações impõem um estreitamento dessa margem e a designação de garantias sólidas.

A necessidade de garantias adicionais, ou no mínimo a atualização dos requisitos existentes, é evidente.

O Tribunal Europeu dos Direitos do Homem perdeu uma verdadeira chance de adaptar o seu entendimento à realidade atual e aos futuros desafios em matéria de interceptação de comunicações e vigilância em geral.

$31 \S \S 11 .^{\circ}$ a $15 .^{\circ}$ do voto dissidente do Juiz Koskelo.

32 "[A]s provas que atentam contra os direitos de liberdade arrostam com um efeito-à-distância que consiste em tornarem inaproveitáveis as provas secundárias a elas causalmente vinculadas" (MENDES, Paulo de Sousa - O efeito-à-distância das proibições de prova. In Revista do Ministério Público do RS. Porto Alegre. [ISSN]. N. ${ }^{\circ} 74$, 2013, p. 219). 
As problemáticas decorrentes do uso de métodos ocultos de investigação não são novas $^{33}$. Embora tenhamos tecido críticas ao Tribunal Europeu dos Direitos do Homem quanto à oportunidade perdida de atualizar o seu entendimento em matéria de interceptação de comunicações - e, de certa maneira, no tocante aos métodos ocultos de investigação - devemos reconhecer um certo grau de mérito do julgamento, pois fortaleceu a posição do Tribunal quanto aos requisitos mínimos a serem observados na previsão (e na aplicação) de métodos ocultos de investigação - principalmente aqueles novos oriundos do desenvolvimento tecnológico -, de modo a garantir ao máximo possível a proteção contra usos abusivos desta espécie de meio de obtenção de prova.

\section{O uso de softwares de espionagem como método oculto de obtenção de prova}

Analisaremos agora uma nova tecnologia de inestimável valia à investigação criminal, a qual tem sido paulatinamente implementada em diferentes países europeus, pese embora pouco debatida pela doutrina portuguesa ${ }^{34}$ : os softwares de espionagem.

Os softwares de espionagem ${ }^{35}$ são programas informáticos elaborados para fins de extração de dados contidos em um sistema informático ou aparelho eletrônico sem o conhecimento ou consentimento do seu utilizador ${ }^{36}$. Tratam-se de programas que podem ser insta-

33 Remetemos o leitor às obras citadas na nota 9 para o conhecimento aprofundado das problemáticas inerentes aos métodos ocultos de investigação criminal.

34 Com exceção de David Silva Ramalho (cf. RAMALHO, David Silva - Métodos Ocultos de Investigação Criminal em Ambiente Digital. Coimbra: Almedina, 2017); Duarte Alberto Rodrigues Nunes (cf. NUNES, Duarte Alberto Rodrigues - Os Meios de Obtenção de Prova Previstos na Lei do Cibercrime. Coimbra: Gestlegal, 2018); e Benjamim Silva Rodrigues (cf. RODRIGUES, Benjamim Silva - Da Prova Penal - Tomo II - Bruscamente... A(s) face(s) oculta(s) dos métodos ocultos de investigação criminal. Cascais: Rei dos Livros, 2010), a doutrina portuguesa parece ainda não ter percebido a complexidade e gravidade das problemáticas que gravitam em torno deste novo método de obtenção de prova. Em certos casos, como ocorre com os dois últimos autores citados, há ainda a confusão de softwares de espionagem com as buscas online, métodos de obtenção de prova distintos.

35 Preferimos adotar o termo software de espionagem para evitar a redução deste programas à determinadas modalidades de softwares espiões, como é o caso dos autores que utilizam o termo "cavalo de Tróia", o qual na verdade é apenas uma das espécies de software de espionagem identificação de uma modaldiade de software de espionagem. Também afastamos o termo malware (contração de malicious software) a fim de evitar a interpretação de que todo o software de espionagem é necessariamente mal intencionado ou ilegal.

36 Cf. MARSHALL, Angus - Digital Forensics - Digital Evidence in Criminal Investigation. Chichester: WileyBlackwell, 2008, p. 66; BOLDT, Martin - Privacy-Invasive Software - Exploring Effects and Countermeasure, 2007. 138 f. Monografia de Licenciatura (Licenciatura em Ciência e Tecnologia da Computação)-Department of Systems and Software Engineering da Blekinge Institute of Technology, Karlskrona, 2007. [Consultado em: 23 de abril de 2018]. Disponível em: https://www.diva-portal.org/smash/get/diva2:837092/FULLTEXTo1.pdf, p. 10; FILIOL, Eric. Computer viruses: from theory to application. Paris: Springer, 2005, p. 83. 
lados de múltiplas formas ${ }^{37}$ (via Internet ou através de um pen-drive, por exemplo), capazes de executar diferentes funções no dispositivo monitorado, as quais variam de acordo com a sua estrutura (modalidade) e finalidade. A implementação de um software de espionagem em um sistema informático ou dispositivo eletrônico permite a extração de uma vasta gama de dados, desde documentos, palavras-passe, localização física, até mesmo monitoramento audiovisual em tempo real e informações biométricas do usuário guardadas no sistema (como os dados guardados necessários para o reconhecimento facial para desbloqueio e uso de um smartphone, por exemplo). A depender da modalidade de softwares de espionagem instalado, é possível até mesmo efetuar alterações nas informações contidas no dispositivo investigado ${ }^{38}$. Trata-se de um método de investigação mais intrusivo e potencialmente mais eficaz que uma mera interceptação de comunicações.

Por se tratarem de programas instalados e executados de forma sub-reptícia, os softwares de espionagem apresentam um valor ímpar como ferramenta de investigação criminal: permitem a obtenção de múltiplas informações antes de sua eliminação ou ocultação por medidas antiforenses.

Perceptível, desde já, a gravidade que estes softwares representam a direitos fundamentais. Em razão da sua mais valia à investigação criminal, dos conflitos que o seu uso gera entre os interesses da Justiça e da sua patente restrição de direitos, diferentes países europeus vêm implementando com cautela e com a devida densificação normativa este novo método de obtenção de prova em seus ordenamentos jurídicos, de forma a viabilizar o uso deste novo meio de obtenção de prova da maneira menos intrusiva a direitos e liberdades fundamentais, garantindo, ao mesmo tempo, a proteção destes.

\section{A. Alguns exemplos do uso de software de espionagem na Europa}

Talvez o exemplo que melhor ilustre a problemática da assimilação de novas tecnologias para a criação de novos métodos de obtenção de prova seja o exemplo alemão ${ }^{39}$. O legislador alemão vem tentando regulamentar o uso de software de espionagem (conhecido como Bundestrojaner) desde 2006, quando a sua utilização foi viabilizada por uma alteração na Lei de Proteção da Constituição da Renânia do Norte-Vestfália para fins de proteção a ameaças

37 RAMALHO, David Silva - O uso de malware como meio de obtenção de prova em processo penal. Revista de Concorrência e Regulação. Lisboa. ISSN 1647-5801. A. IV, N. ${ }^{\circ}$ 16, 2013, pp. 205-207; CLOUGH, Jonathan - Principles of Cybercrime. Cambridge: Cambridge University Press, 2010, p. 32.

38 FILIOL, Eric. Op. cit., p. 83; CLOUGH, Jonathan. Op. cit., pp. 32 e 34.

39 Para mais informações sobre o software de espionagem para fins investigativos na Alemanha, cf. FORGÓ, Nikolaus; HAWELLEK, Christian; KNOKE, Friederike; STOKLAS, Jonathan - The Collection of Electronic Evidence in Germany: A Spotlight on Recent Legal Developments and Court Rulings. In: New Technology, Big Data and the Law. Singapore: Springer Nature, 2017, p. 251-279. 
à livre ordem democrática fundamental ou à continuada existência ou segurança da Federação. Contudo, em 27 de fevereiro de 2008 o Tribunal Constitucional alemão julgou ${ }^{40}$ a referida alteração legislativa inconstitucional, porquanto, em suma, violava direitos e princípios fundamentais, como o direito geral à personalidade, o princípio da segurança jurídica, o princípio da proporcionalidade e a falta de salvaguardas suficientes para assegurar a proteção da área central da vida privada. Neste mesmo julgamento, o Tribunal Constitucional criou um novo direito fundamental: a confidencialidade e integridade de sistemas informáticos, o qual tem como finalidade a proteção do interesse do usuário em garantir que os dados criados, processados e armazenados por um sistema informático acobertados pelo seu âmbito de proteção restem confidenciais. Naquela decisão, o Tribunal estabeleceu diretrizes constitucionalmente orientadas para uma futura regulamentação deste novo método de obtenção de prova na Alemanha.

Em 25 de dezembro de 2008 entrou em vigor na Alemanha a Bundeskriminalamtgesetz (BKAG), lei editada em observância às orientações do Tribunal Constitucional, prevendo o uso de softwares de espionagem para fins de prevenção e investigação em crimes relacionados ao terrorismo. Contudo, em 20 de abril de 2016, o Tribunal Constitucional julgou ${ }^{41}$ inconstitucionais as disposições contidas no § 20k da BKAG (artigo que regulamentava o uso de software de espionagem), por não se adequarem a uma série de requisitos relacionados ao princípio da proporcionalidade e à proteção de direitos fundamentais (semelhantes aos requisitos de WEBER do Tribunal Europeu dos Direitos do Homem, como os casos que admitem a aplicação da medida; extensão da medida a terceiros; exigência de salvaguardas capazes de proteger o núcleo da vida privada, entre outros), determinando a revisão da BKAG.

A revisão da BKAG foi realizada em $1 .^{\circ}$ de junho de 2017 e entrou em vigor em 25 de maio de 2018. Atualmente, o uso de software de espionagem está regulamentado no ordenamento jurídico alemão no $§ 49$ da BKAG, o qual prevê todas as especificidades sobre o uso deste método de investigação, como os crimes aos quais a medida é permitida (criminalidade grave e terrorismo); o seu alcance; a sua duração (limitado a um máximo de três meses, podendo ser prorrogado por igual prazo); os pressupostos de admissibilidade (requisição da autoridade competente e autorização judicial, devendo em ambos os casos haver a descrição da pessoa à qual a medida é direcionada e do sistema informático a ser vigiado); disposições sobre conservação e eliminação dos dados obtidos, entre outras particularidades. Não houve ainda pronúncia do Tribunal Constitucional sobre a conformidade constitucional

40 BVerfG, Urteil des Ersten Senats vom 27. Februar 2008 - 1 BvR 370/07 - Rn. (1-333).

41 BVerfG, Judgment of the First Senate of 20 April 2016 - 1 BvR 966/09 - paras. (1-360). 
destas novas regulamentações, contudo a simples comparação da atual versão da BKAG com a versão anterior evidencia progressos na densificação do dispositivo legal que regulamenta o Bundestrojaner.

A França prevê o uso de software de espionagem (denominado dispositif technique pelo legislador francês) para fins de investigação criminal nos artigos 706-102-1 a 706-102-9 do Code de Procédure Pénale ${ }^{42}$. Em linhas gerais, o recurso ao dispositif technique é restrito aos crimes de elevada gravidade, depende de requisição devidamente fundamentada pelo Parquet e de autorização judicial, a qual deve especificar o modo de funcionamento do software (detalhes sobre o sistema informático a ser monitorado, duração do monitoramento, modo de instalação, períodos em que pode ser ativado). O diploma processual penal francês também estabelece a obrigatoriedade de realização de relatório das operações e dispõe sobre a conservação e destruição do conteúdo obtido.

$\mathrm{Na}$ Espanha ${ }^{43}$, o uso de software de espionagem encontra previsão legal no $\mathrm{n}^{\circ} 1$ do artigo 588 septies $a$, suplementado pelos artigos 588 septies a ao 588 bis k, todos da Ley de Enjuiciamiento Criminal. Assim como ocorre no ordenamento jurídico francês, a legislação espanhola prevê os crimes que admitem este recurso, estabelecendo também a necessidade de requisição e decisão, devidamente fundamentadas, devendo a decisão que autoriza a medida especificar o seu modo de funcionamento (a modalidade de software de espionagem a ser empregada, o alcance do software espião, o modo como os dados serão obtidos e preservados, os agentes autorizados a implementá-lo, a sua duração, a sua documentação, a conservação dos dados angariados).

$\mathrm{Na}$ Itália ${ }^{44}$, o uso de software de espionagem para fins de investigação criminal encontra previsão legal desde o início de 2018. O captatore informatico, como é conhecido na Itália, está disposto no artigo 266, n. ${ }^{\circ} 2$ e artigos seguintes do Código de Processo Penal. O capta-

42 Para um estudo mais aprofundado do sistema de interceptação de comunicações francês e uma análise sobre o uso do dispositif technique no processo penal francês, cf. FÈVRE, Paul Le - Il regime della captazzione dei dati informatici nel diritto francese. In Parola alla Difesa. Pisa. ISSN 2531-680X. N. ${ }^{\circ} 1,2016$, p. 181-183; HUYGHE, François-Bernard - Les Écoutes Téléphoniques. Paris: Presses Universitaires de France, 2009; GUERRIER, Claudine - Révision du code de procédure pénale 2016: le nouveau régime des interceptions électroniques. [Consultado em: 02 de Outubro de 2018]. Disponível em: http://www.juriscom.net/wp-content/ uploads/2016/10/20161026penalcomm.pdf.

43 Para mais informações sobre o uso software de espionagem no ordenamento jurídico espanhol, cf. COLOMER, Juan-Luis Gómez - El processo penal español a comienzos del siglo XXI. Diagnóstico sobre sus principales problemas y propuesta de posibles soluciones, al hilo de la lucha contra la criminalidad organizada y la persecución de los delitos de corrupción. In InDret. Barcelona. ISSN 1698-739X. N. ${ }^{\circ}$ 1, 2017, p. 1-59; PRADIILLO, Juan Carlos Ortiz - La investigación del delito en la era digital: Los derechos fundamentales frente a las nuevas medidas tecnológicas de investigación - Estudios de Progreso - Fundación Alternativas. Madrid: Fundación Alternativas, 2013.

44 Para mais informações sobre o uso software de espionagem no ordenamento jurídico italiano, cf. FELICIONI, Paola - Lacquisizione da remoto di dati digitali nel procedimento penale: evoluzione giurisprudenziale e prospettive di riforma. Processo Penale e Giustizia. Torino. ISSN 2039-4527. N. ${ }^{\circ}$, 2016, p. 118-138; FILIPPI, 
tore informatico é um recurso direcionado a crimes graves (como criminalidade organizada, terrorismo, tráfico de estupefacientes, entre outros), que depende da requisição do Ministério Público (com demonstração de indícios de crime e suficientes justificativas para a imprescindibilidade da medida e a duração pretendida da medida) e de autorização judicial (a qual deve detalhar todo o funcionamento do captatore, em especial as funções a serem ativadas). A operação deve ser documentada (implementação, uso, dados obtidos, requisições autorizações da medida e eventuais prorrogações, conservação e eliminação de dados) e deve respeitar a inviolabilidade do domicílio do investigado, a menos que hajam indícios suficientes que levem a crer que as práticas ilícitas investigadas estejam a ocorrer naquele local (este requisito não é necessário para crimes relacionados ao terrorismo ou à criminalidade organizada, os quais permitem a restrição da privacidade do domicílio do investigado).

\section{B. O software de espionagem no ordenamento jurídico português: previsão legal?}

Como modo de adequar o ordenamento jurídico interno à legislação supranacional e aos tratados internacionais, bem como na tentativa de ultrapassar os desafios decorrentes da evolução tecnológica, sobretudo em ambiente digital, o legislador português editou a Lei n. ${ }^{0}$ 109/2009, de 15 de setembro. A "Lei do Cibercrime" pode ser classificada como um avanço no ordenamento jurídico português. Além de compatibilizar a realidade jurídica à realidade técnica, a lei prevê novos métodos de obtenção de prova que fazem uso das tecnologias de informação, como o acesso a dados informáticos; as buscas online; a apreensão de correio eletrônico; e o recurso às ações encobertas em ambiente digital.

O artigo 19 da Lei do Cibercrime, que trata das ações encobertas em ambiente digital, dispõe em seu n. ${ }^{\circ} 2$ que: "Sendo necessário o recurso a meios e dispositivos informáticos observam-se, naquilo que for aplicável, as regras previstas para a intercepção de comunicações"45, abrindo discussão $0^{46}$ sobre a consagração do uso de software de espionagem em Portugal.

Apesar de merecedora de louvor quanto as suas demais disposições, a Lei do Cibercrime padece de atecnia legislativa ao (aparentemente) tentar introduzir novas tecnologias digitais de espionagem, nomeadamente os softwares de espionagem, para fins de investigação criminal no direito português. Embora não seja o objetivo do presente estudo analisar a conformidade constitucional do dispositivo, não podemos deixar de registrar nosso descontentamento quanto ao n. ${ }^{\circ} 2$ do artigo $19 .^{\circ}$ da referida lei. A disposição é de dúbia

L. - Lispe-perqui-intercettazione "itinerante": le Sezioni Unite azzeccano la diagnosi, ma sbagliano la terapia. Parola alla Difesa. Pisa. ISSN 2531-680X. N. ${ }^{\circ}$ 1, 2016, p. 179-181; VELANI, Luigi Gino - Trojan horse, strumenti investigativi e diritti fondamentali: alla ricerca di un difficile equilibrio. Parola alla Difesa. Pisa. ISSN 2531-680X. N. ${ }^{\circ} 1,2016$, p. 173-179.

45 Destaques nossos.

46 RAMALHO, David Silva - Métodos Ocultos de... cit., p. 338 e ss. 
constitucionalidade, os métodos ocultos de investigação criminal, por serem métodos relativamente proibidos de prova, reclamam uma densificação legal robusta, como vimos anteriormente. A simples previsão legal com remissão ao regime da interceptação de comunicações quando houver necessidade de suplementação é exígua. Além de serem meios de obtenção de prova nitidamente distintos, aquele regime não contém disposições específicas ao funcionamento de um software de espionagem (como as funções que podem ser ativadas, o modo como deve ser realizada a obtenção das informações ou então a instalação e remoção do sistema informático ou dispositivo eletrônico investigado). O alarmante potencial lesivo a direitos fundamentais decorrente do uso de softwares de espionagem demanda clareza, densidade e precisão na regulamentação deste recurso, o que não ocorre na atual versão da Lei do Cibercrime.

De fato, restrições a direitos fundamentais somente podem operar mediante uma interpretação constitucionalmente orientada ${ }^{47}$, de modo que só há interpretação conforme à Constituição se a restrição for justificada e adequada diante da necessidade de proteção ou promoção de um interesse constitucional, na medida da necessidade em questão ${ }^{48}$. Imperiosa, portanto, a observância ao princípio da legalidade ${ }^{49} \mathrm{em}$ matéria de métodos de investigação criminal, principalmente quando se tratar de um método oculto. Como ensina Manuel Monteiro Guedes Valente, "A sociedade internético-personocêntrica (...) exige um melhor legislador, hermeneuta, um melhor exegeta e um melhor aplicador da norma dentro da materialidade constitucional democrática, garantista e humanista" ${ }^{50}$. Imperiosa a observância aos princípios e orientações constitucionais em matéria de produção probatória $^{51}$ - legalidade, reserva de Constituição, reserva de lei, reserva de código, segurança jurídica, determinabilidade, catálogo, excepcionalidade, entre outros - sobretudo em métodos ocultos de investigação, e ainda mais naqueles tão intrusivos quanto o uso de software de espionagem.

E aqui voltamo-nos à importância do julgamento do caso BIG BROTHER WATCH AND Others v. The United Kingdom pelo Tribunal Europeu dos Direitos do Homem. Mesmo que

47 MIRANDA, Jorge - Direitos Fundamentais. Coimbra: Almedina, 2017, p. 463.

48 ANDRADE, José Carlos Vieira de - Os Direitos Fundamentais na Constituição Portuguesa de 1976. 5. ${ }^{\mathrm{a}}$ ed. Coimbra: Almedina, 2012, p. 287.

49 CAIRES, João Gouveia de - O registo de som e imagem e as escutas ambientais. In Direito da Investigação Criminal e da Prova. Coimbra: Almedina, 2014, p. 275.

50 VALENTE, Manuel Monteiro Guedes - O Reforço dos Princípios Constitucionais na Obtenção de Prova no Mundo Digital. Corpus Delicti - Revista de Direito de Polícia Judiciária. Brasília. ISSN 2526-4265. V. 2, N. ${ }^{\circ} 3$, 2018, p. 23.

51 O autor faz uma acurada análise dos princípios a serem observados em matéria de métodos ocultos de obtenção de prova em VALENTE, Manuel Monteiro Guedes - O Reforço dos Princípios Constitucionais na Obtenção de Prova no Mundo Digital. Corpus Delicti - Revista de Direito de Polícia Judiciária. Brasília. ISSN 2526-4265. V. 2, N. ${ }^{\circ} 3,2018$, pp. $15-22$. 
os Estados tenham uma margem de apreciação na escolha dos meios aptos a promover as suas atividades investigativas, a assimilação e a aplicação de novas tecnologias à investigação criminal somente pode ser operada em estrita observância a uma regulamentação prévia dotada de qualidade, de modo a impedir restrições abusivas e desproporcionais a direitos fundamentais. É precisamente o que não ocorre na Lei do Cibercrime, legislação portuguesa que, ao contrário dos exemplos legislativos estrangeiros, não prescreve as particularidades inerentes aos "meios e dispositivos informáticos" dos quais versa. Não há, atualmente, base legal que autorize o uso de software de espionagem para fins de prevenção ou investigação em Portugal.

\section{Conclusões}

O avanço tecnológico iniciado nas últimas décadas do século passado reestruturou incontornavelmente a vida em sociedade. O desenvolvimento e a sofisticação de novos sistemas informáticos e aparelhos eletrônicos remodelou diferentes áreas basilares do convívio em sociedade, revolucionando e facilitando, por exemplo, as práticas econômicas e comunicacionais. Há cada vez mais adesão social às tecnologias de informação, devido à praticidade que conferem à execução de incontáveis atividades, desde as mais banais até as mais complexas.

Contudo, esta funcionalidade não se restringe a atividades lícitas. Há, também, cada vez mais assimilação de novas tecnologias de informação para a perpetração de práticas ilícitas, principalmente daquelas ferramentas capazes de ocultar a atividade criminosa e/ ou evadir tentativas de investigação, o que reclama dos Estados a necessidade de idealizarem métodos de investigação capazes de contornar tais obstáculos. Surgem então novos métodos de investigação - especialmente métodos ocultos de investigação, em razão da possibilidade de antecipação de qualquer tentativa de ocultação de dados, como os softwares de espionagem -, e a imprescindibilidade do aprimoramento daqueles já existentes, como os complexos programas de interceptação de comunicações em massa empregados pelos serviços de inteligência do Reino Unido.

No caso Big Brother Watch and Others v. The United Kingdom, o Tribunal Europeu dos Direitos do Homem reconheceu o valor e também a gravidade das interceptações de comunicações (em massa e direcionadas) como métodos de investigação. Embora possam obter dados valiosos para fins preventivos e investigativos, tratam-se de recursos com alta potencialidade de restrição de diferentes direitos fundamentais (no caso BIG BROTHER WATCH, especificamente, os direitos à privacidade, previstos no artigo $8 .^{\circ}$ da Convenção Europeia dos Direitos do Homem), por serem capazes de obter informações acessórias inci- 
dentais que dizem respeito à vida íntima do indivíduo vigiado e de outras pessoas que com ele se comuniquem. O Tribunal solidificou a sua jurisprudência ao ressaltar a importância de previsão legal para a viabilização de métodos de investigação restritivos de direitos como as interceptações, observando, contudo, a imprescindibilidade desta base legal ser dotada de suficiente qualidade, de modo a impedir arbitrariedades.

A referida decisão é paradigmática, pois reforça não somente o entendimento do Tribunal Europeu dos Direitos do Homem como também fortalece a doutrina portuguesa e europeia que com tanto esforço vem defendendo a necessidade de adequada densificação normativa dos métodos ocultos de investigação.

Os reflexos desta decisão em matéria de (novos) meios de obtenção de prova e de utilização de novidades tecnológicas para fins de prevenção e investigação são evidentes: os Estados precisam repensar as ferramentas e os métodos investigativos que dispõem para superar os obstáculos decorrentes da assimilação de novas tecnologias pela criminalidade, para garantir eficácia na prevenção e investigação de delitos, especialmente de crimes graves e do terrorismo. Para tanto, devem também os Estados incorporar novas tecnologias ao seu aparato investigativo, porém qualquer tentativa de incorporação deve ser precedida de base legal sólida, precisa, densa, acessível, previsível e proporcional, em observância aos princípios e garantias constitucionais e supranacionais idealizados para proteger os cidadãos contra abusos do poder estatal e garantir a mínima intromissão e restrição possível a direitos fundamentais.

De forma a ilustrar a assimilação de novas tecnologias para fins de investigação, trouxemos o exemplo dos softwares de espionagem, instrumentos que contornam todos os obstáculos referidos e possibilitam a eficaz colheita de informações sobre suspeitos de práticas ilícitas. A maior eficácia desta ferramenta significa também a possibilidade de uma maior intromissão e restrição de garantias processuais e constitucionais e de direitos fundamentais do indivíduo vigiado, o que torna o software de espionagem um método oculto de investigação de significante potencial lesivo. É em razão disso que diferentes Estados europeus vêm implementando esta novidade tecnológica em seu ordenamento jurídico com especial cautela, empregando uma racionalidade legislativa constitucionalmente orientada a fim de impedir abusos na aplicação desta gravosa ferramenta investigativa, o que infelizmente não ocorreu na legislação portuguesa. Entendemos que o legislador português tentou implementar este recurso na ordem jurídica nacional no artigo $19 .^{\circ}, \mathrm{n} .^{\circ} 2$, da Lei do Cibercrime, porém não o fez da maneira adequada, com qualidade, não havendo base legal que autorize o uso de software de espionagem para fins de prevenção ou investigação em Portugal.

A atividade preventiva e investigativa do Estado necessita de acompanhar o desenvolvimento tecnológico e social, porém essa evolução deve ser sempre promovida em confor- 
midade com as orientações constitucionais, de modo a assegurar a proteção dos direitos fundamentais e das liberdades individuais.

\section{BIBLIOGRAFIA}

ANDRADE, José Carlos Vieira de - Os Direitos Fundamentais na Constituição Portuguesa de 1976. 5. ed. Coimbra: Almedina, 2012.

ANDRADE, Manuel da Costa - Sobre as proibições de prova em processo penal. 1. $^{\text {a }}$ ed. (reimpr.). Coimbra: Coimbra Editora, 2013.

ANDRADE, Manuel da Costa - "Bruscamente no Verão passado", a reforma do código de processo penal: observações críticas sobre uma lei que podia e devia ter sido diferente. Coimbra: Coimbra Editora, 2009.

BOLDT, Martin - Privacy-Invasive Software - Exploring Effects and Countermeasure, 2007.138 f. Monografia de Licenciatura (Licenciatura em Ciência e Tecnologia da Computação)-Department of Systems and Software Engineering da Blekinge Institute of Technology, Karlskrona, 2007. [Consultado em: 23 de abril de 2018]. Disponível em: https://www.diva-portal.org/smash/get/diva2:837092/FULLTEXTo1.pdf.

CAIRES, João Gouveia de - O registo de som e imagem e as escutas ambientais. In Direito da Investigação Criminal e da Prova. Coimbra: Almedina, 2014, P. 273-298.

CLOUGH, Jonathan - Principles of Cybercrime. Cambridge: Cambridge University Press, 2010.

COLOMER, Juan-Luis Gómez - El processo penal español a comienzos del siglo XXI. Diagnóstico sobre sus principales problemas y propuesta de posibles soluciones, al hilo de la lucha contra la criminalidad organizada y la persecución de los delitos de corrupción. In InDret. Barcelona. ISSN 1698-739X. N. ${ }^{\circ}$, 2017, p. 1-59.

CONLAN, Kevin; BAGGILI, Ibrahim; BREITINGER, Frank - Anti-forensics: Furthering digital forensic science through a new extended, granular taxonomy. In Digital Investigation. Amsterdam, New York. ISSN 1742-2876. v. 18 (Supplement), 2016, p. 566-575.

FELICIONI, Paola - Lacquisizione da remoto di dati digitali nel procedimento penale: evoluzione giurisprudenziale e prospettive di riforma. Processo Penale e Giustizia. Torino. ISSN 2039-4527. N. ${ }^{\circ} 5$, 2016, p. 118-138.

FÈVRE, Paul Le - Il regime della captazzione dei dati informatici nel diritto francese. In Parola alla Difesa. Pisa. ISSN 2531-680X. N. ${ }^{\circ} 1,2016$, p. 181-183.

FILIOL, Eric - Computer viruses: from theory to application. Paris: Springer, 2005.

FILIPPI, L. - L'ispe-perqui-intercettazione "itinerante": le Sezioni Unite azzeccano la diagnosi, ma sbagliano la terapia. Parola alla Difesa. Pisa. ISSN 2531-680X. N. ${ }^{\circ}$ 1, 2016, p. 179-181.

FORGÓ, Nikolaus; HAWELLEK, Christian; KNOKE, Friederike; STOKLAS, Jonathan - The Collection of Electronic Evidence in Germany: A Spotlight on Recent Legal Developments and Court Rulings. In: New Technology, Big Data and the Law. Singapore: Springer Nature, 2017, p. 251-279.

GERCKE, Marco - Understanding Cybercrime: A Guide for Developing Countries. Geneva: International Telecommunication Union, 2011.

GUERRIER, Claudine - Révision du code de procédure pénale 2016: le nouveau régime des interceptions électroniques. [Consultado em: 02 de Outubro de 2018]. Disponível em: http://www.juriscom.net/ wp-content/uploads/2016/10/20161026penalcomm.pdf.

HUYGHE, François-Bernard - Les Écoutes Téléphoniques. Paris: Presses Universitaires de France, 2009.

MARSHALL, Angus - Digital Forensics - Digital Evidence in Criminal Investigation. Chichester: WileyBlackwell, 2008. 
A utilização de novas tecnologias no âmbito da investigação criminal e as suas limitações legais...

EDUARDO BOLSONI RIBOLI

MENDES, Paulo de Sousa - Lições de Direito Processual Penal. Coimbra: Almedina, 2015.

MENDES, Paulo de Sousa - O efeito-à-distância das proibições de prova. In Revista do Ministério Público do RS. Porto Alegre. [ISSN]. N. $.^{\circ} 74,2013$, p. 219-228.

MIRANDA, Jorge - Direitos Fundamentais. Coimbra: Almedina, 2017.

NUNES, Duarte Alberto Rodrigues - Os Meios de Obtenção de Prova Previstos na Lei do Cibercrime. Coimbra: Gestlegal, 2018.

POOL, R. L. D.; CUSTERS, B. H. M - The Police Hack Back: Legitimacy, Necessity and Privacy Implications of The Next Step in Fighting Cybercrime. In European Journal of Crime, Criminal Law and Criminal Justice. Leiden. ISSN 0928-9569. V. 25, N. ${ }^{\circ}$ 2, 2017, p. 123-144.

PRADIILLO, Juan Carlos Ortiz - La investigación del delito en la era digital: Los derechos fundamentales frente a las nuevas medidas tecnológicas de investigación - Estudios de Progreso - Fundación Alternativas. Madrid: Fundación Alternativas, 2013.

RAMALHO, David Silva - Métodos Ocultos de Investigação Criminal em Ambiente Digital. Coimbra: Almedina, 2017.

RAMALHO, David Silva - O uso de malware como meio de obtenção de prova em processo penal. Revista de Concorrência e Regulação. Lisboa. ISSN 1647-5801. A. IV, N. ${ }^{\circ}$ 16, 2013, p. 195-243.

RODRIGUES, Benjamim Silva - Da Prova Penal - Tomo II - Bruscamente... A(s) face(s) oculta(s) dos métodos ocultos de investigação criminal. Cascais: Rei dos Livros, 2010.

VALENTE, Manuel Monteiro Guedes - O Reforço dos Princípios Constitucionais na Obtenção de Prova no Mundo Digital. Corpus Delicti - Revista de Direito de Polícia Judiciária. Brasília. ISSN 2526-4265. V. 2, N. ${ }^{\circ} 3,2018$, p. 11-25.

VALENTE, Manuel Monteiro Guedes - Processo penal - Tomo I. 3. ${ }^{\text {a }}$ ed., ver., actual. e aument. Coimbra: Edições Almedina, 2010.

VELANI, Luigi Gino - Trojan horse, strumenti investigativi e diritti fondamentali: alla ricerca di un difficile equilibrio. Parola alla Difesa. Pisa. ISSN 2531-680X. N. ${ }^{\circ}$ 1, 2016, p. 173-179.

VERVAELE, J. A. E. - Surveillance and Criminal Investigation: Blurring of Thresholds and Boundaries in the Criminal Justice System? In: Reloading Data Protection: Multidisciplinary Insights and Contemporary Challenges. Dordrecht, Heidelberg, London, New York: Springer, 2014, p. 115-128. 


\title{
O Princípio da Lealdade - Provas Obtidas por Meios Proibidos nos Tribunais Internacionais
}

\author{
The Principle of Loyalty - Evidence Obtained in the \\ International Courts Using Prohibited Methods
}

MARIA JOÃO SIMÕES ESCUDEIRO'

GALILEU - REVISTA DE DIREITO E ECONOMIA - e-ISSN 2184-1845

Volume XIX · $1^{\text {st }}$ July Julho - 31 TH $^{\mathrm{H}}$ December Dezembro $2018 \cdot$ pp. 78-99

DOI: https://doi.org/10.26619/2184-1845.XIX.2.4

Submitted on July $2^{\text {th }}, 2018 \cdot$ Accepted on November $11^{\text {th }}, 2018$

Submetido em 2 de Julho, 2018. Aceite a 11 de Novembro, 2018

RESUMo Este artigo pretende abordar o princípio da lealdade no âmbito dos meios de obtenção de prova proibidos. As expetativas e anseios que recaem sobre os Tribunais Internacionais são, de tal forma altos, que colocam a Comunidade Internacional de olhos postos nas suas decisões. Neste âmbito, é relevante fazer uma análise das influências dos sistemas da Common Law e da Civil Law nesta matéria, tendo em vista uma compreensão mais abrangente das problemáticas que se levantam. Assim sendo, e tendo em conta que a law in action é mais enriquecedora do que a mera análise substantiva, propomo-nos analisar as decisões do Tribunal Europeu dos Direitos do Homem, mas apenas como precedente daquilo que são e serão as decisões dos Tribunais Penais Internacionais. É sobre estas que primordialmente incidirá o nosso estudo.

PALAVRas-CHAVE Provas proibidas; Common Law e Civil Law Tribunais Penais Internacionais; interesses da justiça; verdade dos factos.

ABSTRACT This article intends to approach the principle of loyalty within the means of obtaining prohibited evidence. The expectations and aspirations that fall on the International Court are in such high way, which put the international community's eyes on their decisions. In this context, it is relevant to analyze the influences of the Common Law and Civil Law systems, in this area, with a view to a more comprehensive understanding

1 Doutora em Ciências Jurídico-Criminais pela Universidade Católica Portuguesa. Professora Adjunta Convidada do Instituto Superior de Contabilidade e Administração de Lisboa do Instituto Politécnico de Lisboa e Professora Auxiliar do Instituto Superior de Ciências Policiais e Segurança Interna. 
of the problems that can arise. Therefore, and because we think that the law in action is more influent than simply the substantive analysis, we will consider the decisions of the European Court of Human Rights, but only as a precedent of what are and will be the decisions of International Criminal Courts. This is the primarily focus of our study.

KEYworDS Prohibited Evidence; Common Law and Civil Law; International Criminal Courts; interests of justice; truth of the facts.

\section{Princípio da Lealdade}

O princípio da lealdade diz respeito tanto à produção de prova como à condução dos indivíduos no processo. ${ }^{2}$ Como refere Germano Marques da Silva «a lealdade não é uma noção jurídica autónoma, é sobretudo de natureza essencialmente moral, e traduz uma maneira de ser da investigação e obtenção das provas em conformidade com o respeito dos direitos da pessoa e a dignidade da justiça.» ${ }^{3}$ «A atuação desleal como meio de investigação é sempre reprovável moralmente, embora nem sempre sancionada juridicamente.»4

Ao encontro das palavras de Costa Andrade, «os métodos proibidos de prova proscreve a [lei] os atentados mais drásticos à dignidade humana mais capazes de comprometer a identidade e a representação do processo penal...» $\gg^{5}$ Em face destas afirmações, que podemos facilmente adaptar ao contexto internacional, o princípio da lealdade é de suma relevância, logo obrigando a detalhada análise, tendo em consideração que se tratam de matérias pouco consensuais e, por conseguinte, muito discutidas. Tendo este facto como ponto de partida é fundamental iniciarmos esta temática com uma análise à jurisprudência do Tribunal Europeu dos Direitos do Homem (TEDH) que nesta matéria, talvez mais do que em qualquer outra, funcionará como precedente basilar.

O princípio da lealdade encontra-se em correlação com o princípio do acusatório. Sendo certo que no sistema inquisitório o Juiz detém o domínio da audiência de julgamento, cabendo-lhe a sua condução, em muitas situações o Juiz assume a produção da prova e, por isso, a audição e interrogatório das testemunhas. ${ }^{6}$

\footnotetext{
2 Albuquerque, Paulo Pinto de; 2011; p. 55.

3 Silva, Germano Marques da; 2000; pp. 66-67.

4 Idem.

5 Andrade, Manuel da Costa; 2006; p. 209.

6 Idem, p. 204.
} 
É neste contexto que, no âmbito do direito internacional, se abrem as portas a um sistema adversarial, prosseguido pelos Tribunais Internacionais. No âmbito da produção da prova definiu-se um sistema processual de partes.

\subsection{Provas Obtidas por Meios Proibidos}

Nos sistemas da Common Law, os Tribunais não têm regras de exclusão da prova, qualquer prova é admitida em julgamento, desde que tenha relevância. Todavia, os Tribunais têm imposto regras que dizem respeito à voluntariedade com que os testemunhos e depoimentos são prestados. Isto significa que os testemunhos ou depoimentos prestados de forma involuntária ou sob meios coercivos são excluídos dos procedimentos criminais.

Diferentemente, nos sistemas da Civil Law, as provas obtidas por meios proibidos não são necessariamente excluídas dos procedimentos criminais. Os Juízes devem verificar se existiu uma violação das normas criminais e se essa violação colocou em causa os interesses da parte.

Sem embargo, estas características não podem ser aplicadas de forma genérica a todos os sistemas jurídicos pertencentes a uma ou outra família jurídica, porque por exemplo, as normas processuais alemãs nesta matéria são similares ao sistema da Common Law e não ao sistema da Civil Law, como seria de esperar.?

\subsubsection{Provas Obtidas por Meios Proibidos no Tribunal Europeu dos Direitos do Homem}

O TEDH tem diversas decisões sobre esta temática porque muitos são os casos que chegam a este Tribunal. Importa analisar alguns dos que se nos afiguram como os mais paradigmáticos.

Um desses casos é Jalloh ${ }^{8}$, de 1993, em que quatro polícias à paisana viram o arguido, em duas circunstâncias diferentes, a retirar um saco da boca e entregá-lo a outra pessoa em troca de dinheiro. Acreditando que eram drogas, os polícias detiveram o arguido, mas não encontraram drogas. Pensando que se não agissem de imediato, iriam frustrar a investigação, levaram o arguido para um hospital para tomar uma substância que o fizesse vomitar. Como o arguido não tomou voluntariamente a substância, foi imobilizado pelos quatro polícias e o médico forçou-o a tomá-la através de um tubo ligado ao estômago. Para além disso, o médico injetou-o com uma substância derivada da morfina. Em consequência destas ações, o arguido regurgitou cocaína. $\mathrm{O}$ arguido afirmou que durante três dias só comeu 
sopa e que durante duas semanas sangrou pelo nariz. Tendo em conta os factos, o arguido considerou que tinha sido sujeito a tratamento desumano, o que constitui uma violação do art. $3 .^{\circ}$ da CEDH. ${ }^{9} \mathrm{O}$ TEDH deu razão ao arguido e pensamos que outra não poderia ser a sua decisão.

Num outro caso mais recente, o caso Gäfgen ${ }^{10}$, o arguido também considerou que o art. $3 .^{\circ}$ da CEDH tinha sido violado, porque a sua confissão foi obtida através de meios ilegais. $\mathrm{O}$ arguido raptou um jovem de 11 anos, filho de um banqueiro, e em ordem a descobrir o paradeiro do menor, tendo em conta que a sua vida corria perigo, na hipótese de ainda estar vivo, devido às difíceis condições climatéricas, foi ordenado ao guarda que ameaçasse o arguido com dor, mas de forma a não causar danos físicos. Não obstante, o médico atestou que o arguido tinha sofrido danos físicos. ${ }^{11}$ Conforme os dados apresentados, o TEDH considerou que tinha havido violação, por a confissão ter sido obtida de forma ilegal. Esta decisão do TEDH permite deduzir que a possibilidade de admitir prova indireta em que a prova primária foi obtida de modo ilegal não é admissível porque levaria a um julgamento injusto.

Numa outra decisão do TEDH, proferida no caso Al-Khawaja e Tahery, a opinião de dois dos seus magistrados, Sajó e Karakas, vai no sentido de considerar que se a origem da prova está inquinada, tudo o que daí derive esteja também «doente». Estes magistrados afirmam que é a primeira vez que este Tribunal, sem que se verifiquem quaisquer novas e relevantes razões, diminui o nível de proteção. Sendo assim de grande preocupação o futuro da proteção dos direitos humanos na Europa. ${ }^{12}$

Resta-nos referir um caso muito recente, que foi alvo de destaque na comunicação social, por o indivíduo em causa ser considerado o braço direito de Bin Laden na Europa. O caso Othman ${ }^{13}$ foi analisado pelo TEDH e devido a essa decisão foi impedida a sua extradição do Reino Unido para a Jordânia, por Abu Qatada não ter um julgamento justo na Jordânia, uma vez que algumas das provas usadas contra o clérigo poderiam ter sido obtidas através de tortura. ${ }^{14}$

Ainda dentro do princípio da lealdade, a figura jurídica do salvo-conduto é passível de análise.

A garantia do salvo-conduto foi - e ainda é ocasionalmente - usada para definir a segurança dada pela autoridade de um governo a um desconhecido, para que este possa entrar

9 Idem, §§ 11 a 18.

10 TEDH, Gäfgen v. Germany, Judgment, 1 June 2010.

11 Idem, § 20-22.

12 TEDH, Al-Khawaja and Tahery v. The United Kingdom, Judgment, 15 December 2011, p. 74.

13 TEDH, Othman v. United Kingdom, Judgment, 17 January 2012.

14 Idem, § 25 . 
tranquilamente e voltar a sair do território sobre o qual o respetivo governo tem jurisdição ou controlo. ${ }^{15}$

O salvo-conduto é um documento emitido por autoridades de um Estado que permite ao seu portador transitar por um determinado território, sem o perigo de ser capturado sob alegação de diversos motivos. ${ }^{16}$

Muito recentemente, esta garantia foi alvo de análise pelo TEDH no caso Adamov ${ }^{17}$, tendo sido tomada uma decisão no mínimo polémica e que gerará muita controvérsia. A decisão foi tomada com quatro votos a favor e três votos contra, o que define bem a complexidade da questão em análise e do precedente que pode representar no Direito Internacional Criminal. É por este motivo que faremos uma análise exaustiva deste acórdão, tentando dimensionar as suas incomensuráveis consequências futuras.

O requerente Adamov residia em Moscovo e, devido às suas funções de Ministro da Energia da Rússia, viu ser-lhe instaurado um processo pelos EUA, no ano de 2004. Em 2005, o requerente obteve um visto de autorização do Estado Suíço para poder visitar a filha que residia em Berna. Também em 2005, a filha de Adamov foi acusada de branqueamento de capitais pelo Juiz de Instrução do Cantão de Berna. Adamov foi informado deste facto, mas a convocação oficial do Juiz de Instrução foi feita para a morada da arguida e para o seu advogado. Aquando da sua deslocação privada à Suíça, Adamov foi testemunhar a favor da filha no Tribunal Suíço. Durante o processo, o Tribunal Suíço contactou o Estado da Pensilvânia nos EUA onde decorria o processo contra o requerente. Na decorrência deste contacto, o Ministro da Justiça dos EUA solicitou que fosse feita uma detenção provisória para uma posterior extradição, tal como estava estatuído num acordo realizado entre estes dois Estados. Em consequência, foi emitido um mandado de detenção. O requerente apresentou-se em Tribunal para testemunhar no caso da filha, e ao ser questionado sobre o motivo da sua

15 Um passaporte ou autorização de um estado neutro para as pessoas que estão autorizadas a ir e voltar em segurança e, por vezes, para levar certas coisas em segurança. De acordo com o uso comum, o passaporte é empregado em ocasiões ordinárias para permitir às pessoas circular, sempre que não exista qualquer razão para que elas não devam ir onde lhes aprouver. Diferentemente, o salvo-conduto é o nome dado ao instrumento que autoriza certas pessoas, tais como pessoas procuradas ou sobre as quais existem mandados de detenção, para irem a lugares onde não poderiam ir sem perigo, a menos que exista esta autorização do governo. Salvo-conduto é uma situação que se pode verificar em tempo de conflito internacional ou guerra, onde um estado ou uma das partes no conflito pode conceder um passe ou um documento para garantir que uma determinada pessoa possa entrar e sair do seu território sem medo de ser capturada. O intento é que a pessoa possa responder a questões geralmente fundamentais num outro processo.

16 Um exemplo desta garantia foi o "sealed train" de Lenine, que era um cidadão de um país (Rússia) em guerra com a Alemanha. Lenine foi autorizado a viajar do seu exílio na Suíça através da Alemanha, sem parar, para voltar para a Rússia. Esta situação sucedeu porque era do interesse da Alemanha, porque se acreditava que este facto iria desestabilizar a Rússia. Também na guerra do Vietname esta garantia foi muito utilizada, quer pelas tropas dos EUA, quer pelas tropas do Vietname.

17 TEDH, Case Adamov v. Suisse, 21 Juin 2011. 
deslocação à Suiça, Adamov afirmou que fora por razões particulares. Pouco tempo depois, também a Rússia fez um pedido de extradição do requerente. O requerente foi detido para ser extraditado para os EUA ou para a Rússia que, neste caso, tinha prioridade, mas apresentou um recurso dessa decisão. Por decisão de 9 de junho de 2005, o Tribunal Criminal Federal Suiço suspendeu a ordem de extradição. O recorrente que se tinha deslocado à Suíça de forma particular, mas que testemunhou, no processo penal contra a filha, afirmou que o aviso de audiência de 02 de maio de 2005 deveria ter sido dirigido de forma oficial e que, por isso, beneficiaria de proteção ao abrigo da cláusula de salvo-conduto, decorrentes da exigência de boa fé, também aplicada a uma pessoa ouvida como testemunha, que não tinha sido convocada formalmente e que se apresentou «espontaneamente» na Suíça para a audiência. Contudo, o recurso de Adamov nos Tribunais Suíços não foi aceite, nem os seus argumentos foram valorizados. É com estes contornos que este caso chega ao TEDH, o requerente considera que foi violado o seu direito à garantia do salvo-conduto, porque não foi inquirido oficialmente para testemunhar e que a sua deslocação se deveu a motivos estritamente privados e comerciais. ${ }^{18} \mathrm{O}$ Estado Suiç̧o não concorda com este argumento e considera que não foi violada a garantia de salvo-conduto. Existem vários textos legais que referem esta garantia, mas parece-nos importante referir o art. $12 .^{\circ}$ da Convenção Europeia de Entreajuda Judiciária em Matéria Penal de 20 de abril de 1959.

O TEDH considerou que Adamov não teria razão e que não tinha sido violada a garantia do salvo-conduto. Argumentou, afirmando que o requerente se deslocou livremente à Suíça, não tendo ido somente para testemunhar no processo da sua filha. Quanto à citação não ter sido realizada para o seu país de origem, o Tribunal afirma que esta foi elaborada quando o requerente já se encontrava na Suíça. Perante este facto, não existia necessidade de cooperação e não se aplicaria o direito inerente à entreajuda judiciária. ${ }^{19}$

Contudo, como supra mencionado, este caso teve três votos vencidos e os três juízes decidiram fazer uma declaração de voto. Estes magistrados consideraram que o Estado Suíço utilizou um «artifício» para fazer o requerente deslocar-se à Suíça e proceder à sua extradição, não podendo este fazer-se valer da garantia do salvo-conduto. Como referem os Magistrados vencidos, há que analisar os factos de forma cronológica e verificamos que o contacto do Juiz de Instrução do Tribunal Suíço foi realizado antes de Adamov sair da Rússia, mas só catorze dias depois é que foi emitido o pedido de extradição por parte dos EUA. Consideram que a citação não foi feita cumprindo os trâmites legais e que, por isso, o requerente estaria protegido por esta garantia. ${ }^{20}$

18 Idem, $\S \S 7-30$.

19 Idem, § 67.

20 Idem, pp. 19-24. 
Parece-nos que este acórdão do TEDH abre um precedente muito perigoso, porque ao permitir esta situação corre-se o risco de as testemunhas deixarem de confiar nesta garantia quando se deslocam para depor em Tribunal. Esta decisão de deter Adamov com fundamento numa situação que nos parece, pelo menos, pouco clara, pode levar as testemunhas a temerem que a garantia que lhes é proporcionada não seja cumprida, simplesmente porque foi utilizado um «subterfúgio» para capturar a testemunha.

O futuro o dirá, fica a ressalva do precedente que esta decisão pode representar, porque não podemos esquecer, que muitas testemunhas que se deslocam a Haia, o fazem protegidas por esta garantia. Todavia, se ela deixar de ser de facto «uma garantia» o mais provável é que comecem a ser questionadas as deslocações ao TPI. Como sabemos, os testemunhos feitos presencialmente são de suma importância no âmbito da prova dos julgamentos internacionais. Daí que, na nossa opinião, este seja um precedente no mínimo muito perigoso para a concretização da justiça internacional.

\subsubsection{Provas Obtidas por Meios Proibidos no Tribunal Militar Internacional} de Nuremberga e no Tribunal Militar Internacional do Extremo Oriente

Esta questão só de forma superficial se coloca nestes Tribunais, visto que as Cartas e os Regulamentos Processuais são pouco desenvolvidos e a valoração da prova é analisada caso a caso. A regra fundamental é a de que toda a prova com valor probatório é admissível em Tribunal. ${ }^{21}$ Todavia, esta problemática foi suscitada no caso Hans Fritzsche. O arguido afirmava que a sua confissão era ilegal porque fora conseguida sob tortura e, por isso, não foi considerada em Tribunal. ${ }^{22}$ Hans Fritzsche era responsável pela propaganda do regime. Tendo em conta as provas apresentadas, o Tribunal considerou o arguido não culpado, afirmando que as suas declarações de propaganda ao regime não incitavam o povo alemão a cometer atrocidades contra os povos conquistados. ${ }^{23}$

\subsubsection{Provas Obtidas por Meios Proibidos no Tribunal Penal Internacional para a Ex-Jugoslávia e no Tribunal Penal Internacional para o Ruanda}

De acordo com a Regra 95 dos Regulamentos Processuais de ambos os Tribunais Ad Hoc, a prova não pode ser admitida «se for obtida através de métodos que acarretem dúvidas sobre a sua obtenção ou se a sua admissibilidade for antiética, desde que cause sérios danos à integridade dos procedimentos».

21 Art. 19. ${ }^{\circ}$ da Carta do Tribunal de Nuremberga e art. $13 .{ }^{\circ}$ da Carta do Tribunal de Tóquio.

22 Harris, Whitney R., 1999, p. 541-542. Vd. Fritzsche Judgement. In http://avalon.law.yale.edu/imt/judfritz.asp.

23 Sprecher, Drexel A.;1999; Vol. II, pp. 1088-1105. 
O Estatuto e Regras Processuais dos Tribunais Ad Hoc não preveem de forma tipificada a proibição de obtenção de prova através de tortura, ou qualquer outro tratamento cruel, desumano ou degradante, mas esta proibição encontra-se bem patente na sua jurisprudência.

No Tribunal Penal Internacional para a Ex-Jugoslávia (TPIJ), o Tribunal de $1 .^{\text {a }}$ Instância esclareceu que, «numa situação em que o arguido tenha sido maltratado, sujeito a tratamentos cruéis, desumanos e degradantes, ou mesmo torturado, antes de ser presente a Tribunal, estes factos podem constituir impedimento legal do exercício da jurisdição do Tribunal. Mas, o Tribunal afirma ainda que podem estar aqui incluídas as autoridades que procederam à detenção ou mesmo os Procuradores investidos de procederem à investigação. ${ }^{24}$

«Por exemplo, num caso do Tribunal Penal Internacional para o Ruanda (TPIR), o arguido Kabiligi reclamou que tinha sido torturado aquando da sua detenção pelas autoridades do Quénia, na presença dos investigadores do Gabinete do Procurador. Segundo afirma, foi algemado e ameaçado de que regressaria ao Ruanda se não respondesse às questões dos investigadores.» ${ }^{25}$

«Todavia, os membros do Gabinete do Procurador não sustentaram nenhuma alegada tortura e a jurisprudência sobre o uso de tortura no contexto internacional é limitada.» Sem embargo, no âmbito do TEDH, existe jurisprudência em que detalhadamente se referem as circunstâncias que poderão levar os atos dos investigadores a constituírem uma tortura ou tratamento degradante. ${ }^{26}$

O que se retira desta regra é que uma prova obtida através de métodos de pouca confiança é inadmissível, e não é necessário verificar-se mais nenhuma condição. A Regra 95 foi alterada em 1995, com base em propostas dos governos dos Estados Unidos da América e do Reino Unido. ${ }^{27} \mathrm{~A}$ admissibilidade ou inadmissibilidade das provas não é mais uma questão de meios, mas de resultados. Antes da alteração, a regra tinha o mérito de desencorajar as violações dos direitos humanos na obtenção da prova ab initio. Tal como se encontra

24 Prosecutor v. Nikolic; Case No. IT-94-2-PT; Decision 9 October 2002; § 114.

25 Prosecutor v. Kabiligi; Case No. ICTR-97-34-I; 6 October 1998. Ver também Prosecutor v. Dokmanovic, Case

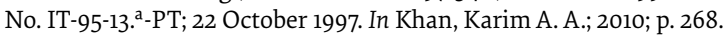

26 Idem, pp. 268-269.

27 Second Annual Report of the International Tribunal for the Prosecution of Persons Responsible for Serious Violations of International Humanitarian Law Committed in the Territory of the Former Yugoslavia since 1991. U.N. Doc. S/1994/728, 23 August 1995. Com a alteração ver ICTY Doc. No. IT/32/Rev.6, 6 October 1995. O art. 69. ${ }^{\circ}$, n. ${ }^{\circ} 7$, al. b) do Estatuto de Roma é similar à segunda parte desta regra: «Não serão admissíveis as provas obtidas com violação do presente Estatuto ou das normas de direitos humanos internacionalmente reconhecidas quando: Essa violação suscite sérias dúvidas sobre a fiabilidade das provas; ou A sua admissão atente contra a integridade do processo ou resulte em grave prejuízo deste.» 
plasmado, hoje, na Regra 95, o Tribunal tem em conta todas as circunstâncias relevantes e só exclui a prova que cause graves danos à integridade do processo. ${ }^{28}$

De facto, a Regra 95 não exige uma exclusão automática da prova obtida ilegalmente. ${ }^{29}$

No caso Delalic o Tribunal de $1 .^{\text {a }}$ Instância sustentou que:

«As declarações obtidas de forma não voluntária, ou que parecem obtidas de forma voluntária, mas que na realidade foram conseguidas através de coação, não podem ser admitidas de acordo com a Regra 95».30

Neste mesmo caso, o Tribunal de $1 .{ }^{\text {a }}$ Instância considerou que o incitamento para obter uma confissão não é uma razão suficiente para que a declaração seja excluída. ${ }^{31}$ No caso de crimes sexuais, o alegado consentimento da vítima não é permitido como defesa se estivermos perante ameaças ou situações de coação. ${ }^{32}$ Contudo, se o arguido conseguir provar ao Tribunal de $1 .^{\text {a }}$ Instância que as provas relativas ao consentimento são relevantes e credíveis, as provas sobre o alegado consentimento das vítimas podem ser admitidas, segundo a Regra 96 (iii) de ambos os Tribunais.

Esta decisão é totalmente discricionária e compete ao Tribunal. O Tribunal de $1 .{ }^{\mathrm{a}}$ Instância é composto por Juízes muito experientes, que se encontram perfeitamente aptos para lidarem com questões de prova, inclusivamente para lidar com os problemas da Regra 95. ${ }^{33}$ Somos da opinião que esta é uma temática de tal forma ambígua que não poderia ser totalmente balizada pela lei, daí a necessidade de ser uma decisão discricionária dos magistrados.

Existem dúvidas sobre algumas das matérias que cabem no âmbito de aplicação desta Regra 95. Por exemplo, a questão das comunicações intercetadas durante um conflito armado não são logo excluídas da prova, devem ser admitidas em desafio a esta Regra $95 .{ }^{34}$ Outra situação diz respeito aos depoimentos prestados de forma não voluntária, ou

28 Ver no mesmo sentido: Prosecutor v. Zigiranyirazo, Case No. ICTR-2001-73-T, 29 November 2006, § 13; Prosecutor v. Bizimungu Casimir et al., Case No. ICTR-99-50-T, 1 November 2006, § 12; 4 December 2003, § 29; Prosecutor v. Brdanin, Case No. IT-99-36-T, 3 October 2003, § 61.

29 Ver no mesmo sentido: Prosecutor v. Zigiranyirazo, Case No. ICTR-2001-73-T, 29 November 2006, § 13; Prosecutor v. Bizimungu Casimir et al., Case No. ICTR-99-50-T, 1 November 2006, § 12; Prosecutor v. Brdanin, Case No. IT99-36-T, 3 October 2003, § 54 .

30 Prosecutor v. Delalic et al., Case No. IT-96-21, 2 September 1997, § 41.

31 Ibidem, §55.

32 De acordo com a Regra 96 (ii) (B) de ambos os Tribunais Ad Hoc: «No caso de crimes sexuais... o alegado consentimento não é admissível se a vítima... tiver sido sujeita a ameaças ou tiver razões para temer violência, detenção ou coação psicológica».

33 Prosecutor v. Milosevic, Case No. IT-02-54-T, 9 June 2005, p. 5.

34 Prosecutor v. Brdanin, Case No. IT-99-36-T, 3 October 2003, § 53. 
seja, testemunhos obtidos através de meios coercivos. Esta prova não pode ser admitida de acordo com a regra referida. Se existem indícios de que foi utilizada coação na obtenção do depoimento, o ónus da prova recai sobre a parte que pretende ver a prova admitida, tendo de provar que o depoimento foi totalmente voluntário. ${ }^{35}$

Ainda neste contexto, é difícil imaginar uma situação em que seja violado o direito fundamental de ser assistido por um advogado, que não leve a uma possível exclusão, de acordo com a Regra 95. O fundamento desta exclusão seriam os prejuízos causados à integridade do processo. ${ }^{36}$

É importante analisar uma outra questão, que se relaciona com a apreensão de documentos do arguido aquando da sua detenção. O mandado de detenção não permite a apreensão dos objetos que se encontrem na posse do indivíduo detido. Contudo, o Tribunal pode autorizar a sua admissibilidade, quando a detenção seja efetuada com a cooperação das autoridades dos Estados, e algumas das legislações nacionais permitam essa revista e consequente apreensão, tanto durante o ato de detenção como posteriormente. ${ }^{37}$ Mas esta questão não é pacífica, tendo sido já questionada por um dos arguidos que afirmava que a acusação não tinha solicitado a colaboração das autoridades locais, não tendo por isso apoio na legislação nacional para efetuar a apreensão de objetos aquando da detenção. ${ }^{38}$ Nesta situação, o arguido não deve ser privado de uma defesa completa, por estar em causa uma alegada violação da soberania de um Estado. ${ }^{39}$ Contudo, para que a pretensão do arguido tenha sucesso, a defesa deve provar que a acusação estava obrigada a solicitar a cooperação das autoridades locais, mas também que esta não solicitação coloca sérias dúvidas sobre a credibilidade da prova ou que a sua admissão causaria sérios danos à integridade do processo. ${ }^{40}$

Não obstante, após rever os argumentos do arguido, o Tribunal de Recurso considerou que a defesa não conseguiu demonstrar o nexo de causalidade entre a não solicitação de cooperação das autoridades locais e a credibilidade da prova obtida e se esse comportamento antiético afetaria a integridade do processo..$^{41}$

Uma outra situação passível de contender com as proibições de prova são as comunicações, ou seja, as matérias relacionadas com o sempre controverso âmbito das escutas

35 Prosecutor v. Martic, Case No. IT-95-11-T, 19 January 2006, p. 6.

36 Ver no mesmo sentido: Prosecutor v. Zigiranyirazo, Case No. ICTR-2001-73-T, 29 November 2006, § 13; Prosecutor v. Delalic et al., Case No. IT-96-21-T, 2 September 1997, § 43.

37 Prosecutor v. Muvunyi, Case No. ICTR-2000-52A-T, 26 April 2006, § 24.

38 Prosecutor v. Naletilic and Martinovic, Case No. IT-98-34-A, 3 May 2006, § 238.

39 Idem.

40 Idem.

41 Ibidem. 
telefónicas. Como é sabido, esta prática responde a regras e requisitos formais e o problema não se coloca quanto a isso. Os problemas surgem quando estão em causa as «esferas de segredo ou das relações de confiança» ${ }^{42}$ que as leis internacionais têm definido como uma área de tutela. Neste sentido consideramos que as comunicações entre advogado e cliente, entre médico e paciente e entre assistente religioso e arguido devem ser tidas como privilegiadas. Por esse facto, não podem ser utilizadas em julgamento, logo não devem ser admitidas como prova.

Dos privilégios mencionados, o único que se encontra expressamente previsto na Regra 97 do Regulamento Processual do TPIJ é o privilégio entre advogado e cliente. O fundamento deste privilégio prende-se com a necessidade de lealdade entre advogado e cliente. Por conseguinte, as comunicações entre advogado e cliente não estão sujeitas a revelação. Este privilégio é muito característico dos sistemas adversariais em que o advogado representa e é a voz do seu cliente. Ao contrário do que parece decorrer dos sistemas da Common Law em que este privilégio tem apenas uma direção (cliente-advogado), a Regra 97 evidencia duas direções, ou seja, protegem-se as comunicações do cliente com o advogado, mas também do advogado com o cliente. ${ }^{43}$

«Embora a Regra 97 do Regulamento Processual do TPIJ defina os detalhes deste privilégio, desta previsão sobressaem principalmente as suas omissões. Por exemplo, esta Regra não especifica se as comunicações entre o arguido e os outros membros do staff de defesa estão protegidas.» ${ }^{44} \mathrm{O}$ caso paradigmático que trata esta matéria é o caso Prlic, em que a acusação solicitou ao Tribunal de Recurso que revogasse a decisão anteriormente tomada e seguisse a jurisprudência do próprio Tribunal e limitasse os contactos entre o arguido e o seu advogado enquanto o arguido presta depoimento como uma testemunha, consequentemente sob juramento, à luz da Regra $85(C) .{ }^{45}$ Com esta interpelação o Tribunal de Recurso resolve definir os limites que regulam as comunicações entre arguido e advogado, quando aquele presta testemunho no âmbito da Regra 85(C). Esta Regra permite que os arguidos possam aparecer como testemunhas na sua própria defesa. Todavia, o Tribunal de Recurso tal como o Tribunal de 1. a Instância sustentaram que há diferenças entre os depoimentos de testemunhas e de arguidos. Mesmo nesta situação o arguido conserva todos os direitos que lhe são atribuídos pelo Estatuto e pelo Regulamento Processual, nomeadamente o direito a ser assistido por um advogado à sua escolha. ${ }^{46} \mathrm{Na}$ decisão que se pretende impugnar, o Tri-

\footnotetext{
42 Andrade, Manuel da Costa; 2006; p. 287.

43 Khan, Karim A. A. and Others; 2010; p. 586.

44 Idem.

45 Prosecutor v Prlic et al., Decision Appeal Chamber, 5 September 2008, § 2 e 10.

46 Idem, § 3 e 11.
} 
bunal de $1 .^{a}$ Instância defendeu que a proibição de contacto entre as testemunhas e as partes não é, per se, aplicável às comunicações entre o arguido e o seu advogado e o Tribunal de Recurso segue a mesma orientação. ${ }^{47}$ Importa ressalvar que no geral tendemos a concordar com as decisões destes Tribunais, contudo, tal como sublinham os Juízes Shahabuddeen e Vaz apesar de ser permitida a comunicação, o advogado não pode instruir o arguido nas respostas o que podem é ter conversas «apropriadas». ${ }^{48}$

«O equilíbrio entre o direito fundamental dos arguidos a serem assistidos por um defensor em qualquer fase do processo e a proteção das comunicações entre advogado e cliente pode levantar outras questões. Por exemplo, o arguido pode sugerir tópicos que o seu defensor pode não ter considerado nos interrogatórios ou levantar questões que precisam de ser tratadas durante o seu depoimento no tribunal.»49

Por outro lado, a própria defesa pode adotar a estratégia de limitar as comunicações entre o arguido e o seu defensor enquanto aquele presta testemunho para evitar que o Tribunal duvide da espontaneidade e da veracidade das suas respostas..$^{50}$ Uma destas situações sucedeu no caso Prlic em que o defensor do arguido Praljak decidiu voluntariamente cessar o contacto com o arguido, exceto em matérias laterais, mas que não estivessem relacionadas com o testemunho. ${ }^{51}$

Todavia esta matéria levanta a questão de saber quais são as comunicações que estão protegidas por este privilégio. O TPIJ tem considerado que muitas comunicações não estão protegidas, nomeadamente o Tribunal de Recurso no caso Tadic sustentou que este privilégio não englobava os depoimentos das testemunhas prestados anteriormente..$^{22}$ Mais tarde, esta situação teve previsão legal na Regra 67 (A) do Regulamento Processual ao prever-se que a defesa deveria revelar à acusação cópias dos depoimentos de todas as testemunhas que a defesa fazia intenção de inquirir no julgamento.

Em síntese, podemos concluir que este privilégio diz respeito, principalmente, a comunicações e documentos que tenham o propósito de fornecer assistência legal ao arguido, não abrangendo todas as comunicações.

47 Idem, § 12.

48 Idem, Joint Declaration of Judge Shahabuddeen and Judge Vaz.

49 Khan, Karim A.A. and Others; 2010; p. 590.

50 Idem.

51 Prosedutor v. Prlic et al., Case No. IT-04-74-T, Transcript of 13 July 2009.

52 Prosecutor v. Tadic, Case No. IT-94-1-A, Appeal Chamber Judgment, 15 July 1999, §§ 325-326. Ver também declaração de voto do Juiz Shahabuddeen. 
Quanto às outras comunicações no âmbito de relações de confiança, os Estatutos dos Tribunais Ad Hoc não reconhecem nenhum privilégio às comunicações entre médico e paciente, ${ }^{53}$ nem mesmo entre assistente religioso e arguido. Como veremos, esta é uma matéria que foi muito desenvolvida no contexto do Tribunal Penal Internacional (TPI).

No âmbito da valoração da prova, o alcance da Regra 95 do Regulamento Processual do TPIJ é muito vasto. No caso Delalic, o Tribunal «considerou que todas as provas que sejam crediveis e tenham valor probatório são admissíveis. Para que uma prova seja considerada como credível deve relacionar-se com a matéria do processo em causa e tem de ter sido obtida sob determinadas circunstâncias, que não deixem dúvidas sobre a sua natureza e qualidade e que não tenham violado quaisquer direitos fundamentais dos arguidos». Concretiza-se esta situação se a prova tiver sido obtida de acordo com os parâmetros da Regra 95 do Regulamento Processual, ou seja, através de métodos que não causem prejuízos graves à integridade dos procedimentos. Não existem quaisquer dúvidas que os depoimentos obtidos de forma não voluntária, ou que somente aparentemente são obtidos de forma voluntária, mas que na realidade o foram através de métodos opressivos, se enquadram na Regra 95 do Regulamento Processual. Um outro elemento que consta da Regra 95 é a integridade, que é a base de um julgamento justo.

No que diz respeito aos depoimentos dos arguidos, a acusação tem de provar de forma convincente e para que não restem quaisquer dúvidas que o depoimento foi feito voluntariamente. Caso contrário, como se infere do caso Delalic, este depoimento não pode ser admitido com base na Regra 95. O mesmo sucede com os depoimentos prestados voluntariamente, mas obtidos através de meios coercivos. ${ }^{54}$ Ainda tendo em conta a Regra 95, há certas provas, tal como aquelas que foram obtidas numa busca policial ${ }^{55}$, durante uma investigação irregular ${ }^{56-57}$, ou simplesmente se tiver existido uma violação do Regulamento Processual, que serão consideradas inadmissíveis. As irregularidades verificadas durante o processo serão suficientes para excluir as provas obtidas. Parece-nos que a Regra 95 é abrangente o suficiente para sancionar condutas incorretas ou negligentes dos investigadores, sendo ou não o Tribunal responsável pelos seus atos.

53 Neste âmbito é relevante analisar o caso Prosecutor v. Furundzija, Case No. IT-95-17/1, em que o Tribunal de 1. ${ }^{a}$ Instância reabriu o caso para que fossem revelados à defesa todos os documentos médicos de uma das testemunhas que teriam levado à condenação do arguido. Todavia, apesar do acompanhamento medico de que a testemunha necessitava porque sofria de Stress Pós Traumático, o Tribunal considerou que ela poderia gerar prova credível. Sem embargo, muitas foram as vozes que criticaram esta decisão de revelar material médico. Decision 16 July 1998; Judgment, 10 December 1998, §§ 109-113.

54 Prosecutor v. Delalic et al., 2 September 1997, §§ 41-42.

55 Prosecutor v. Kordic and Cerkez, 25 June 1999.

56 Prosecutor v. Delalic et al., 25 September 1997, § 45.

57 Prosecutor v. Delalic et al., 16 November 1998, § 65. 
Contudo, numa outra decisão do TPIJ, também no caso Delalic, o Tribunal sustentou que estaríamos perante um obstáculo muito perigoso para a administração da justiça, se as provas que fossem relevantes e com valor probatório não pudessem ser admitidas, somente devido a uma violação, de menor importância, das regras processuais, sendo que o Tribunal não está obrigado a aplicá-las. Neste caso, o Tribunal admitiu uma série de documentos como prova em nome dos interesses da justiça.

O Tribunal reservou-se o direito de exercer a sua discricionariedade na decisão de excluir provas, sempre que forem obtidas violando os direitos humanos..$^{8}$

Os criadores do Regulamento Processual escolheram especificamente não definir de forma automática a exclusão de provas ilegalmente obtidas e optaram por deixar esta matéria para ser regulamentada pelas Regras 89 e 95. Torna-se óbvio que quer nos tribunais nacionais, quer nos tribunais internacionais, não é certo que uma prova obtida de forma ilegal seja, a priori, inadmissível.

Há que ter em conta as circunstâncias da sua obtenção, bem como a credibilidade que traz ao processo. ${ }^{59}$

Somente se estes pressupostos não se verificarem e se a obtenção ilegal trouxer graves danos para o processo, ou violar os direitos fundamentais, é que deve ser excluída. Como podemos sintetizar, esta questão dá azo a muita controvérsia e mesmo perante esta explicitação é-nos difícil tomar uma posição. Se, por vezes, tendemos a concordar com o Tribunal, como no caso Delalic em que foram admitidos certos documentos porque o Tribunal considerou que tinha existido somente uma violação de menor importância das Regras Processuais; por outro lado, questionamo-nos: (1) qual a linha que delimita o que se entende por violação de menor importância; e (2) até onde pode ir a discricionariedade do Tribunal com o fundamento de que se está a beneficiar os interesses da justiça.

De facto, as nossas incertezas são muitas, mas parece-nos que nesta matéria o TPIJ alargou em demasia a admissibilidade das provas potencialmente proibidas. Concordamos que este é um poder que só pode ser atribuído aos magistrados, porque não há outra forma de regulamentar esta matéria. Não obstante, consideramos que esta discricionariedade deve ser cuidadosamente administrada.

Finalmente, é relevante fazer uma reflexão sobre a questão do respeito pela garantia do salvo-conduto. Esta garantia foi um recurso utilizado em diversas decisões do TPIJ e do TPIR. Se ponderarmos bem o conteúdo desta garantia, verificamos que ela é fundamental para que certos indivíduos se predisponham a testemunhar em Tribunal. Muitas vezes, só

58 Prosecutor v. Delalic et al., 9 February 1998, §§ 20, 21 e 23.

59 Prosecutor v. Radoslav Brdjanin, 3 October 2003, §§ 28, 57 e 61. 
com a garantia de que não serão detidas ou capturadas é que certas pessoas se apresentam em Tribunal. O que sucedeu no caso Karadzic ${ }^{60}$, no qual a acusação solicitou ao Tribunal que concedesse a garantia de salvo-conduto à testemunha Momcilo Mandic. ${ }^{61}$ Esta testemunha já tinha beneficiado desta garantia em duas situações anteriores, mas de forma confidencial. O Tribunal considerou que a garantia de salvo-conduto é um instrumento de utilização comum no direito internacional e na prática deste Tribunal, onde se permite que seja concedida uma imunidade limitada em circunstâncias específicas, como é o caso. ${ }^{62}$ No caso Gotovina também foi utilizada a garantia do salvo-conduto para permitir o testemunho de Kosta Novakovic. Este caso tem a particularidade de primeiramente a garantia ter sido concedida como confidencial, mas depois o Tribunal ter decidido que não existiam motivos ponderáveis para que não fosse tornada pública. ${ }^{63}$ Para além destes casos, também no caso Delalic esta garantia foi concedida a oito testemunhas de um dos arguidos, Esad Landzo, consideradas como suspeitas pela acusação e que, somente se beneficiassem desta garantia, se deslocariam para depor em Tribunal. ${ }^{64}$

No TPIR esta garantia também foi utilizada no caso Nyiramasuhuko, no qual a defesa pretendia que fosse concedida uma série de medidas de proteção a uma testemunha. Esta testemunha era considerada fundamental para o processo, mas tinha uma situação bastante complexa porque, para além da garantia de salvo-conduto, residia na Bélgica e o Estado belga já tinha emitido uma ordem de expulsão que ainda não tinha sido concretizada. O Tribunal negou parte das pretensões da defesa, mas concedeu a garantia de salvo-conduto, com a ressalva de que a testemunha não poderia usar o motivo de doença para se manter na Tanzânia, e se praticasse algum ato ilícito durante esse período também não poderia invocar esta garantia. ${ }^{65}$ Finalmente, no caso Nzirorera, verifica-se também uma especificidade, considerando que o arguido pretendia que a garantia de salvo-conduto não se limitasse aos crimes que se encontravam sob a jurisdição do Tribunal. O Tribunal não concordou e rejeitou o pedido da defesa. ${ }^{66}$

Daqui decorre a incomensurável importância da garantia do salvo-conduto nos Tribunais Penais Internacionais e que em face da referida decisão do $\mathrm{TEDH},{ }^{67}$ pode estar em equação.

60 Prosecutor v. Radovan Karadzic, Case No. IT-95-5.

61 Idem, 16 June 2010, § 1 .

62 Idem, $\S \S 7-11$.

63 Prosecutor v. Gotovina et al., Case No. IT-06-90-T, 12 May 2009.

64 Prosecutor v. Delalic et al., Case No. IT-96-21, 25 June 1998.

65 Prosecutor v. Pauline Nyiramasuhuko, Case No. ICTR-97-21-T, 17 June 2005.

66 Prosecutor v. Karemera et al., Case No. ICTR-98-44-T, 24 March 2009.

67 TEDH, Case Adamov v. Suisse; 21 Juin 2011. 


\subsubsection{Provas Obtidas por Meios Proibidos no Tribunal Penal Internacional}

Ao contrário do que sucede nos Tribunais Ad Hoc, esta matéria está expressamente prevista no Estatuto de Roma. O art. 55. ${ }^{\circ}$, n. ${ }^{\circ} 1$, al. b) refere que «no decurso de um inquérito nenhuma pessoa poderia ser submetida a qualquer forma de coação, intimidação ou ameaça, tortura ou outras formas de penas ou tratamentos cruéis, desumanos ou degradantes.» Este direito constitui uma salvaguarda para que nenhuma pessoa seja sujeita a tratamentos desumanos enquanto decorrem as atividades do TPI. Por outro lado, garante-se a proteção de qualquer pessoa de sofrer atos ilegais praticados pelas autoridades que conduzem as investigações. ${ }^{68}$ Este direito está em conformidade com o direito à não autoincriminação e o direito ao silêncio.

Também neste contexto, é relevante integrar o conteúdo inerente às relações de confiança, designadamente as comunicações privilegiadas ou não entre defensor e cliente, médico e paciente e assistente religioso e arguido.

O TPI não fornece, de forma expressa, uma proteção para a relação defensor-cliente.

Diferentemente, os meandros da relação médico-paciente encontram-se tipificados na Regra 73 do Regulamento Processual do TPI, na qual se qualificam as comunicações entre estes sujeitos de privilegiadas. Por exemplo, o caso Thomas Lubanga Dyilo é pródigo em situações difíceis. Referimo-nos aos depoimentos de crianças-soldado e de vítimas de violência sexual, em que o testemunho pode ser muito traumatizante e estas podem não se encontrar em situações psicologicamente capazes. O TPI tem sustentado a necessidade de prestar apoio a estas testemunhas, incluindo aconselhamento psicológico prestado pelo TPI. ${ }^{69-70}$ A questão que se levanta é a de saber se as comunicações destas testemunhas com os profissionais médicos devem permanecer confidenciais. ${ }^{71}$

Na nossa opinião é preciso ter muito cuidado com o tratamento a atribuir a estas comunicações, que primeiramente parecem dever permanecer confidenciais, mas com fundamento na necessidade de descoberta da verdade, podem determinadas comunicações ser reveladas, em certas circunstâncias. Sendo relevadas, devem ficar sujeitas ao contraditório, respeitando os direitos dos arguidos.

68 Cassese, A. and Others; 2002; p. 1197.

69 Vd. Prosecutor v Thomas Lubanga Dyilo; Case No. ICC-01/04-01/06, Transcript of 28 January 2009 e Transcript of 29 January 2009.

70 Art. $43 .^{\circ}$ n. ${ }^{\circ} 6$ do Estatuto de Roma - «O secretário criará, no âmbito da Secretaria, uma Unidade de Apoio às Vítimas e Testemunhas. Esta Unidade, em conjunto com o Gabinete do Procurador, adoptará medidas de proteção e dispositivos de segurança e prestará assessoria e outro tipo de assistência às testemunhas e vítimas que compareçam perante o Tribunal e a outras pessoas ameaçadas em virtude do testemunho prestado por aquelas. A Unidade incluirá pessoal especializado para atender as vítimas de traumas, nomeadamente os relacionados com crimes de violência sexual.»

71 Khan, Karim A. A. and Others; 2010; p. 594. 
Por outro lado, «nas comunicações entre assistente religioso e arguido o TPI definiu dois sistemas. Primeiro, o TPI deve prestar particular atenção às comunicações entre o arguido e o assistente religioso. Nestes casos, o TPI deve determinar ou não a verificação de um privilégio inerente a essas comunicações. Importa aqui saber se as comunicações foram ou não realizadas em confissão. $>^{72}$

A Regra 73 deve ser interpretada em conjugação com o art. $67 .^{\circ}$ e a Regra 63. O que significa que não podem ser esquecidos os direitos dos arguidos, nem os seus direitos à revelação da prova. Por conseguinte, se estes privilégios excluem a admissibilidade de prova potencialmente relevante, o Tribunal deve ser cauteloso por forma a prevenir abusos. Este privilégio pode ser utilizado de forma imprópria como proteção das investigações. Todavia, este privilégio não é limitado à acusação, ele aplica-se também à defesa.

A problemática do efeito à distância é uma das questões mais relevantes neste âmbito. Esta matéria surge nos casos em que a obtenção de uma determinada prova torna possível a descoberta de novos meios de prova contra o arguido ou contra terceiro. Neste contexto, cabe questionar se a proibição de valoração que eventualmente inquine a prova primária ou direta se comunica, e em que medida, às provas secundárias ou indiretas, impondo a sua exclusão em cadeia. Como facilmente se representará, o problema ganha particular relevo prático-jurídico nas hipóteses frequentes em que a realização de buscas, apreensões, exames, detenções... ou o recurso a métodos proibidos de prova, como a tortura, levam o arguido a comprometedoras declarações autoincriminatórias.

A priori, a prova proibida contamina a restante prova se houver um nexo de dependência cronológica, lógica e valorativa entre elas.

A regra para excluir provas ilegais verifica-se em praticamente todos os sistemas, quer no sistema adversarial, quer no inquisitorial. O sistema inquisitorial realça as questões processuais, o que significa que a prova será excluída se for obtida com violação das normas processuais de justiça. Por seu lado, o sistema da Common Law realça principalmente as questões da segurança, logo, se os efeitos dos procedimentos são mais prejudiciais que o seu valor probatório, a prova não poderá ser admitida. Se a admissão da prova puser em causa a justiça do processo, também deve ser excluída, de acordo com o sistema da Common Law. ${ }^{73}$

72 Idem, p. 595.

73 Tal como refere Costa Andrade, esta questão é mais linear do lado da experiência americana. «Desde as primeiras décadas do século passado - mais precisamente desde os marcantes Silverthorne Lumber Co. v. United States (1920) e Nardone v. United States (1939) - vigora aqui, de forma tão pacífica como generalizada, o princípio do efeito à distância das exclusionary rules. Ou, na expressão cunhada pelo Justice Frankfurter, $a$ fruit of the poisonous tree doctrine. Consensual é outrossim a fundamentação para que invariavelmente apontam os tribunais e tratadistas americanos quando se interrogam sobre a intencionalidade político-criminal que 
A questão do efeito à distância não se encontra expressamente definida nos diplomas legais do TPI..$^{74}$ Todavia, o art. $69 .{ }^{\circ}$, n. $^{0}$ 7, do Estatuto de Roma, prevê que não são admissíveis as provas obtidas com a violação do Estatuto. Neste sentido, parece que a prova primária obtida de forma ilegal contaminará a prova que dela deriva, mas como tudo o que não está tipificado na lei, esta interpretação é passível de alterações e adaptações caso a caso. Mais uma vez, ficará nas mãos dos juízes do TPI, que integrarão devidamente estas matérias e farão da sua jurisprudência pontos de partida para a concretização desta temática.

O TPI, no caso Bemba, defendeu que a concretização dos conceitos do art. $69 .{ }^{\circ}$, n. $^{\circ} 7$, deve ser determinada caso a caso. O Tribunal de 1. ${ }^{a}$ Instância considerou que a conjugação deste artigo com a Regra 71 do Regulamento Processual permite concluir que nenhuma prova é per se inadmissivel. ${ }^{75}$

Ponderando a garantia do salvo-conduto, hoje, no âmbito do TPI, esta garantia está prevista no art. $26 .^{\circ}$ do Acordo realizado entre o TPI e a Holanda, o estado que recebe o Tribunal. ${ }^{76}$ Julgamos que será o TPI quem mais poderá ser alvo das consequências da decisão do $\mathrm{TEDH}^{77}$, porque o receio pode levar muitas pessoas a não se deslocarem ao Tribunal.

\section{Conclusão}

No direito internacional criminal, os direitos dos arguidos são o espelho da evolução das garantias dos direitos humanos que têm influenciado a proteção dos direitos dos arguidos durante os procedimentos judiciais. Neste contexto, é importante concluir sobre a admissibilidade ou não das provas proibidas.

A exclusão de provas ilegais acontece em praticamente todos os sistemas jurídicos. Hoje não se concebe o direito, a justiça, com a admissibilidade de provas obtidas de forma

empresta racionalidade teleológica a este regime. Apesar de tudo, a vigência desta doutrina no direito americano está longe de ser absoluta e irrestrita. Por vezes pode legitimar-se a valoração de provas secundárias sempre que elas foram ou poderiam ter sido obtidas por via autónoma e legal, à margem da exclusionary rule que impende sobre a prova primária. Tal, só ocorrerá nos casos em que a produção da prova secundária, por via independente e legal, se possa, em concreto, considerar iminente. Por outro lado, temos a experiência alemã que, num primeiro confronto, deixa sobressair a sua extrema complexidade. O que, à partida e ao contrário do que sucede com o direito americano, desaconselha o recurso a enunciados axiomáticos, tendencialmente generalizadores do género: o direito alemão não reconhece qualquer efeito à distância às proibições de prova. Com o passar dos tempos e contestando este entendimento, ganham cada vez mais peso na doutrina alemã ou autores que se pronunciam a favor de um efeito à distância das proibições de prova. Hoje, são sobretudo as soluções compromissórias ou mistas que vêm colhendo o aplauso maioritário dos autores alemães.» In Andrade, Manuel Costa de, 2006, pp. 170-182.

74 Khan, Karim and Others; 2010; p. 241.

75 Prosecutor v. Jean-Pierre Bemba Gombo, Case No. ICC-01/05-01/08, 3 May 2011, pp. 7-20.

76 Headquarters Agreement between the International Criminal Court and the Host State, 1 March 2008.

77 Vd. TEDH, Case Adamov v. Suisse; 21 Juin 2011. Decisão analisada no ponto referente às provas obtidas por meios proibidos. 
ilegal. A atualidade da jurisprudência do TEDH sobre esta matéria denota bem esse facto, visto que não se podem aceitar práticas que violam as normas de direito.

Nesta matéria, como em tantas outras, os Tribunais Internacionais são influenciados pela jurisprudência do TEDH e, em consequência, o TPIJ e o TPIR, e no mesmo sentido, o TPI, não admitem como prova a que é obtida através de métodos ilegais. Mais complexa é a questão de saber se a prova proibida contamina a restante prova que com ela tenha alguma relação de dependência. Quanto a esta problemática, analisámos uma série de teorias e de conclusões. Como supra referido, o TPIJ apresenta-nos algumas soluções para esta questão, mas ainda aguardamos que a questão se coloque ao TPI para podermos constatar qual o caminho a seguir no âmbito do direito internacional. Todavia, apraz-nos avançar com uma possível solução, que nos parece vir a ser no mesmo sentido do TPIJ. Face ao exposto, serão admitidas as provas que tenham valor probatório, mesmo que de alguma forma na sua origem esteja uma prova obtida através de meios proibidos

Podemos afirmar que os Tribunais de Nuremberga e de Tóquio não são um verdadeiro precedente em matéria de direitos dos arguidos nem mesmo na regulamentação do processo investigativo. O que sucede muito provavelmente devido à tensão que existia no pós-guerra entre as partes envolvidas no conflito, e talvez por isso estes julgamentos tenham sido tantas vezes criticados por serem a «justiça dos vencedores». ${ }^{78}$ Uma outra justificação, que pode ajudar a compreender esta lacuna em relação aos direitos dos arguidos, é a falta de Tratados Internacionais que regulassem estas matérias e que nessa altura eram ainda inexistentes.

Diferentemente dos Tribunais Militares de Nuremberga e de Tóquio, o TPIJ e o TPIR e, também, o TPI, preveem as garantias dos arguidos de forma mais aprofundada e definida.

Após esta análise, poderemos verificar que o Estatuto de Roma concretiza de forma mais clara e explícita uma aproximação quer ao adversarial, quer ao inquisitorial. Por exemplo, algumas garantias que não eram muito evidentes nos Estatutos dos Tribunais Ad Hoc tornaram-se agora mais definidas, como é o caso do direito do arguido a ser ouvido de forma justa e sem limitações ou a obrigação da acusação recolher não só provas incriminatórias, mas também provas desculpatórias. Nesta matéria, o sistema criado para regular a intervenção do TPI aproxima-se do sistema inquisitorial, no qual o interesse da justiça é a procura da verdade dos factos e não só a prova da culpa do arguido. Esta é uma característica de ambos os sistemas jurídicos onde o objetivo primordial é a descoberta da verdade, mas para se atingir essa verdade utilizam-se meios diferentes. Decorre desta ilação que o princípio da 
igualdade inerente aos tribunais referenciados alarga o seu âmbito de aplicação por forma apreender características de ambos os sistemas jurídicos de forma harmoniosa.

Por outro lado, no que diz respeito aos meios de obtenção de prova e o efeito à distância verifica-se, no sistema criminal internacional, uma aproximação ao sistema adversarial em detrimento de um sistema mais rígido que é o inquisitorial. Quanto a esta matéria há uma maior flexibilidade na admissibilidade de prova tal como sucede no sistema adversarial. Verifica-se que nestes Tribunais refletem-se ainda, ao nível dos seus Regulamentos Processuais, muitas características do sistema adversarial, principalmente, os Tribunais Ad Hoc, nos quais estas Regras foram elaboradas pelos magistrados, que na sua maioria advinham de Estados da Common Law.

\section{BIBLIOGRAFIA}

ALBUQUERQUE, Paulo Pinto de

—, 2011: Comentário do Código de Processo Penal à luz da Constituição da República e da Convenção Europeia dos Direitos do Homem, Universidade Católica.

ANDRADE, Manuel da Costa

—, 2006: Sobre as Proibições de Prova em Processo Penal, Coimbra Editora.

CASSESE, Antonio; Gaeta, Paola and Jones, Jonh R. W. D.

— 2002: The Rome Statute of the International Criminal Court: A Commentary: Materials, Volume I and II. New York, Oxford University Press.

HARRIS, Whitney R.

— 1999: Tyranny on Trial - The Trial of the Major German War Criminals at the End of World War II at Nuremberg, Germany, 1945-1946. Dallas, Southern Methodist University Press.

KHAN, Karim A. A.; Buismen, Caroline and Gosnell, Christopher

—, 2010: Principles of Evidence in International Criminal Justice. Oxford University Press.

MINEAR, Richard H.

—, 2001: Victors' Justice - The Tokyo War Crimes Trial. Center For Japanese Studies The University of Michigan.

MURRAY, Juliana

—, 2010: Assessing Allegations: Judicial Evaluation of Testimonial Evidence in International Tribunals. In 10 Chicago Journal of International Law, Winter 2010. Artigo.

SILVA, Germano Marques da

- 2000: Curso de Processo Penal, Vol. I, Editorial Verbo.

SPRECHER, Drexel A.

—, 1999: Inside the Nuremberg Trial - A Prosecutor's Comprehensive Account, Vol. I e II. Maryland, University Press of America, Inc. 


\section{JURISPRUDÊNCIA}

\section{Tribunal Europeu dos Direitos do Homem}

Adamov v. Suisse

ECHR, Judgment, 21 Juin 2011

Al-Khawaja and Tahery v. United Kingdom

ECHR, Judgment 15 December 2011

Gäfgen v. Germany

ECHR, Judgment 1 June 2010

Jalloh v. Germany

ECHR, Judgment, 11 July 2006

Othman v. United Kingdom,

ECHR, Judgment, 17 January 2012

\section{Tribunal Penal Internacional para a Ex-Jugoslávia}

Brdanin and Talic (IT-99-36)

Decision on the Defence "Objection to Intercept Evidence", 3 October 2003

Delalic and Others (IT-96-21)

- Decision on Zdavko Mucic's Motion for the Exclusion of Evidence, 2 September 1997

- Decision on the Motions for the Exclusion of Evidence by the Accused, Zejnil Delalic, 25 September 1997

- Decision on the Tendering of Prosecutor Exhibits 104-108, 9 February 1998

- Order Granting Safe Conduct to Defence Witnesses, 25 June 1998

- Judgment, 16 November 1998

Dokmanovic (IT-95-13A)

- Decision on the Motion for Release by the Accused, 22 October 1997

Furundzija (IT-95-17/1)

- Decision, 16 July 1998

Gotovina and Others (IT-01-45-PT)

- Order to Lift the Confidential Status of the Trial Chamber's Order of 3 November 2008, 12 May 2009

Karadzic, Radovan (IT-95-5)

- Decision on the Prosecution's Motion for Safe Conduct for Witness Momcilo Mandic, 16 June 2010

Kordic and Cerkez (IT-95-14/2)

- Decision Stating Reasons for Trial Chamber's Ruling of 1 June 1999 Rejecting Defence Motion to Suppress Evidence, 25 June 1999

Martic, Milan (IT-95-11)

- Decision Adopting Guidelines on the Standards the Admission of Evidence, 19 January 2006

Milosevic (IT-02-54)

- Decision on Prosecution Motion for Voir Dire Proceeding, 9 June 2005

Naletilic and Martinovic (IT-98-34)

- Appeals Chamber Judgment, 3 May 2006

Nikolic, Dragan (IT-94-2-AR73)

- Decision on Defence Motion Challenging the Exercise of Jurisdiction by the Tribunal, 9 October 2002 
Prlic and Others (IT-04-74)

- Decision on Prosecution's Appeal against Trial Chamber's Order on Contact between the Accused and Counsel during an Accused's Testimony pursuant to Rule 85(c), 5 September 2008

- Transcript, 13 July 2009

Tadic (IT-94-1)

- Appeals Chamber Judgment, 15 July 1999

\section{Tribunal Penal Internacional para o Ruanda}

Bizimungu, Casimir (ICTR-99-45)

- Decision on Prosper Mugiraneza's Renewed Motion to Exclude His Custodial Statements from Evidence, 4 December 2003

- Decision on Casimir Bizimungu, Justin Mugenzi and Jerome Bicamumpaka's Written Submissions Concerning the Issues Raised at the Hearing of 31 March 2006 in Relation to the Cross Examination of Witness Augustin Kayinamura, 1 November 2006

Kabiligi and Ntabakuze (ICTR-97-34-I \& ICTR-97-30-I)

- Decision on the Defence Motion to Lodge Complaint and Open Investigations into Alleged acts of Torture Under Tules 40 (C), 6 October 1998.

Karemera and Others (ICTR-98-44)

- Decision on Joseph Nzirorera's Motion for Reconsideration of Certificate of Safe Conduct, 24 March 2009

Muvunyi (ICTR-2000-52A)

- Decision on Prosecution's Motion Pursuant to Trial Chamber's Directives of 7 December 2005 for Verification of the Authenticity of Evidence Obtained out of Court Pursuant to Rules 89(C) \& (D), 26 April 2006

Nyiramasuhuko, Pauline and Ntahobali, Arsène Shalom (ICTR-97-21)

- Decision on Nyiramasuhuko's Strictly Confidential Ex-Parte-Under Seal - Motion for Additional Protective Measures for Defence Witness WBNM, 17 June 2005

Zigiranyirazo (ICTR-2001-73-T)

- Decision on the Voir Dire Hearing of the Accused's Curriculum Vitae, 29 November 2006

\section{Tribunal Penal Internacional}

Jean-Pierre Bemba Combo (ICC-01/05-01/08OA3)

- Judgment on the Appeals of Mr. Jean-Pierre Bemba Gombo and the Prosecutor Against the Decision of Trial Chamber III entitled "Decision on the Admission into Evidence of Materials Contained in the Prosecution's List of Evidence", 3 May 2011

Thomas Lubanga Dyilo (ICC-01/04-01/06)

- Transcript, 28 January 2009 


\title{
Desafiar Mamon: O Estado das Contas Públicas
}

\author{
Challenging Mammon: The State of Public Accounts
}

JOSÉ EMANUEL MATOS TORRES'

GALILEU - REVISTA DE DIREITO E ECONOMIA * e-ISSN 2184-1845

Volume XIX $\cdot 1^{\text {st }}$ July Julho $-31^{\text {TH }}$ December Dezembro $2018 \cdot$ pp. 100-130

DOI: https://doi.org/10.26619/2184-1845.XIX.2.5

Submitted on July $2^{\text {th }}, 2018$. Accepted on November $11^{\text {th }}, 2018$

Submetido em 2 de Julho, 2018 . Aceite a 11 de Novembro, 2018

RESUMO Vivemos hoje tempos de grande euforia económica. As exportações crescem significativamente, muito à boleia do turismo, o investimento dá sinais de querer emergir, o desemprego desce, a inflação está controlada. No setor público atinge-se o défice mais baixo desde o antigo regime. Tudo parece estar a correr bem. Mas será que sim?

A «besta negra» das contas nacionais, a dívida pública, não para de crescer em termos absolutos e relativos. Esse comportamento poderia não ser tão preocupante se estivéssemos certos que os motivos que estão por detrás fossem virtuosos. Mas os dados apontam em sentido contrário. Efetivamente, não é só o stock de dívida e os inerentes encargos que merecem preocupação. Mais importante que tudo é a sua origem, natureza e composição. As contas públicas sofrem o efeito de um vírus silencioso, ainda assintomático, que corrói a sua sustentabilidade, na linha do preconizado pelos clássicos, como Keynes - com a sua teoria da regra de ouro orçamental, tão ignorada que é - e, entre nós, José Teixeira Ribeiro. E ninguém parece querer ligar a isso.

Os mecanismos e as regras de controlo assumidas pela UE, para além das dúvidas na sua cientificidade, bondade e eficácia, não obrigam a recentrar a questão no essencial. Por isso muito terá que ser feito a nível interno para obstar aquilo que parece inevitável, se a situação não se inverter: a perda sistemática da soberania financeira nacional, podendo culminar no quarto resgate financeiro da era democrática.

Palavras-chave Dívida Pública. Dívida interna e externa. Regra de ouro do orçamento de Keynes. Soberania financeira nacional. Controlo das contas públicas. Pacto de Estabilidade e Crescimento da União Europeia.

1 Licenciado em Ciências Policiais e em Gestão. Diretor Nacional Adjunto para a Unidade Orgânica de Logística da PSP 
ABSTRACT We live in times of great economic euphoria. Exports grow significantly, much thanks to the tourism industry, investment appears to be emerging, unemployment is falling, and inflation is controlled. The public sector has reached the lowest deficit since the old regime. Everything seems to be going well. But is it?

The "black beast" of national accounts, public debt, has not ceased to grow in absolute and relative terms. This behaviour might not be so disturbing if we were certain that the motives behind it were good. But the data points to the opposite direction. Effectively, it is not just the debt stock and the inherent problems that deserve concern. More important than anything is its origin, nature and composition. Public accounts suffer from a silent virus, still asymptomatic, which erodes its sustainability, along the line of the classics, as Keynes - with his theory of the budget golden rule, much ignored - and our own José Teixeira Ribeiro. And no one seems to care.

The mechanisms and control rules adopted by the EU, in addition to doubts as to their scientific, worthy and effective nature, do not require a reorientation of the question in its main points. So, much will have to be done internally to prevent what seems inevitable if the situation is not reversed: the systematic loss of national financial sovereignty, which could culminate in the fourth financial bailout of the democratic era.

KEYworDS Public Debt. Internal and external debt. Keynes Budget Golden Rule. National financial sovereignty. Control of public accounts. Stability and Growth Pact of the European Union.

\section{Introdução}

Portugal assiste atualmente a uma transformação socioeconómica de grande significado, ancorada no aumento da produtividade, na capacidade de inovação e numa maior competitividade à escala mundial, não tanto pela quantidade produzida - não apresenta grande disponibilidade de fatores de produção nem um mercado interno significativo, depois da perda do efeito escala que detinha com as ex-colónias -, mas sim pela subida dos seus produtos na cadeia de valor acrescentado.

Para ser bem-sucedido neste duro caminho do sucesso económico, o único que pode gerar bem-estar e tranquilidade aos cidadãos residentes, o país precisa de facto de contas públicas estabilizadas e controladas. Só assim conseguirá aliviar o elevado esforço que exige aos agentes económicos sob a forma de impostos, taxas e outras contribuições, embora indubitavelmente ainda exista espaço para melhorar os índices de eficácia e eficiência fiscal e de aliviar a despesa corrente. 
O ano de 2016, no que toca ao défice orçamental, foi o melhor de sempre desde a implantação da democracia. É, sem dúvida alguma, motivo para regozijo, para mais quando outros indicadores de cariz socioeconómico, como o desemprego, a criação de riqueza e as exportações tiveram melhorias substanciais, significando afinal que, como dizíamos há tempos², havia alternativas a uma linha austeritária ortodoxa. Mas os velhos problemas orçamentais, desde logo a inexistência de forma continuada de superavits correntes e o enorme stock de dívida pública, em especial os efeitos que emergem da sua peculiar natureza e origem, continuam a provocar enormes dores de cabeça aos sucessivos governantes. Como iremos procurar demonstrar, o desempenho orçamental do Estado tem, ao longo destas últimas quatro décadas, sofrido os efeitos de um vírus nocivo, silencioso, que se fortalece continuamente, mesmo de forma assintomática.

A sujeição severa a regras inscritas quer no Pacto de Estabilidade e Crescimento (PaEC) quer no Tratado Orçamental (TO), aceites dogmaticamente pelo establishment europeu, pode não ser assim tão tranquilizadora. Demonstraremos as nossas dúvidas quanto à sua lógica e virtuosidade. Na verdade, ninguém discute a necessidade de haver regras num espaço europeu com moeda única. Mas quando tal implica sacríficos brutais aos povos europeus, em especial nos países com menor dimensão económica, a sua consistência, credibilidade e validade científica têm de ser absolutamente «à prova de bala». Analisemos para já a trajetória do nosso maior problema à luz das mesmas regras: a dívida soberana.

\section{Como evoluiu a dívida pública até hoje}

Por altura da eclosão generalizada da crise financeira iniciada nos EUA, em 2008, apenas Grécia (109\% do PIB), Itália (102\%) e Bélgica (92\%) registavam dívidas soberanas superiores a $90 \%{ }^{3}$. Dois dos periféricos de certo modo intervencionados - Irlanda e Espanha - tinham níveis de dívida face ao PIB - 43\% e 39\%, respetivamente - claramente dentro dos parâmetros prescritos no PaEC, ao contrário do valor médio na altura verificado na zona euro (69\%) e na própria Alemanha $(65 \%)^{4}$. Este facto, só por si, põe em causa a tese de que a origem dessa hecatombe financeira tenha sido o excesso de endividamento público, ignorando que essencialmente se tratou de um desmoronamento do sistema financeiro por erros crónicos de gestão estratégica e operacional, em especial na avaliação do risco de mútuo e de investimento ${ }^{5}$. Na verdade, uma boa parte da dívida pública hoje existente em países desenvol-

\footnotetext{
2 José Torres, Não Temos de Ser Alemães, Editora Matéria-Prima, Lisboa, 2014

3 Bank for International Settlements, 2015.

4 A qual está desde 2002 acima do teto dos 60\% / PIB.

5 Que originou igualmente um excessivo endividamento privado, empresas e famílias.
} 
vidos resulta diretamente do efeito de contaminação de dívida privada tóxica, nomeadamente com origem na banca ${ }^{6}$. De acordo com os dados mais recentes do Eurostat ${ }^{7}$, Portugal foi um dos países europeus que mais gastou com apoios ao setor financeiro entre 2008 e 2016, totalizando 12,9 mil milhões de euros (7\% do PIB), só tendo sido ultrapassado pela Irlanda (17,6\% do PIB), Grécia (15,6\%), Eslovénia (13,5\%) e Chipre (10,7\%).

O Estado português tinha à data um nível de dívida aceitável, na ordem dos $72 \%$ do PIB. No entanto, há que ter em atenção vários aspetos importantes: em primeiro lugar, existia muita dívida pública indevidamente fora do perímetro orçamental, nomeadamente do setor público empresarial, que teve de ser incorporada em nome de princípios de universalidade, credibilidade e uniformidade contabilística, impostos pela União Europeia (UE); em segundo, como bem refere Fernando Alexandre e outros ${ }^{8}$, numa análise dinâmica, a dívida pública portuguesa foi a que mais cresceu na UE em termos de percentagem do PIB desde a criação do euro até 2007 (exatamente 17 pontos percentuais). Se compararmos os últimos 20 anos (1995-2015), verificamos que a dívida pública portuguesa face ao PIB subiu 70,7 p.p., só sendo ultrapassada na UE pela Grécia (80,6 p.p.) $)^{9}$; por último, a evolução da riqueza produzida em Portugal, a roçar a mediocridade desde a entrada no euro, agravou as dúvidas, mesmo que meramente percetivas, da solvabilidade do Estado face a este galopante ritmo de endividamento.

Claro que depois havia outro fator crucial em Portugal, para muitos o mais importante. É que os agentes económicos em geral - empresas e famílias -, beneficiando das taxas de juro historicamente baixas e da liquidez promovida por uma globalização acima de tudo financeira, aumentaram os seus níveis de endividamento ${ }^{10}$. Pode inclusivamente falar-se de um certo aproveitamento político deste novo facilitismo financeiro, já que foram inúmeros os incentivos explícitos ou implícitos a tal, com o beneplácito governamental, como que a contrabalançar uma economia cronicamente de baixos salários. Muitos especialistas defendem mesmo que a explosão do endividamento privado antecede geralmente crises graves do ponto de vista macroeconómico, de que é exemplo o Japão, os próprios EUA e, vaticinam, a China a médio prazo. Aliás, o ainda hoje elevadíssimo nível de endividamento das empresas portuguesas, em especial de origem bancária, muito superior à média europeia e dos EUA, começa a assumir-se como o principal óbice ao recrudescimento consistente do investimento privado.

6 O facto de a dívida privada ser superior à pública mesmo depois de transferência de parte daquela para esta, não é exclusivo nacional nem sequer europeu. De acordo com um estudo recente do FMI, - Debt: Use it Wisely, Fiscal Monitor, October 2016 - o setor não financeiro mundial apresenta hoje uma dívida total de $225 \%$ do PIB, sendo que apenas um terço é dívida pública.

7 Disponível em «http://ec.europa.eu/eurostat/publications/statistical-reports».

8 Fernando Alexandre, Luis Aguiar-Conraria e Pedro Bação, Crise e Castigo, FMS, Lisboa, 2016.

9 Em boa parte, como referimos atrás, por efeito do forte apoio ao setor financeiro, em especial os bancos BPN, BES e BANIF, obviamente financiado por dívida pública.

10 De acordo com o boletim estatístico do BdP (fev2016), em 2015 o endividamento privado atingiu 225,1\% do PIB. 
Basicamente, podemos dizer que a dívida pública é mitigada através de:

1) Crescimento económico, gerando receitas fiscais adicionais que podem ser aplicadas no abatimento do stock nominal de dívida"

2) Inflação, que provoca a sua redução em termos reais;

3) Austeridade, com o objetivo de gerar excedentes e/ou sustar novos défices orçamentais;

4) Venda de ativos públicos, nomeadamente a privatização de empresas do SPE e alienação de património ${ }^{12}$.

A Inglaterra pôde em tempos experimentar a força do tão almejado crescimento económico no abatimento da dívida pública. No início do século XIX, a dívida pública britânica quase chegou aos $250 \%$ do PIB, na sequência de sucessivas guerras contra velhos inimigos, como a França e a Espanha, com o serviço da dívida a representar mais de $40 \%$ da despesa total durante as décadas seguintes. Beneficiando de um forte dinamismo económico, em especial alicerçado nas «Revoluções Industriais», que chegou a aumentar a riqueza per capita em 500\%, em pouco mais de 40 anos baixou o nível de dívida em quase 160 pontos percentuais, uma recuperação astronómica e dificilmente repetível em condições normais.

Mas o crescimento económico não é fácil de alcançar em economias já amadurecidas, para mais com os setores público e, em especial, privado altamente endividados. Basta ver o tempo que Portugal precisaria para garantir o parâmetro consignado no PaEC dos $60 \%$ de dívida pública relativamente ao PIB a partir do valor atual (a rondar os 130\%), mesmo que crescesse a uma taxa hoje mirífica de $3 \%$ ao ano, sem agravamento daquele stock ${ }^{13} \mathrm{e}$ «prescindindo» do efeito inflacionista: cerca de 26 anos!14 Por outro lado, sendo o crescimento catapultado também pelo aumento da população e respetiva produtividade, o certo é que, também neste domínio, o nosso país está em desvantagem, já que a sua população residente é hoje sensivelmente a mesma do que há 15 anos atrás, com a agravante de estar cada vez mais envelhecida ${ }^{15}$.

A França, como outros países europeus, beneficiou largamente de uma inflação elevada no período belicoso de 1913-1950, que chegou a 13\% ao ano. Mantendo-se tudo o resto cons-

$11 \mathrm{Ou}$, de forma mais virtual, mas indo ao encontro da tendência hodierna, mitigando o rácio Dívida Pública / PIB pelo aumento deste último (denominador).

12 Poderíamos ainda ter introduzido um quinto fator acerrimamente defendido pelo economista francês Thomas

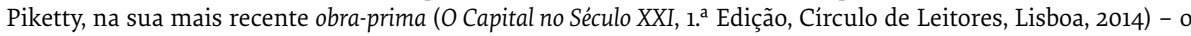
imposto progressivo sobre o capital privado, considerando-o como a solução mais justa e equitativa.

13 Ou seja, basicamente com saldos orçamentais equilibrados, o que nunca experimentámos em democracia.

14 Ricardo Cabral, economista da Universidade da Madeira, calculou que se seguissem as projeções do FMI para 2021, a dívida pública portuguesa só estará abaixo dos 60\% em 2113 (jornal Expresso, 29/10/2016).

15 Dados do INE / PORDATA. O que até pode não ser um problema, face à crescente automação da economia, que exponencia a produção por unidade de custo laboral. 
tante, uma inflação anual deste montante naquele lapso de tempo teria provocado uma redução real no stock da dívida pública para cerca de um centésimo do valor inicial, de forma relativamente indolor ${ }^{16}$ ! Também o Reino Unido conseguiu baixar a dívida pública em termos reais no pós-guerra - de $200 \%$ para 50\% do PIB já na década de 1990 - com a preciosa ajuda da inflação registada nessa altura.

A austeridade é claramente o modo mais penoso de mitigar a dívida pública, não sendo a própria eficácia isenta de críticas nos meios académicos. O princípio em que se baseia é idêntico, a contrario, ao visado com o crescimento económico: obtenção de saldos orçamentais excedentários através do aumento da receita e, em especial, da redução da despesa pública, de forma a diminuir as necessidades de financiamento futuras e abater ao stock da dívida soberana. Na teoria funciona bem, o problema é que a realidade teima em contrariá-lo. Os portugueses sabem-no bem.

Existem dois grandes efeitos colaterais que não podem ser ignorados: por um lado, redução da despesa pública, que, para além do investimento público, acaba por recair em geral na vertente social (o chamado «Estado Social»), nomeadamente na saúde, educação e no apoio aos infortunados e carenciados, diminuindo amplamente a qualidade de vida dos cidadãos e a perceção da justeza da carga fiscal a que todos são submetidos; pelo outro, redução do rendimento disponível dos particulares por via do aumento de impostos, da mitigação da despesa fiscal e do abrandamento das transferências sociais, levando a uma menor propensão ao consumo e, deste modo, a uma espécie de círculo vicioso - medidas austeritárias, menos rendimento disponível, menos procura, investimento e crescimento, menos receitas fiscais, menos rendimento disponível, novas medidas austeritárias.

Aliás, tudo isto acabou por ser recentemente reconhecido pelo FMI numa espécie de mea culpa, na sequência das duras experimentações elevadas a cabo nos países periféricos da europa, no âmbito do seu vasto programa de austeridade ${ }^{17}$. Nada de admirar, se pensarmos bem: Portugal tem hoje um stock total de dívida pública na ordem dos 245 milhões de euros. Ora, contar primordialmente com excedentes orçamentais - realidade absolutamente desconhecida no país na era democrática - para amortizar esse volume de dívida é de facto um exercício situado no plano do imaginário.

Finalmente, temos a questão da venda de ativos públicos. Antes de mais, devemos ter em conta que o conceito de dívida pública bruta é aquele que, bem ou mal, é utilizado para efeitos de contabilidade nacional. Não deixa de ser uma forma algo enviesada de olhar para a susten-

16 Isto, claro, ignorando os efeitos perniciosos da inflação na vida socioeconómica de qualquer país.

17 Referimo-nos à subestimação dos efeitos recessivos na economia provenientes das medidas de austeridade, de acordo com um relatório do Gabinete de Avaliação Independente do FMI, publicado em 28/07/2016, com o título The IMF and the Crises in Greece, Ireland, and Portugal. 
tabilidade financeira de um Estado, já que apenas atende aos passivos, ignorando os ativos. A verdadeira situação patrimonial e financeira de uma entidade contabilística, seja a que escala for, apura-se confrontando a totalidade dos passivos com os seus ativos, não sendo raro que, por exemplo, grandes e prósperas empresas detenham um passivo de grandes dimensões. Tal representa só um lado da realidade. De acordo com alguns autores, a dimensão da totalidade dos ativos públicos de um país ocidental, neles se incluindo infraestruturas, aplicações financeiras, reservas de ouro, etc., será grosso modo idêntica à da dívida pública bruta.

Fruto de uma herança fortemente estatizante, em que tudo girava e encontrava suporte num Estado paternalista, Portugal tem ainda hoje um amplo leque de ativos do domínio público, apesar da recente privatização de algumas das suas lucrativas empresas, que funcionavam como autênticas «vacas leiteiras», na conhecida expressão comercial. Por outro lado, de acordo com os dados do World Gold Council, Portugal terá uma das maiores reservas de ouro do mundo em termos absolutos, com cerca de 380 toneladas, correspondendo, a preços de mercado, a quase $10 \%$ do seu PIB, o maior peso relativo entre os países desenvolvidos. Sendo a sustentabilidade da dívida pública apurada, a nosso ver, pela probabilidade real (elemento objetivo) ou percecionada (elemento subjetivo) de os credores reaverem a totalidade do capital investido e correspondentes juros, este panorama dá alguma tranquilidade. Foi nesta senda que, há tempos, um alto responsável alemão afirmou, de forma algo sobranceira, que se a situação persistisse em correr mal e a Grécia tivesse dificuldades em pagar as suas dívidas poderia sempre alienar umas ilhas, o que foi muito mal interpretado. Mas é objetivamente correto pensá-lo.

$\mathrm{Na}$ impossibilidade de se socorrer do crescimento económico e da inflação para reduzir o peso da dívida soberana, o Estado português foi até há pouco tempo empurrado pelas elites europeias e mundiais para a adoção de políticas de austeridade e para a alienação de empresas públicas, algumas em regime de monopólio natural e bastante lucrativas. E as coisas não correram bem. A austeridade provocou forte contração económica, perda de rendimento e de qualidade de vida entre os portugueses e, não obstante, aumento da dívida pública. Ao mesmo tempo, as privatizações feitas em condições difíceis e de modo algo apressado, na ausência de liquidez interna, levaram à redução patrimonial do Estado com a perda dos ativos e à degradação da sua situação financeira (receitas de capital) pela perda dos dividendos. E o pior de tudo é que a redução do stock de dívida com essa alienação de ativos foi pouco mais do que irrelevante, sendo que os dividendos que se deixaram de ganhar nem sequer compensaram a diminuição dos encargos com a dívida pública decorrentes do correspondente abatimento ${ }^{18}$.

18 O caso dos CTT é sintomático: calcula-se que valesse entre 600 e 700 milhões de euros em 2013, mas só de lucro rendeu no primeiro semestre desse ano 37 milhões. Ora, tendo em conta a atual taxa de juro implícita da dívida soberana nacional, diríamos que não foi um grande negócio: o que se vai deixar de pagar em serviço da 
Isto sem falar nos efeitos geopolíticos e geoeconómicos decorrentes da abdicação de algumas das chamadas empresas-bandeira ${ }^{19}$, ao prejudicar a capacidade de orientação estratégica em direção a desígnios soberanos, ficando igualmente os agentes económicos vulneráveis a padrões de preço e qualidade que o Estado não consegue controlar, por mais cuidadosos que tenham sido os contratos de privatização. Ainda está por comprovar, unicamente no plano económico, a vantagem de ter uma empresa privada ao invés de uma pública num setor não concorrencial, em especial quando revestir interesse estratégico nacional ${ }^{20}$. Isto numa altura em que se reconhece de forma inequívoca a necessidade de definir claramente uma estratégica nacional e de cimentar os vetores do investimento e das exportações ${ }^{21}$.

Reparemos agora na evolução da dívida pública (bruta), PIB e IPC em Portugal desde 1991:

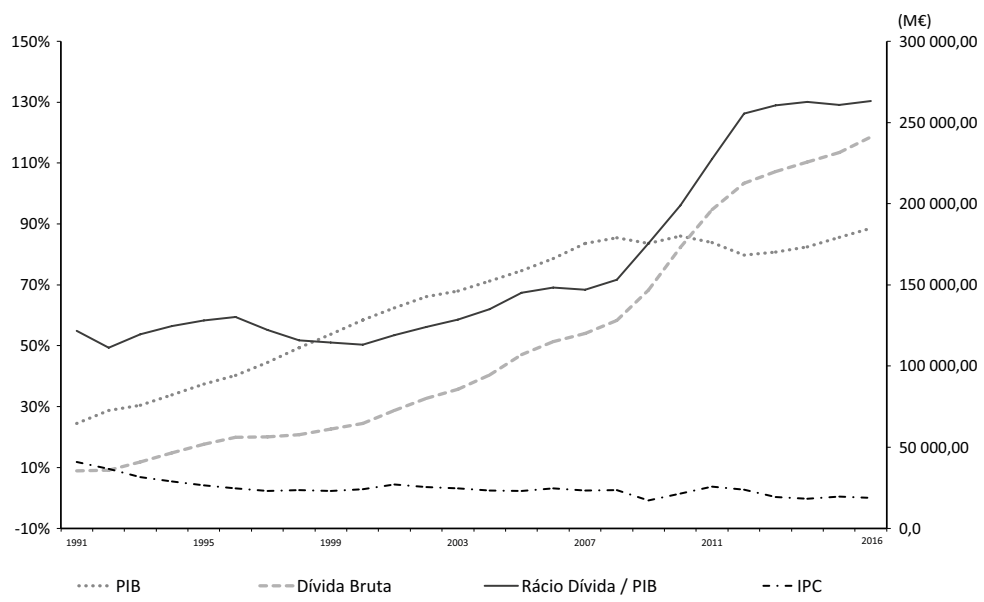

Fig. 1: Evolução da dívida pública, PIB e IPC em Portugal

(Fonte: Elaboração própria, com base nos dados primários da PORDATA)

dívida pelo abatimento daquele montante é sensivelmente igual aos dividendos potenciais em quatro meses. $\mathrm{O}$ abatimento da receita da venda do ativo, à volta dos cinco mil milhões de euros, acabou obviamente por se diluir nesse imenso «mar» que é o stock da dívida pública portuguesa.

19 Empresas estratégicas e simbólicas que projetam influência nacional e atuam alinhadas com as grandes orientações políticas e económicas do governo, como a TAP e, até há pouco, ANA e os CTT.

20 Talvez seja bom lembrar que grandes empresas, agora total ou parcialmente privatizadas, como a antiga PT, Galp, EDP, CTT, CIMPOR, ANA, REN, entre muitas outras, cresceram e consolidaram posições no setor público empresarial, tendo desenvolvido vasto e complexo know-how e adquirido uma dimensão e massa crítica que ainda hoje lhes conferem grandes vantagens competitivas neste mundo global.

21 De acordo com dados recentes divulgados na edição do jornal Expresso de 05/11/2016, 48\% do grupo das 500 maiores \&melhores empresas de Portugal é controlado por capital estrangeiro, contra $43 \%$ de capital privado nacional, $7 \%$ público e os restantes $2 \%$ cooperativo. 
De acordo com o mesmo, o rácio da dívida pública face ao PIB manteve-se a níveis estabilizados até 2001, altura em que começa a agravar-se de forma gradual por um duplo-efeito: por um lado, o stock da dívida retoma uma tendência de forte crescimento, evidenciado por uma curva de formato côncavo, em que as taxas de crescimento são marginalmente crescentes e, pelo outro, no que toca ao PIB, verifica-se uma quebra de uma linha evolutiva de formato côncavo para convexo sensivelmente a partir desse mesmo ano. O efeito combinado resultou no disparo da dívida portuguesa em percentagem do PIB, embora se tenha mantido dentro dos níveis do PaEC até meados de 2004, sendo que até finais de 2008 foi inferior a 70\%, como vimos atrás. Por outro lado, a inflação mostrou de forma continuada uma estabilização marcadamente decrescente, situando-se atualmente em valores residuais próximos do zero, provocando um contínuo aumento real do stock da dívida pública.

Em 2016 terá atingido $130,4 \%^{22}$, ultrapassando sucessivas «barreiras de sustentabilidade», se bem que esta, como já referimos atrás, mais do que um valor concreto, se traduza quanto a nós numa espécie de teto imaginário estabelecido casuisticamente em função do grau de confiança e das expetativas dos credores na sua solvabilidade ${ }^{23}$. No entanto, em abono da verdade, é preciso dizer que até 2001 a variação média do stock da dívida foi de 19\% ao ano (mas genericamente decrescente ao longo dos tempos, depois dos «anos loucos» da década de 80), sendo que desde aquela data até 2013 baixa para 10\% / ano, mesmo influenciada pelos anos pós-crise financeira.

Seja como for, o volume de dívida pública, numa conjuntura de baixo crescimento e inflação como a atual, não deixa de ser preocupante. Para além disso, há ainda que ter em conta o stock de dívida que recai sobre entidades públicas fora do perímetro orçamental, nomeadamente do setor empresarial, o qual, apesar de não ser estatisticamente considerado nas contas de Bruxelas, pode vir a sê-lo por motivos diversos, apenas por mera decisão administrativa, como aconteceu num passado recente. Mas, mesmo que o não seja, não deixa de ser dívida pública, em bom rigor. E, segundo as contas do Banco de Portugal (BdP) e IGCP, falamos de mais de 33 pontos percentuais do PIB!

Como já referimos, Portugal teve uma trajetória de permanente agravamento da dívida pública desde há 20 anos, com especial enfase após a entrada na zona euro, como bem ilustra a fig. 2. Por exemplo, em relação à Itália, o nosso país começa com um peso de endividamento público bem inferior, acabando por estar praticamente ao seu nível em 2015. Não podemos ficar indiferentes a situações como a da Bélgica e principalmente da Suécia, que,

22 Dados da PORDATA, ainda não consolidados.

23 Entendida aqui como probabilidade das atuais e futuras dívidas contraídas serem integralmente pagas, juntamente com os respetivos juros e demais encargos. 
em claro contraciclo com a generalidade dos países escrutinados, conseguiram baixar o rácio de dívida pública face a 1995, aparentemente demonstrando elevado critério e ponderação na gestão das contas públicas. Aliás, parece ser uma questão cultural comungada de uma maneira ou de outra pelos restantes países do norte da Europa.

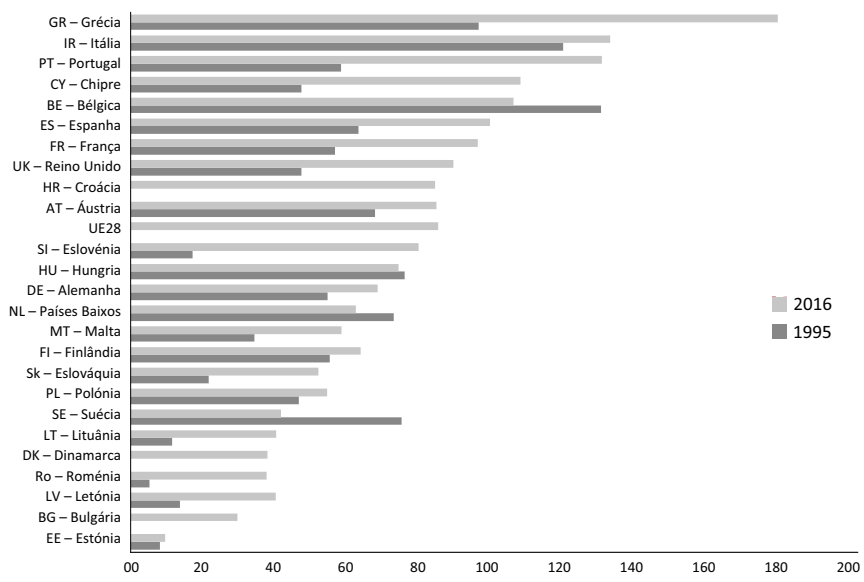

Fig. 2: Evolução da dívida pública nos países da UE desde 1995

(Fonte: Elaboração própria, com base nos dados primários da PORDATA)

Mas existe um prisma de análise que raramenteéconsiderado nos meios académicos enos media especializados, que não tem relação com a dívida pública bruta face à riqueza nacional produzida num ano (PIB) mas sim comparando-a com a população residente. Esta medida, grosso modo, traduz o peso potencial de impostos que pode futuramente recair sobre cada cidadão, se não se contar com outras «muletas» já faladas anteriormente, como a inflação e crescimento económico. Atentemos então no gráfico seguinte, contendo dados relativos a 2014.

Como podemos verificar, sob este prisma, Portugal não é dos países que «oferecem» aos seus cidadãos um maior peso de dívida pública. Está abaixo de países de referência da economia mundial, como por exemplo o inevitável Japão, os EUA, Canadá, Reino Unido, Holanda e Noruega. Há que reconhecer que a realidade pode ser uma, mas tem sempre várias formas possíveis de ser lida e interpretada.

Para além disso, nem sempre a contração de dívida pública é uma decisão genericamente adversa para os cidadãos. Pode até ser a mais justa e acertada, mesmo quando os fundos disponíveis no momento a dispensassem. Na verdade, ela pode ser aconselhável por razões de equidade intergeracional (distribuir custos de investimento por diferentes gerações de contribuintes), para antecipar investimentos necessários para o desenvolvimento 


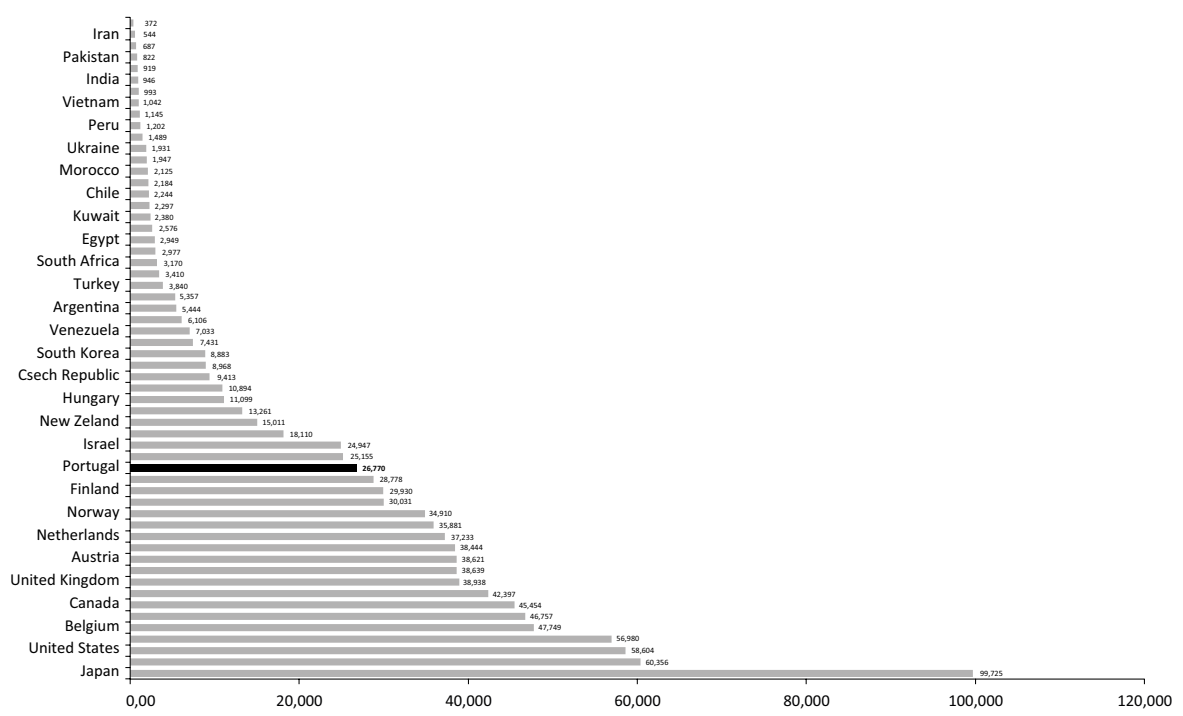

Fig. 3: Comparação da dívida soberana per capita entre países

(Fonte: Elaboração própria, com base nos dados primários Bloomberg Visual Data - 2015)

e bem-estar social da comunidade (evitando o correspondente «custo de oportunidade» de não os fazer), para financiar uma reestruturação orgânica e funcional do Estado, tornando-o mais eficaz e eficiente, bem como para acorrer a catástrofes naturais e guerras, entre muito outros. Não é necessariamente sinónimo de «vida fácil».

\section{As várias nuances do endividamento público}

Independentemente das visões que se tenha sobre o endividamento, numa coisa existe unanimidade: quanto menor o volume de dívida, melhor. Na aparência e, em grande medida, na realidade, a dívida soberana é o problema central do foro orçamental de Portugal. Mas veremos também que não é só nem tanto o volume, mas a natureza e qualidade da dívida que importa atender em especial.

A questão da sustentabilidade da dívida pública é das mais repisadas e debatidas de todo o espetro da ciência económica. Não faltam opiniões e até cálculos para tal, que sucessivamente se vieram a demonstrar pouco sustentados ${ }^{24}$. O limite protagonizado no

24 Recorde-se que uma das mais mediatizadas tentativas de chegar a um número de sustentabilidade da dívida soberana foi protagonizada por dois experientes economistas de Harvard, Carmen Reinhart e Kenneth Rogoff, que chegaram a «demonstrar» que uma dívida pública superior a 90\% seria um óbice ao crescimento económico. 
PAeC (60\% do PIB) não pode servir de referência sólida, já que ainda carece de explicação científica credível $^{25}$. Vimos já que essencialmente o crescimento económico e a inflação podem resolver, de forma ativa ou passiva, dívidas soberanas aparentemente insanáveis. Mesmo quando tal não acontece, existe sempre a hipótese extrema de reestruturação da dívida, incluindo os famosos «haircuts», como aconteceu com a austera Alemanha, durante a letargia económica em que mergulhou em 1953, beneficiando de um perdão parcial da dívida do pós-guerra, num montante equivalente a metade do stock, bem como uma redução da taxa de juro e um reescalonamento do plano de pagamento. Só assim conseguiu passar de quase $700 \%$ de endividamento público face ao PIB no início da 2. ${ }^{a}$ Grande Guerra para menos de $20 \%$ na década de 1970, ganhando balanço para épocas de maior prosperidade.

Não obstante todas estas considerações, como, de resto, em muitas áreas da economia e finanças públicas, a sustentabilidade da dívida soberana, assenta num jogo de confiança, no qual o credor exige um prémio de risco superior quando esse sentimento baixa em relação ao devedor, sentimento esse não raras vezes de base eminentemente subjetiva ${ }^{26}$.

A dívida portuguesa tem uma particularidade muito importante e que, estranhamente, tem sido obnubilada pelos especialistas na matéria - a sua natureza genética -, o que nos leva para os conceitos de divida virtuosa, viciosa e duplamente viciosa ${ }^{27}$. Todos sabemos que, mesmo a nível doméstico, nem toda a dívida é igual. Na verdade, uma coisa é uma família endividar-se para investir em habitação ou num terreno para construção ou exploração agrícola, outra é para adquirir o último modelo daquela marca de automóveis de sonho, viagens ou roupa. No primeiro caso, estamos a falar de dívida para investimento, esperando-se que o bem em causa possa vir a gerar retorno económico, quiçá a reproduzir riqueza (dívida virtuosa), enquanto que, neste último, trata-se de endividamento para trazer bem-estar efémero, consumível a curto-prazo sem caráter reprodutivo (dívida viciosa).

Mas pior é contrair dívidas para pagar juros de dívida antiga, situação que, gerando um efeito bola de neve, e se não ocorrer um choque orçamental de qualquer espécie que

No entanto, foram contundente e algo embaraçosamente confrontados com erros de metodologia e de análise por um grupo de jovens economistas da Universidade de Massachusetts Amherst. Uma das críticas refere-se à subestimação da influência da dívida privada na evolução da economia e até da própria dívida pública (efeito transferência dívida privada - dívida pública).

25 No fundo, um valor alinhado com o dos países precursores do Euro - França e Alemanha - à data das conversações que deram origem ao Tratado de Maastricht, evidenciando uma visão umbilical das regras a impor aos restantes.

26 Embora as agências de rating desempenhem um papel facilitador neste capítulo, ao disponibilizar aos seus clientes análises supostamente objetivas versando a capacidade de solvência das diversas entidades.

27 Vide, a este propósito, José Torres, op. citada. 
mude esse estado de coisas, inevitavelmente irá acarretar a insolvência familiar, já que esta não consegue gerar superavits orçamentais estruturalmente compatíveis com as suas necessidades de financiamento. Aqui estamos perante uma dívida duplamente viciosa.

No plano macro, a dívida pública torna-se virtuosa quando é utilizada de modo inequívoco para o progresso socioeconómico de um país, nomeadamente para ajudar a cobrir o défice do saldo de capital, em especial quando gerado por investimentos reprodutivos. Mas é à partida viciosa se se destinar a cobrir défices orçamentais correntes, já que aqui apenas se estará a adiar (e a agravar) o problema. Contudo, é preciso dizer que a grande parte da despesa primária do Estado (ou seja, com exclusão dos juros da dívida), seja de pessoal, consumos intermédios e até a de cariz transferencial (como por exemplo as prestações sociais) não são improdutivas, pois destinam-se em última instância, a produzir bem-estar para as populações. Assim é, só a título de exemplo, quando se paga salários de médicos e professores, o consumo de combustível para o patrulhamento policial das ruas ou simplesmente o subsídio de desemprego a um cidadão. O problema é ter que contrair dívida de médio/ longo prazo para o fazer, o que faz emergir um desequilíbrio temporal entre a origem e a aplicação do capital.

Torna-se mais grave ainda quando a dívida é aplicada, mesmo que de forma parcial, no pagamento de encargos com dívida antiga, inclusive em processo de renovação, o que acaba por ser uma derivação dos conhecidos jogos de Ponzi $i^{28}$. No fundo, representa a sua eternização - uma espécie de dívida autofágica, que é contraída para pagar os encargos com a anterior, tornando-se cada vez mais volumosa, inerte e naturalmente impagável. Nestes casos a dívida é duplamente viciosa, fazendo normalmente antever o caos financeiro.

Se fizermos um estudo de correlação estatística, verificaremos que $99 \%$ da dívida do Estado português tem estado diretamente ligado à evolução da despesa corrente, incluindo o pagamento de juros de dívida antiga, sendo aquela a grande responsável pela derrocada das contas públicas e em parte pelo mergulho económico português. Reparemos no gráfico seguinte:

28 O termo Jogo de Ponzi é inspirado no esquema dos anos 20 do século XX da autoria de Charles Ponzi, consistindo numa operação fraudulenta de investimento do tipo esquema em pirâmide que envolve o pagamento de rendimentos anormalmente altos aos investidores atuais à custa do dinheiro pago pelos que chegarem posteriormente. Aparentemente, o Estado pode desenvolver uma operação do tipo «jogo lícito de Ponzi», ao emitir nova dívida para pagar dívida vencida. No entanto, teoricamente, tal só é viável quando a taxa de crescimento real da economia é superior à taxa de juro real da dívida soberana. 


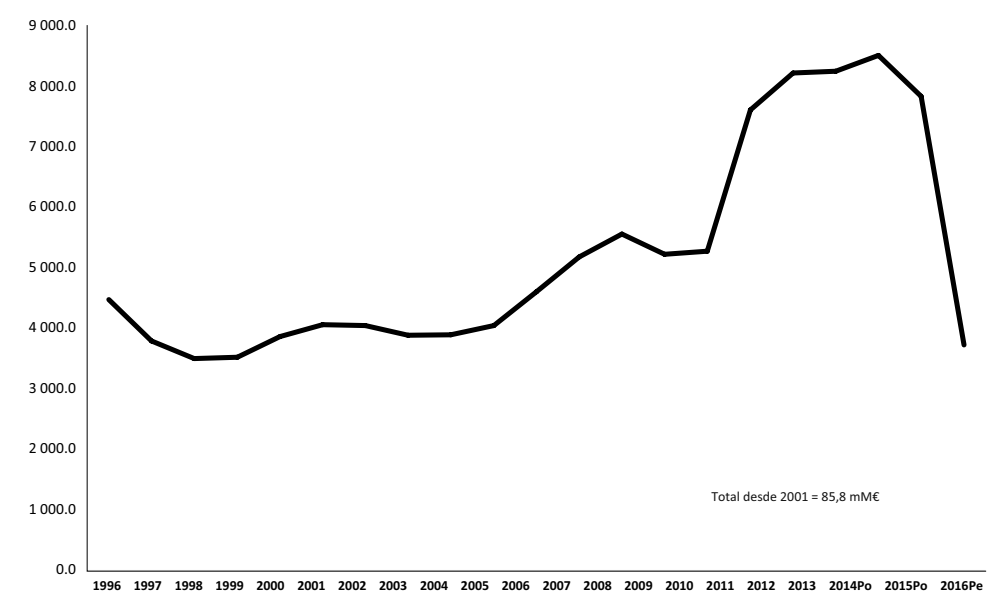

Fig. 4: Volume de dívida pública assumida diretamente para pagar juros de dívida pública portuguesa (Fonte: Elaboração própria)

Conforme decorre da sua leitura, desde a entrada na zona euro Portugal contraiu cerca de 85,8 mil milhões de euros de dívida soberana exclusivamente para pagar os encargos com dívida antiga, o que representa $36 \%$ do stock de dívida registado em $2016^{29}$. Este valor astronómico, que decorre da geração de saldos primários sem capacidade de cobertura das despesas com juros ${ }^{30}$, correspondendo a três orçamentos de saúde e educação juntos, expõe o país a uma elevada vulnerabilidade a choques externos com origem no mercado de financiamento público, o qual se tem revelado extremamente nervoso, volátil e desconfiado, em especial no que concerne à dinâmica da nossa dívida pública e aos fundamentais macroeconómicos, em geral.

Deste modo, se atentarmos no quadro seguinte, verificamos que, de facto, tem sido em especial o efeito da acumulação de juros pagos aos credores o fator primordial de agravamento do rácio da dívida pública face à riqueza produzida pelo país, revelando uma preocupante consistência nessa pesada fatura orçamental.

29 O agravamento sensível dos pagamentos de encargos com a dívida soberana a partir de 2010 reflete a dificuldade de financiamento do Estado na sequência da crise de 2008, que fez disparar a taxa de juro da dívida soberana. O apoio da «troika» - Comissão Europeia, BCE e FMI - nessa altura crítica da nossa história económica recente, apesar dos méritos reconhecidos, não primou por ser especialmente generosa nesse capítulo, já que a taxa de juro implícita rondou os 3,6\%, muito acima dos custos financeiros que a mesma, por sua vez, assumiu junto dos credores.

30 Aliás, muito deles já de si deficitários. 
Desafiar Mamon: O Estado das Contas Públicas

JOSÉ EMANUEL MATOS TORRES

\begin{tabular}{lccccccc}
\hline & 2010 & 2011 & 2012 & 2013 & 2014 & 2015 & 2016 \\
\hline 1. Stock da dívida bruta (final do período) & 96,2 & 111,4 & 126,2 & 129,0 & 130,6 & 129,0 & 130,4 \\
\hline 2. Variação da dívida (p. p. do PIB) & 12,6 & 15,2 & 14,8 & 2,8 & 1,6 & $-1,6$ & 1,4 \\
\hline 3. Efeito dinâmico & 0,8 & 6,4 & 10,0 & 3,5 & 2,8 & $-0,1$ & 0,5 \\
\hline Efeito juros & 2,9 & 4,3 & 4,9 & 4,9 & 4,9 & 4,6 & 4,2 \\
\hline Efeito do crescimento nominal do PIB & $-2,1$ & 2,1 & 5,1 & $-1,4$ & $-2,1$ & $-4,7$ & $-3,8$ \\
\hline 4. Efeito do Saldo Primário & 8,2 & 3,1 & 0,8 & 0,0 & 2,3 & $-0,2$ & $-2,2$ \\
\hline 5. Outros & 3,5 & 5,8 & 4,0 & $-0,6$ & $-3,5$ & $-1,3$ & 3,1 \\
\hline
\end{tabular}

Fig. 5: Dinâmica da dívida pública portuguesa

(Fonte: Elaboração própria, com base nos dados primários do MF)

O peso dos juros faz-se sentir cada vez mais nos orçamentos nacionais, pressionando contínua e crescentemente a despesa corrente, a qual continua a suplantar a receita homóloga (corrente), criando défices indutores de dívida viciosa e duplamente viciosa, como vimos. Este é um dos desafios atuais da gestão das contas públicas da atualidade, já que nos mais de 40 anos de democracia raramente cumprimos a regra considerada por Keynes como a pedra angular neste domínio: existência de superavits correntes para financiar os défices virtuosos do saldo de capital ou, não sendo isso possível, emissão controlada de dívida para esse efeito. No meio deste nevoeiro ideológico, nada como rebuscar os clássicos.

Repare-se no gráfico seguinte:

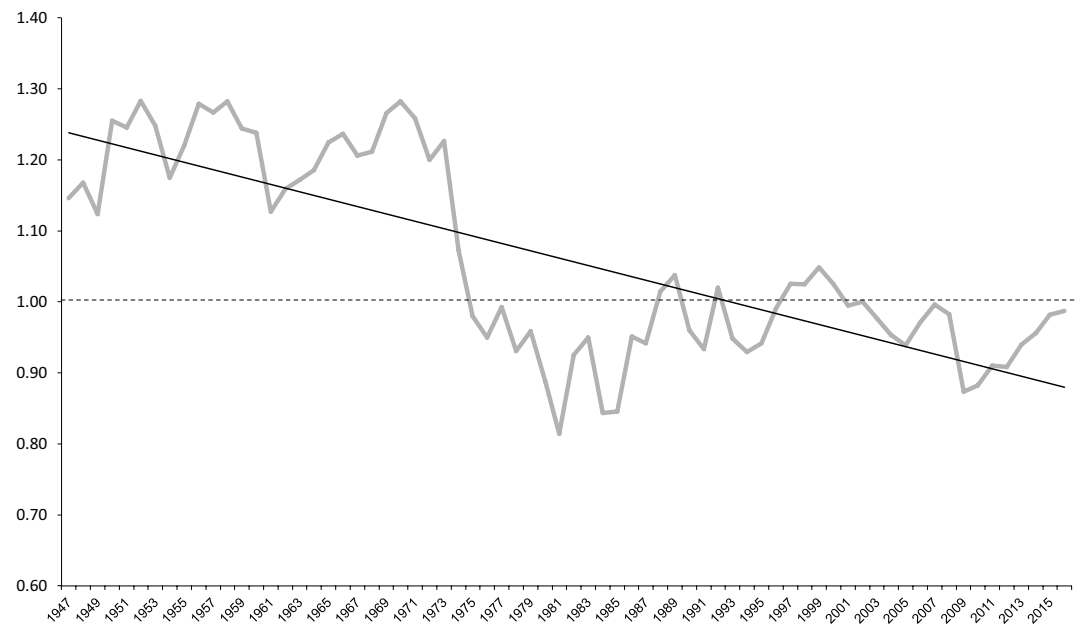

Fig. 6: Evolução do grau de cobertura das despesas correntes pelas receitas correntes 
Como se pode verificar, depois de uma "época dourada" no que toca à observância da regra de ouro keynesiana que coincidiu com a ditadura de Salazar ${ }^{31}$, na era democrática rareiam as situações de controlo do défice corrente, levando à contração permanente de dívida viciosa, quando não duplamente viciosa. Aliás, foi precisamente durante o período em que Portugal recebe assistência financeira externa (1979, 1983 e 2011) onde o défice corrente se revelou mais descontrolado, o que indicia a importância efetiva desse exercício de rigor orçamental.

A realidade mais recente, apesar de ainda insatisfatória neste domínio, apresenta tendência de melhoria, embora, há que dizê-lo, se levantem algumas dúvidas sobre a sua sustentabilidade, tais as fontes de pressão existentes. E entre elas estão os juros da dívida pública, pese embora o esforço de reestruturação da dívida levados eficazmente pelo IGCP, substituindo dívida mais cara por outra mais suave e preferencialmente com períodos mais longos, aproveitando uma conjuntura favorável para tal - muito por mérito do BCE -, de forma a aliviar as necessidades futuras de financiamento. Para além disso, há que esperar para ver os efeitos da reversão de algumas das últimas medidas conjunturais de pura austeridade, como o descongelamento das progressões na Administração Pública e a abolição total da sobretaxa de IRS.

Mas existem outros, de teor mais estrutural, em sede de despesa corrente primária, como os encargos crescentes das pensões face ao envelhecimento populacional - uma autêntica «bomba relógio orçamental» -, obrigando, mais tarde ou mais cedo, a tributar de forma mais agressiva as pensões em pagamento mais elevadas, a par das alterações de cariz restritivo no regime de aposentação dos atuais contribuintes, que têm vindo a ser sucessivamente implementadas. Também a questão dos gastos tendencialmente crescentes na saúde, fruto do avanço tecnológico, do aumento da esperança de vida e da atividade permanente de lobbying das grandes empresas do setor impõem desafios aos Governos democráticos, nomeadamente no plano ético-moral ${ }^{32}$. Por último, claro, a eternamente adiada reestruturação orgânico-funcional do Estado, no sentido de uma racionalização vertical e horizontal (fusão, «downgrading» e «downsizing»), talvez a forma mais eficaz e efetiva de reduzir a despesa corrente primária, bem como a que, teoricamente, apresentará menor potencial de nocividade para a Economia e de convulsão social.

31 Embora existam fundadas dúvidas quanto ao rigor e fidelidade das contas públicas dessa longa noite da História de Portugal. Mas, seja como for, um exercício de boa contabilidade não significa idêntico sucesso na governação, mesmo no plano económico. Na verdade, o custo de oportunidade dessa opção cega pelo rigor ortodoxo do controlo dos défices e da dívida, mesmo com espaço de endividamento, foi bem sentido pela generalidade dos portugueses, ao nível da pobreza e do acesso à educação, saúde e cultura.

32 Onde talvez a discussão mais sensível passe pela gestão adequada do eterno equilíbrio entre o prolongamento da vida em doentes com baixa esperança de vida e o investimento em profilaxia. Ou até onde deve ir o esforço na deteção precoce de possíveis - mesmo que pouco prováveis - doenças graves num futuro mais ou menos distante da vida de cada ser humano. 
Ora, com todo este incontido avolumar de dívida pública geneticamente viciosa, não se repercutindo em investimento público reprodutivo que gere crescimento económico, e sem a «boleia» da inflação, abre-se de facto espaço, mais tarde ou mais cedo, a novas políticas tendencialmente austeritárias, não tanto para mitigar o seu stock de forma direta - os efeitos são pouco relevantes neste capítulo - mas essencialmente para tranquilizar os «mercados», sempre receosos que a situação descambe ao ponto dos seus créditos financeiros poderem vir a ser prejudicados em termos de rentabilização efetiva.

\section{A dívida pública externa}

Sabe-se que o endividamento externo, como um todo, acarreta especiais vulnerabilidades e consequências económicas e financeiras. Contudo, a questão particular da dívida pública externa, em especial quando do tipo negociável, não é menos importante.

Ao contrário da dívida interna como um todo, que não gera ónus para as gerações futuras, já que se trata apenas de um fluxo financeiro interno (o dinheiro passa de umas mãos para outras) - exceto em situações especiais e raras do ponto de vista macroeconómico em que a compra de dívida pública pela sociedade civil nacional implica a privação pela mesma de bens relevantes de consumo ${ }^{33}$-, a dívida pública externa implica forçosamente ónus para as gerações futuras, na medida em que a amortização e o serviço da dívida serão por elas também suportados, para mais com um exfluxo monetário para o exterior sob a forma de juros.

Por outro lado, existem outros aspetos não menos importantes a considerar associados à dívida soberana quando detida por entidades externas, especialmente no quadro de orientações superiores de índole geopolítica e geoeconómica. Na verdade, quando dependente do financiamento de entidades externas, qualquer país fica de algum modo subordinado às suas estratégias particulares - não raras vezes em alinhamento estreito com potências estrangeiras - e frequentemente aos seus humores e excentricidades conjunturais. A perda de controlo e de soberania é evidente ${ }^{34}$. Como disse um dia uma reputada economista e ex-governante portuguesa, «quem empresta, manda!».

Para além disso, importa ter igualmente em conta o maior ou menor grau de negociabilidade da dívida pública, ou seja, a sua composição específica - detenção de instrumentos de maior ou menor liquidez, de cariz mais conservador ou especulativo. O quadro seguinte

33 Embora agrave fenómenos de desigualdade social, já que os detentores de dívida pública são muito menos e em média mais abastados do que a generalidade dos contribuintes.

34 Como recentemente pudemos constatar com a entrada em cena da troika e, na atualidade, na relação com o BCE, um dos principais detentores de Obrigações de Tesouro nacionais. 
(fig. 7) ilustra a evolução da composição da dívida pública direta portuguesa, no que toca ao seu grau de negociabilidade.

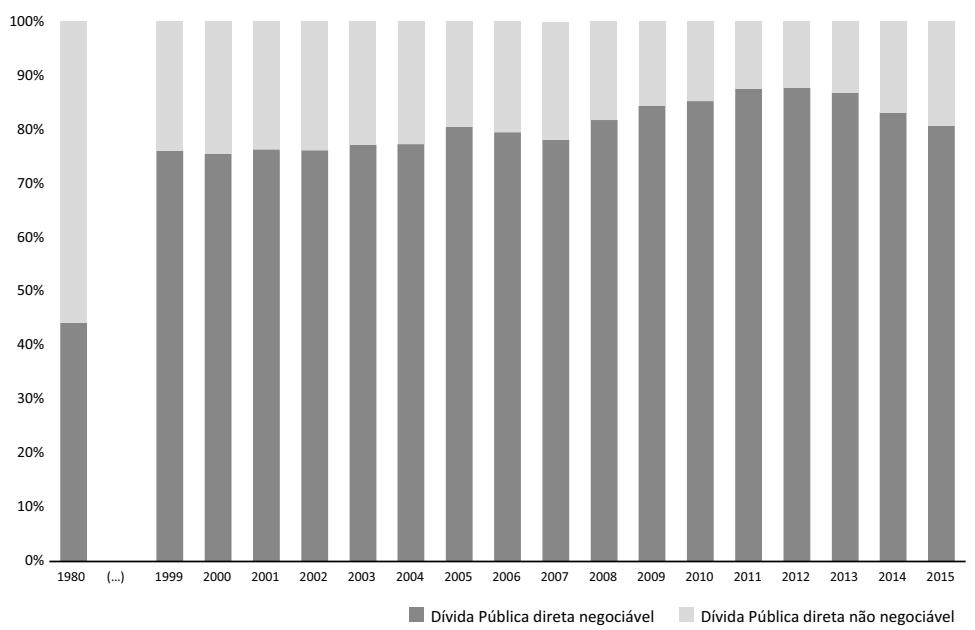

Fig. 7: Evolução da composição genérica da dívida pública nacional, excluindo o PAEF (Fonte: Elaboração própria, com base nos dados primários do IGCP)

Como se pode inferir facilmente do mesmo, desde 1980, ano que a parcela de dívida não negociável ${ }^{35}$ foi mais elevada, o peso da dívida negociável ${ }^{36}$ tem vindo a aumentar de forma sistemática até atingir em 2011 e 2012 o valor recorde de $88 \%$ do total, vindo desde então a diminuir, não tanto por opção estratégica, mas essencialmente por força da substituição das operações normais de financiamento nos mercados pelo Programa de Assistência e Estabilização Financeira (PAEF), acordado em 2011 entre o Estado português e a troika. Essa tendência tinha como efeito a crescente sujeição das necessidades de financiamento da Administração Pública aos humores e sensibilidades dos mercados financeiros e de lógicas puramente especulativas, mesmo de entidades residentes (ex: sociedades financeiras), ditados inevitavelmente pelas agências de rating. E isso normalmente não é bom. Claro que a adesão à zona euro, com a ilusão que trouxe de que as taxas de juro da dívida pública portuguesa estariam sempre ao nível das alemãs, como de resto aconteceu até 2008, esmo-

35 Dirigida a investidores particulares de perfil mais conservador, que buscam rentabilidades interessantes sem grande risco, como os Certificados de Aforro.

36 Dívida normalmente dirigida a investidores institucionais e comercializada no mercado primário, maioritariamente sob a forma de Bilhetes do Tesouro e Obrigações do Tesouro. 
receu naturalmente a prudente preocupação de lhe conferir uma estrutura mais estável e previsível, para evitar embates externos.

Mas para além desta abordagem à dívida pública, urge ainda decompô-la quanto à origem do financiamento da mesma (interna e externa) até ao ano de charneira (2011), altura em que se começa a fazer sentir a crise financeira global e em que entra em cena a troika, como decorre da fig. 8 .

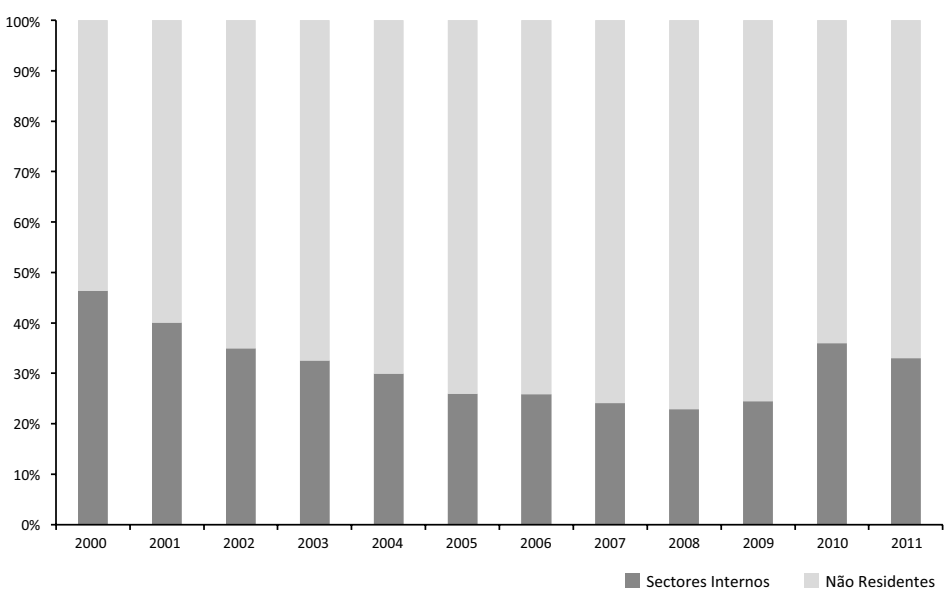

Fig. 8: Evolução da estrutura de Dívida Pública nacional segundo o tipo de detentor no período 200o-2011 (Fonte: Elaboração própria, com base nos dados primários do BdP)

Como resulta da sua leitura imediata, até 2008 a dívida pública nacional esteve de forma crescente nas mãos de entidades não residentes no país, em paralelo com a tendencial diminuição do rendimento disponível das entidades nacionais (particulares e empresas) e da liquidez das instituições financeiras que por aqui operam. A partir desse ano houve uma ligeira inversão da tendência, já que, para além da operação de financiamento da troika, os bancos nacionais aproveitaram o financiamento a baixo custo do BCE para adquirir lotes maciços de dívida pública portuguesa, o que lhes permitiu obter uma rendibilidade apreciável, embora sem dispensar um certo grau de risco ${ }^{37}$.

37 Esta atitude dos bancos portugueses, que terá sido concertada ou, pelo menos, tolerada pelas autoridades europeias, não deixa de estar sujeita a crítica, já que acabou por desviar fundos que poderiam ser úteis no financiamento de outros agentes económicos necessitados de liquidez, como as PME. 
De acordo com os dados mais recentes ${ }^{38}$, o maior credor de dívida pública portuguesa em 2015 continuam a ser entidades externas, embora com menor intensidade, com a troika à cabeça (36,7\% do total da dívida portuguesa), representando os restantes investidores não residentes $29,9 \%$. Os residentes particulares aumentaram em $28 \%$ a sua carteira de títulos de dívida pública face a 2010, maioritariamente através de Certificados de Aforro (CA) e Certificados do Tesouro (CT), representando agora 7,4\% da dívida pública portuguesa. Por outro lado, o setor financeiro residente diminuiu a sua exposição para $25 \%$, representando agora menos 4,3 p.p. do que em 2010.

É uma situação que, a manter-se em todos os seus contornos - há que ter em atenção em especial a forma de substituição da dívida à troika à medida que ela vai chegando ao fim, via efeito rolamento do stock -, pode anunciar uma tendência de maior previsibilidade e estabilidade das taxas de juro nacionais, tornando a dívida pública menos vulnerável a choques externos, ao mesmo tempo que não acarreta uma sangria tão grande de riqueza para o estrangeiro ${ }^{39}$.

A figura 9 (infra) ilustra genericamente os quatro quadrantes possíveis de posicionamento da dívida pública quanto à sua estrutura e composição - origem geográfica do financiamento e grau de negociabilidade do instrumento de dívida em concreto. Durante o período democrático, Portugal começou cómoda e tranquilamente pelo quadrante virtuoso (C), ainda no rescaldo de uma ditadura conservadora e nacionalista, com fraca abertura financeira ao resto do mundo. O financiamento da dívida pública, ainda em níveis muito baixos, assentava em grande parte na componente interna não negociável, especialmente CA. De acordo com as estatísticas do $\mathrm{IGCP}^{40}$, ainda em 1980 a componente interna não negociável atingia 45,4\% da dívida pública total, o que conferia, de facto, à execução orçamental e à gestão financeira do Estado uma elevada previsibilidade e estabilidade, para além de evitar que grande parte das remunerações dos empréstimos fluíssem para o exterior.

38 Relatório Anual da Comissão de Finanças Públicas (2015).

39 Um documento do EUROSTAT, disponível em «http://ec.europa.eu/eurostat/documents/2995521/8068939/220062017-AP-EN.pdf», refere que Portugal é dos países que tem mais dívida na posse de não residentes - quase $60 \%$, sendo que mais de $30 \%$ de toda a dívida está nas mãos de entidades residentes mas de cariz financeiro, naturalmente com maior propensão para o seu tratamento de forma especulativa.

40 Disponiveis em www.igcp.pt. 


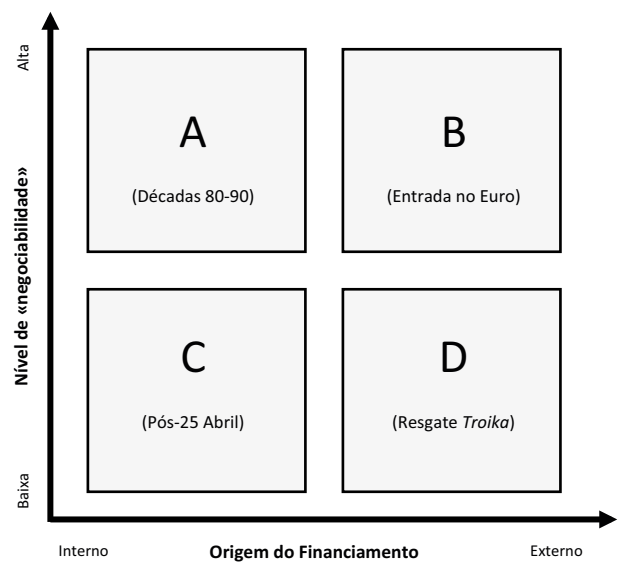

Fig. 9: Posicionamentos estruturais da dívida pública de um país

(Fonte: Elaboração própria)

Mais tarde, em meados da década de 80 e 90, com o aumento do rendimento das famílias e do capital disponível entre as empresas e bancos ${ }^{41}$, para além da modernização do mercado de dívida pública no sentido de aumentar a liquidez e a atratibilidade dos produtos e a facilidade de comercialização, o Estado acentuou a aposta em instrumentos de dívida de cariz mais transacionável, maioritariamente Obrigações do Tesouro (OT). Assim, em 1999, cerca de 93\% da dívida pública era detida por investidores residentes, a maior parte deles já de cariz institucional, sendo que 70\% da mesma tinha um cariz negociável (Quadrante A) ${ }^{42}$.

Nas imediações e em plena era de vigência do euro, no esplendor da globalização financeira, a tendência de apostar em títulos de dívida pública de elevado grau de negociabilidade acentuou-se, essencialmente através de emissões sindicadas e leilões. Para além disso, com o conforto de uma moeda forte e estável, como o euro, começaram a entrar de forma massiva investidores internacionais (a dívida deslocalizou-se para o quadrante $\mathrm{B}$ ), muitos deles de cariz profissional (como os grandes fundos de investimento), levando a que, no fatídico ano de 2008 , as OT já representavam $69 \%$ dos instrumentos de dívida pública - com os instrumentos não negociáveis a contribuir negativamente para o financiamento da República

41 Embora, tenha coincidido também com uma sensível redução da taxa de poupança das empresas e, em especial, das famílias. Segundo Fernando Alexandre et al. (op. citada), referindo-se a um estudo com Miguel Portela, a taxa de poupança das famílias desceu de $20 \%$ em meados da década de 80 para $10 \%$ em meados da década seguinte.

42 Os EUA, apesar de serem largamente os maiores devedores do mundo, apenas cerca de um terço dessa dívida pertence a estrangeiros. 
-, sendo que $77,1 \%$ do total da dívida pública estava nas mãos de não residentes, um dos valores mais altos de sempre, senão mesmo o mais alto. Finalmente, com a intervenção da troika, a estrutura da dívida pública posicionou-se no quadrante $\mathrm{D}$ - isto se considerarmos a dívida contraída àquela entidade como não negociável -, embora a componente negociável, pela sua dimensão absoluta, continue a ser uma fonte de nervosismo para os gestores do orçamento português. Qualquer espirro interno ou externo assusta os mercados, provocando instabilidade no planeamento e na execução orçamental. Basta ver que a componente de juros da dívida pública, a rondar os 8,2 mil milhões de euros, já representa algo como $11 \%$ do total da receita corrente e mais do dobro do investimento efetuado nesse ano.

Obviamente que o ideal para uma nação é manter-se no quadrante virtuoso (C). Para alguns ainda pode ser possível mas, face à dimensão da dívida pública, necessidades anuais de financiamento da Administração Pública e aos níveis de poupança doméstica, tal seria impossível. Resta-nos políticas públicas que paulatinamente mitiguem a componente transacionável e, em especial, externa da dívida.

No entanto, algumas decisões políticas num passado recente não foram muito felizes em termos de mobilização de particulares para aquisição de dívida soberana, no fundo aqueles que dão maiores garantias de estabilidade e de fidelidade. Por exemplo, a alteração das condições remuneratórias dos CA - uma marca histórica de elevada notoriedade e reconhecida confiança entre os portugueses -, para a sua quase desvalorização, desviou muitos fundos para aplicações alternativas, como depósitos bancários.

Contudo, primeiro com o aparecimento dos Certificados de Tesouro (CT), a oferta de dívida soberana tornou-se muito mais atrativa em termos remuneratórios para os pequenos e médios investidores, que viram aí uma oportunidade de diversificar e, em especial, rentabilizar as suas poupanças face à anemia das aplicações sucedâneas de baixo risco. No entanto, o lançamento deste instrumento de dívida pública foi sempre algo tímido, parecendo mostrar mesmo algum receio que tal viesse a afetar os resultados operacionais das entidades bancárias face às alternativas por elas oferecidas ao investidor particular conservador, em especial os clássicos depósitos à ordem e a prazo, pauperrimamente remunerados. Sem se perceber bem porquê, em setembro de 2012 foram suspensos os novos lançamentos de CT.

Mais recentemente, numa jogada de alguma ousadia face a um certo «mainstream» de respeitinho pela banca, foram lançadas as chamadas Obrigações do Tesouro de Rendimento Variável (OTRV), valores mobiliários representativos de empréstimos de médio e longo prazo da República Portuguesa, criados com o propósito de impulsionar o mercado de dívida pública através da diversificação dos instrumentos de dívida pública e dos canais de distribuição disponibilizados aos investidores e do alargamento da base de investidores 
em dívida soberana. Apesar de, na prática, ser tecnicamente classificada como dívida negociável, especialmente dirigida a investidores particulares com perfil de fraca tolerância ao risco ou até conservador, introduzem uma maior estabilidade e previsibilidade à evolução da estrutura e do custo da dívida pública a médio e longo prazo, rivalizando de forma direta com instrumentos de dívida genuinamente não negociável (CA e CT), mas também com a oferta clássica das entidades bancárias para as poupanças das famílias e empresas, que com elas também lucram sob a forma de comissões de vendas aos balcões.

O seu sucesso prova que os portugueses têm confiança na dívida do seu país, pelo que será seguramente uma aposta a manter e, se possível, a intensificar-se, até porque, segundo os últimos dados recolhidos, só em depósitos bancários existem mais de 140 mil milhões de euros em Portugal ${ }^{43}$. A ideia a seguir passa por transferir necessidades de financiamento satisfeitas junto dos investidores institucionais, mesmo que residentes em território nacional, para o público em geral ${ }^{44}$. Mas para que tal resulte as taxas de remuneração dos instrumentos de dívida pública dirigidos a particulares residentes têm de ser atrativas e assumir-se como uma alternativa credível face às demais, mesmo que tal signifique afrontar o poder da banca e dos poderosos fundos de investimento internacionais.

A este propósito, vale a pena trazer aqui à colação a teoria da democratização da dívida, explanada por José Teixeira ${ }^{45}$, com base na doutrina de De Viti de Marco ${ }^{46}$. Segundo a mesma, no seu conceito purista, numa sociedade inicialmente muito desigual, quando o Estado emitia dívida, dirigia-se a quem detém relativamente mais capital disponível, normalmente as classes mais abastadas. Ora, para amortizar essa dívida, o Estado tem sempre de lançar impostos dirigidos não só àqueles, mas também aos restantes contribuintes, pobres e remediados, o que significa que os «capitalistas» são quem mais acaba por lucrar na consolidação das contas - o que pagam de impostos é mitigado com o recebimento de juros, enquanto que os restantes só pagam impostos.

No entanto, com o crescimento do rendimento disponível na chamada classe média, se o Estado conseguir atrair as suas poupanças em títulos de dívida pública, esta situação altera-se substancialmente, podendo esta também beneficiar de juros que amenizam o pagamento futuro de impostos para financiar a dívida pública emitida, equilibrando o

43 De acordo com os resultados do $2 .^{\circ}$ Inquérito à Literacia Financeira da População, promovido pela Autoridade de Supervisão de Seguros e Fundos de Pensões, BdP e CMVM (2016), 15\% dos portugueses guardam o dinheiro em casa, sendo que apenas $60 \%$ aplicam em depósitos bancários.

44 Se bem que o Banco de Portugal, por via do famoso programa de Quantitative Easing do BCE, se assume cada vez mais como um dos principais detentores de dívida soberana portuguesa, facto que, para além das questões de estabilidade e de retenção interna de riqueza já invocadas, tem um aspeto adicional importante: o potencial aumento dos dividendos a favor do Estado, que tendencialmente anulam os encargos com a dívida por ele detida.

45 Op. citada.

46 Vide Principii di Economia Finanziaria, Einaudi, Turim, 1934. 
esforço e levando à sua amortização «democrática», no sentido de equitativa, deixando de ser encargo de apenas alguns estratos sociais mais desfavorecidos. Assim, até neste desiderato de aumentar a parcela da dívida pública interna não negociável, para além das considerações que fizemos em termos de soberania, liberdade decisória e manutenção da riqueza em solo nacional, prosseguem-se objetivos de justiça e igualdade sociais.

Atente-se que, em teoria, se o investidor particular fosse um ser estritamente racional e totalmente informado, a remuneração de uma aplicação em dívida pública deveria, em termos líquidos, no mínimo ser igual à taxa de juro praticada no mercado primário deduzida do efeito de evitamento dos impostos que teria de pagar caso o Estado ali se financiasse. Exemplificando: suponhamos que o Estado consegue colocar no mercado primário dívida pública a $3,5 \%$ e que a carga fiscal que impõe aos seus contribuintes para garantir saldo orçamental total nulo é de $40 \%$. Neste caso, o tal idílico investidor, antecipando o que iria pagar de impostos para cobrir os encargos dessa nova dívida a emitir, exigiria no mínimo uma remuneração depois de impostos de $2,1 \%{ }^{47}$ para patrioticamente adquirir títulos alternativos de dívida pública. E é também esse, no plano estritamente da racionalidade financeira, o limite de remuneração líquida que o Estado deve poder oferecer aos investidores particulares nas condições aqui simuladas.

Claro que com isto não queremos dizer que se pode e deve descurar a aquisição de dívida pública nos mercados financeiros, dominados por investidores institucionais. Estes serão sempre importantes, já que para a satisfação integral das imensas necessidades de financiamento da Administração Pública não chegam as poupanças dos particulares, longe disso. E, para tal, muito ainda pode ser feito, à semelhança da experiência italiana: aumentar a atratibilidade do mercado de dívida pública nacional, estimulando a procura e baixando assim a taxa de juro associada, através, por exemplo, da dinamização do mercado de derivados e futuros a ela associados. Na verdade, embora por vezes tal seja obnubilado, a questão da volatilidade e da liquidez, para além da confiança na solvabilidade da dívida, também são fatores de ponderação para os investidores profissionais.

Resta dizer sobre isto que ainda existe mais um importante elemento de configuração do stock da dívida soberana: a sua composição em moeda estrangeira. Se bem que não seja tão importante para países membros da UE, pois possuem uma moeda comum de grande credibilidade e forte no panorama internacional, esta questão pode assumir uma grande relevância noutros países com moedas frágeis e com elevada exposição a dívida com moeda estrangeira, fazendo adicionalmente emergir um risco cambial. Portugal apresentava em 
finais de 2016 uma dívida direta do Estado em moeda não euro somente na ordem dos 1,8\% do total ${ }^{48}$, o que relega este aspeto para plano secundário.

\section{Será adequado o controlo interno e externo das contas públicas?}

Não obstante a obrigatoriedade legal e moral de assegurar disciplina financeira e orçamental num espaço com moeda única, não nos parece fazer muito sentido o famoso teto de $3 \%$ de défice global face ao PIB, imposto pelas regras europeias. Podemos começar, de resto, pela explicação original do seu cálculo pelo seu criador, Guy Abeille, ex-conselheiro económico do antigo presidente francês, François Mitterrand, numa entrevista ao jornal «Le Parisien» (edição de 28SET2012). Segundo as suas palavras, nunca desmentidas, tendo em conta o pouco tempo que o presidente lhe deu para essa espinhosa tarefa - este estava a poucas horas de viajar de avião -, basicamente socorreu-se de alguma intuição, bom senso e até de alguma inspiração divina, pois era numericamente equivalente, disse Abeille, com a «santíssima trindade»! Na verdade, aquele histórico governante francês pretendia colocar um limite psicológico fácil de reter aos ensejos despesistas dos seus ministros, tendo então sacralizado esse valor como travão. Mais tarde, como sabemos, foi acolhido no seio das negociações de Maastricht.

Mesmo no plano material, a opção pelo saldo global como referência de controlo orçamental tem diversas condicionantes. Na verdade, uma nação pode ter o seu défice global equilibrado, mas apresentar um desequilíbrio intrínseco, como, por exemplo, ter o saldo corrente cronicamente deficitário, colmatado por um excedente de capital que, de forma contraproducente, vai conseguindo obter. Por exemplo, estar a financiar a insustentabilidade da sua segurança social com receitas provenientes de privatizações, solução que apenas é válida enquanto houver «joias» para vender. É como se uma família financiasse roupa com venda de património. A prazo, as fragilidades dessa opção irão inevitavelmente emergir, obrigando-a a mudar de vida ou abrir insolvência.

Existe atualmente uma certa tendência para empolar em demasia o chamado saldo primário, isto é, o saldo global expurgado das despesas com encargos da dívida pública. Fala-se mesmo na obrigação de criar saldos primários excedentários como única forma de pagar a dívida soberana. Por tudo o que foi dito atrás, somos obrigados a discordar em boa parte. Aliás, este indicador, que tem inequivocamente algumas virtuosidades, pois evidencia e submete a escrutínio a globalidade das opções de governação financeira diretamente imputáveis aos decisores, sofre dos mesmos problemas que o saldo global, já que permite ocul- 
tar eventuais desequilíbrios na consolidação entre saldos correntes e de capital. Mais, por ignorar os juros da dívida pública, podemos ter saldos primários excedentários, mas não os conseguir absorver com a totalidade das receitas cobradas, obrigando assim o país a contrair dívida para pagar juros de dívida - a tal dívida duplamente viciosa.

Na sequência da crise financeira de 2008, a UE introduziu, através do TO, um limite mais criterioso de controlo do défice orçamental, ao excluir as medidas extraordinárias e temporais e ao depurar os efeitos do ciclo económico - o chamado saldo estrutural -, segundo o qual o correspondente défice não deverá ultrapassar 0,5\% do PIB. No entanto, sendo sem dúvida uma tentativa bem-intencionada e, de certa forma, bem conseguida para obtenção de um retrato mais fiel das opções de política orçamental controladas pelos estados-membros e poder assim responsabilizá-los de forma mais apropriada, peca novamente por não dar tratamento diferenciado às contas corrente e de capital. Para além disso, o seu apuramento reveste uma significativa complexidade e alguma discricionariedade, o que nunca é bom nestes processos.

Seja como for, pouco há a dizer no plano teleológico quanto a estas imposições comunitárias, independentemente da maior ou menor credibilidade da fixação dos valores "mágicos" de $0,5 \%$, 3\% e 60\% do PIB, se bem que, no plano metodológico, deveria haver uma abordagem flexível em função do estádio de desenvolvimento socioeconómico de cada país. Se assim já acontece em algumas decisões importantes da UE, como a atribuição de fundos estruturais, não se vislumbra que isso não pudesse acontecer para a fixação de limites ao saldo orçamental e em especial à dívida pública, o que provocaria um crescimento mais harmonioso do bloco económico europeu. Isto não invalida que, como vimos, em nome de princípios de coerência doutrinária e de rigor, pudesse existir uma imposição comunitária de âmbito universal no sentido de manter o saldo corrente em valores nulos ou superavitários, o que imporia uma disciplina acrescida a países por tradição menos focados nesse desiderato, como Portugal.

A nível interno, também a Constituição da República Portuguesa (CRP) estabelece alguns parâmetros de controlo formal do próprio processo de elaboração orçamental, que assim ganham uma força legislativa suplementar. Nesta matéria podemos dizer que exerce dois tipos de controlo: um genérico, visando assegurar a observância de princípios essenciais de um Estado de Direito, alguns deles recorrentemente invocados em sede de fiscalização preventiva e sucessiva da constitucionalidade dos orçamentos (ex: princípios da universalidade, proporcionalidade e da igualdade); e um específico, versando sobre regras basilares inerentes ao processo de conceção e aprovação do orçamento de Estado.

Em tempos como os atuais, com a discussão da constitucionalidade dos orçamentos a adquirir uma especial centralidade no debate político, nomeadamente a sua adequação 
aos tais princípios gerais no âmbito do controlo genérico, não deixa de ser curioso que uma das regras inclusas no $n .^{\circ} 4$ do art. $^{\circ} 105 .{ }^{\circ}$ da CRP - o equilíbrio orçamental no plano formal - praticamente nunca foi respeitada desde a Revolução dos Cravos, pelo que, numa interpretação literal e rígida da norma, todos esses orçamentos seriam à partida inconstitucionais, como algumas individualidades no meio empresarial e académico vieram lembrar. Na verdade, uma leitura rígida poderia levar-nos a pensar que o legislador teve uma deriva da mais pura ortodoxia liberal, decalcado do pensamento financeiro clássico, vigente no Estado Novo. No entanto, numa interpretação sistemática, resulta de forma mais ou menos explícita a admissão natural e lógica das chamadas receitas creditícias. Seja como for, no seu todo, resulta numa formulação de cariz meramente formal, pouco exigente e até algo improfícua.

A Lei de Enquadramento Orçamental (LEO), na sua formulação atual ${ }^{49}$, opta por excluir o chamado Princípio do Equilíbrio anteriormente contemplada na sua anterior versão ${ }^{50}$, assente num critério clássico definido de duas formas diferentes: por um lado, impondo aos serviços integrados o equilíbrio ao nível do saldo primário, o que permitia, no fundo, contrair empréstimos para amortizar dívida antiga e/ou os respetivos encargos, que é o mesmo que dizer dívida duplamente viciosa; pelo outro, no que respeita aos Fundos e Serviços Autónomos e à Segurança Social, o equilíbrio radica no saldo global, legitimando apenas a contração de empréstimos para efetuar amortizações ou reembolsos de outros já assumidos.

Em substituição desse antigo Principio do Equilíbrio, a LEO introduz outros preceitos mais prescritivos, uniformes e, de certo modo, exigentes, replicando o que já se encontra nos tratados europeus sobre a matéria, nomeadamente o PaEC e o TO. Em concreto, o seu artigo 9..$^{\circ}$ dedica-se a estabelecer o chamado Principio da Sustentabilidade das Finanças Públicas, segundo o qual as entidades que constituem o setor das administrações públicas «devem assegurar capacidade de financiar todos os compromissos, assumidos ou a assumir, com respeito pela regra de saldo orçamental estrutural e da divida pública, conforme estabelecido na presente lei».

Nos artigos $20 .^{\circ}$ e seguintes, a LEO vem definir de forma objetiva e numérica os limites considerados de sustentabilidade, já anteriormente aludidos, havendo uma preocupação acrescida em gerir os efeitos e as medidas contracíclicas. Para além disso, enuncia as diversas aplicações dos excedentes e a correção dos desvios orçamentais ao longo do tempo. Curiosamente, não faz alusão à sacrossanta regra do $3 \%$ de défice global sobre o PIB, optando por privilegiar a regra do saldo estrutural, sem, contudo, deixar de exigir 
saldos globais nulos ou excedentários aos diversos subsetores da Administração Central, incluindo a Segurança Social.

\section{Conclusão}

A dívida pública portuguesa cresceu nos últimos anos a um ritmo galopante, apesar de ter partido de uma situação aparentemente confortável na década de 1980. Tal comportamento foi extensível ao setor privado, que também viu os seus índices de endividamento subir a um nível incompatível com um salutar e regular crescimento económico, também por força da diminuição drástica dos encargos associados. No entanto, a eterna questão da sustentabilidade da dívida acaba por ser o centro de uma discussão inútil, pois está por demonstrar um indicador credível que lhe sirva de métrica. A mesma depende da perceção dos atuais e potenciais investidores quanto à probabilidade de verem o seu capital devolvido pelos Estados, juntamente com a remuneração que lhe está associada. E isso tem muito de subjetivo, de emotivo e até por vezes de irracional, dados os habituais comportamentos de «manada» típicos dos mercados financeiros.

A dívida pública, independentemente do seu nível, pode ser mitigada por diversas formas. O crescimento económico representa a modalidade mais salutar, mas também é a mais difícil. A inflação dá uma ajuda «grátis», mas tem diversas externalidades negativas que podem pôr em causa o bem-estar socioeconómico de um país. Embora hodiernamente defendida pela doutrina reinante, as políticas de austeridade credibilizam a governação perante os credores, mas historicamente apresentam resultados muito discutíveis no que toca ao efetivo abatimento da dívida pública - podem até ter efeitos contrários -, sendo que, seguramente, fragilizam as nações noutros domínios, quando são empurradas a alienar ativos, por vezes estratégicos, em condições pouco vantajosas e apressadas, a cortar investimento e a mitigar a sua despesa de cariz social.

Seja como for, como procurámos demonstrar, contrair dívida não é sempre um exercício de necessidade extrema ou até de leviandade gestionária. Pode decorrer de uma governação atenta, justa e inteligente, pois pode até ser contraída quando não necessária no plano meramente contabilístico e financeiro, com a finalidade, entre outras, de prossecução de princípios de equidade intergeracional. No entanto, há que avaliar a natureza genética da dívida. Quando se destina a cobrir défices de capital provenientes da assunção de investimentos públicos reprodutivos, ela assume um figurino virtuoso, saudável, pois visa, em última instância, obter retorno económico num futuro mais ou menos próximo. Mas quando apenas se destina a suprir necessidades de financiamento de défices correntes ela assume geneticamente uma natureza viciosa. Agrava-se, quando é utilizada para pagar 
juros de dívidas antigas, tornando-se duplamente viciosa. Tal facto, infelizmente, tem sido a prática em Portugal, onde, por exemplo, só nos últimos 16 anos, mais de um terço da nova dívida pública se destinou a pagar encargos da anterior.

Este percurso nocivo e, de certa forma, discreto e silencioso das contas públicas portuguesas, tal como de outros países europeus, não tem sido seriamente enfrentado pela UE, tão obcecada que está com parâmetros dogmáticos de controlo das contas nacionais de cariz pouco científico e de eficácia duvidosa, como os famosos limites para o défice e dívida pública face ao PIB. Nem sequer por via dos vários mecanismos de controlo financeiro a nível interno, por tradição pouco exigentes neste capítulo e acriticamente obedientes às receitas europeias. É uma questão cultural e histórica, diríamos, provavelmente só contornável através de um qualquer «choque térmico», como, por exemplo, a introdução, com força constitucional, da obrigatoriedade de cumprir saldos correntes equilibrados, eventualmente depurados de medidas extraordinárias de relevo, ao invés do tradicional foco no saldo global, estrutural ou não. No fundo, confrontado com um volume de receita praticamente perto do seu limite, seria uma forma de abater seriamente despesa corrente, quiçá por via da eternamente adiada reforma do Estado.

Efetivamente, mais do que o volume da dívida pública, deveríamos debater a sua génese material a nível nacional. Se pensarmos bem, no plano das relações privadas, quem no seu perfeito juízo empresta dinheiro a outrem para que este possa honrar o pagamento dos juros das dívidas que contraiu em tempos? É por isso importante obter quanto antes - sob pena de voltarmos a ver os senhores do fraque e entrar altivamente no Ministério das Finanças - uma ampla convergência na sociedade civil no sentido de controlar os principais focos de destabilização orçamental que atropelam esse desiderato. Falamos, essencialmente, do ainda elevado índice de massa adiposa do Estado, o peso crescente das pensões de velhice, os gastos exponenciais no setor da saúde e o volume assustador de encargos com a dívida pública, ainda com uma taxa implícita muito pesada face a países ocidentais com uma situação comparável à nossa. Isto contando que o ainda fragilizado setor bancário não traga mais surpresas desagradáveis.

Por outro lado, assume também especial preocupação o facto de a dívida pública portuguesa, depois de ser maioritariamente baseada em entidades residentes de natureza não especulativa (populares e investidores institucionais sem pretensões especulativas), o que conferia à sua remuneração atual e futura uma forte previsibilidade e estabilidade, ter-se posicionado num quadrante de elevada instabilidade, onde os investidores institucionais com fins de rentabilização de capitais próprios e alheios, maioritariamente externos, assumem a «fatia de leão». Estes, baseados em avaliações de agências de rating com critérios nem sempre percetíveis ou até algo opacos, não raras vezes tendo por base razões de ordem 
ideológica e preconceituosa, com um poder de influência transnacional ao mais alto nível, acabam sempre por criar dependências nos países devedores, que se veem assim desprovidos de parte da sua soberania nacional. Neste aspeto, as próprias estâncias da União Europeia têm dado exemplos que não podem ser considerados absolutamente felizes, sendo cada vez mais indisfarçáveis os tratamentos diferenciados entre grandes e pequenos países.

Por outro lado, o facto de a maioria dos credores ser entidades não residentes - muito à conta de um secular défice externo, em especial na balança de bens, bem como, mais recentemente, de uma significativa quebra da poupança interna - faz com que exista uma transferência de riqueza do país para o exterior, o que não acontece quando a dívida é maioritariamente interna. Os riscos para a autonomia e até para a segurança estratégica de uma nação aumentam quando os principais devedores estão alinhados com pretensões do foro geoeconómico ou até geopolítico de outros países mais interventivos na senda mundial, já que aquela acaba por ser, de uma forma ou de outra, uma mera plataforma para os seus interesses expansionistas. Daí que se torne especialmente importante, quando se assiste a uma reconfiguração geopolítica à escala global, que as autoridades portuguesas mitiguem as vulnerabilidades nacionais neste domínio, podendo começar por diminuir o peso da componente de dívida pública externa negociável ${ }^{51}$.

Talvez a substituição paulatina da dívida da troika, para além de toda a outra que irá rolar no futuro, seja uma oportunidade para cativar investidores residentes a adquirirem títulos do tesouro que efetivamente sejam atrativos do ponto de vista remuneratório face aos tradicionais produtos sucedâneos, como por exemplo os depósitos a prazo. Tal como, obviamente, a prossecução do tão almejado crescimento económico sustentado, essencialmente à base de mais exportações, menos importações e, associado a isso, investimento com a menor incorporação possível de bens e serviços externos.

\section{BIBLIOGRAFIA}

FERNANDES, Abel Costa, Economia Pública - Eficiência Económica e Teoria das Escolhas Públicas, Edições Sílabo, 2. ${ }^{a}$ Edição, Lisboa, 2011

ABREU, Alexandre et al., A Crise, a Troika e as Alternativas Urgentes, Tinta da China, Lisboa, 2013 Andrew White and David Uren, Ausgrid sale: China's State Grid prowls worldwide for assets, in The Australian Business Review (09/08/2016) Fernando Alexandre, Luis Aguiar-Conraria e Pedro Bação, Crise e Castigo, FMS, Lisboa, 2016 José Félix Ribeiro, Portugal, a Economia de uma Nação Rebelde, Guerra e Paz Editores, 2. Edição, Lisboa, 2014 
Carlos Moreno, Finanças Públicas - Gestão, Controlo e Auditoria dos Dinheiros Públicos, UAL, $3 \cdot{ }^{a}$ Edição, Lisboa, 2006

Domingos Pereira de Sousa, Finanças Públicas, ISCSP, Lisboa, 1992

Eduardo Paz Ferreira et al., A austeridade cura? A austeridade mata?, Lisbon Law School Editions, Lisboa, 2013 Emanuel Augusto dos Santos, Sem Crescimento Não Há Consolidação Orçamental, Edições Sílabo, Lisboa, 2012

J. Albano Santos, Finanças Públicas, INA Editora, Oeiras, 2010

Jean-Claude Drouin, Os Grandes Economistas - Uma Introdução à Economia, Edições Texto \& Grafia, Lisboa, 2011

João César das Neves, As 10 Questões da Recuperação, D. Quixote, Alfragide, 2012

Jorge Correia de Cunha e Cláudia Braz, A Evolução da Despesa Pública: Portugal no Contexto da Área do Euro, Boletim de Inverno do Banco de Portugal, Lisboa, 2013

Jorge Nascimento Rodrigues, Portugal na Banca Rota, Centro Atlantico.pt, V. N. Famalicão, 2012 José Carlos Soares, Dicionário de Economia, Plátano Editora, Lisboa, 2008

José Teixeira Ribeiro, Lições de Finanças Públicas, Coimbra Editora, 5. ${ }^{a}$ Edição, Coimbra, 1997

José Torres, Não Temos de Ser Alemães, Editora Matéria-Prima, Lisboa, 2014

José Torres, Dívida Pública e Soberania Nacional, ISCPSI, Lisboa, 2017

Leonor Freire et al., História Económica de Portugal (1143-2010), A Esfera dos Livros, Lisboa 2011

Luciano Amaral, Economia Portuguesa - As Últimas Décadas, FFMS, Lisboa, 2010

Maria Inês Marques Ferreira Alves, O Pacto de Estabilidade e Crescimento, o Investimento Público e o desempenho das políticas orçamentais na União Europeia, Tese de Mestrado em Economia, Instituto Superior de Economia e Gestão, Universidade Técnica de Lisboa, 2004

Marco Buti, A sustentabilidade das Finanças Públicas e o PEC, apresentado na Conferência de 13 de Dezembro de 2004 «A sustentabilidade das finanças públicas no médio/longo prazo» da Comissão de Execução Orçamental, Assembleia da República, 2004

Paul Krugman, Acabem Com Esta Crise Já!, Editorial Presença, 3. Edição, Lisboa, 2012

Paulo Trigo Pereira, Portugal: Dívida Pública e Défice Democrático, FFMS, Lisboa, 2012

Philippe Askenazy et al., Manifesto dos Economistas Aterrados, Actual Editora, Lisboa, 2011

Relatórios Anuais do Banco de Portugal e principais documentos orçamentais da DGO (Orçamento e Conta Geral do Estado) 


\title{
The structuring principles of Mediation in Portugal
}

\author{
RUBEN BAHAMONDE'
}

GALILEU - REVISTA DE DIREITO E ECONOMIA - e-ISSN 2184-1845

Volume XIX - $1^{\text {st }}$ July Julho $-31^{\text {th }}$ December Dezembro $2018 \cdot$ pp. 131-153

DOI: https://doi.org/10.26619/2184-1845.XIX.2.6

Submitted on September $4^{\text {th }}, 2018$. Accepted on November $11^{\text {th }}, 2018$

Submetido em 4 de Setembro, 2018 - Aceite a 11 de Novembro, 2018

ABSTRACT This paper focuses on the description and analysis of the principles that structure and guide mediation as an alternative means of conflict resolution in the Portuguese legal system. To this end, mediation will be individualized and differentiated from other alternative means of conflict resolution, and its advantages and disadvantages will be highlighted. Subsequently, the article will focus on the densification of each of the prevailing principles in mediation: voluntariness, confidentiality, impartiality, responsibility, competence, and enforceability, among others, to identify the interpretive problems that may arise in a practical situation. How these principles interact in the different stages of the mediation process will be explained, as well as the possible subjects of this procedure. Finally, we will make some recommendations for better dissemination and implementation of mediation as a means of conflict resolution.

KEYWORDS Alternative means of conflict resolution, mediation, principles, mediability, voluntariness, impartiality, independence, enforceability.

\section{Conflict and its historical approach}

All societies or collective groups are characterized by a great diversity of individual and collective interests at stake among their elements. This multiplicity of interests generates, of course, several points of friction between interests that may be seemingly antagonistic, thus leading to conflicts ${ }^{2}$.

1 Assistant Professor in the Department of Law of the Universidade Autónoma de Lisboa, Director of the Ratio Legis. Research Centre.

2 In the Portuguese language dictionary, conflict is defined as a clash of opposing elements; discord; antagonism or opposition, See (2017.11.23) https://www.priberam.pt/dlpo/conflito 
Consider, for example, the attribution of an individual or collective right that will necessarily entail the imposition of an equally individual or collective obligation, which will subsequently translate into a potential situation of conflicting interests. However, the existence of conflicts is not in itself positive or negative, but constitutes necessary dynamics for the evolution of the individuals and societies ${ }^{3}$. The positive or negative outcome that may result from the conflict in question is closely connected with how the parties decide to deal with the conflict. Given these assumptions, it can be affirmed that there will be peace when there is good conflict management and absence of peace will be the result of inadequate conflict management.

Our objective in this intervention is not to characterize and qualify the various sources of conflict, but rather to identify the various existing instruments for the management of conflict in order to obtain the best results possible, particularly focusing on mediation. When the management of a conflict results in the satisfaction of the claim of only one party or in the dissatisfaction of both parties, this is a bad result in the outcome of the conflict. However, if the result of the conflict allows for the integration of the conflicting interests in question, it can be easily qualified as positive.

In the most primitive forms of society, self-protection, or making justice by one's own hand was the most common means to resolve conflicts. However, the diversification of individuals and the growth of communities required the creation of objective rules capable of guaranteeing the maintenance of social peace and community life. The famous Law of talion foreseen in the Hammurabi Code, $1780 \mathrm{BC}$, in the kingdom of Babylon, is a clear manifestation of this affirmation that translated into "an eye-for-an eye", making a clear match between the crime committed and the punishment to be had. With this rule, which regulated self-defence, the injured party was granted the right to take revenge on the aggressor, thereby causing the latter the same damage suffered by the former, which increased the scale of the conflict.

The development of social realities demanded the paradigm shift from the traditional self-regulation system to another paradigm of multiple protection, in which the monopoly of the decision in a conflict situation was attributed to a third party, judge or court ${ }^{4}$. It is in this last model of multiple protection that the development of the justice system in mod-

3 See Eduardo Simões, "Gerir Conflitos”, José Gonçalves das Neves, Margarida Vaz Garrido and Eduardo Simões, Competências Pessoais, Interpessoais e Instrumentais, 3rd Ed., Edições Sílabo, Lisbon, 2015, pp. 210 and following; Lisa Parkinson, Mediação Familiar, Gabinete para a Resolução Alternativa de Litígios, Ministério da Justiça, Agora Comunicação, 2008, p. 15.

4 CAETANO, Marcelo - História do Direito Português. $4^{\text {a }}$ ed. Verbo, Lisboa 200o, pp. 12-14; DOMINGUES DE ANDRADE, Manuel - Noções elementares de processo civil, Coimbra Editora, Coimbra, 1993, pp. 1-2 e DE FIGUEIREDO DIAS, Jorge - Direito Processual Penal, Coimbra Editora, Coimbra, 2004 pp. 25-26. 
ern societies has been based, with greater or lesser divergences. Indeed, States, through the judiciary, i.e. courts, monopolistically guarantee the obligation to coercively resolve conflicts that are placed before them and which they must know in order to satisfy the effective judicial authorities ${ }^{5}$.

It is clear that the current judicial structures, despite their many virtues, are also characterized by some important failures, such as procedural delays, mental weariness, financial costs, opportunity losses, and the removal of those affected from the decision-making process of their conflict, among others ${ }^{6}$. Then the Alternative Dispute Resolution, which although not totally unknown, appeared at the beginning of the last century and have since played a more important role in the resolution of conflicts, both disseminating them and addressing them more in-depth and in a more systematic way ${ }^{7}$. Before continuing, it should be made clear that despite that fact that the concepts of conflict and dispute have different nuances, since the latter is a kind of the former, in this paper they are used interchangea$\mathrm{bly}^{8}$. Thus, within the various means of alternative dispute resolution, we have negotiation, mediation, conciliation and arbitration.

\section{Alternative dispute resolution methods}

The purpose of alternative dispute (ADR) resolution methods is not, in our view, to replace the important role of the judiciary, but rather to complement this function by allowing the parties to a conflict to opt for the method of resolution that is more suitable for the interests at stake, thus giving rise to the concept of "multi-door justice" . An alternative method of settling disputes is one that allows a conflict to be terminated by a route other than a court decision.

In this paper, we will focus on the role of mediation, but in order to better understand this topic, it is essential to characterize, albeit succinctly, the remaining methods of alter-

5 Issues that do not have to be taken before a judge.

6 See Justice in the EU Review Panel for the year 2017 published on 10 April, available at (2017.11.23): europa.eu/rapid/ press-release_IP-17-890_pt.pdf

7 A. Fernández Barreiro, Javier Paricio, Fundamentos de Derecho Privado Romano, 3rd Ed., Editorial Centro de Estudios Ramón Areces, 1997 pp. 140-142, noting that in parallel with ordinary jurisdiction, there have been private arbitrations since II.BC., and also arbitrations in which the parties were obliged to submit the dispute to the assessment of an arbitrator over institutional jurisdiction. Mariana França Gouveia, Curso de Resolução Alternativa de Litígios, 2nd Ed. Almedina, Coimbra, 2012, pp. 25-28.

8 Dulce Lopes, Afonso Patrão, Lei da Mediação Comentada, 2nd Ed., Almedina, Coimbra, 2014, pp. 12-13.

9 Ibid. 26. This idea is further reinforced by the fact that in the Portuguese legal system, Article 273 of the Code of Civil Procedure provides for the possibility of suspension of proceedings to resort to mediation and should this fail, then this suspension will automatically cease and the case will again be decided by the Judge. 
native dispute resolution. They may be characterized as voluntary or compulsory, adjudicatory or consensual and based on principles or on the law.

Firstly, we have a voluntary alternative method when the parties willingly submit the conflict in question to resolution by that particular means. On the contrary, the method will be compulsory when the parties are unable to resolve the dispute through a means of their choice, as for example in compulsory arbitration.

Secondly, there will be alternative adjudicatory methods of settling disputes when the parties give a third party the power to decide on the dispute, and undertake to comply with the decision. Conversely, the method will be consensual when the parties are able to accept or not a given result. This is known as empowerment, or being in command of the process.

Finally, the conflict can be resolved by taking into account purely legal criteria, i.e. in accordance with positive law, or it can be settled by following principles such as equity. The characterization of the various alternative methods of settling disputes is made clearer by the following table:

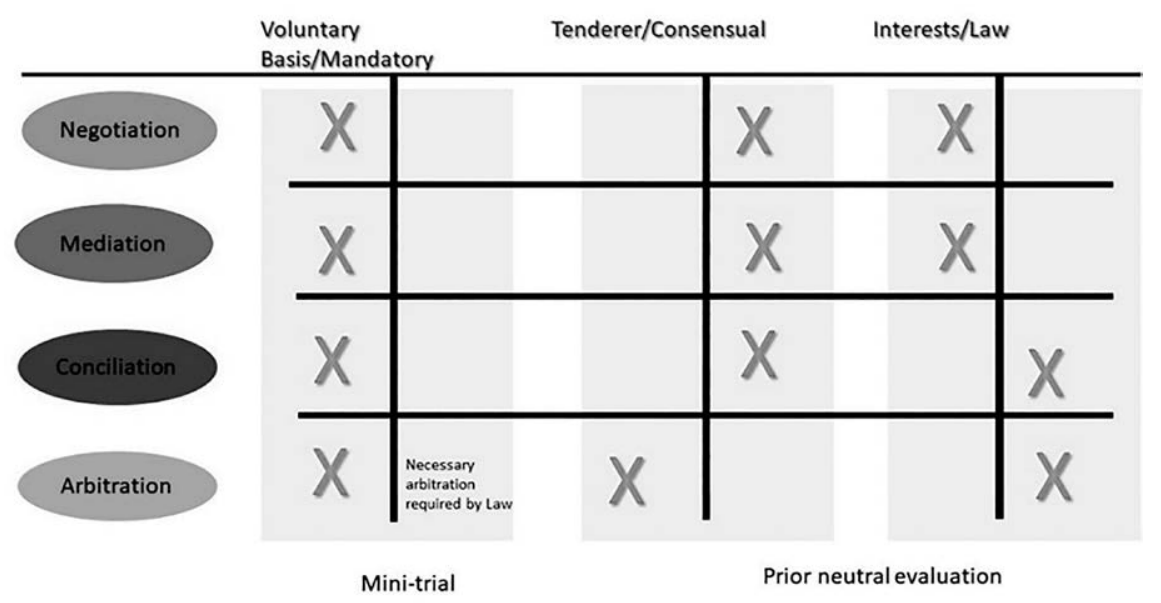

The first alternative method of dispute resolution referred to is negotiation. There are some authors who disregard this form as an alternative form of settling disputes by stating that it is a technique that can be used in any of the other alternative methods of dispute resolution, so it would be merely instrumental. However, in our view, such an understanding does not remove from negotiation its own entity and autonomy, insofar as it may be the only method used to resolve a conflict effectively without having to resort to any other.

Negotiation as a conflict resolution technique is used daily by all people in the most diverse contexts, and there are several negotiation methods, such as disruptive negotia- 
tion, negotiation of positions, or negotiation of interests, among others ${ }^{10}$. In the field of negotiation, the principled negotiation postulated by Harvard's choice has been gaining ground. It is based on an integrative and objective principle aimed at maintaining relations between the parties involved in the process in question ${ }^{11}$. In negotiation, the parties to the conflict have full control over the process and voluntarily decide whether to abide or not by the outcome of the process. The advantage of this method is the satisfaction of the claims of both parties, allowing a better and more peaceful maintenance of their relationship through a reciprocal commitment solution.

With regard to arbitration, and because it is not the main part of our subject, we can briefly characterize it as the alternative means of settling disputes that is more similar to the judicial process. This variant is an adjudicatory conflict heterocomposition method that may be voluntary or compulsory, as the case may be, and that may be about principles or about law, the latter being the most frequent ${ }^{12}$. The alleged advantage of this method traditionally consists in its great celerity, in its confidential nature and in the significant reduction of costs for the parts. Nevertheless, these attributes are not peacefully accepted by the doctrine ${ }^{13}$. In contrast to negotiation, in arbitration the parties are usually represented by others, and will typically deal with legal issues, not interests, and therefore the process always results in a loser and a winner. Thus, this form of dispute resolution does not take into account the re-establishment or maintenance of the relationship between the parties to the dispute, but only the decision as to whether the position adopted by each of them is legal or not.

\section{Mediation in Portugal}

Broadly speaking, the consecration of mediation as a form of settling disputes was reinforced in the Portuguese legal system in 2001, through article 16 of Law no. 78/2001, of 13 July, which created the Justice of the Peace ${ }^{14}$, by creating a mediation service within them..$^{15}$

10 See Eduardo Simões, "Negociar", José Gonçalves das Neves, Margarida Vaz Garrido and Eduardo Simões, Competências Pessoais, Interpessoais e Instrumentais, 3rd Ed., Edições Sílabo, Lisbon, 2015, pp. 233 and following. In a disruptive negotiation and in a negotiation of positions, there is a single negotiating interest that ends necessarily with a winner and a loser, the buyer wants to pay less and the seller wants to receive more.

11 Roger Fisher, William Ury and Bruce Patton, Como conduzir uma negociação, Translation by Maria João Goucha, 9th Ed., Lua de Papel, Lisbon, 2010.

12 Manuel Pereira Barrocas, Manual de Arbitragem, 2nd Ed., Almedina, Coimbra, 2013.

13 Jordi Nieva-Fenoll, “Mediación y Arbitraje: Una ilusión decepcionante?", Rafael Cabrera Mercado (Dir.) Pedro M. Quesada López (Coor.), La mediación como método para la resolución de conflictos, Dikinson, Madrid, 2017, pp. 15- 17.

14 This diploma on Justice of the Peace - Organization, competence and functioning was amended by Law no. $54 / 2013$, of $31 / 07$

15 The jurisdiction of the Justice of the Peace is limited to declaratory actions (article 6), whose amount does not exceed $€ 15.000,00$ (article 8) and whose matters fall within the list provided for in Article 9. 
Subsequently, following the publication by the European Commission of the European Code of Conduct for Mediators in $2004^{16}$ and the Directive on cross-border mediation in civil and commercial matters in $2008^{17}$, the legislator published Law no. 29/2013, of 19 April, where the institution of mediation in Portugal is definitively and autonomously established $^{18}$. A few months later, a specific European Directive was published on the alternative resolution of consumer disputes, which also consecrated mediation ${ }^{19}$.

In the European Code, mediation is defined as a process in which two or more parties agree to appoint a third party, the mediator, to assist them in resolving a conflict through an agreement without a ruling, regardless of how the process may be conducted in each Member State. In turn, Article 2 of the Portuguese Mediation Law welcomes the definition proposed by Directive 2008/52/EC and defines mediation as the form of alternative dispute resolution, carried out by public or private entities, through which two or more parties in conflict voluntarily seek to reach an agreement with the assistance of a conflict mediator ${ }^{20}$.

Accordingly, mediation is a process of self-protection that has the assistance of an impartial and independent third party, the mediator, deprived of powers of imposition to the parties, who assists them in the attempt to reach a final agreement on the object of the dispute. This mediating process, depending on the degree of intervention of the mediator, may be of an interventional nature, as the mediator is able to make proposals and values the merits of the issues, or it may be of a facilitative nature when the mediator's functions are restricted to the creation of channels of communication and understanding between the parties. It is this last model, of facilitating mediation, that was chosen by the Portuguese legislator. Such choice does not imply the discrediting of other methods of mediation ${ }^{21}$.

As regards the objectives sought by mediation, it is also clear from the Portuguese rule that we are faced with a process aimed at reaching an agreement between the parties, the positive outcome of which will depend precisely on the implementation of the agreement. Notwithstanding the foregoing, it has been argued that this kind of mediation directed at

16 Available at (2017.11.23): http://www.dgpj.mj.pt/sections/gral/mediacao-publica/mediacao-anexos/codigo-europeu-de/downloadFile/file/Codigo_Europeu_de_Conduta_para_Mediadores_13.03.2014.pdf?nocache $=1394707997.85$

17 Directive 2008/52/CE of the European Parliament and of the Council of 21 May 2008, on certain aspects of mediation in civil and commercial matters.

18 Law no. 29/2013, of 19 April, General Principles Applicable to Mediation - Civil and commercial mediation. For a detailed analysis of legislative developments in Portugal on mediation see Jorge Morais de Carvalho, "A Consagração legal da mediação em Portugal", Julgar, vol. 15, pp. 272-273.

19 Directive 2013/11/EU of the European Parliament and of the Council of 21 May 2013 on alternative dispute resolution for consumer disputes, amending Regulation (EC) no. 2006/2004 and Directive 2009/22/EC.

20 See (a) of Article 3 of the Directive, which defines mediation as a structured process, regardless of its designation or the way in which it is referred to, by which two or more parties to a dispute voluntarily seek agreement on the resolution of the dispute with the assistance of a mediator.

21 Mariana França Gouveia, Curso de Resolução ..., pp. 43-44. 
the agreement, typical of civil and commercial mediation, does not prove to be the best technique to mediate conflicts of another nature, such as family or criminal. In these cases, other models such as transformative mediation, ecosystemic mediation or narrative mediation are proposed. ${ }^{22}$

Currently in Portugal, there are public and private mediation systems. In the field of public mediation we can also distinguish between the mediation of generic competence, materialized in the Justice of Peace courts ${ }^{23}$, and the specialized mediation in the labour ${ }^{24}$, criminal $^{25}$ and family area ${ }^{26}$.

\section{A. The defining characteristics of mediation.}

As noted above, mediation is a process directed by a third party, the mediator, whose intervention is voluntarily requested by the parties to the dispute to assist them in obtaining a peaceful resolution of their dispute. As a method, and in contrast to judicial processes, mediation is distinguished by its informality, speed, and concern for the relationship between the mediated parties.

The exercise of justice within the judicial courts is characterized by high formalism that does not go unnoticed among those summoned there. It begins with the very disposition of the courtroom, where the Judge occupies a central and high place, while the parties sit in a lower position. The dark robes used by lawyers and judges also confer this formal and solemn character to the realization of justice.

At a trial, the judge directs the various procedural steps with authority, following the corresponding rules without giving the parties the possibility to change course. Regarding

22 On these types of mediation, see Lisa Parkinson, Mediação Familiar..., p. 42-53.

23 See articles 16 and 30-36 on the figure of the mediator and articles 49-56 on pre-mediation and actual mediation. On this, see João Chumbinho, Julgados de Paz na Prática Processual Civil, Quid Juris, Lisbon 2007 and João Miguel Galhardo Coelho, Julgados de paz e Mediação de Conflitos, Âncora Editora, Lisbon, 2003.

24 Labour Mediation System (SML) - Protocol of 5 May 2016 by the Ministry of Justice and the Social Partners to mediate conflicts resulting from individual employment contracts that deal with available rights and not resulting from an accident at work. Articles 525-528 of the Labour Code should also be stressed as far as collective labour disputes are concerned. On this matter, see António Casimiro Ferreira, "O sistema de resolução dos conflitos de trabalho: da formalização processual à efetividade das práticas", Revista Crítica de Ciências Sociais, no. 60, 2001, pp. 9-32.

25 Criminal Mediation System (SMP) - Law No. 21/2007, of 12 June, dealing with private crimes and some semipublic crimes. On this matter, see Mário Ferreira Monte, "Um balanço Provisório sobre a Lei de Mediação Penal de Adultos", Homenagem de Viseu a Jorge Figueiredo Dias, Paulo Pinto de Albuquerque (coord.), Wolters Klower, Lisbon, 2011. pp. 113-127.

26 Family Mediation System (SMF) - Dispatch No. 18, 778/2007, of 13 July. On this matter, see Rossana Martingo Cruz, Mediação familiar: Limites materiais dos Acordos e o seu controlo pelas Autoridades, Coimbra Editora, Coimbra, 2011 and Lisa Parkinson, Mediação Familiar, Gabinete para a Resolução Alternativa de Litígios, Ministério da Justiça, Agora Comunicação, 2008. 
mediation, although it is a structured process divided into several phases ${ }^{27}$, there is great flexibility that allows the mediator, together with the parties, to choose and establish the best organization of the process for the resolution of the conflict ${ }^{28}$. In addition, in mediation the physical environment in which the process is carried out is important, and conditions must be provided to foster equality and proximity between the parties, enabling them to assume the role of advocates of conflict resolution ${ }^{29}$. Finally, this simplicity is also due to the absence of lawyers in the mediation process, which facilitates and encourages direct communication between the parties involved..$^{30}$

The duration of the process is also seen as an advantage over traditional court forms, which is an express concern of the legislator when establishing, in many cases, a maximum period of three months, without prejudice to the fact that, at the request of the parties, it can be extended ${ }^{31}$. As far as private mediation is concerned, the law does not impose a maximum length of time for the process, for which reason it will be freely established by the institution concerned, as prescribed in Article 21 of the Mediation Law. The length of the judicial cases, which in Portugal generally allow a decision at a Court of First Instance within two years, would clearly be longer than in the deadline allocated to mediations ${ }^{32}$.

Lastly, the purpose of mediation is not to resolve the dispute on the basis of the legal merit of each of the parties' claims, but rather to promote the pacification of the parties, encouraging them to develop communication channels that allow them to come up with a stable, long-term and voluntary solution ${ }^{33}$. Moreover, mediation is not limited to resolving the existing conflict by obtaining an agreement, since it also aims to prepare the parties to

27 Javier Alés Sioli, Juan Diego Mata Chacón, Manual Práctico para Mediadores. El misterio de la mediación. Como gestionar un conflicto desde sus cenizas., Atelier, Barcelona, 2016, pp. 181-182; Mariana França Gouveia, Curso de Resolução..., pp. 62-78.

28 This absence of formality is specifically consecrated in labour mediation. See no. 2 of article 24 of the Manual of Procedures and Good Practices of the Labour Mediation System, Article 2 of Dispatch 18778/2007 and no. 1 of article 4 of Law 20/2007 of 12 June on criminal mediation. On this flexibility, see Enrique César Pérez Luño Robledo, “La mediación como Proceso?", Rafael Cabrera Mercado (Dir.) Pedro M. Quesada López (Coor.), La mediación como método para la resolución de conflictos, Dikinson, Madrid, 2017, pp. 54.

29 Roger Fisher, William Ury and Bruce Patton, Como conduzir uma negociação p. 178

30 For example, in the Justice of the Peace Courts the presence of the parties is compulsory, pursuant to article 38 of Law 78/2001 of 13 July. As for private mediation, the parties may be represented by others, pursuant to article 18 of Law 29/2013 of 19 April.

31 See no. 1 of article 21 of Law 29/2013 of 19 April, Point 6 of Directive 2008/52/EC, emphasizing the virtues of mediation as a quick and inexpensive solution to the dispute. Specifically, the public systems of criminal, labour, and family mediation in Portugal have a maximum duration of 3 months Cf. Article no. 1 of Law 21/2007 of 12 June; paragraph g) of Clause 4 of the Protocol.

32 See Point 3.1.1.1, figure 4 of the 2017 EU Justice Scoreboard published on 10 April 2017, available in (2017.11.23): europa.eu/rapid/press-release_IP-17-890_pt.pdf.

33 Jean Françoes Six, Veronique Mussaud, Médiation, Seuil, Paris, 2006, pp. 26 and following. 
resolve future conflicts between them ${ }^{34}$. Thus, although civil and commercial mediation is particularly geared to reaching an agreement between the parties, with regard to mediation in other areas such as the family, failure to reach an agreement can be a good result if the process have enabled the parties to open channels of dialogue and understanding of the interests and motivations of the parties ${ }^{35}$.

\section{B. The structuring principles of mediation}

As seen above, mediation is based on a specific conflict resolution logic that has resulted from concrete concerns about the traditional legal process regarding delays and distancing the parties from the solution. In order to safeguard the purposes it proposes, the mediation process must observe several principles, namely voluntariness, confidentiality, equality and impartiality, independence, responsibility, and enforceability ${ }^{36}$.

\section{a) Principle of voluntariness}

This principle is enshrined in Article 4 of the Mediation Law and implies that the use of mediation requires the informed consent of the parties and that the parties are responsible for decisions taken during the process ${ }^{37}$. As a result of this principle, the parties may, at any time during the mediation procedure, revoke their consent and withdraw from the mediation in progress without having to justify their decision, contrary to what happens in conciliation.

The principle of voluntariness is also evident in the adoption of the agreement eventually drawn up by the parties in so far as it is binding only if they accept it freely. The principle of voluntariness is not impaired in cases where a compulsory mediation system is imposed that entails the verification of mediation as a prerequisite, i.e. an action could only be brought before the courts once the mediation route has been exhausted.

As the doctrine broadly states, a compulsory mediation system on the terms set out would be within the scope of no. 1 of Article 20 of the Constitution of the Portuguese Republic (CRP) and Article 6 of the European Convention on Human Rights, as it does not

34 M. Lozano Martín, Tratado de mediación en la resolución de conflictos, Tecnos, Madrid, 2015, pp. 120 and following.; Lisa Parkinson, Mediação Familiar..., p. 19.

35 Javier Alés Sioli, Juan Diego Mata Chacón, Manual Práctico para Mediadores..., p. 108, states that, since an agreement is a positive outcome, "both the mediator and the parties to the dispute must consider that the decision not to reach agreement is an equally valid conclusion".

36 Articles 3-4 of the Mediation Law, Dulce Lopes, Afonso Patrão, Lei da Mediação Comentada... pp. 29-72; Enrique César Pérez -Luño Robledo, "La mediación como Proceso? ...", p. 54.

37 The principle of voluntariness is also implicitly enshrined in Directive 2008/52/EC of the European Parliament and of the Council of 21 May 2008 on certain aspects of mediation in civil and commercial matters, in particular Article 3 paragraph (a). 
prevent access to the effective judicial authorities and whenever such a prerequisite is not detrimental to the legal situations in question and appears necessary, proportionate and reasonable ${ }^{38}$. As we have seen, the parties cannot be harmed by the use of mediation, but another question posed here is the possibility of the State to encourage the use of alternative means of dispute resolution, in particular mediation, conferring advantages to those who use them. In these situations, there appears to be no obstacle to such a policy, since they are designed to ensure a better functioning of the system of administration of justice $^{39}$. (In Argentina there are sanctions).

Finally, within this voluntariness also lies the ability of the parties to choose the mediator or mediators who will guide the process as prescribed in Article 17 of the Mediation Law. This freedom suffers some deviations in the case of public mediation where the arbitrator is chosen randomly from among the mediators registered in the respective lists constituted for the purpose ${ }^{40}$. This feature is in clear opposition to the principle of the natural judge that prevails in ordinary jurisdiction and is enshrined in no. 9 of Article 32 of the CRP.

\section{b) Principle of confidentiality}

Article 5 of the Mediation Law establishes the confidentiality of the process, and the mediator must keep confidential all information he or she has knowledge of in the context of the mediation procedure, and may not use it for his/her own benefit or for the benefit of others. This principle also implies that the information revealed by one of the parties to the mediator cannot be communicated to the other party without the consent of the former, which is what happens in private or caucus sessions ${ }^{41}$.

Confidentiality is a fundamental pillar in the promotion of alternative means of conflict resolution and in particular in mediation. In effect, the parties would have very little openness to share or disclose information that was not accessible to the other party if such information could subsequently be used in court if mediation were thwarted. Moreover, in

38 Jorge Morais de Carvalho, "A Consagração legal da mediação ... p. 281. This issue is approached in the same way in the Spanish legal system. See Héctor Álvarez Garcia, "La premediación como presupuesto procesal de admisibilidad versus el derecho fundamental de acceso a la jurisdicción”, Rafael Cabrera Mercado (Dir.) Pedro M. Quesada López (Coor.), La mediación como método para la resolución de conflictos, Dikinson, Madrid, 2017, pp. 89 and following.

39 Dulce Lopes, Afonso Patrão, Lei da Mediação Comentada... pp. 36-37; Cátia Marques Cebola, "A mediação préjudicial em Portugal: Análise do Novo Regime Jurídico", Revista da Ordem dos Advogados, Ano 70, nos. 1-4, 2010, pp. 441-459. As this author points out, it is only with these incentives or privileges, such as the suspension of deadlines, that "it is possible to affirm it as a method of resolving conflicts of value similar to the judicial system, in the sense that it is an option that does not preclude the rights of the parties to find a solution to their conflict".

40 See. no. 1 of article 3 of Law no. 21/2007, of 12 June (criminal); point b) of no. 2 of article 3 of Dispatch 18778/2007 (family), point 4 of Agreement Protocol (labour).

41 Mariana França Gouveia, Curso de Resolução ..., p. 64. 
order for the mediation process to be effective, it is necessary for the parties to be dynamically involved in the solution of the problem, which is only possible after the interests of each party have been shared ${ }^{42}$.

The requirement of this confidentiality is also evident in the mediation that takes place in the Justice of the Peace Courts, in labour mediation ${ }^{43}$, in family mediation ${ }^{44}$, in criminal mediation ${ }^{45}$, in the European Code of Conduct for Mediators ${ }^{46}$ and in the Directive on mediation ${ }^{47}$, so its essentiality in the mediation process is undeniably expressed.

This confidentiality, which must be respected by both the mediator ${ }^{48}$ and the parties, is not absolute. Deviations are foreseen in the case of compelling reasons of public order, in particular to ensure the protection of the best interests of the child, or when protecting the physical or psychological integrity of a person is at stake.

The enumeration of cases which derogate from the principle of confidentiality is not exhaustive, and this principle may decline whenever rights or interests whose protection is greater than those protected by the principle are involved, i.e. the success of mediation ${ }^{49}$. The principle of confidentiality may also be disregarded when this is necessary for the purpose of implementing the agreement reached, but only in so far as it is particularly necessary to protect the interests ${ }^{50}$. Finally, a third cause for deviating from the principle of confidentiality of the agreement would be the very will of the parties being mediated. It makes sense that a process of a voluntary nature characterized by its flexibility allows the mediated parties to waive the principle of confidentiality, being allowed to use all the information obtained during the procedure. However, a different question is to know the effect of this negotiating declaration of the parties towards the mediator. At this point, we agree with Dulce Lopes and Afonso Patrão's understanding that such a declaration between the mediated parties does not oblige nor can it force the mediator to disregard confidentiality,

42 Dulce Lopes, Afonso Patrão, Lei da Mediação Comentada... pp. 36-37.

43 See no. 2 of Article 24 of the Manual of Procedures and Good Practices of the Labour Mediation System available at (2017.11.23): http://www.dgpj.mj.pt/sections/gral/mediacao-publica/mediacao-anexos/manual-de-boaspraticas/downloadFile/file/SML_Manuel_boas_praticas.pdf?nocache=1351089425.34

44 See Article 2 of Dispatch 18778/2007, which establishes that the FMS conducts its activity while guaranteeing voluntariness, celerity, proximity, flexibility and confidentiality.

45 No. 5 of Article 4 of Law 20/2007 of 12 June on criminal mediation expressly provides that the content of mediation sessions is confidential and cannot be assessed as evidence in court proceedings.

46 Point 3.1 of the European Code of Conduct for Mediators.

47 Article 7 of Directive 2008/52/EC of 21 May 2008 on certain aspects of civil and commercial mediation. him, May pean Qualifications Frsame way in the Spanish legal system onclude have of himve known him, May pean Qualifications Fr

48 Article 28 of the Mediation Law specifically states that the conflict mediator cannot be a witness, expert or agent in any case related to the subject of the mediation procedure.

49 Dulce Lopes, Afonso Patrão, Lei da Mediação Comentada... pp. 49 and following.

50 See no. 3 of article 5 of the Mediation Law. 
thus jeopardizing another principle as or more important than that one , the independence of the mediator ${ }^{51}$.

Indeed, it is our understanding that the mediator will have the independent conduction of the conflict compromised in view of the possibility of being a witness in a process, since one thing is to remain impartial as a conflict mediator and a very different thing is to answer questions involving his perception and judgement of the mediation procedure as a witness in a judicial context ${ }^{52}$.

The legislator does not mention in the law who will be the person/entity with authority to decide about the verification of the assumptions for lifting confidentiality, and it is agreed that the doctrine states that such authority lies with the mediator ${ }^{53}$. However, in our opinion this option does not seem to be the right one. It is true that the mediator does not belong to any professional association, as it happens in the case of lawyers, who can verify the existence of the assumptions to carry out the lifting of professional secrecy ${ }^{54}$. However, it is very similar to the need for such a requirement in the field of law, in order to guarantee the impartial and independent performance of the mediator's functions.

Indeed, the parties will have more confidence in the procedure if they have serious assurances that the confidentiality of the case depends not only on the mediator's interpretation but also on objective criteria to be interpreted by a third party. Moreover, the civil responsibility of the mediator does not satisfy either Greeks or Trojans. On the one hand, the mediated parties do not use an alternative means of settling disputes with the guarantee that they can start another judicial procedure to hold the mediator liable in case of breach of the duty of confidentiality. On the other hand, it is clear that the mediator has much to gain and little to lose by risking an interpretation on the deviation of the principle of confidentiality by being subject to possible repercussions on civil and criminal liability. In view of the fact that the deviation from the principle of confidentiality arises from a greater interest than mediation and the mediated parties, it seems more appropriate that such interest be protected by another independent body that may be part of institutional-

51 Dulce Lopes, Afonso Patrão, Lei da Mediação Comentada... pp. 51.

52 With a clearly opposite view, the Spanish legislator, specifically in point a) of no. 2 of Article 9 of Law 5/2012, of 6 July, about mediation in civil and commercial matters, states that the parties can dispense with express and written agreement the obligation of the mediator's confidentiality. This was also the understanding set out in Article 7 of Directive 2008/52/EC of 21 May 2008.

53 Mariana França Gouveia, Curso de Resolução ..., p. 85; Dulce Lopes, Afonso Patrão, Lei da Mediação Comentada... pp. 52 and following.

54 Article 92 of the Statute of the Lawyers Association. 
ized mediation, whether public or private, thus safeguarding the mediator's position and independence ${ }^{55}$.

Infringement of the principle of confidentiality may have a number of consequences in view of the offending agent and the use made of the information obtained. Firstly, information obtained in breach of the confidentiality principle that is not covered by any of the above exceptions, cannot be assessed in a court or arbitral entity, which will safeguard the position of the mediated party that might be affected by this behaviour. Secondly, with respect to the mediator, such behaviour may give rise to the corresponding civil liability and other sanctions and even penal measures may be applied for infringing secrecy ${ }^{56}$.

The confidentiality of the mediation process also constitutes an essential difference with the principle of publicity that prevails in judicial bodies pursuant to Article 206 of the CRP and that makes alternative means of settling disputes more appealing. This will be the case, for example, of disputes where one of the parties has no interest in disclosing the outcome of the conflict in order to prevent third parties in similar situations from being encouraged to claim their rights by securing a precedent favourable decision. In addition, if mediation is not successful, the mediator will not have any other connection with the resolution of the dispute, which prevents that information from having any influence on the outcome of the dispute. As will be seen, this is no longer the case in the case of conciliation.

\section{c) Principle of equality and impartiality}

The principle of equality and impartiality enshrined in Article 6 of the Mediation Law requires the parties to be treated fairly throughout the mediation process, and the dispute mediator must manage the procedure in such a way as to ensure the balance of powers and the possibility of both parties participating in it. In our view, the application of this principle necessarily requires respect for the audi alteram partem principle, which, although not specifically enshrined in the diploma, is a mandatory consequence of ensuring equal treatment ${ }^{57}$. However, the equality postulated in this area will always be tempered by the mediator's criterion, which, given the specific characteristics of the conflict and the power

55 Dulce Lopes, Afonso Patrão, Lei da Mediação Comentada... p. 52, states that there would even be a duty of the mediator to breach confidentiality which could, in case of omission, cause the mediator to incur in a crime of omission of aid. As we have said, for us this position is very rigid and inadequate to safeguard the interests at stake. The courts will find it very difficult to prove the illegitimacy of a possible omission of aid in this area by the mediator and the mediator will find it very difficult to assume a position of breach of confidentiality without any support that jeopardizes his functions

56 See no. 2 of Article 8 regarding public mediation and article 44, both of the Mediation Law and Article 195 of the Criminal Code.

57 This is also the understanding of Enrique César Pérez -Luño Robledo, “La mediación como Proceso?", pp. 47 and following. 
of each of the mediated parties, should lead to mediation in order to ensure an adequate balance that can compensate for differences of power between the mediated parties.

In short, this principle is intended to ensure the transparency of the mediation procedure so that the parties have full confidence in the process inf which they become an active part, obtaining and reading information, expressing their opinions and cooperating in the definition of the terms of the agreement to be concluded. If, on the other hand, the mediator finds that there is a situation of difference in power between the parties that hampers the resolution of the conflict in compliance with the principle of equality, he may and should, if he deems it appropriate, terminate the mediation procedure as provided for in c) of article 19 of the Mediation Law. The mediator has the duty to balance the forces by suggesting that the parties request the opinion or intervention of specialized technicians in a given subject when this proves necessary or useful to the clarification and well-being of the parties ${ }^{58}$.

The impartiality of the mediator in the context of the mediation procedure is appreciably different from the impartiality required from the judge, insofar as, as a general rule, the mediator is not aware of the dispute to be mediated, understanding it only in the first mediation or pre-mediation session, so he will have a more open mind. The observance of this principle, besides being a duty, also stems from the regime of impediments and excuse of the mediator that the law consecrates ${ }^{59}$. The impartiality of the mediator must be present before, during and after the conclusion of the mediation process. The mediator must not accept mediation when he considers that there is a motive that prevents the performance of his function in accordance with this principle. The mediator must also excuse himself from the function when, during the course of the mediation, he notices the emergence of some reason that affects his impartiality. Finally, the mediator must refrain from advising any of the mediated parties after the conclusion of the mediation procedure ${ }^{60}$.

\section{d) Principle of independence}

In the performance of his duties, the mediator must guide his conduct with independence, free from any pressure whatsoever, whether resulting from his own interests, personal values or external influences. Thus, when the mediator considers that due to legal, ethical

58 See point g) of Article 26 of the Mediation Law.

59 See point f) of Article 26 and Articles 27 and 28 of the Mediation Law.

60 See Article 28 of the Mediation Law. In effect, this precept prohibits the mediator from representing any of the mediated parties, in any related cause, even if indirectly, in the mediated conflict. Indeed, it seems difficult to imagine how the mediator can be a representative of one of the mediated parties in a given process, which, although he has nothing to do materially with the mediated process, cannot be indirectly related, raising reasonable suspicions about the partiality or interest of the mediator. 
or deontological reasons, his independence, impartiality or exemption may be compromised, he should not accept his appointment as a mediator of conflicts, and if he has already initiated the procedure, he must interrupt it and ask to be taken away as soon as he realizes that his independence is or may be affected ${ }^{61}$. Examples of situations that may harm the mediator's impartiality are the personal or professional relationship that he may have with one of the parties or the existence of a direct or indirect financial interest in the outcome of mediation ${ }^{62}$.

The principle of independence is not confused with the principle of impartiality, as the latter requires neutral treatment of the mediation and object of mediation, and the former focuses on verifying that there is no mediator's links that might compromise his or her function by not by exercising it in full freedom, whether these links are exogenous, subordinated to or the influence of a third party, whether endogenous, like values, personal interests, etc. ${ }^{63}$ On the other hand, the duty of independence is the other side of the coin of the right of the conflict mediator to exercise mediation independently, as provided for in point a) of Article 25 of the Mediation Law.

\section{e) Principle of competence and responsibility}

Article 8 of the Mediation Law does not require any specific training for the exercise of mediation activity. It merely refers that mediators can attend training courses that give them specific theoretical and practical skills, namely a training course for conflict mediators carried out by a training entity certified by the Ministry of Justice. Thus, it follows from this provision that it is not compulsory to attend courses certified in accordance with article 24 of the Mediation Law in order to exercise the profession of mediator, only but for purposes of public mediation ${ }^{64}$. However, as will be seen below, the enforceability of the agreement reached in Mediation is a strong incentive for the parties to the conflict to choose mediation as a form of resolving the conflict in a swift, participatory and definitive manner. It follows that, if such mediation is not conducted by a mediator included on the

61 See Article 7 and no. 3 of Article 27 of the Mediation Act and point 2.1 of the European Code of Conduct for Mediators.

62 See supra, with regard to the principle of impartiality, our assertion when considering that even the provision of services by the mediator to one of the parties once the mediation is concluded may question the impartiality and independence of the mediator. See point 2.1 of the European Code of Conduct for Mediators.

63 In practice, the impartial mediation of a dependent mediator can be verified, and the reverse, an impartial mediation by an independent mediator. Indeed, the combination of partiality and independence generate greater assurance and confidence in the process and in the function of the mediator.

64 This is the conclusion that results from no. 5 of Article 24 (5) of the Mediation Law. 
list of conflict mediators organized by the Ministry of Justice, such an agreement will not be enforceable ${ }^{65}$.

With regard to the responsibility of the mediator, no. 2 of Article 8 of the Mediation Law expressly enshrines the civil liability of the mediator arising from the violation of the duties to which he is subject, both in private and in public mediation systems. At this point, it is necessary to distinguish the mediator's responsibility in the public mediation system, subject to the extracontractual civil liability regime typical of the public law of private mediation systems, where it will be necessary to previously qualify the legal transaction that links the mediator and the mediated parts. Without wishing to delve deeper into this problem, the solution has been based on the concurrence theory, which allows the injured party to support his request in any of the civil liability and consumption theory, in which case contractual civil liability cancels out the extracontractual one ${ }^{66}$. Unlawful acts performed by the mediator in the performance of his or her duties may also constitute an unlawful breach of secrecy under article 195 of the Criminal Code and may also lead to the exclusion of the mediator from the list of mediators of the Directorate General for Justice Policy (DGPJ) for a maximum period of two years ${ }^{67}$.

\section{f) Principle of enforceability}

This principle provided for in Article 9 of the Mediation Law usually gives the mediating agreement an enforceable power, without need for judicial approval. This quality of mediation agreements is an essential feature for their promotion as a means of settling disputes insofar as it provides the mediated parties with a system that ends the conflict by concluding an agreement that has binding effect on the parties and whose compliance may be required by the enforcing party through the executive route. The principle of enforceability enhances the effectiveness of the mediation process by establishing itself as a means of settling disputes that is at the same level in terms of effects between the parties and towards third parties rather than a court decision. By establishing automatic enforceability

65 Thus, in practice, in order to be a mediator in a mediation process in which the broader effects of mediation are intended to be safeguarded, it will be necessary to attend and complete a course, and subsequently be included in the list of mediators of the Ministry of Justice. In Spain, in addition to this initial training, the legislator also imposed compulsory continuing training See Ignacio Gallego Domínguez, La formación del mediador en las normas españolas de mediación", Rafael Cabrera Mercado (Dir.) Pedro M. Quesada López (Coor.), La mediación como método para la resolución de conflictos, Dikinson, Madrid, 2017 pp. 132 and following,

66 Dulce Lopes, Afonso Patrão, Lei da Mediação Comentada... p. 65 and following. The difference in regime is of great relevance inasmuch as the contractual liability is subject to the general limitation period of 20 years as opposed to the extracontractual civil liability, which prescribes within three years, as prescribed in Article 498 of the Civil Code. Another significant difference consists in the presumption of guilt of the debtor, enshrined in no. 1 of Article 799 in the scope of contractual civil liability.

67 See Article 7 of Ministerial Edict no. 344/2013, of 27 November and Article 44 of the Mediation Law. 
of written agreements resulting from mediation, the Portuguese legislation went beyond what was required by the European Mediation Directive, which only states that such agreements could be enforced through a sentence, court decision or other authority act ${ }^{68}$.

In any case, for the executive effectiveness of the agreement obtained through mediation to be automatic, it is necessary to fulfil five requirements, which, as Dulce Pontes and Afonso Patrão refer, are resumed to two: the legality of the agreement and the inclusion of the mediator in a specific list ${ }^{69}$. First of all, the legality of the agreement will be assessed in the light of the possibility of mediating the dispute, i.e. that the dispute is about property or available interests ${ }^{70}$ and that no judicial requirement of the agreement obtained is required by special rule ${ }^{71}$.This legality will also depend on the parties' ability to conclude the agreement in question, to comply with the legal requirements for its implementation, and on the existence of a written and signed agreement whose content does not violate public order ${ }^{72}$. Secondly, it is required that the agreement resulting from the mediation is conducted by a mediator included on the list of conflict mediators organized by the Ministry of Justice ${ }^{73}$. This means that all mediations that meet the legality criteria stated above regardless of whether the mediator is on the Ministry's list or not will be valid. However, the effectiveness of such an agreement will be limited, in particular, in case of default by one of the parties, when the mediator is not on the list of the Ministry of Justice ${ }^{74}$. Notwithstanding the foregoing, the mediated parties may always request the court to ratify the agreement resulting from the mediation. To that end, the parties must make a joint application to any court having jurisdiction in the matter ${ }^{75}$. The intervention of the court aims to ascertain whether the agreement in question relates to a litigation that may be the subject of mediation, the parties' capacity to conclude it, and compliance with the general principles of

68 Article 6 of Directive 2008/52/EC of 21 May 2008 on certain aspects of civil and commercial mediation.

69 Dulce Lopes, Afonso Patrão, Lei da Mediação Comentada... pp. 65-66.

70 See paragraph a) of no. 1 of Article 9 and Article 11 of the Mediation Law. In particular, no. 2 of Article 11 requires that a transaction be entered into on the relevant interests. In turn, the Civil Code defines the transaction as the contract through which the parties prevent or end a dispute as long as they can dispose of those rights and deal with licit deals (see Articles 1248 and 1249 of the Civil Code). Still with regard to cases subject to mediation, see Jorge Morais de Carvalho, "A Consagração legal da mediação ... p. 284 and following.

71 This obligation is foreseen for mediations carried out in the Justice of the Peace Courts, as prescribed in article 56 of Law no. 78/2001, of 13 July in its last edition and for civil suits pursuant to no. 3 of Article 24 of Law 141/2015, of 8 September.

72 See Article 20 of the Mediation Law.

73 See paragraph e) of no. 1 of Article 9 of the Mediation Law.

74 As seen above, this requirement would be related to the principle of jurisdiction provided for in Article 8 of the Mediation Law.

75 See Article 14 of the Mediation Law. 
$\operatorname{law}^{76}$, whose relevance materializes in the formation of a much more solid executive title that does not allow an opposition as comprehensive as other executive titles ${ }^{77}$.

Lastly, mediation agreements concluded in another Member State will benefit from the application of the same regime as Article 14 of the Mediation Law, provided that they comply with the principles and rules of the legal system of that Member State, as provided for in Article 15 of the same legal document.

\section{Cases eligible for mediation}

As can be inferred from the above, not all matters liable to create conflict are susceptible to mediation. However, although it is true that initially a stricter position of cases eligible for mediation was postulated, currently there is a fairly widespread acceptance of mediation in areas traditionally closed to such as criminal, labour, fiscal and administrative matters ${ }^{78}$.

Currently, the possibility of mediating a conflict will depend on the type of mediation in question because, as seen above, in the case of criminal mediation ${ }^{79}$, labour mediation ${ }^{80}$,

76 No. 3 of Article 14 expressly indicates the need to verify compliance with the principle of good faith, if the agreement constituted a possible abuse of rights and its content does not infringe the public order. It seems to us, in this case, that there is no justification for imposing different conditions for the same reality.

In fact, whenever possible, the agreement reached in the context of a mediation directed by a registered mediator will be feasible and the mediator must verify only the requirements set forth in point c) of Article 26 of the Mediation Law, i.e., in addition to the aforementioned eligibility for mediation, legitimacy of the parties to intervene in the agreement and the balance of forces of the mediated parties. On the other hand, if it is the court that has such executive power to enforce this executive force, it must go beyond this and attempt to assess such subjective and dynamic realities as those relating to abuse of the right to respect the principle of good faith. On these concepts, see António Menezes Cordeiro, "Do abuso de direito estado das questões e prespectivas", in Ars iudicandi - Estudos em Homenagem ao Prof. Doutor António Castanheira Neves, Vol. II, Coimbra Editora, Coimbra, 2008, pp. 125-176, who states "The abuse of the law and the good faith underlying it represent, (...) a valve of the system: they allow to correct solutions that would otherwise be contrary to elementary vectors"; Mariana França Gouveia, Curso de Resolução ..., p. 81 and following, argues that it will be very difficult for the judge to determine whether or not a mediation agreement violates a mandatory rule on the ground that no evidence is produced in the mediation procedure; Dulce Lopes, Afonso Patrão, Lei da Mediação Comentada... p.72; on the contrary, Jorge Morais de Carvalho, "A Consagração legal da mediação ... p. 289 takes the view that "the control by the judge cannot be limited to compliance with public order".

77 Indeed, opposition based on a judgment as an enforcement order can only be carried out under the terms of article 729 of the Civil Procedure Code.

78 See above mediation systems and Decree-Law no. 10/2011, of 20 January, in the use of the legislative authorization granted by article 124 of Law no. 3-B/2010, of 28 April, in the version introduced by articles 228 and 229 of Law 66-B/2012, of 31 December, which established the Legal Regime of Tax Arbitration.

79 Article 2 of Law 21/2007 of 12 June, which establishes that private and semi-public crimes can be mediated, then imposing some exceptions.

80 See no. 1 of Clause 1 of the Protocol ... which makes the eligibility of the conflict for mediation dependent on the availability of the interest in question, expressly excluding situations resulting from an accident at work. The SML website contains a few examples of some situations that would be included in labour mediation, such as the payment of credits due to the termination of work, change of work place, disciplinary procedures (2017.11.23) http://www.dgpj.mj.pt/sections/gral/mediacao-publica/mediacao-anexos/perguntas-requentes7583/ 
family mediation ${ }^{81}$ and administrative and tax mediation ${ }^{82}$, the widely matters that can be mediated are amply regulated. As far as civil and commercial mediation is concerned, as it is more comprehensive, the criterion delimiting its material scope will result from the conjugation of the principle of ownership and the availability of the rights in question ${ }^{83}$.

Ownership refers to the susceptibility of the pecuniary evaluation of the interest that is the object of conflict between the mediated parties. Thus, whenever we are faced with an interest that can be translated into an economic value, we would be dealing with a matter that can be mediated. In cases where it is not possible to apply the ownership criterion, there is still the possibility, as in voluntary arbitration and in the civil procedure itself, of applying the criterion of the availability of the law that is extended to the possibility of being object of a transaction under the terms of the Article 1249 of the Civil Code ${ }^{84}$.

\section{The mediation procedure}

Knowing that the mediation procedure, albeit structured, is characterized by its great flexibility, closeness and informality, it is important to identify the main stages in which the process is divided ${ }^{85}$. Thus, we can identify the following stages in a mediation procedure:

Hearing of the parties - in the context of pre-mediation, the mediator informs the participants about the procedure, clarifying theirs doubts and then encouraging the signing of the mediation protocol with the legally required requirements ${ }^{86}$. Once the mediation itself has started, the mediator will try, by actively listening to the statements of the parties, to understand what the interests underlying the dispute in question are.

Joint discussion - at this point the parties will present the arguments that support and refute their positions and the mediator must make the parties understand the interests involved in order to open the necessary communication and understanding channels.

81 See Article 4 of Dispatch no. 18778/2007, listing, among other matters, the regulation of parental responsibilities, the use of surname, family house, divorce and separation of assets, allocation and alteration of alimony etc.

82 See Decree-Law no. 10/2011, of 20 January, Edict no. 112-A2011, of 22 March and Article 4 of the New Administrative Arbitration Regulation, available at (2017.11.23) (2017.11.23) https://www.caad.org.pt/files/documentos/CAAD_AANovo_Regulamento_Arbitragem_Administrativa-2015-09-01.pdf

83 Article 11 of the Mediation Law

84 This provision prescribes that the parties cannot compromise on rights that they are not allowed to dispose of, nor on matters relating to illegal business.

85 On the various stages of the mediation process, see Dulce Lopes, Afonso Patrão, Lei da Mediação Comentada... pp. 148 and following; Mariana França Gouveia, Curso de Resolução ..., p. 62 and following, and Enrique César Pérez -Luño Robledo, "La mediación como Proceso? ...", pp. 47 and following, among others. Point a) of no. 1 of Article 591 of the Civil Procedure Code (CPC).

86 See Article 16 of the Mediation Law, including, among other things, the consent of the parties, acceptance of confidentiality, written form, rules of procedure, etc. 
At this stage, it is a matter of making the parties accept that eventually they will not be right about everything.

Establishing the matters in dispute - at this point, the mediator must separate the relevant issues in dispute by proposing to the mediated parties the matters that must be resolved to fully satisfy their interests. The parties should accept or amend the list of proposed matters in order to feel fully committed to finding active solutions to resolve the dispute. It is intended that both parties will be involved in resolving the problem they share.

Looking for ideas - at this stage the parties must actively participate in proposing possible solutions to solve the relevant issues in dispute. It is important that the mediator is creative and encourages the parties to create a wide range of possibilities, suggesting, if he deems it appropriate, the intervention of a technician who can clarify important points for the search for solutions.

Drawing up an agreement - by this point the mediator must be able to draw up an agreement that will enable the interests of the parties to be met and ensure, as far as possible, the maintenance of social peace. The parties can and should intervene at this point in time so that they feel fully identified and bound to the agreement to be made.

End of mediation - finally, mediation may hopefully end with an agreement that is satisfactory for the parties. Nonetheless, mediation may be concluded without agreement either on the initiative of the parties or upon the mediator's proposal when there is no adequate balance of forces. It should be pointed out that even when it does not end with an agreement, mediation could be successful if it allows the re-establishment of communication between the parties, thus facilitating possible future solutions.

\section{Conciliation}

The conciliation is specifically regulated in Article 594 of the Civil Procedure Code and assumes that the matter in question is within the powers of the parties in the scope of the process that is directed by the judge. In these circumstances, the judge is bound to promote conciliation at both the prior $^{87}$ and the final hearing ${ }^{88}$, and the parties may seek conciliation at any time in the process ${ }^{89}$. In conciliation, the judge must actively engage in obtaining the fairness solution most appropriate to the terms of the litigation, so we will always be in the domain of a legal evaluation of the dispute, unlike what happens in mediation, where 
the resolution of the dispute is centred in the interests of the parties. In conciliation, the judge would make a preliminary assessment of the grounds of each party, warning about the weaknesses of each of the claims, predicting a possible outcome and proposing, consequently, the terms of an agreement to settle the dispute.

Once conciliation has been attempted and deemed not possible, in whole or in part, the specific solutions suggested by the judge and the grounds which, in the opinion of the parties, justify the continuation of the dispute, should be recorded in the minutes. At this point we also have a major difference between conciliation and the mediation procedure, where the parties, at any time in the process and without the obligation to justify it, may withdraw from it or refuse the agreement reached ${ }^{90}$.

Conciliation is also possible to be conducted at the Justice of the Peace Courts ${ }^{91}$ and also applies to arbitration, sharing the common characteristic with that held in state courts, i.e. it is conducted by a third party who has decision-making power in the matter ${ }^{92}$.This quality of the third party is decisive because, as is clear from the Mediation Directive, attempts made by the court or the judge to settle a dispute in the context of the legal proceedings relating to the dispute in question will not be considered as mediations, nor in cases when the court or the judge of the case requests the aid or the opinion of an expert ${ }^{93}$. However, it may be considered mediation when the mediator is a judge who has no decision power in the case.

A characteristic of conciliation is that the third party who attempts the rapprochement between the disputing parties has an interest, albeit an indirect one, in resolving the dispute in that it will entail closing another case without having to spend time and efforts performing all the legally required procedures.

This third judge, having the power to decide, may influence, albeit involuntarily, the freedom of the parties in that they are given a forecast of the possible outcome of the process $^{94}$. Moreover, although it is not impossible, it will be difficult for the judge to propose an

90 See no. 4 of Article 594 of CPC as opposed to paragraphs 2 and 3 of Article 4 of the Mediation Law.

91 See no. 1 of Article 26 of Law 78/2001.

92 With regard to arbitration, no. 4 of Article 39 and Article 41 of Law 63/2011, of 14 December, provide for the execution of a transaction between the parties that has been understood in the sense that the arbitrator can carry out the conciliation, but in this case it must count on the consent of the parties.

93 Statement 12 and Article 3 of Directive 2008/52/EC of 21 May 2008. As Mariana França Gouveia, Curso de Resolução ..., p. 88 states, one of the justifications of this exclusion is the impossibility of applying the principle of confidentiality to this type of mediations.

94 In Spanish doctrine, other differences are pointed out, as stated by José Martín Ostos, Introducción al Derecho Procesal, Astigi, Seville 7th Ed., 2016, pp. 104 and following. "unlike the classic conciliation in which the conciliator adopts a passive attitude, in mediation the solution of a conflict between parties is entrusted to latter and to the mediator"; or Javier Alés Sioli, Juan Diego Mata Chacón, Manual Práctico para Mediadores. El misterio de la mediación. Como gestionar un conflicto desde sus cenizas., Atelier, Barcelona, 2016, p. 107, "the conciliator does not intervene in the solution, but rather tells them to do so and if not, he draws up a document declaring the non-existence of compromise. While the 
agreement to the parties for a fairer settlement of the dispute, when the parties themselves defend their positions without addressing the interests that are at their basis and without having produced proof.

It follows from the above that the distinction between conciliation and mediation is based not only on the different capacity of the third party involved in the resolution of the conflict but also on the different objectives pursued by the procedure itself, on the different levels of stakeholder participation and finally, the lack of concern about the future relationship between the parties to the conflict.

\section{Final considerations}

The promotion of mediation in Portugal underwent a major advance due to the effort of the legislator to positivize the principles and basic rules that should characterize this type of procedure, attributing the desirable degree of legal certainty and safety to its development. However, it is true that the spread of mediation as a suitable means of settling disputes is the result of a greater effort by the State, mediation centres, universities, lawyers, and other agents near the public in order to unveil the natural, but unjustified fears about mediation.

Mediation is not a substitute for ordinary jurisdiction, but it is also not subservient to it, and a definitive decision with executive power can be obtained by resorting to it, enabling solving the problem of the parties in a inexpensive, participatory, swift and effective way. The main inconvenience that can be attributed to mediation is related to the possible bureaucracy, because if it is frustrated, it will always be needed to resort to court. However, this constraint seems to be insignificant in relation to the potential benefits of mediation, especially in view of the suspension of the limitation and expiry periods that occurs with the start of mediation.

In mediation, the mediator is the main protagonist, but his role must be invisible, which allows the parties to dominate the course of the procedure by actively collaborating in solving their problems and deciding jointly to choose the best possible solution in order to satisfy their interests. This prevents the frustration of being on the verge of obtaining a decision from a third party who may not have realized what conflicting interests lie behind the dispute.

mediator, as an impartial third party, designs the process together with the parties and with it (...) there is a monitoring phase of the process that the conciliator does not do, being a mere passive intervener". As we have seen, in Portuguese law the active intervention of the judge is required, but in practice, this intervention is generally shallow, simplistic and very directed. 
The professional practice of mediation requires the observance of several principles and the fulfilment of multiple duties, such as impartiality, independence, competence and responsibility that broadly guarantee the legal certainty of the procedure, granting the agreement obtained executive nature, without prejudice to its legal homologation.

Currently, citizens can use mediation to solve a wide range of issues related to their daily lives. As we have seen, the possibility of using mediation is associated with ownership and availability of the rights concerned, without prejudice to the specific regimes in others areas such as labour, criminal law, family law, administrative law, tax law, etc. Thus, in our opinion, resorting to the judiciary, which is more time-consuming, formal and demanding, should only be considered as a complement, thus efficiently managing public and private resources, without neglecting the protection of the interests involved.

Finally, it seems to us that the publication and dissemination of adequate statistical information by mediation centres is an essential tool to demonstrate the beneficial effects attributed to mediation ${ }^{95}$. As a result, it is desirable to provide information on the average duration of mediation procedures in time and number of meetings, the relationship between the sacrifice and benefit of the parties compared with the positions initially adopted, the level of satisfaction of the parties, the cost of mediation and monitoring, after one or two years of compliance with any agreement reached. All these items imply the demanding task of collecting and processing information but they form the foundations that will allow a solid and stable construction of the mediation edifice, showing its advantages for the general population and for legal professionals, whether lawyers, jurists, judges, etc.

95 Jordi Nieva-Fenoll, “Mediación y Arbitraje: Una ilusión decepcionante?”, Rafael Cabrera Mercado (Dir.) Pedro M. Quesada López (Coor.), La mediación como método para la resolución de conflictos, Dikinson, Madrid, 2017, pp. 23 and following state that "reliable statistics about the success of mediation are difficult to obtain because they are partial, insufficient in terms of data or apparently biased". 
COMENTÁRIOS
DE LEGISLAÇÃO
E JURISPRUDÊNCIA
COMMENTS ON LEGISLATION
AND JURISPRUDENCE

COMENTARIOS
DE LEGISLACAOAOA
COMMENTS ON LEGISLATION
AND JURISPRUDENCE

COMENTARIOS
DE LEGISLACAOAOA
COMMENTS ON LEGISLATION
AND JURISPRUDENCE

\section{AND JURISPRUDE - \\ (n)

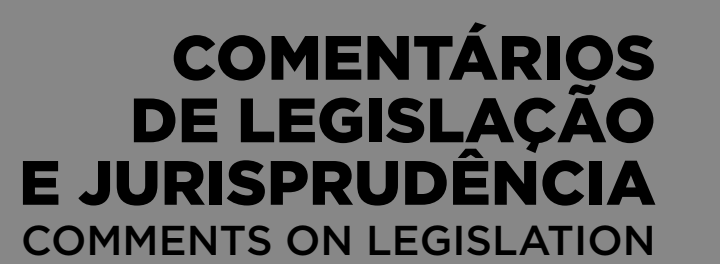

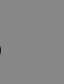

COMENTÁRIOS
DE LEGISLAÇÄO
E JURISPRUDÊACIA
COMMENTS ON LEGISLATION
AND JURISPRUDENCE

.

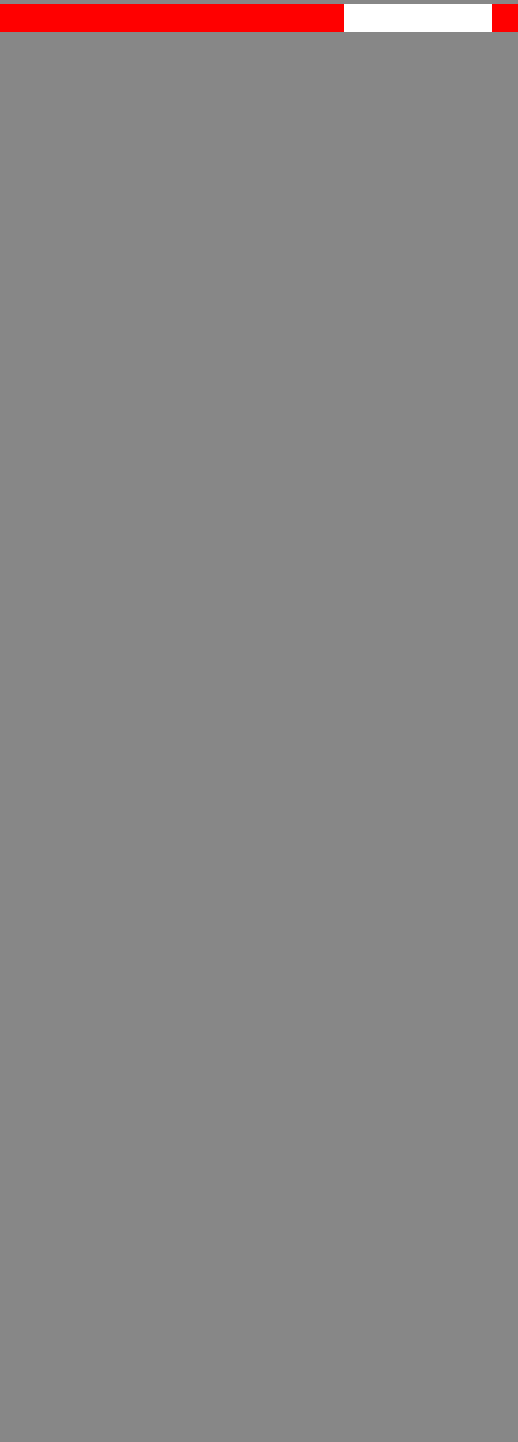

.

.

.

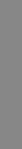
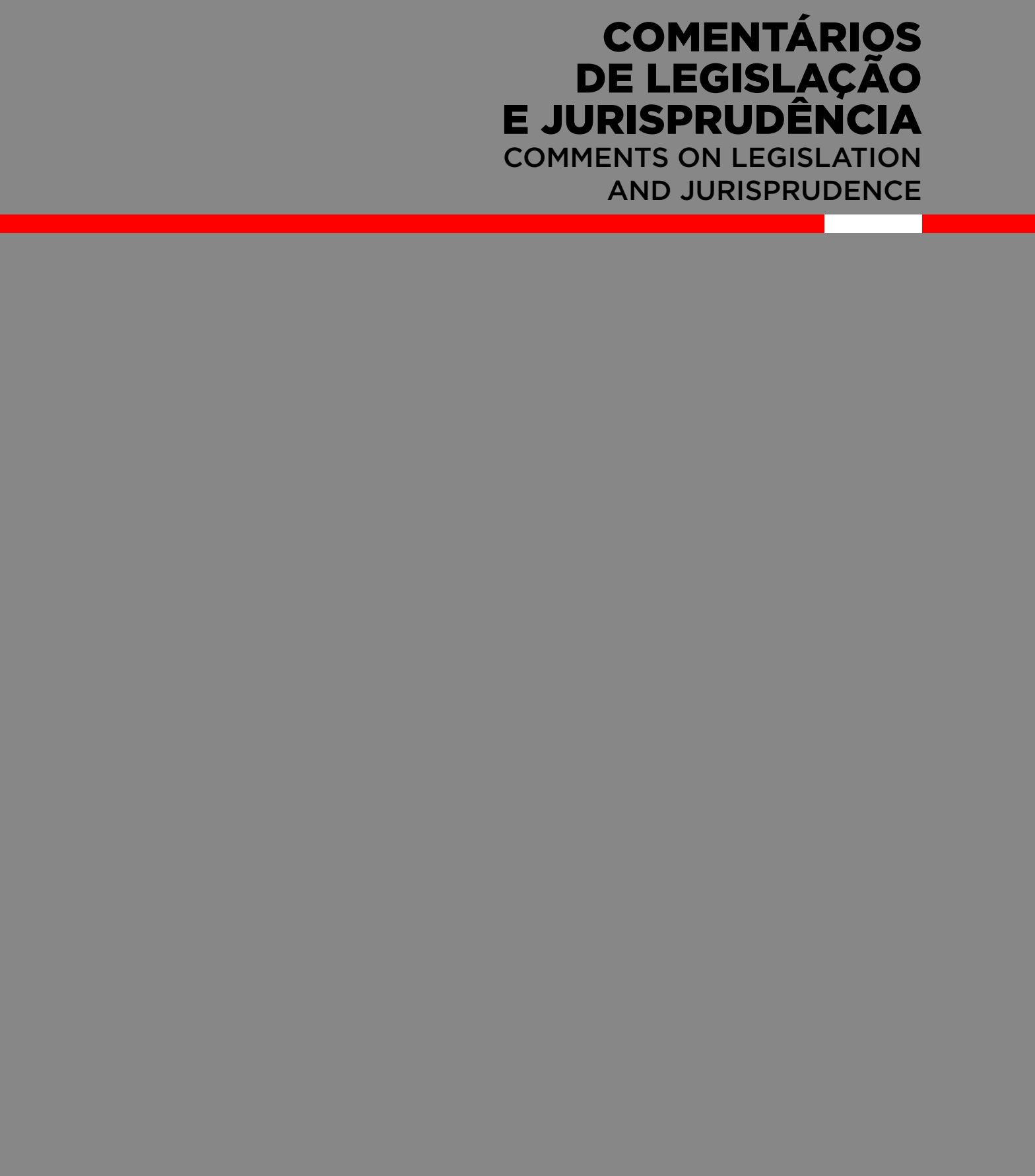

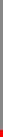




\title{
Comentário à jurisprudência do Superior Tribunal Federal brasileiro sobre início de cumprimento da pena após acórdão condenatório em $2 .^{a}$ instância (Habeas Corpus n..$^{\circ}$ 126.292/SP) ${ }^{1}$
}

\author{
Comment on the jurisprudence of the Brazilian Supreme Federal \\ Court on the start of the sentence following conviction in the \\ 2nd instance (Habeas Corpus No. 126.292/SP)
}

MAXWELL SILVA LAPA ${ }^{2}$

GALILEU - REVISTA DE DIREITO E ECONOMIA - e-ISSN 2184-1845

Volume XIX $\cdot 1^{\text {st }}$ July Julho - 31 ${ }^{\text {TH }}$ December Dezembro $2018 \cdot$ pp. 155-159

DOI: https://doi.org/10.26619/2184-1845.XIX.2.7

Submitted on December $5^{\text {th }}, \mathbf{2 0 1 8} \cdot$ Accepted on ????

Submetido em 5 de Dezembro, 2018 . Aceite a ????

\section{Introdução}

Em 17 de Fevereiro de 2016, o Superior Tribunal de Federal brasileiro (STF) alterou radicalmente jurisprudência alí criada sobre o entendimento de norma constitucional, mais especificadamente, o artigo $5 .^{\circ}$, Inciso LVII da Constituição do Brasil, que estatui que "ninguém será considerado culpado até o trânsito em julgado de sentença penal condenatória". O entendimento jurisprudencial até então vigente ia no sentido da literalidade do texto normativo constitucional firmado pelo Habeas Corpus n. ${ }^{\circ}$ 84.078/MG de 2010 ${ }^{3}$, isto é, o arguido que fosse condenado em primeira instância, sendo considerado inocente pelo princípio da presunção de inocência, não podia dar início ao cumprimento de pena até findo todos os recursos cabíveis. Isto veio a mudar com o HC 126.292/SP de 2016 que deu interpretação diversa, entendendo que o início do cumprimento de pena a partir de acórdão firmado em sede de apelação não colide com o princípio da presunção de inocência firmado pelo artigo $5 .^{\circ}$, Inciso LVII da Constituição brasileira.

1 SUPERIOR TRIBUNAL DE FEDERAL. HC 126.292/SP. Plen. Rel. Min. Teori Zavascki. Pub. 17.02.2016. Disponível em http://stf.jus.br/portal/inteiroTeor/pesquisarInteiroTeor.asp.

2 Mestre em Direito pela Universidade Autónoma de Lisboa.

3 SUPERIOR TRIBUNAL DE FEDERAL. HC 84.078/MG. Plen. Rel. Min. Eros Grau. Pub. 26.02.2010. Disponível em http://stf.jus.br/portal/inteiroTeor/pesquisarInteiroTeor.asp. 
Esta mudança de entendimento do STF veio a suscitar caloroso debate no meio acadêmico e jurídico que até o momento não se encontra pacificado, havendo aqueles que entendem existir aí uma clara atuação do judiciário no sentido de alterar a norma constitucional num claro ativismo judicial, ultrapassando asssim as suas atribuições constitucionais, bem como existem aqueles com o entendimento de que o cumprimento de pena à partir de decisão em segunda intância não implica em uma violação do princício da presunção de inocência, ao contrário, constitui, isto sim, na eficácia jurídica das leis penais. Sobre esta controversa mudança de entendimento nesta decisão histórica do STF, criando nova jurisprudência, tecerei alguns comentários que pela economia do trabalho a que me proponho não permitirá uma abordagem mais minunciosa e aprofundada sobre o tema, porém concisa e direta.

\section{O princípio da presunção de inocência}

O princípio da presunção de inocência nasce como resposta ao modelo precessual penal de tipo inquisitórial do século XVIII, onde ao acusado cabia fazer prova da sua inocência, cabia-lhe o ônus da prova, ou seja, o acusado é tido como culpado até que se prove inocente. Vencido o modelo absolutista pela corrente iluminista, surge um novo modelo de processo penal, o de tipo acusatorial, onde o acusado é tido como inocente até prova em contrário, cabendo a quem acusa fazer prova da culpa.

O princípio da presunção de inocência é consagrado pela primeira vez na Declaração dos Direitos do Homem e do Cidadão de 1789 no seu artigo 9. ${ }^{\circ}$ e a essência do princípio da presunção de inocência, o seu sentido primordial, assenta na ideia da garantia da liberdade individual, funcionando como limite a ação arbitrária do poder judicial e dos seus excessos. ${ }^{4}$

\section{Espírito geral do Acórdão proferido pelo STF sobre o HC 126.292/SP}

Numa mudança de entendimento, o STF, por maioria de sete votos vencedores contra quatro votos vencidos, altera a jurisprudência criada por ele mesmo e até então vigente de não admitir o início do cumprimento de sentença penal condenatória confirmada em sede de apelação para a admissão de início de cumprimento de sentença penal condenatória confirmada em sede de apelação. Nesta mudança de entendimento, quero expor um voto em particular, o voto do ministro Luis Roberto Barroso, pois, pela sua sistematização e con-

4 VALENTE, Manuel Monteiro Guedes - Processo Penal - Tomo I. Coimbra: Almedina, 2010, pp. 159 ss. 
teúdo abordado constituem o espírito norteador do acórdão objeto de comentário e cujos elementos constituidores permeiam os demais votos vencedores.

O voto do ministro Luis Roberto Barroso se estrutura em três partes, porém irei ater-me apenas as duas primeiras partes, porque, em certa medida e devido a economia do trabalho, a terceira parte também está inserida em termos gerais a seguir, onde a primeira parte se enfoca na questão controversa, isto é, na possibilidade do início de cumprimento de pena após acórdão em sede de recurso, para tanto se recorre ao conceito de mutação constitucional, lembrando ao pleno da "oscilação da jurisprudência do STF na matéria", ou seja, de que desde a promulgação da Constituição de 1988 até 2009 o entendimento sobre a matéria era a de que o texto normativo constituicional não impedia a execução da pena após confirmação de sentença condenatória em sede de apelação "ainda que pendentes de julgamento os recursos extraordinário (RE) e especial (Resp.)" com fudamento de que tais recursos possuem efeitos meraramente dovolutivos e não suspensivos, não revendo provas e fatos, mas apenas "eventual inconstitucionalidade ou ilegalidade dos julgados de instâncias inferiores". Contudo, em 2009, o STF mudou seu entendimento sobre a matéria no julgamento do HC 84078/MG e passou a interpretar o dipositivo constitucional na sua literalidade, ou seja, não há execução de pena após acórdão em sede de apelação, pois a literalidade do texto normativo constitucional "engloba todas as fases processuais, inclusive as de natureza extraordinárias"; esta nova interpretação normativa gerou, segundo Barroso, três consequências danosas: i) infindável interposição de recusrsos protelatórios; ii) aprofundou a seletividade do sistema penal, beneficiando os réus que possuiam maior poder econômico; e iii) agravou o descrédito da sociedade no sistema de justiça penal. Devido a estas três consequências, justifica Barroso, se faz necessária uma interpretação não literal do texto normativo, porém, uma "interpretação mais condizente com as exigências da ordem constitucional no sentido de garantir a efetividade da lei penal".

Já agora, a segunda parte do seu voto tráz um enfoque na fundamentação jurídica cujo eixo principal está na ideia de que a presunção de inocência sendo um princípio e não uma regra deverá ser conjugado com outros valores jurídico-constitucionais, ou seja, a intensidade de aplicação do referido princípio poderá ser maior ou menor; no caso em questão, diz Barroso, está em conjugação "dois grupos de normas constitucionais colidentes": o princípio da presunção de inocência e o interesse da efetividade do sistema penal que está em estreita ligação com a exigênca de ordem pública para assegurar a credibilidade do sistema penal; assim sendo, para o ministro, de um lado, enquanto o princípio da presunção de inocência perde sua força à medida que o processo avança, por outro lado, o interesse constitucional da efetividade das leis penais ganha maior força, alcançando seu alge na prolação 
de acórdão em sede de apelação, pois a partir desta instância já não há mais decisões sobre fatos e provas, concluindo assim o ministro: ${ }^{5}$

Portanto, o sacrifício que se impõe ao princípio da não culpabilidade - prisão do acusado condenado em segundo grau antes do trânsito em julgado - é superado pelo que se ganha em proteção da efetividade e da credibilidade da Justiça, sobretudo diante da mínima probabilidade de reforma da condenação (...).

\section{Conclusão}

Concordo com o ministro Barroso quando este evidência as três consequências danosas provocada pelo HC 84078/MG, ou seja, infindável interposição de recusrsos protelatórios, o aprofudamento da seletividade da justiça beneficiando os réus que possuem maior poder econômico e o agravamento do descrédito da sociedade no sistema de justiça penal; contudo, discordo de que para evitar tais consequências a solução seja apelar a chamada mutação constitucional, aceitando uma interpretação oposta da que está no texto constitucional, pois o que se está a fazer, ao fim, é alterar uma norma constitucional, o que o STF está a fazer é, no fundo, legislar, e isto ultrapassa as suas competências, como bem argumentou o ministro Marco Aurélio de Mello em seu voto vencido: ${ }^{6}$

Caminha-se (...) para verdadeira promulgação de emenda constitucional. (...) será proclamado que a clásula reveladora do princípio da não culpabilidade não encerra garantia, porque, antes do trânsito em julgado da decisão condenatória, é possível colocar o réu no xilindró, pouco importando que, posteriormente, o título condenatório venha a ser reformado.

Depois, o ministro Barroso, ao argumentar em seu voto que a presunção de inocência sendo um princípio e não uma regra, deverá ser conjulgado a lúz de outros interesses constitucionais como, por exemplo, o da efetividade do sistema penal para garantir a credibilidade do mesmo, e assim evoluindo em seu argumento, a medida que o processo penal avança, a presunção de inocência diminue e o interesse constitucional da eficácia do sistema penal aumenta, por isso mesmo, sendo necessário sacrificar o primeiro em favor

5 SUPERIOR TRIBUNAL DE FEDERAL. HC 126.292/SP. Plen. Rel. Min. Teori Zavascki. Pub. 17.02.2016. pp. 28 e ss. Disponivel em http://stf.jus.br/portal/inteiroTeor/pesquisarInteiroTeor.asp.

6 SUPERIOR TRIBUNAL DE FEDERAL. HC 126.292/SP. Plen. Rel. Min. Teori Zavascki. Pub. 17.02.2016. p. 78. Disponível em http://stf.jus.br/portal/inteiroTeor/pesquisarInteiroTeor.asp. 
do segundo para garantir a credibilidade da justiça, reforça uma ideia de que o princípio da presunção de inocência não é mais que uma ficção jurídica ${ }^{7}$ com a consequência de que a partir da condenação em sede de apelação o réu passa a ser hipoteticamente inocente e não efetivamente inocente, em outras palavras, o réu, a partir da condenação em segunda instância é de fato culpado e hispoteticamente inocente, isto evidenciando um claro confronto entre o que prescreve o artigo 5 . $^{\mathrm{a}}$, Inciso LVII da Constituição brasileira e o início de cumprimento de pena a partir de condenação em sede de apelação.

Disto isto, não se pode concordar com a solução adotada pelo STF, pois constitui um atalho para uma solução muito mais complexa e que passa necessariamente pelo Congresso Nacional brasileiro, depois, desde a vigência da constituição de 88 até o momento se passaram apenas trinta anos e tivemos três mutações constitucionais nesta matéria e nada garante que em breve não poderá haver outra no sentido oposto da solução de agora adotada, isto será claramente uma situação de insegurança jurídica quanto as soluções dadas pela mais alta corte do país, não sendo nem um pouco salutar para uma sociedade que passa por um momento de grave crise institucional.

\section{REFERÊNCIAS BIBLIOGRÁFICAS}

MOURA, José Souto de - A questão da presunção de inocência do arguido. In Revista do Ministério Público.

Lisboa. ISSN 0870-6107. N. 42, 1990, p. 31-47.

VALENTE, Manuel Monteiro Guedes - Processo Penal - Tomo I. Coimbra: Almedina, 2010.

7 MOURA, José Souto de - A questão da presunção de inocência do arguido. In Revista do Ministério Público. Lisboa. ISSN 0870-6107. N. 42, 1990, pp. 38 ss. 


\title{
Comentário ao Acórdão do Supremo Tribunal de Justiça n. ${ }^{\circ}$ 533/16.7PBSTR.E1.S1 de 19/04/2018
}

\author{
Comment on the Ruling of the Supreme Court of Justice \\ No. 533/16.7PBSTR.E1.S1 of 19/04/2018
}

\section{VANESSA DE BRITO SEQUEIRA' \\ ALFREDO ANDRADE SANTOS ${ }^{2}$}

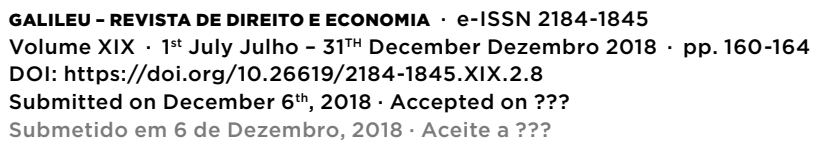

\section{Introdução}

O acórdão que nos propomos analisar, traz-nos à colação um pouco do medo da insegurança jurídica que por vezes acontece no nosso Estado de Direito Democrático, algumas vezes por lapso, outras por incompetência e outras ainda movidas por uma intenção popularista.

Apraz-nos trazer à discussão temas como o homicídio qualificado, que por vezes tantas dúvidas cria no momento de o aplicar, o infanticídio, que aparenta ser bastante desconhecido pelo povo, pois se uma mãe mata o filho, seja em que momento for, aplica-se automaticamente o homicídio qualificado na cultura popular, bem como, explicar um pouco em que assenta o princípio in dubio pro reu, e a forma como este deve ser entendido, para não dar azo a interpretações extensivas do seu conteúdo que só o prejudicariam.

\section{Plano Normativo}

O acórdão em apreço, verte sobre a interpretação do princípio In Dubio Pro Reu, bem como, sobre as normas penais do Homicídio Qualificado (artigo 132. ${ }^{\circ}$ do Código Penal Português) e do Infanticídio (artigo 136. ${ }^{\circ}$ do Código Penal Português).

Embora não possamos efectuar uma análise exaustiva sobre cada um deles, também não podemos demarcar-nos de esclarecer pelo menos de forma abreviada cada um deles, visto que, será oportuno para um melhor entender da crítica efectuada ao acórdão. 
Comecemos então pelo princípio In Dubio Pro Reu, trata-se de um princípio constitucional do estado de direito democrático e que deve enformar todo o processo penal. Neste sentido, tal princípio aparece como que uma imposição ao juiz, de forma a que este decida a favor do arguido, quando não possa ser subtraída a "dúvida razoável", nem se possa dar como provada a veracidade dos factos decisivos para a resolução da causa. Este princípio tem que ser articulado com o princípio da Presunção de Inocência previsto no artigo $32 .^{\circ}$ n. ${ }^{\circ} 2$ da Constituição da República Portuguesa e ainda com o princípio Nulla Poena Sine Culpa, na medida em que, a não observação dos pressupostos de afastamento da "dúvida razoável", nem se possam dar como provados os factos, o juiz decida a favor do arguido, por força da não violação do princípio da culpa. ${ }^{3}$

O Homicídio Qualificado previsto no artigo $132 .^{\circ}$ do Código Penal Português, mais não é do que do que uma forma agravada do tipo de ilícito previsto no artigo $131 .^{\circ}$ do mesmo código (Homicídio Simples), assente nos mesmos termos e pressupostos do facto ilícito, faz depender a qualificação de um critério de culpa agravado, (especial censurabilidade e perversidade), previsto no $n .^{\circ} 1$ do artigo $132 .^{\circ}$ articulado com a técnica de exemplos padrão do . $^{\circ} 2$ do mesmo artigo.

Inspirando-se nos códigos penais suiço e alemão, o legislador português pretendeu não limitar os factos susceptíveis de qualificar o ilícito, bem como as alíneas previstas no n. ${ }^{\circ} 2$ não se entendam de forma taxativa, nem como qualificadores automáticos do tipo de ilícito. Estamos perante uma situação em que está em causa um maior juízo de censura, este juízo é graduável e está refém das condições em que se desenvolveu a conduta. Entende-se por especial censurabilidade, o afastamento da conduta praticada de um padrão normal, com uma exigência superior que aqueles motivos não conduzissem à prática do facto ilícito, ou seja o agente deveria abster-se de praticar o crime. A especial perversidade, assenta numa maior rejeição do comportamento em virtude de esse resultar de pressupostos abjectos. ${ }^{4}$

O Infanticídio previsto pelo artigo $136 .^{\circ}$ do Código Penal Português, é uma forma de privilegiamento do crime de homicídio, na qual está em causa a conduta da mão em provocar a morte do filho, é um crime específico que revela a qualidade do autor ser obrigatoriamente a mãe biológica da vítima. Para que o tipo de ilícito fique preenchido, não basta a mãe matar o filho, esta tem que estar sob uma influência perturbadora provocada pelo parto num hiato temporal que tem que decorrer durante ou logo após o parto. Como

3 Seguindo a linha de pensamento de DIAS, Jorge de Figueiredo - Direito Processual Penal. Reimpressão da $1 .{ }^{a}$ Edição de 1974. Coimbra: Coimbra Editora, 2004, pp. 211 e ss., e CANOTILHO, J.J. Gomes; MOREIRA, Vital - Constituição da República Anotada - Vol. I. 4. ${ }^{a}$ ed. Coimbra: Coimbra Editora, 2014, pp. 518 e ss.

4 DIAS, Jorge de Figueiredo - Comentário Conimbricense do Código Penal - Parte Especial - Tomo I. Coimbra: Coimbra Editora, 1999, pp. 24 e ss., SILVA, Fernando - Direito Penal Especial: Crimes Contra as Pessoas. 3. ${ }^{\mathrm{a}}$ ed. Lisboa: Quid Juris, 2011, pp. 53 e ss. 
Comentário ao Acórdão do Supremo Tribunal de Justiça...

VANESSA DE BRITO SEQUEIRA / ALFREDO ANDRADE SANTOS

é sabido, o parto é por natureza um acontecimento doloroso e violento, pretendeu assim o legislador privilegiar este tipo de ilícito, uma vez que, por vezes pode afectar de tal forma a mãe, chegando mesmo a retirar-lhe o discernimento necessário, impedindo a própria de ter percepção real dos factos, diminuindo-lhe deste modo a culpa. ${ }^{5}$

\section{Factos do Processo}

O referido acórdão versa sobre uma mãe (A), que descobrindo que estava grávida entre Fevereiro e Março de 2016 e não desejando a gravidez, decidiu não revelar a ninguém a sua condição, bem como, ainda passou a ocultá-la, esforçando-se para que esta não perceptível a terceiros, nomeadamente ao seu companheiro e familiares, negando sempre a sua condição de gestante sempre que lhe era questionado, dissimulando assim todo o período de gravidez e recusou durante todo o processo de gestação consultar um médico ginecologista ou obstetra.

Em Junho de 2016, encontrando-se já no termo da gravidez, A sentiu as contracções próprias do parto, saiu de casa sem comunicar a ninguém e escondeu-se numa casa abandonada onde entrou em trabalho de parto e acabou por parir uma criança com vida que teve respiração extra-uterina. A, de forma livre, deliberada e consciente matou a criança, sabendo que a sua conduta era passível de responsabilização penal, no entanto A presumiu que a criança estivesse morta uma vez, que a criança não chorou e não a viu respirar. Após terminar com a vida da criança, ocultou o corpo num primeiro local que viria a alterar passados dois dias para outro local, pretendendo desta forma desfazer-se do corpo, para que este não pudesse ser encontrado, a sua acção foi livre, deliberada e conciente, sabendo a mesma que a sua conduta era criminalmente punível.

\section{Fundamentação do Acórdão}

Toda a matéria de facto acima descrita, foi dada como provada em sede de tribunal. Contudo, quanto à matéria de direito recorrida, sobre a violação do princípio in dubio pro reu, na medida em que, à arguida deveria ser aplicado o crime de infanticídio do artigo $136 .^{\circ}$ do Código Penal Português, ou que mais não fosse, se assim não se entender, deveria ser aplicado um crime de homicídio por negligência, previsto pelo artigo $131 .^{\circ}$ articulado com o artigo $15 .^{\circ}$ e por força do artigo $16 .^{\circ}$ (Erro Sobre as Circunstâncias de Facto) todos do mesmo

5 DIAS, Jorge de Figueiredo - Comentário Conimbricense do Código Penal - Parte Especial - Tomo I. Coimbra: Coimbra Editora, 1999, pp. 100 e ss., SILVA, Fernando - Direito Penal Especial: Crimes Contra as Pessoas. $3 .^{a}$ ed. Lisboa: Quid Juris, 2011, pp. 135 e ss. 
código, uma vez que a agente presumiu que a criança estava morta no acto do nascimento, ou ainda em último dos casos, considera a arguida que não existiram elementos de uma censurabilidade ou perversidade agravada que levem à qualificação, sendo assim punida pelo crime de homicídio simples previsto no artigo $131 .^{\circ}$ do Código Penal Português.

Ora, de toda a prova recolhida, nada obsta à qualificação do homicídio e muito menos que o crime possa ser enquadrado no erro sobre as circunstâncias de facto do artigo $16^{\circ}, \mathrm{o}$ que levou à confirmação da sentença recorrida, imputando o crime de homicídio qualificado à agente.

Enfim, decidiu o Supremo Tribunal de Justiça não ser razoável, que durante todo o processo de investigação não tenho sido realizado um exame pericial afim de concluir se existiu uma influência perturbadora provocada pelo parto e, neste sentido, mantendo a mesma pena aplicada, devolveu o processo nos termos do artigo $426 .^{\circ} \mathrm{n} .{ }^{\circ} 2$ do Código de Processo Penal, para a obtenção de nova prova, mesmo sabendo ser difícil de apurar devido ao hiato temporal que decorreu entretanto, e recomendou que não sendo possível ilidir todas as dúvidas de que não tenha existido uma perturbação durante ou ogo após o parto, deve o tribunal condenar a arguida pelo crime de infanticídio, como se esta o tivesse praticado, por ser este mais favorável à acusada, por força do princípio in dubio pro reu.

\section{Análise Crítica}

Perante toda a fundamentação do acórdão, entendemos corroborar inteiramente com a mesma, uma vez, que nada contradiz a prova produzida que a agente tentou esconder a gravidez, nunca quis ser acompanhada pelo médico ginecologista ou obstetra e quando sentiu as contracções do fim de tempo de gravidez, optou por sair de casa e escondeu-se numa casa abandonada, onde entrou em trabalho de parto e deu à luz uma criança com vida, que teve respiração extra-uterina, acabando por matá-la de seguida, ora, bem sabemos que a qualificação, não depende somente das alíneas estabelecidas no $\mathrm{n} .^{\circ} 2$ do artigo $132 .^{\circ}$ do Código Penal Português, esta tem de ser susceptível de criar uma especial censurabilidade e perversidade, o que a nosso ver se verificou, por força da existência de um lapso temporal suficiente para que a agente se conformasse com a sua condição de grávida e se fosse afastando da ideia de cometer o crime, o que não se veio a verificar, agindo a mesma de forma deliberada livre e consciente.

Quanto à violação do princípio in dubio pro reu, que a agente vem recorrer para que a sua conduta possa antes ser integrada no crime de infanticídio afastando o homicídio qualificado, mais uma vez, vamos de encontro ao acórdão, na medida em que, no caso concreto não existiu violação de tal princípio, pois por lapso da investigação, não existiu um 
qualquer relatório pericial que confirme ou não a influência perturbador do parto, deste modo, o Supremo Tribunal de Justiça fez o que lhe competia, devolvendo assim o processo para que se possa voltar a fazer nova prova sobre a existência de tal perturbação, com uma recomendação, que se não ficarem refutadas as dúvidas quanto à existência da influência perturbadora durante ou logo após o parto, que levou ao desiderato final, deve à arguida ser imputado o crime de infanticídio, tal como se essa influência tivesse existido, por ser mais favorável à agente, resultado então do princípio in dubio pro reu, basilar do Direito Processual Penal e decorrente do princípio da Presunção de Inocência, previsto pelo artigo $32 .^{\circ}$ n. ${ }^{\circ} 2$ da Constituição da República Portuguesa.

\section{Conclusão}

Embora concordemos com a posição adoptada pelo Supremo Tribunal de Justiça, não podemos branquear, que num tempo em que a justiça se pede cada vez mais célere e que estão em causa direitos fundamentais dos cidadãos, uma vez que estamos perante penas privativas da liberdade, é mister da investigação recolher todas as provas relevantes para que possa ser apurada a verdade material, a contrário de se basear em convicções ou presunções que os delitos possam ser cometidos consoante o presumido, e muito menos entrar em popularismos jurídicos, que não querendo ser mal interpretado, nem julgar o todo pela parte, foi o que parece que sucedeu no caso em apreço, pois fruto de uma má investigação, resultou naquilo que aparenta ter sido uma convicção da investigação que estaríamos perante um homicídio qualificado, ou então, pretendeu seguir uma linha de popularismo, que pretende uma condenação de acordo com o pensamento popular, que bem sabemos, na sua maioria é leigo e desfasado da ciência jurídica.

\section{REFERÊNCIAS BIBLIOGRÁFICAS}

CANOTILHO, J.J. Gomes; MOREIRA, Vital - Constituição da República Anotada - Vol. I. 4. ${ }^{a}$ ed. Coimbra: Coimbra Editora, 2014.

DIAS, Jorge de Figueiredo - Comentário Conimbricense do Código Penal - Parte Especial - Tomo I. Coimbra: Coimbra Editora, 1999.

DIAS, Jorge de Figueiredo - Direito Processual Penal. Reimpressão da 1. ${ }^{a}$ Edição de 1974. Coimbra: Coimbra Editora, 2004.

SILVA, Fernando - Direito Penal Especial: Crimes Contra as Pessoas. 3. ${ }^{\mathrm{a}}$ ed. Lisboa: Quid Juris, 2011. 


\section{RECENSÖES
REVIEWS

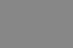
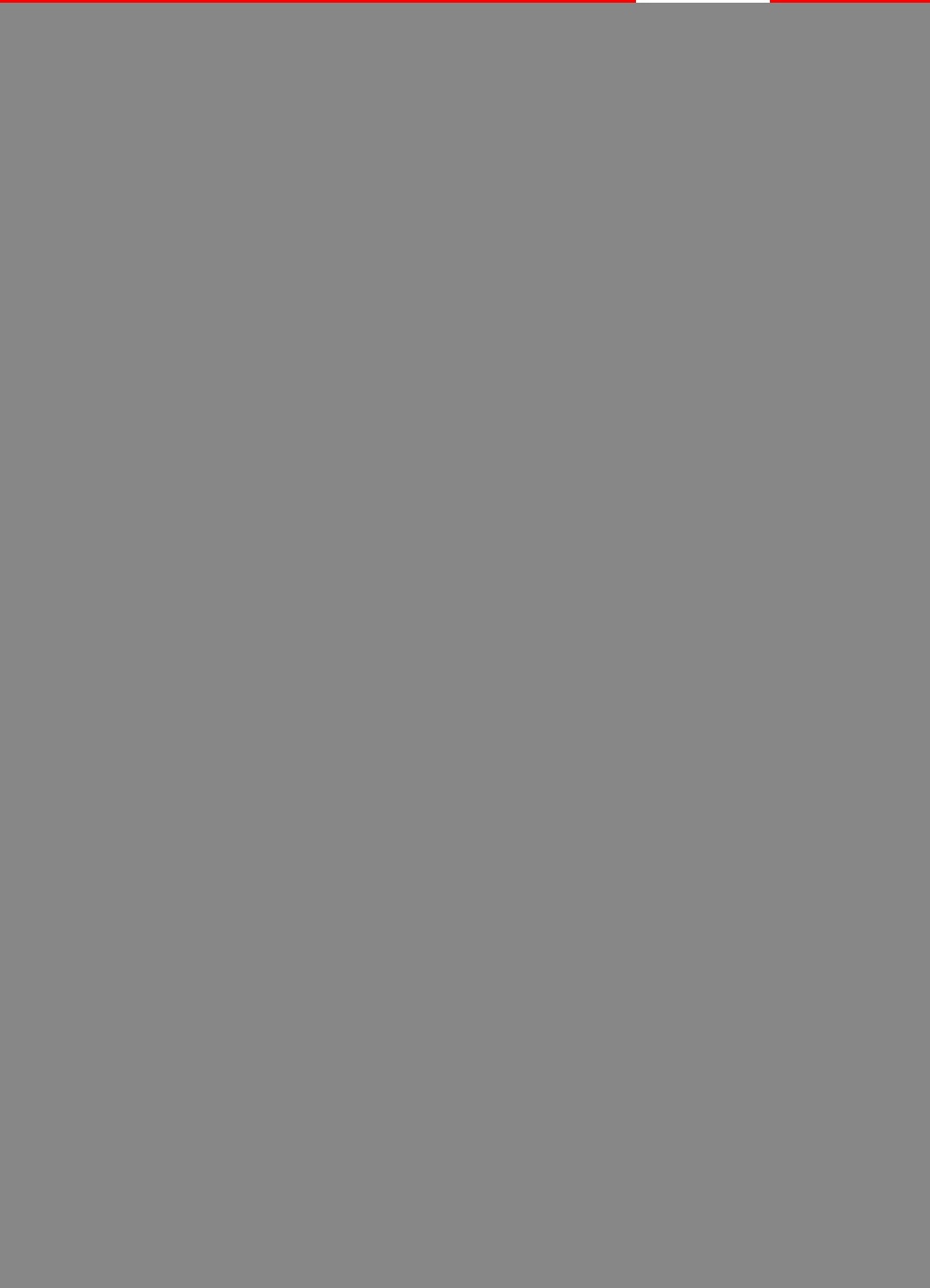

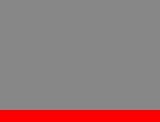

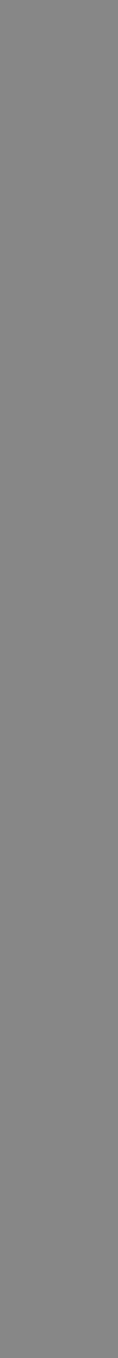




\title{
"OS DESAFIOS DO DIREITO DO SÉCULO XXI", COORDENADA POR MANUEL MONTEIRO GUEDES VALENTE
}

\author{
"THE CHALLENGES OF LAW IN THE $21^{\text {ST }}$ CENTURY", \\ COORDINATED BY MANUEL MONTEIRO GUEDES VALENTE \\ EDITORA ALMEDINA, 2018
}

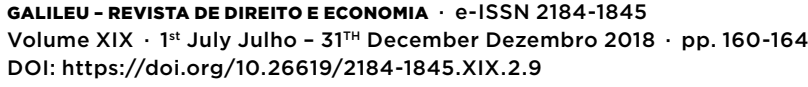

O livro é o segundo de uma promissora linha de investigação que seu coordenador, Manuel Monteiro Guedes Valente, vem desenvolvendo no âmbito do Ratio Legis - Centro de $I \& D$ da Universidade Autónoma de Lisboa, trazendo à discussão temas relativos ao Genoma Humano, Europeísmo, Poder e Política, Constituição e Democracia. Compõe-se de nove artigos escritos por autores de Portugal, Espanha, Itália, Moçambique e Brasil, sumariamente assim dispostos: 1) El reglamento de la Fiscalia Europea y su incidencia en los derechos y garantías procesales (un acercamiento desde el ordenamiento jurídico español), por María Ángeles Pérez Marín; 2) Direito, Genoma e Identidade: desafios, por Stela Barbas; 3) O direito genómico hoje: análise do eugenismo e da dignidade humana centrada no pensamento de Habermas, por Virgílio Serra de Carvalho; 4) Il potere giudiziario e la legge processuale penale in Italia, por Bruna Capparelli; 5) Estado, Poder e Segurança, por Eduardo Pereira Correia; 6) A despesa pública justa, por Maria D'Oliveira Martins; 7) O GRPD, ou Regulamento Geral de Proteção de Dados como exemplo da tendência de um Estado fiscalizador do cumprimento de direitos fundamentais, por Pedro
Trovão do Rosário; 8) Fenomenologia quântica da Constituição: proatividade normativa, pulsar da realidade e mutação, por Rodrigo Lobato Oliveira de Souza; e 9) Normatividade e perspectivas supranacionais, por Nereu José Giacomolli.

A diversidade temática do livro, embora possa parecer ao leitor mais desatento um apanhado caótico de questões desconexas, tem na verdade uma unidade discursiva que se pode reconduzir à preocupação comum de seus autores em buscar respostas jurídicas às diversas mutações sociais, políticas e econômicas que se fazem sentir no âmbito da vida jurídica, cujo coração ainda pulsa a partir da ideia de proteção do homem face às múltiplas possibilidades de submissão arbitrária ao poder sem controle. A leitura de cada artigo, nesse sentido, conduz-nos pelo esforço de cada autor para construir um discurso jurídico segundo novas intituições que emergem do enfrentamento do novo, na dimensão fática do direito, mas não necessariamente implicando uma negação da dimensão valorativa que se tem alimentando da ideia de justiça e orientado por esta que constitui a fonte do humanismo jurídico ocidental. O louvável 
na obra está, portanto, em conseguir identificar na mutação da realidade seus novos problemas que confrontam o direito, embora ainda reafirmando a racionalidade jurídica como uma dimensão irrecusável ao homem, mesmo diante dos problemas que surgem na era da sociedade global, comuncacional e científica.

Os desafios do direito do século XXI se tornam, assim, os desafios do "homo juridicus", como o descreve Alain Supiot na busca pela compreensão simbólica do sentido da vida, do homem que se insurge contra o direito posto, mas que do direito ainda depende até para poder continuar insurigindo-se, já não necessariamente contra a ordem jurídica posta, porque em constante mutação, mas contra a nova ordem que se vai constituindo pelas expressões do poder nas diversas esferas da vida do homem, não apenas como cidadão de um Estado, parte num contrato ou sujeito à persecução penal, mas já agora nas novas e diversas esferas que se vão construindo em torno de sua vida, acrescendo-lhe não apenas novas liberdades como também novas constrições aos direitos fundamentais.

É, assim, que se podem identificar novas dimensões de existência e convivência humana, que questionam o direto no século XXI, desafiando-lhe com problemas que emergem no âmbito do espaço europeu e global, a exigir uma recompreensão das relações entre poder legislativo e judicial, no quadro da representatividade democrática; no âmbito do espaço digital, a exigir uma recompreensão dos direitos fundamentais; no âmbito do espaço científico com os avanços da engenharia genética, a exigir um biodireito capaz de salvar a dignidade humana da vontade excessiva de saber que se pode transmudar muito facilmente em uma nova vontade de poder, que nos abrirá não para um novo iluminismo, como o descreve Steven Pinker, mas para uma nova idade média assombrada pelos avanços da tecnologias.

O livro, é certo, não esgota todas as questões jurídicas que têm desafiado o direito do século XXI, mas a considerar que se trata do segundo de uma linha de investigação, esperamos que outros se sigam e persistam desvendando os novos espaços jurídicos, ampliando nossa percepção do direito e nosso crescimento como homem jurídico. É este o contributo da obra que merece ser lida e discutida no espaço da Universidade, para a qual devem convergir as questões que interessam ao homem do século XXI.

\section{ELIOMAR DA SILVA PEREIRA}

Doutor em Direito pela Universidade Católica Portuguesa

Professor e Coordenador do Programa de Pós-Graduação da Escola Superior de Polícia (Polícia Federal do Brasil) 
"NOVOS ESTUDOS SOBRE LIBERDADE RELIGIOSA, RISCO E SEGURANÇA NO SÉCULO XXI" COORDENAÇÃO: DAVIDE ARGIOLAS

\author{
"NEW STUDIES ON RELIGIOUS FREEDOM, RISK AND SECURITY IN THE 21ST \\ CENTURY". COORDINATION: DAVIDE ARGIOLAS \\ EDITORA PETRONY, 2018.
}

\begin{abstract}
GALILEU - REVISTA DE DIREITO E ECONOMIA · e-ISSN 2184-1845
Volume XIX $\cdot 1^{\text {st }}$ July Julho $-31^{\text {TH }}$ December Dezembro $2018 \cdot$ pp. 160-164

DOI: https://doi.org/10.26619/2184-1845.XIX.2.10
\end{abstract}

A presente obra coletiva, realizada sob a coordenação de Davide Argiolas, Doutor em Direito Público pela Faculdade de Direito da Universidade de Coimbra e professor universitário, reúne artigos de juristas com destacada atividade profissional, seja acadêmico-investigativa ou prático-profissional, nas áreas da liberdade religiosa, risco e segurança.

Passo a destacar, de maneira não exaustiva, algumas das virtualidades da presente obra. Primeiro, trata-se de um trabalho relevante por sistematizar reflexões em torno do direito humano à liberdade religiosa, considerado por alguns como the first right, e o faz oportunamente no ano em que se celebram os 70 anos da Declaração Universal dos Direitos do Homem. Numa época em que as restrições à religião continuam a subir em todo o mundo (vide Relatórios do PEW Research Center), obras que tratam do livre exercício da religião ou crença revestem-se de singular importância.

Além disso, a obra tem o mérito de analisar a liberdade religiosa numa perspectiva transversal, isto é, relacionando-a com outros ramos do direito que não são usualmente afetos ao chamado "direito religioso", tais como o direito penal, direito fiscal e direito das migrações. Cumpre ressaltar, ainda, que os autores, por serem de nacionalidades diversas, nomeadamente de Portugal, Brasil, Espanha, Itália e Síria, enriquecem a obra ao trazerem perspectivas e lições observadas de seus próprios contextos, resultando num estudo multifacetado inclusive do ponto de vista geográfico.

Ainda, temos diante de nós um conteúdo que atende necessidades de ordem prática. Nesse sentido, considero que alguns fatos e fatores sociológico-político-jurídicos atuais demandam, como nunca antes, estudos que tratem das interconexões, limites e garantias que fluem dos direitos à liberdade religiosa $\mathrm{e}$ à segurança. Podemos citar, de maneira meramente exemplificativa, o ressurgimento global da religião na esfera pública - o que alguns chamam da "dessecularização do mundo" - e sua crescente influência política; o crescimento de grupos e ações terroristas de alcance 
internacional com alegadas motivações religiosas, que levanta preocupações quanto aos limites da autonomia das organizações religiosas; a realidade desoladora de desastres humanitários e conflitos que têm provocado um influxo em massa de migrantes com filiações religiosas próprias que, não raras vezes, diferem da cosmovisão majoritária do país de destino, o que leva a discussões complexas sobre a integração desses grupos, à luz dos princípios da diversidade e tolerância.

Esses são alguns dos temas tratados, com excelência, na obra em comento, razão pela qual, frise-se, temos diante de nós uma obra relevante, atual e necessária.

Diego Di Giuseppe e Francescadiletta Bortone nos apresentam uma radiografia da natureza, estrutura e funcionamento das atuais formas de terrorismo, com destaque para as transformações ocorridas ao longo do tempo, do "velho terrorismo" até chegar aos moldes atuais. Uma das facetas do "novo terrorismo" que o autor aborda é precisamente a "mistura da natureza política e religiosa dos ataques terroristas", que envolve uma sobreposição desses dois propósitos, algo não existente no passado.

Alejandro Torres Gutierrez, por seu turno, aborda o caráter "mercurial" do novo terrorismo de conotação islâmica, e destaca a necessidade de uma integração social, laboral e educativa da população migrante de origem muçulmana, estratégia capaz de prevenir o risco de radicalização e polarização social, sem prescindir, contudo, de mecanismos de inteligência, cooperação internacional e atua- ção policial capazes de, tais como fazemos com o mercúrio, "aspirá-lo com cuidado, uma vez localizado, misturá-lo com outros metais quando não puder ser aspirado, evaporá-lo de forma controlada e, finalmente, reciclá-lo".

Nessa mesma senda, Roberto Mazzola reflete em seu texto sobre qual modelo deve ser implementado na relação entre liberdade e segurança, em especial quando estamos a referir a um estado de emergência provocado por ações terroristas. O autor considera que, diante de um perigo público que ameaça a subsistência da nação, ainda que motivado moral ou religiosamente, a margem de discrição do Estado só será razoável e legítima se for justificada por razões sérias que demandam a proporcional salvaguarda das instituições.

Rodrigo Vitorino Souza Alves, por sua vez, busca apresentar um conjunto de parâmetros destinado a orientar a aplicação de medidas restritivas ao exercício da liberdade religiosa no contexto do contraterrorismo. Após analisar a proteção internacional da liberdade religiosa e a necessidade de respeito aos direitos humanos no combate ao terrorismo, o autor conclui que podem ser consideradas legítimas e necessárias interferências na autonomia das organizações religiosas e no exercício de direitos correlatos, como direito de reunião e associação para fins religiosos, com a finalidade de conter a incitação ou apologia ao terrorismo.

Jamil Ammar aborda a problemática do contraterrorismo e a comercialização do discurso de ódio religioso, através da análise de campanhas de propaganda wahhabi e salafi, 
à luz das normas de liberdade de expressão e legislações de combate ao terrorismo no Oriente Médio.

Joaquim Sabino Rogério busca contrapor as comuns associações feitas entre islamismo e terrorismo/violência, através de uma análise detida do significado, surgimento e estrutura do Islão e do direito islâmico, apresentando-nos em seguida interessantes reflexões no âmbito das possiblidades e limites da expressão religiosa no espaço público numa comunidade constitucional.

$\mathrm{O}$ artigo de Davide Argiolas aborda uma temática complexa e atual, que é a responsabilidade civil extracontratual das comunidades religiosas por abusos sexuais de menores perpetrados pelos ministros de culto. $\mathrm{O}$ autor busca responder, em suma, se seria legítimo impor uma reparação de danos à própria comunidade religiosa, sabendo que ela mesma é lesada pela atuação dos ministros de culto pedófilos, e, assumindo-se uma resposta afirmativa, em que moldes deve-se processar a responsabilidade, isto é, de maneira subjetiva ou objetiva, e os impactos que uma ou outra abordagem poderá ter sobre as liberdades individuais e coletivas.

Jónatas Machado e Paulo Nogueira da Costa exploram o regime jurídico-tributário da doação de imóveis para fins religiosos, e, nessa seara, defendem que os benefícios fiscais concedidos às confissões religiosas, incluindo a isenção fiscal das pessoas coletivas religiosas pela aquisição de bens para fins religiosos, não podem ser entendidos como subsídios concedidos à margem do princípio da separação das confissões religiosas do Estado. Antes, trata-se do "reconhecimento - fundado nos valores da dignidade da pessoa humana, do livre desenvolvimento da personalidade e dos direitos e da autonomia individual e coletiva - de que a promoção das dimensões imateriais, morais, sociais e não económicas da existência humana deve estar excluída a priori da base tributária".

O artigo de Uziel Santana analisa uma legislação específica, a Nova Lei de Migrações do Brasil, e traz uma importante reflexão acerca de suas implicações à proteção da liberdade religiosa, em comparação com o regime jurídico anterior, regulado pelo chamado Estatuto do Estrangeiro. $\mathrm{O}$ autor destaca o novo paradigma de proteção aos migrantes forçados que a nova lei inaugura, fundamentado nos direitos humanos, não apenas na segurança nacional, e aponta a criação do visto temporário para acolhida humanitária como um instrumento apto a maximizar a proteção de vítimas de altas restrições em virtude da religião ou crença.

Diante do exposto, resta-nos recomendar a leitura da presente obra, por apresentar insumos valiosos na busca de soluções que sejam capazes de combinar liberdade econômica, política, religiosa e cultural com a sempre imperiosa demanda por segurança pública.

\section{FELIPE AUGUSTO LOPES CARVALHO}

Mestre - Universidade de Coimbra 
